\section{STEREOSELECTIVE SYNTHESES AND}

SELF-ASSEMBLING CAPABILITIES OF

HETEROCYCLIC CINNAMIC ACIDS

Csankó Krisztián

Supervisor: Dr. Pálinkó István

Co-supervisor: Dr. Sipos Pál

Doctoral School of Chemistry

Department of Organic Chemistry

Faculty of Science and Informatics

University of Szeged

Szeged, Hungary

2015
PhD

Dissertation 
This dissertation is available online at Library of University of Szeged:

http://doktori.bibl.u-szeged.hu/cgi/search/advanced

\section{Recommended Citation:}

K. Csankó, "Stereoselective syntheses and self-assembling capabilities of heterocyclic cinnamic acids", PhD Thesis, University of Szeged, 2014. 


\section{TABLE OF CONTENTS}

List of abbreviations. VII

1. Introduction 1

2. Literature Overview. 2

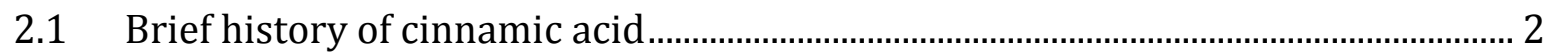

2.1.1 The relation of cinnamic acid and cinnamon ................................................... 2

2.1.2 Discovery and the first synthesis of cinnamic acid............................................ 3

2.1.3 First applications of cinnamic acid and its derivatives ...................................... 4

2.2 Natural occurrence and the synthesis of cinnamic acid and its derivatives .......... 6

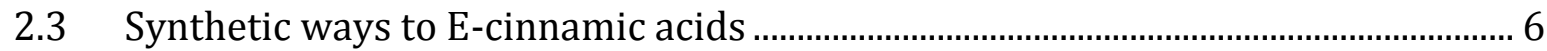

2.3.1 The Perkin condensation reaction ......................................................................... 6

2.3.2 The Claisen-Schmidt condensation reaction...................................................... 7

2.3.3 The Knövenagel-Döbner condensation reaction .................................................. 7

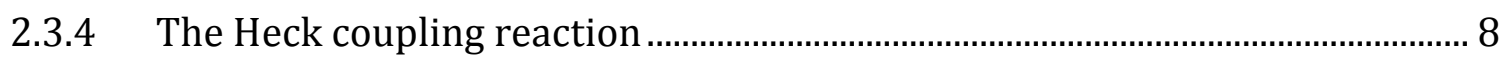

2.3.5 Microwave-assisted synthesis of cinnamic acid derivatives ............................. 9

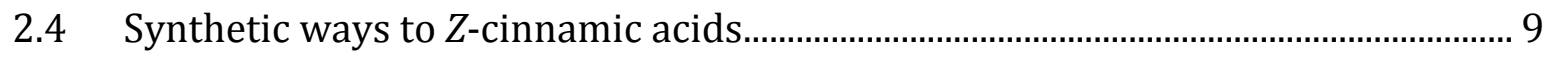

2.4.1 Photoinduced isomerization of E-cinnamic acids................................................ 9

2.4.2 Z-selective catalytic hydrogenation of alkynes ................................................. 10

2.4.3 The Horner-Wadsworth-Emmons (HWE) olefination .......................................11

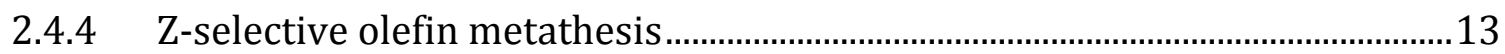

2.5 Synthetic ways to $\alpha$-substituted cinnamic acids ..................................................... 13

2.5.1 The modified Perkin and other relevant condensations...................................13

2.5.2 Synthesis of $\alpha$-substituted cinnamic acids via addition reactions...................14

2.6 Secondary chemical bonds and the self-assembling capabilities of cinnamic acids 15 
2.6.1 About secondary chemical bonds......................................................................

2.6.2 Possible interactions between cinnamic acids....................................................16

2.6.3 Self-assembling of various molecules over transition metal surfaces ...........19

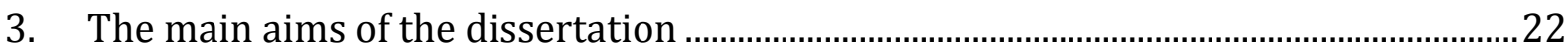

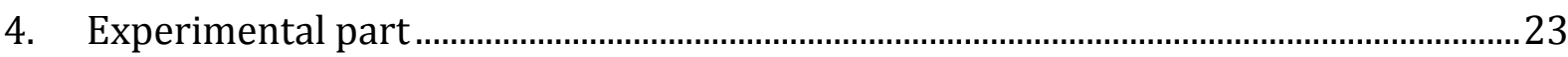

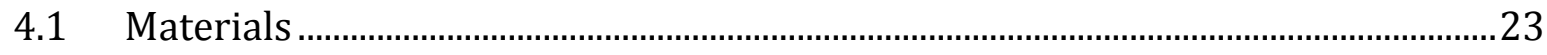

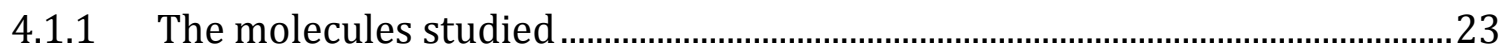

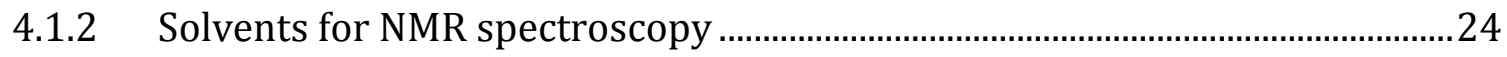

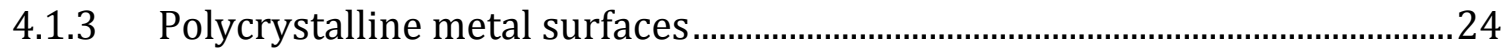

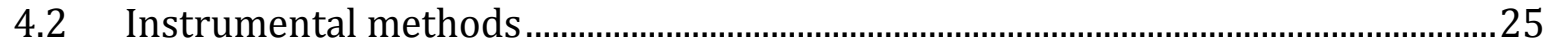

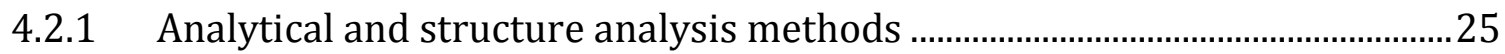

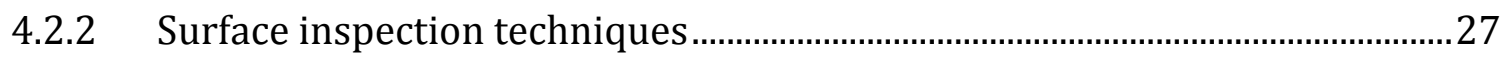

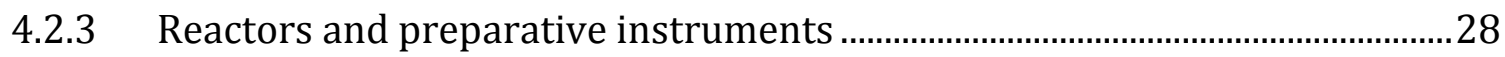

4.3 General methods for the stereoselective synthesis of $E$-cinnamic acids ..............29

4.3.1 Preparation of 2-selenophenylcarboxaldehyde with Vilsmeier-Haack formylation 29

4.3.2 Preparation of E-cinnamic acid with the Perkin condensation .........................30

4.3.3 Preparation of E-ethylcinnamate with the Claisen-Schmidt condensation.30

4.3.4 Preparation of diethyl-2-benzylidene malonate with the Knövenagel condensation

4.3.5 Microwave-assisted Knövenagel-Döbner condensation procedures..............31

4.3.6 Preparation of E-cinnamic acid with the Knövenagel-Döbner condensation 32

4.3.7 Preparation of E-3-(2 or 3-furyl-, 2 or 3-thienyl-, 2, 3 or 4-pyridyl- and 2selenophenyl)propenoic acids with the Knövenagel-Döbner condensation 32

4.3.8 Solubilities of cinnamic acid derivatives in DMSO ...............................................33 
4.3.9 Preparation of octyl-E-3-(2-thienyl)propenoate and octyl-E-3-(3thienyl)propenoate

4.4 General methods for the synthesis of $E$-Z-cinnamic acid isomer mixtures 35

4.4.1 Preparation of E-Z cinnamic acid isomer mixtures via UV induced photoisomeriza-tion and the kinetics of the process. 35

4.5 General methods for the stereoselective synthesis of $Z$-cinnamic acids 36

4.5.1 Preparation of 3-phenylpropiolic acid and methyl 3-phenylpropiolate........36

4.5.2 Z-selective hydrogenation of 3-phenylpropiolic acid with Lindlar's catalyst 37

4.5.3 Utilizing the HWE synthesis for Z-selective preparation 39

4.5.4 Preparation of the different HWE phosphonates

4.5.5 Optimization of the Z-selective HWE reaction with Still-Gennari and Andotype phosphonates. 41

4.6 Synthesis of the $\alpha$-substituted cinnamic acid derivatives 44

4.6.1 The synthesis of E-Z-3-phenyl-2-(3-pyridyl)propenoic acid via the modified Perkin condensation 45

4.6.2 The synthesis of E-2-phenyl-3-(3-pyridyl)propenoic acid via the HWE method 46

4.7 Computational chemistry part: software and methods 47

4.7.1 Official software packages

4.7.2 Creating software for conformational analysis (Quantum Hyppo and Izzy Reader) 47

4.7.3 The applied quantum chemical methods 51

5. Results and Discussion

5.1 Summary of the synthetic part...

5.1.1 The results of the E-selective methods

5.1.2 Photoisomerization of E-cinnamic acids 56 
5.1.3 Summary of the Z-selective methods

5.1.4 Summary of the synthetic methods for $\alpha$-substituted cinnamic acid derivatives. . .58

5.2 Determining the different hydrogen bonds with infrared spectroscopy 58

$5.3{ }^{1} \mathrm{H}-{ }^{1} \mathrm{H}$ correlation (COSY) and nuclear Overhauser effect (NOESY) NMR spectra of heteroaryl cinnamic acids

5.4 Identifying the $\pi$-stacking interactions with powder X-ray diffractometry.........75

5.5 Self-assembling of the studied molecules over polycrystalline gold and silver surfaces

5.6 Computational results . .83

5.6.1 Conformational analysis . .83

5.6.2 Hydrogen-bonded dimers .87

5.6.3 Hydrogen-bonded tetramers and other structures 91

5.6.1 П-stacking interactions 94

Summary 96

Related Publications. A

Other Publications. B

References. C

Magyar nyelvű összefoglaló (Hungarian summary) .......................................................... ACKNOWLEDGEMENT L

Appendix M 


\section{LIST OF ABBREVIATIONS}

\section{MATERIALS}

General method for the naming of the studied cinnamic acids:<smiles>O=C(O)I=Nc1cccnc1</smiles>

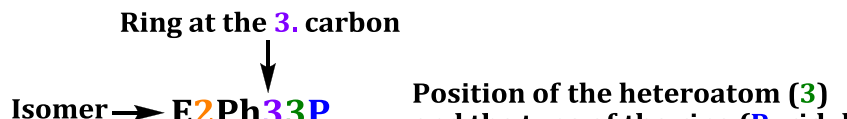

Phenyl ring at the 2 . carbon

E2Ph33P = E-2-phenyl-3-(3-pyridyl)propenoic acid

$\mathbf{P h}=$<smiles>c1ccccc1</smiles><smiles>[PH3]=[Ni]</smiles>

$\mathbf{F}=$<smiles>c1ccoc1</smiles>

$\mathrm{T}=$<smiles></smiles>

$S=$<smiles>c1cc[se]c1</smiles>

A few examples for the shortened names:

E3Ph - cinnamic acid (E-3-phenylpropenoic acid (1/E))

E32F - E-3-(2-furyl)propenoic acid

E32T - E-3-(2-thienyl)propenoic acid

E32S - E-3-(2-selenienyl)propenoic acid

E33P - E-3-(3-pyridyl)propenoic acid

E23T33T - E-2-(3-thienyl)-3-(3-thienyl)propenoic acid

Z2Ph33P - Z-2-phenyl-3-(3-pyridyl)propenoic acid

$\mathbf{Z}$ - "Z" instead of "E" before the shorthand names of the materials listed above, means the $Z$ isomer

M - at the end of the shorthand names of the materials listed above, means the individual monomer

D - at the end of the shorthand names of the materials listed above, means the dimer kept together by double hydrogen bonds between the carboxylic groups

$\mathbf{T}$ - at the end of the shorthand names of the materials listed above, means the tetramer built up from two dimers via (aromatic) $\mathrm{C}-\mathrm{H}$...X hydrogen bond between the aromatic rings

Me - at the end of the shorthand names of the materials listed above, means the methyl ester of the corresponding cinnamic acid derivative

$\mathbf{0}$ - at the end of the shorthand names of the materials listed above, means the octylester of the corresponding cinnamic acid derivative

ZW - at the end of the shorthand names of the materials listed above, means that the pyridyl derivatives are in the zwitterionic forms

EWG - electron withdrawing group 
Ar - aromatic group

$\mathbf{P h}$ - phenyl group

$\mathbf{R}$ - substituent

$\mathbf{X}$ - heteroatom $(\mathrm{O}, \mathrm{N}, \mathrm{S})$

Hlg - halogen $(\mathrm{F}, \mathrm{Cl}, \mathrm{Br}, \mathrm{I})$

Ac - acetyl group

Me - methyl group

Et - ethyl group

Pr - propyl group

MeO - methoxy group

EtO - ethoxy group

TEA - triethylamine

THF - tetrahydrofuran

DMSO - dimethyl sulfoxide

DMF - N,N-dimethylformamide

MeOH - methanol

EtOH - ethanol

$\mathbf{A c O H}$ - acetic acid

EtOAc - ethyl acetate

$\mathbf{A c}_{2} \mathbf{O}$ - acetic anhydride

KHMDS - potassium bis(trimethylsilyl)amide

$\boldsymbol{t}$-BuOK - potassium tert-butoxide

DMAP - 4-(dimethylamino)pyridine

PPE - polyphosphate ester

TBAB - tetrabutylammonium bromide

TMS - tetramethylsilane

TMSO - trimethylsilyloxy group

DSS - 4,4-dimethyl-4-silapentane-1-sulphonic acid

\section{METHODS}

MALDI-MS - matrix-assisted laser desorption/ionization mass spectrometry

(M)IR - mid-range infrared spectroscopy 
MCT - mercury cadmium telluride detector

DTGS - deuterated triglycine sulfate

ATR-IR - attenuated total reflection infrared spectroscopy

UV-Vis - ultraviolet-visible spectroscopy

NMR - nuclear magnetic resonance spectroscopy

COSY - nuclear magnetic resonance correlation spectroscopy

NOESY - nuclear Overhauser effect spectroscopy

HSQC - heteronuclear single quantum coherence spectroscopy

XRD - X-ray diffractometry

IRM - infrared microspectroscopy

SEM - scanning electron microscopy

AFM - atomic force microscopy

GC - gas chromatography

FID - flame ionization detector

HPLC - high pressure liquid chromatography

PLD - pulsed laser deposition

MW - microwave irradiation

UV - ultraviolet irradiation

hv - irradiation with light

US - ultrasound irradiation

SAM - self-assembled monolayer

LbL - layer-by-layer

HWE - Horner-Wadsworth-Emmons

OBF - one bond flip

ROCM - ring opening cross-metathesis

UWFP - used without further purification

OTHER

*- indicates data from own measurements

rbf. - round bottomed flask

cat. - catalytic amount/catalyst

sicc. - water-free compound 
cc. - concentrated

r.t. - room temperature

mp. - melting point

Mr. - relative molecular mass

$\mathbf{R}_{\mathbf{f}}$ - retention factor

eq. - equivalent

quant. - quantitative

M - concentration in $\mathrm{mol} / \mathrm{dm}^{3}(\mathrm{c})$

$\mathbf{K}$ - equilibrium constant

$\mathbf{k}$ - forward rate constant

$\mathbf{k}_{\mathbf{b}}$ - backward rate constant

$\boldsymbol{\varepsilon}$ - molar extinction coefficient $\left(\mathrm{M}^{-1} \mathrm{~cm}^{-1}\right)$

$\lambda$ - wavelength

$\Delta$ - heating/elevated temperature

MCU - microcontroller unit

AVR - advanced virtual RISC (Reduced Instruction Set Computing) by Atmel co.

ISP - in system programmer

USB - universal serial bus

MOSFET - metal oxide semiconductor field-effect transistor

CPU - central processing unit (processor)

E - energy of the optimized molecular framework (Joule, kJoule $/ \mathrm{mol}, \mathrm{kcal} / \mathrm{mol}$ )

BSSE - basis set superposition error

RMS - root mean squared gradient

CP - counterpoise method

He - energy in Hartree

$\mathbf{D}^{\circ}$ - dihedral angle

ZPE - zero-point energy

HF - Hartree-Fock level

DFT - density functional theory

B3LYP - Becke three-parameter Lee-Yang-Parr method

CBSB7 - covers the 6-311G(2d,d,p) basis set

PM(3,6) - parameterized model number 3 or 6 method 
MP2 - Møller-Plesset's second perturbation theory

WB97XD - Head-Gordon type Becke function with empirical dispersion

ABBREVIATIONS OF THE NMR SPECTRA

$\mathbf{v}$ - frequency $(\mathrm{Hz})$

$J$ - coupling constant $(\mathrm{Hz})$

$\boldsymbol{\delta}$ - chemical shift (ppm)

ppm - parts per million

s - singlet

d - doublet

$\mathbf{t}$ - triplet

q-quartet

quint. - quintet

m - multiplet

dd -doublet of doublets

$\mathbf{d t}$ - doublet of triplets

td - triplet of doublets

br - broad signal 
„Some scientists claim that hydrogen, because it is so plentiful, is the basic building block of the universe. I dispute that. I say that stupidity is far more abundant than hydrogen, and that is the basic building block of the universe."

Frank Zappa 


\section{INTRODUCTION}

Cinnamic acid (E-3-phenylpropenoic acid, 1/E) is a well-known material, because it can be found in cinnamon, which was mentioned for the first time on ancient Egyptian hieroglyphs (2000 B.C) $)^{2}$. The oil of leafs and the bark of Cinnamomum Verum (cinnamon plants are native in Sri Lanka) contains cinnamaldehyde (2) as a main component (50-80\%) and several percent of esters and terpenes. ${ }^{3}$ Cinnamon (the bark of the plant) and the oil of the leafs have been widely used as flavor and food preservative ${ }^{4}$ as well for thousands of years, because some of its components, mostly the cinnamic acid derivatives, have antimicrobial effect on pathogenic bacteria ${ }^{5}$ and on human diseases like upper respiratory tract infection caused by Pneumococcus. As it was mentioned, cinnamic acid can be found in cinnamon, due to the slow oxidation of cinnamaldehyde (2) to the more stable E-cinnamic acid $(\mathbf{1} / \mathbf{E})$ on contacting with air. ${ }^{6}$

Cinnamic acid (1/E) was synthesized first by W.H. Perkin ${ }^{7}$ in 1868 but, its use and those of its derivatives were delayed until the second world war, where the first UVprotective sunscreen was prepared from cinnamate esters ${ }^{8}$ for the soldiers fighting in the Pacific area. The second "big boom" in the history of cinnamic acid, came at the late 80 's, when they gained importance as sample matrices in the MALDI-MS technique ${ }^{9}$ due to its high absorbance in the UV range (the average molar extinction coefficient is around: $19556 \mathrm{M}^{-1} \mathrm{~cm}^{-1}$ ).

The substituted derivatives of cinnamic acids and some heteroatom-containing derivatives came into the focus of our research group, since they proved to be good models for studying hydrogen bonding driven assembling in solutions as well as in the solid state. ${ }^{10,11,12,13,14}$ It was found that they were capable short- and long-range ordering in solution and the solid state, respectively. The fundamental units were found to be the dimers, kept together by strong hydrogen bonds, while the multimers of the dimers interacting with weaker (aromatic)C-H...X (where X = O, N, S) close contacts.

In most of these studies, the combination of spectroscopic methods and molecular modelling was applied for the characterization of the structure-forming interactions. 


\section{LITERATURE OVERVIEW}

\subsection{Brief history of cinnamic acid}

\subsubsection{The relation of cinnamic acid and cinnamon}

Cinnamic acid (Figure 1) $\mathbf{1 / E}$ (and its derivatives) is one of the several substances that we widely use in our everyday life without the recognition of its presence.

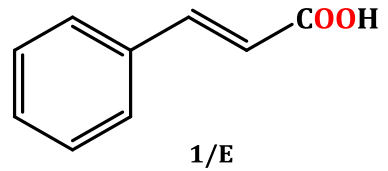

Figure 1 The structure of E-cinnamic acid (E-3-phenylpropenoic acid, 1/E)

Cinnamic acid, or E-3-phenylpropenoic acid 1/E, is a white crystalline material with honey-like odor. It has a completely planar structure, due to the continuous conjugation along the molecular framework. ${ }^{15}$ It appears in many plants over the world (e.g., Liquidambar orientalis ${ }^{16}$, Vitellaria paradoxa ${ }^{17}$, Petroselinum tuberosum $^{18}$ ), but the most important sources are the various types of cinnamons. Cinnamon is one of the oldest spices we use. It has very pleasant smell and taste, and has beneficial effect on digestion and health, too. There are many different theories about the first mention of cinnamon in written history, because of the confusion around the four general types of cinnamon plants in the Lauraceae family ${ }^{19}$, which has worldwide distribution in tropical and warm climates: 
- Cassia, or "wild cinnamon" the bark of Cinnamomum Iners tree, can be found in Ethiopia and Singapore ${ }^{19}$,

- Malabathrum, the grounded leafs of Cinnamomum Tamala, which is native in India and China ${ }^{20}$,

- Serichatum, the aromatic bark of Cinnamomum Cassia, widely cultivated in China, Laos, Malaysia and Vietnam ${ }^{20}$,

- And the "true cinnamon" is the inner bark of the Cinnamomum Verum plant

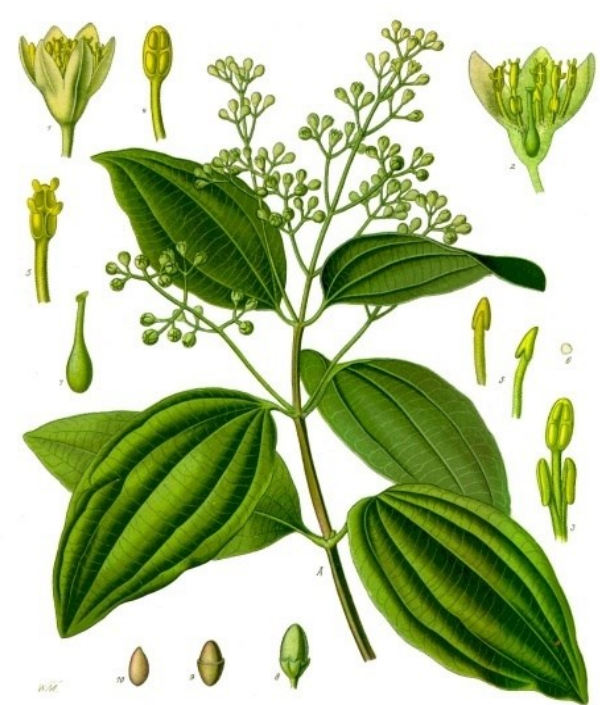

Figure 2 The Cinnamomum verum plant ${ }^{1}$ (Figure 2).

The oil of the Cinnamomum verum bark contains many compounds, such as cinnamaldehyde 2 in more than 50\%, E-ethyl cinnamate 3, R-(-)-linalool 4, eugenol 5, estragole 6 and several terpenes ${ }^{3}$ (Figure 3).<smiles>O=C/C=C/c1ccccc1</smiles><smiles>CCOC(=O)/C=C/c1ccccc1</smiles><smiles>C=C[C@](C)(O)CCC=C(C)C</smiles><smiles>C=CCc1ccc(O)c(OC)c1</smiles><smiles>C=CCc1ccc(OC)cc1</smiles>

4

Figure 3 Main components of cinnamon essential oil

\subsubsection{Discovery and the first synthesis of cinnamic acid}

Despite the high concentration of cinnamaldehyde $\mathbf{2}$ in the essential oil, it was isolated quite late, in 1834 by Dumas and Préligot ${ }^{21}$; then, it was first synthesized in 1854 by Chiozza ${ }^{22}$, via the aldol condensation of benzaldehyde 7 and acetaldehyde. Cinnamaldehyde $\mathbf{2}$ is slowly oxidized ${ }^{6}$ to cinnamic acid $\mathbf{1}$ /E on contact with air; thus, the essential oil of cinnamon will contain significant amount of cinnamic acid 1/E after ageing. In spite of this, cinnamic acid 1/E was not discovered through isolation from cinnamon oils. It was first synthesized in 1868 by Perkin ${ }^{7}$, who discovered the 
condensation reaction between acetic anhydride $\mathbf{8}$ and aromatic aldehydes, such as salicylaldehyde $\mathbf{9}$ giving o-coumaric acid $\mathbf{1 0}$ that can be transformed to coumarine $\mathbf{1 1}$ (via intramolecular esterification) or benzaldehyde $\mathbf{7}$ giving cinnamic acid $\mathbf{1} / \mathbf{E}$ in the presence of the potassium, or sodium salt of the corresponding acid (acetic acid) (Figure 4). However, the importance of cinnamic acid $\mathbf{1 / E}$ was smaller than that of coumarine $\mathbf{1 1}$ in those days. Coumarine was an important substance in the perfume industry, it was the first synthetic perfume in history. ${ }^{7}$

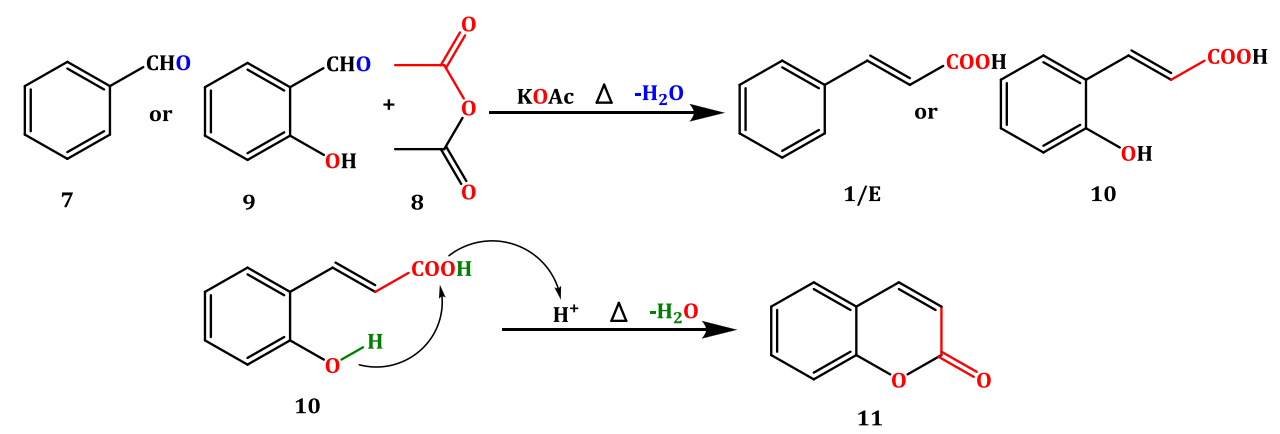

Figure 4 The Perkin condensation reactions

\subsubsection{First applications of cinnamic acid and its derivatives}

The first mention about the application of cinnamic acid itself, was delayed to 1946, when the Swiss chemist Franz Greiter introduced the first modern sunscreen called "Gletscher Créme"8 that contained etylhexylmetoxycinnamate 12 (Figure 5).

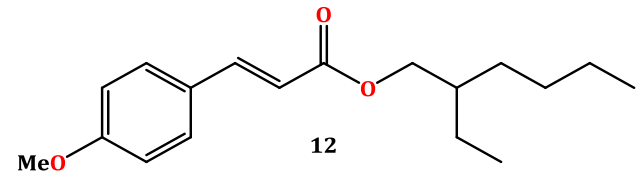

Figure 5 The structure of (RS)-2-ethylhexyl (2E)-3-(4-methoxyphenyl)propenoate (12)

It is the main component $(10-20 \%)$ of sunscreens up to now, due to its wide absorption band in the UV B/C range $(260-315 \mathrm{~nm})^{23}$ and the high molar absorption coefficient $\left(\varepsilon={ }^{*} 19556 \mathrm{M}^{-1} \mathrm{~cm}^{-1}\right.$ for E-cinnamic acid 1/E and ${ }^{*} 24160 \mathrm{M}^{-1} \mathrm{~cm}^{-1}$ for E-ethyl cinnamate 3). After the "big boom" on the market of sunscreens, the developers needed a more efficient way to synthesize cinnamic acids than the old Perkin condensation, which performs well (yield 85-93\%) in the laboratory, but the scalability is poor. In 1951 J. Blake et al. ${ }^{24}$ published a very general method, based on the Knövenagel-Döbner 
condensation ${ }^{7}$, which can be used for the quick and efficient synthesis of a variety of cinnamic acid derivatives.

In the second half of the $20^{\text {th }}$ century, the direct use of cinnamic acid in cosmetics started to grow very fast, and it became a basic material in the production of fine fragrances, decorative cosmetics, shampoos, toilet soaps or even in household chemicals, such as cleaners and other detergents. ${ }^{25}$

The next evolutionary step for cinnamic acids was the invention of the matrixassisted laser desorption mass spectrometry (MALDI-MS) in 1985 by Franz Hillenkamp ${ }^{26}$ and his postdoc. They found that amino acids, even proteins and other large molecules can be ionized more easily with UV light, when they were mixed with conjugated aromatic compounds like cinnamic acid derivatives, because then, they had a wide absorption band in the UV range. ${ }^{27,28,29}$ Due to this ability, if they irradiated with a high intensity UV laser in the 254-360 nm range, they vaporize and form ions. From the early 90's several cinnamic acid derivatives were tested as sample matrices in different MALDI setups and substances like proteins, polynucleotides, lipids, etc. Nowadays, the MALDI technique uses many cinnamic acid derivatives ${ }^{9}$, the most important ones are: caffeic 13, sinapinic 14, ferulic 15 and $\alpha$-cyano-4-hydroxycinnamic acids ${ }^{30}$ 16, listed in Figure 6.
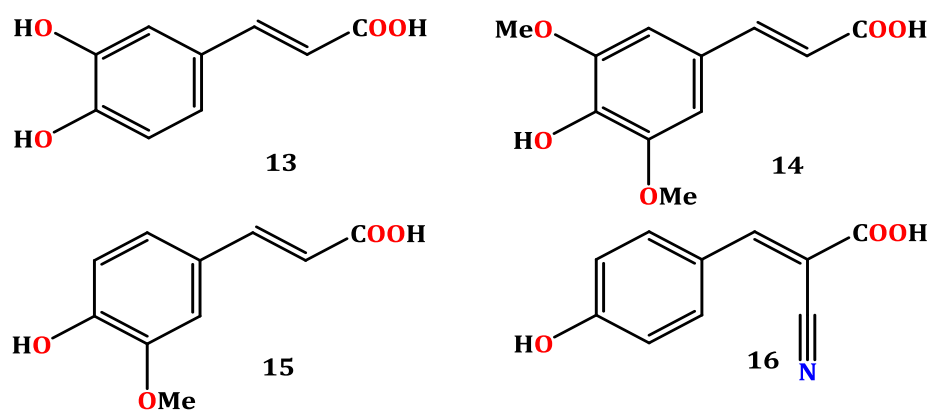

Figure 6 Cinnamic acid derivatives used as general sample matrices in MALDI

During the last 20 years cinnamic acid and its derivatives entered the spotlight again. Several pharmacological studies were carried out. Besides, the structure-forming properties were studied by some researchers as well. 
The worldwide production of cinnamic acid is in the range 9-10 tons per annum, well indicating the importance of this compound. ${ }^{4}$

\subsection{Natural occurrence and the synthesis of cinnamic acid and its derivatives}

Cinnamic acid $\mathbf{1 / E}$ and cinnamates are present in many plants, as has been mentioned above, as members of the shikimate ${ }^{31}$ metabolism (it is a mayor pathway in the synthesis of aromatic amino acids) and the phenylpropanoid biosynthetic pathway.

\subsection{Synthetic ways to E-cinnamic acids}

As it has been mentioned previously, there are several different synthetic methods for producing cinnamic acid 1/E; however, all of the listed reactions lead to the thermodynamically more stable $E$ isomer. The most important synthetic methods for the preparation of E-3-phenylpropenoic acid 1/E are communicated in the followings.

\subsubsection{The Perkin condensation reaction}

As it has been mentioned before, this reaction takes place between aromatic aldehydes $\mathbf{7}$ and acetic anhydride $\mathbf{8}$, in the presence of the potassium or sodium salt of the corresponding organic acid (many other bases can catalyze the reaction, like carbonates, phosphates, sulfides, organic amines and even sodium or potassium metals). ${ }^{32,33,34}$ A possible mechanism is shown in Figure 7.

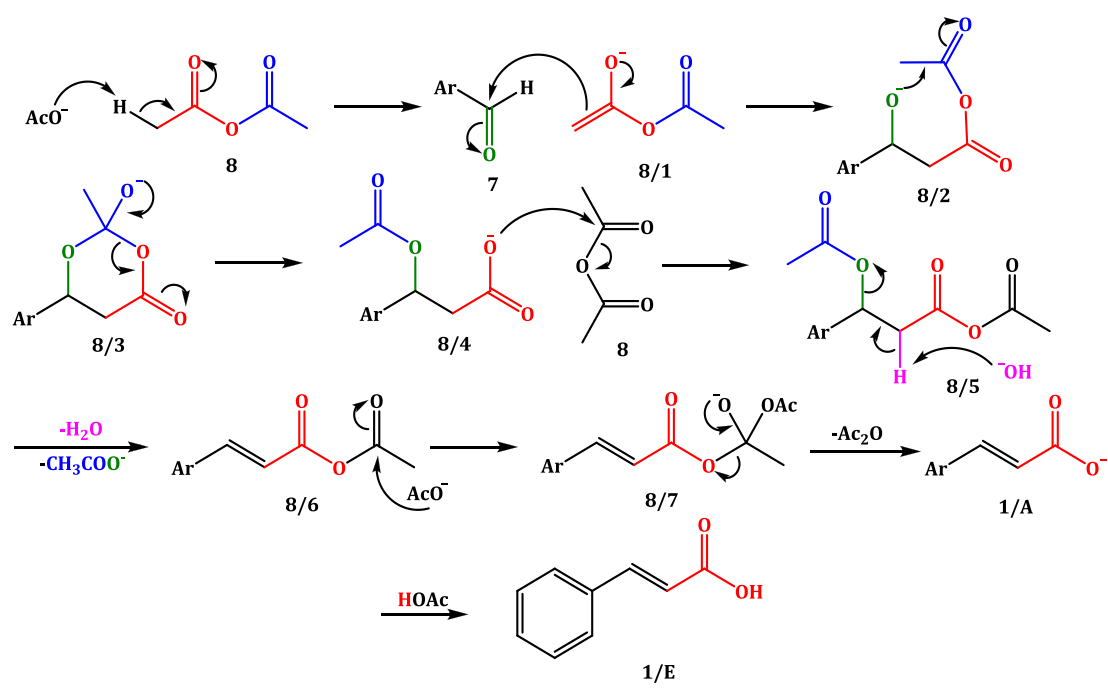

Figure 7 A possible mechanism of the original Perkin condensation ${ }^{35}$

The modified version of the Perkin reaction can be used for the synthesis of $\alpha$ substituted cinnamic acid derivatives, where acetic anhydride $\mathbf{8}$ is the solvent and a 
reactant at the same time, reacting with acetic acid derivatives (phenylacetic acid 17) and usually amine bases is applied instead of inorganic salts. ${ }^{36}$ The preparation of $E-2$ phenylcinnamic acid $\mathbf{1 8}$ (E2Ph3Ph) is shown in Figure 8.

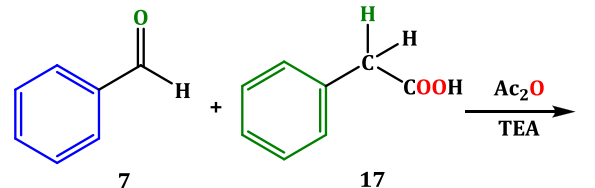

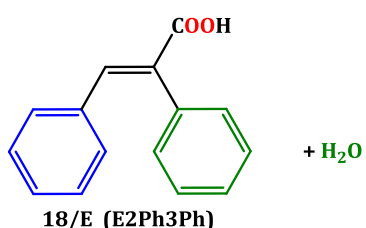

18/E (E2Ph3Ph)

Figure 8 The modified Perkin condensation

The main disadvantage of the Perkin reaction is the formation of resin-like side products for heterocyclic aldehydes, and the low yield, when the aromatic aldehyde contains one or more electron donor groups.

\subsubsection{The Claisen-Schmidt condensation reaction}

The Claisen-Schmidt condensation ${ }^{37,38}$ is a cross-aldol reaction taking place between several types of aldehydes/ketones and carbonyl compounds like esters in the presence of a strong base like sodium.

The formed methyl cinnamate can be converted to the acid with ester hydrolysis under alkaline conditions, followed by the addition of a strong acid (e.g. $\mathrm{HCl}$ ). The overall yield is more than $90 \%$ for several aromatic aldehydes.

\subsubsection{The Knövenagel-Döbner condensation reaction}

One of the most effective synthetic methods, which can lead to cinnamic acids $\mathbf{1 / E}$, is the Knövenagel condensation ${ }^{39}$ or "malonester synthesis" and its modified version, which is developed by Döbner. ${ }^{40}$ The Knövenagel condensation works with esters (Figure 9) ${ }^{41}$ e.g. diethyl malonate 19, which loses an $\alpha$ hydrogen and forms a carbanion 19/1 in the presence of piperidine $\mathbf{2 0}$, acting as the base, yielding diethyl-benzylidene malonate 21. The most problematic part of this reaction is the heat treatment, at least $135-150^{\circ} \mathrm{C}$ is needed for the complete decarboxylation. ${ }^{24,42}$ 

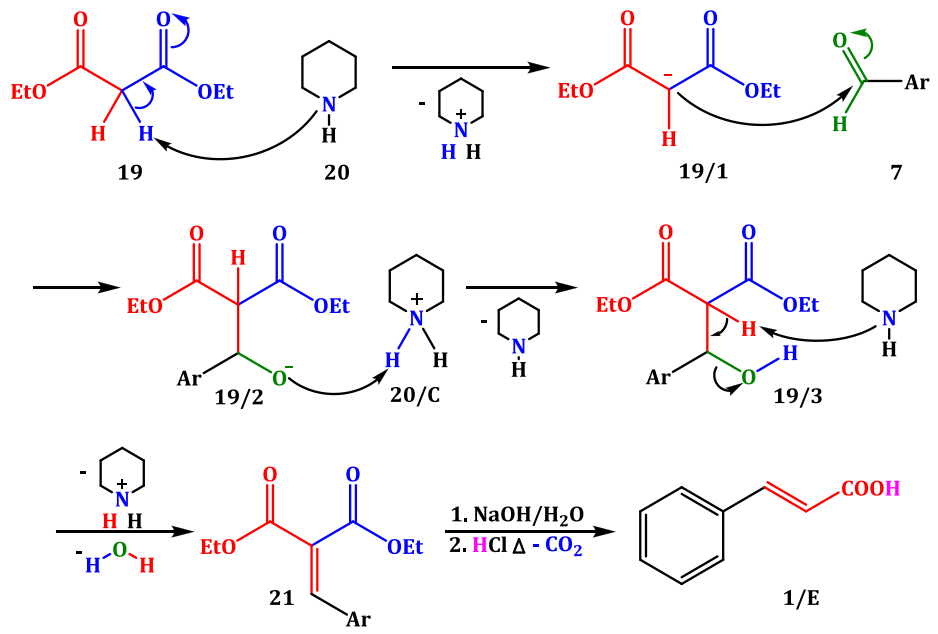

Figure 9 The mechanism of the Knövenagel condensation between diethyl malonate (46) and benzaldehyde

With the Döbner ${ }^{40}$ modification, cinnamic acid $\mathbf{1 / E}$ can be synthesized directly from malonic acid 22, dissolved in pyridine 43, where the dehydration and the decarboxylation steps from $\mathbf{2 4}$, can be carried out simultaneously in one pot, applying two temperatures during the synthesis. The catalyst in the Döbner variant is piperidine

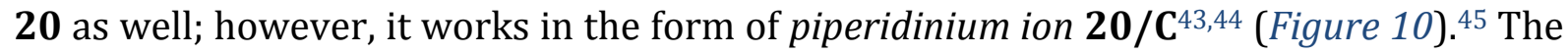
advantage of this reaction is the very high yield (in most cases 90-100\%).

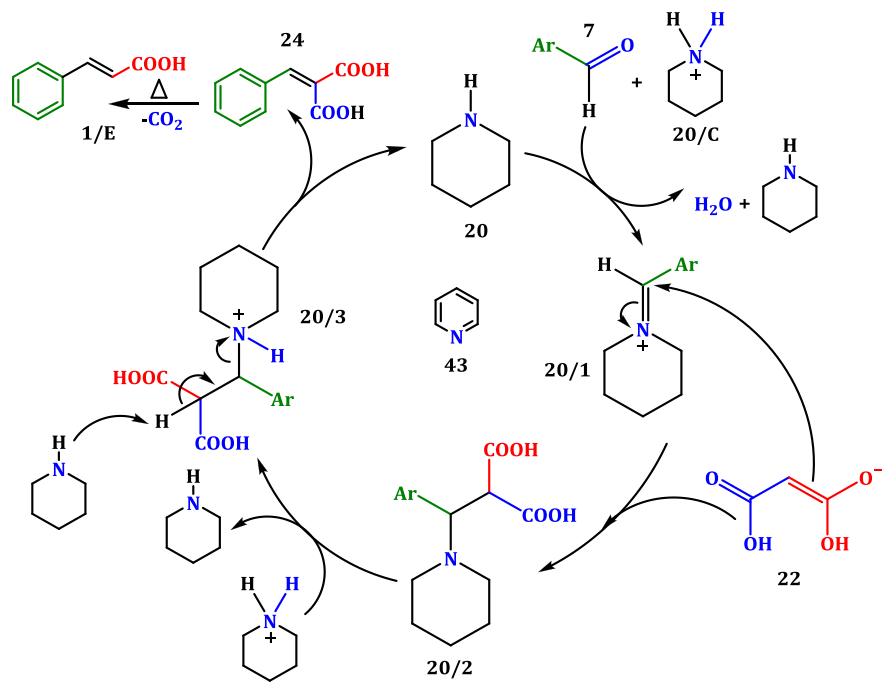

Figure 10 The catalytic cycle of piperidine (47) in the Knövenagel-Döbner condensation

\subsubsection{The Heck coupling reaction}

The so-called Heck coupling reaction (or Heck-Mizoroki reaction) ${ }^{46,47}$ takes place between alkyl or aryl halides and olefins in the presence of palladium-organophosphorous complexes and a base. The alkene has to contain at least one hydrogen and 
it performs better, if it contains EWG, e.g., esters like methyl acrylate, yielding cinnamoyl esters.

\subsubsection{Microwave-assisted synthesis of cinnamic acid derivatives}

The importance of microwave-assisted syntheses is growing very fast nowadays, due to the benefits of the method like higher yields, significantly shorter reaction time (1-30 $\mathrm{min})$, and the solvent-free conditions in some cases, due to the "superheating" effect. ${ }^{48}$ Most of the synthetic methods leading to cinnamic acid derivatives, mentioned earlier, can be carried out under microwave conditions (2.45 GHz), like the Döbner condensation in water with phase transfer catalyst or in the presence of PPE under solvent-free conditions. ${ }^{49,50}$

\subsection{Synthetic ways to $Z$-cinnamic acids}

As it has been shown on several examples above, the thermodynamically stable $E$ cinnamic acid derivatives can be easily achieved through various methods. With some modifications, one can shift the isomeric ratio towards the less stable Z-cinnamic acid isomer; however, the synthesis of the clean $Z$ isomers is more complicated. A few general examples are listed in the followings.

\subsubsection{Photoinduced isomerization of E-cinnamic acids}

Molecules with conjugated electronic system (like 1/E) can be excited with UV photons. The excited molecule becomes very reactive, but it can be relaxed in nonchemical ways like visible photon emission (fluorescence or phosphorescence) or trigger thermal reactions. However, the quantum efficiency is around only 0.2 in most of the organic reactions. On the other hand, in most cases, the excited molecule starts chemical reactions like rearrangement by isomerization, which is a useful tool to produce Z-cinnamic acids from the more easily available $E$ isomers.

The isomerization of E cinnamic acid 1/E (Figure 11) takes place without bond cleavage via a one-bond flip (OBF) around the double bond (diabatic photochemical reactions $)^{51}$, where the rotational barrier is in the $50-60 \mathrm{kcal} / \mathrm{mol}$ range; thus, the UV light (e.g., at $254 \mathrm{~nm}$ ) has enough energy to induce the isomerization $(112 \mathrm{kcal} / \mathrm{mol}) .^{52}$ 


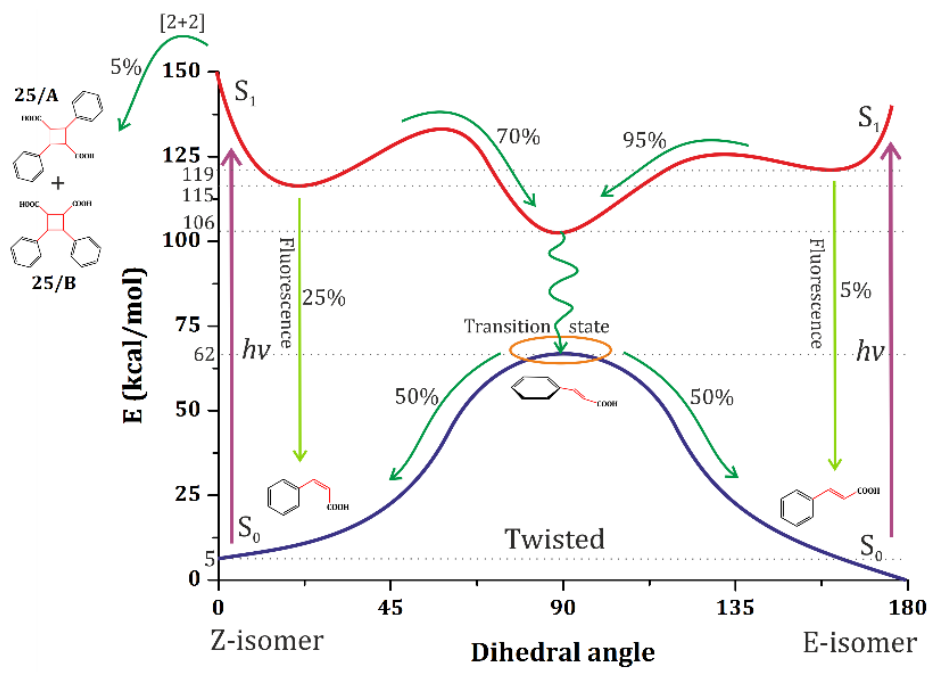

Figure 11 Estimated potential energy surface of the photoinduced processes with $E$-Z cinnamic acids in the UV range (based on stilbene 47 )

Both $E$ and $Z$ isomers have a wide absorption band in the UV range; thus, when they are irradiated with a mercury lamp (254 $\mathrm{nm}$ emission maximum) an $\mathrm{S}_{0} \rightarrow \mathrm{S}_{1}$ transition takes place, where the excited molecule can freely rotate around the double bond. There are two main possible ways to return to the ground state: the fluorescent way and the non-radiative relaxation. As one can see, the non-radiative way (green wavy arrow) is more frequent, and one gets even amounts of the isomers due to statistical consideration; however, the experimental data show a different result. The probability of the different types of relaxations is not equal; thus, one gets different isomer distribution: for cinnamic acid 1/E, 75:25, Z:E ratio was found after $72 \mathrm{~h}$ irradiation at $254 \mathrm{~nm} .{ }^{52,53}$ On the other hand, at higher concentrations [2+2] topotactic photocycloaddition takes place, and the two possible dimers 25/A and 25/B slowly accumulate in the reaction mixture. ${ }^{54}$ Under $0.1 \mathrm{M}$ concentration, the formation of the dimers was negligible, and only the $E-Z$ isomerization took place.

The choice of solvent is critical in photochemistry as well. There are two different types, the reactive (water, alcohols, aromatics, alkyl halogenides), absorbing UV light and the unreactive (alkanes, esters), which do not absorb in the UV range. For photoisomerization, the use of unreactive solvents is recommended.

\subsubsection{Z-selective catalytic hydrogenation of alkynes}

A very general method for the preparation of $Z$-cinnamic acid $1 / Z$ is the hydrogenation of phenylpropiolic acid $\mathbf{2 6}$ with Lindlar's catalyst (Figure 12), which is a 
$P b$-poisoned heterogeneous palladium catalyst ${ }^{55}$ (usually $5 \% P d$ by weight) deposited on a support of low surface area like $\mathrm{CaCO}_{3}$ or $\mathrm{BaSO}_{4}$. During the hydrogenation, the catalyst is further modified with quinoline $\mathbf{2 7}$ or with 3,6-dithia-1,8-octanediol 2856, therefore the first equivalent of hydrogen enters via syn addition to produce Z-alkenes.

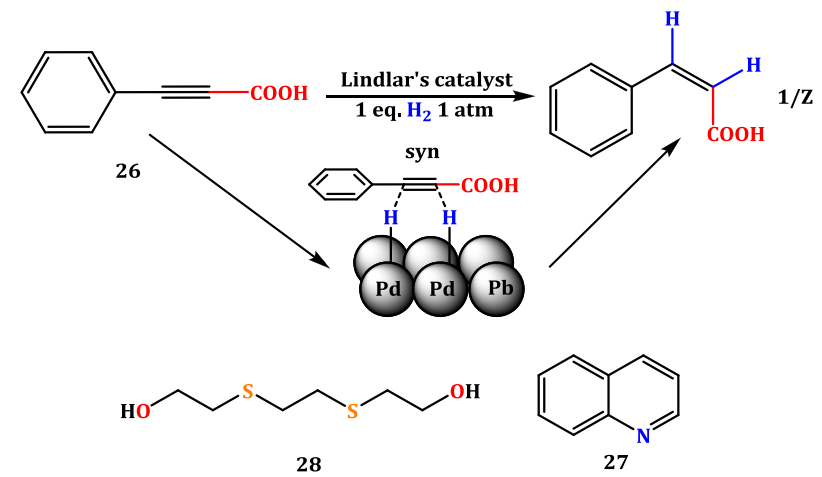

Figure 12 The mechanism of the Lindlar-type hydrogenation

The yield was quite good, more than $90 \%$ and the Z:E selectivity was around $95: 5 .^{57}$

An interesting variant of the Lindlar procedure is the so-called P-2 nickel catalyst, which is a $\mathrm{Ni}_{2} \mathrm{~B}$ powder, (usually generated in situ), which shows high $Z$ selectivity for alkyne hydrogenation. ${ }^{58}$

\subsubsection{The Horner-Wadsworth-Emmons (HWE) olefination}

The HWE method $59,60,61$, which is the offspring of the famous Wittig olefination $^{62,63}$, is one of the most favorable techniques for the stereoselective synthesis of olefinic esters. The mechanism is similar to that of the Wittig reaction, but the reagents are phosphonates instead of phosphoranes, and the alkyl group should contain an EWG, e.g., ester or nitrile groups. The different phosphonates can be synthesized utilizing the well-known Michaelis-Arbuzov rearrangement ${ }^{64,65,66}$, where an alkyl halide reacts with organic phosphites to give the desired phosphonate esters like trimethyl phosphonoacetate 29. In this reaction, the carbanion is generated with a strong base $\left(\mathrm{NaH}, t\right.$-BuOK, KHMDS 32) under cryogenic circumstances $\left(-78^{\circ} \mathrm{C}\right)$, usually in ethers like THF in the presence of complexone like 18-crown-6 31. The stabilized carbanion can react with carbonyl compounds like 7 via nucleophilic addition, to give erythro 29/4 and threo 29/3 betaines, being the rate-limiting step (Figure 13). ${ }^{67}$ The oxaphosphetanes are formed as well here, and the elimination of 29/5 and 29/6 leads to $E$ and $Z$ olefinic 


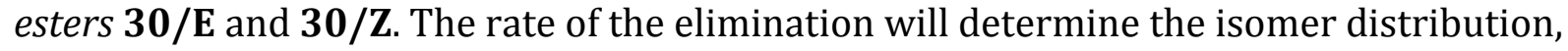
which is around 7:3 (E:Z) for cinnamoyl esters if the R- group is small (methyl or ethyl).

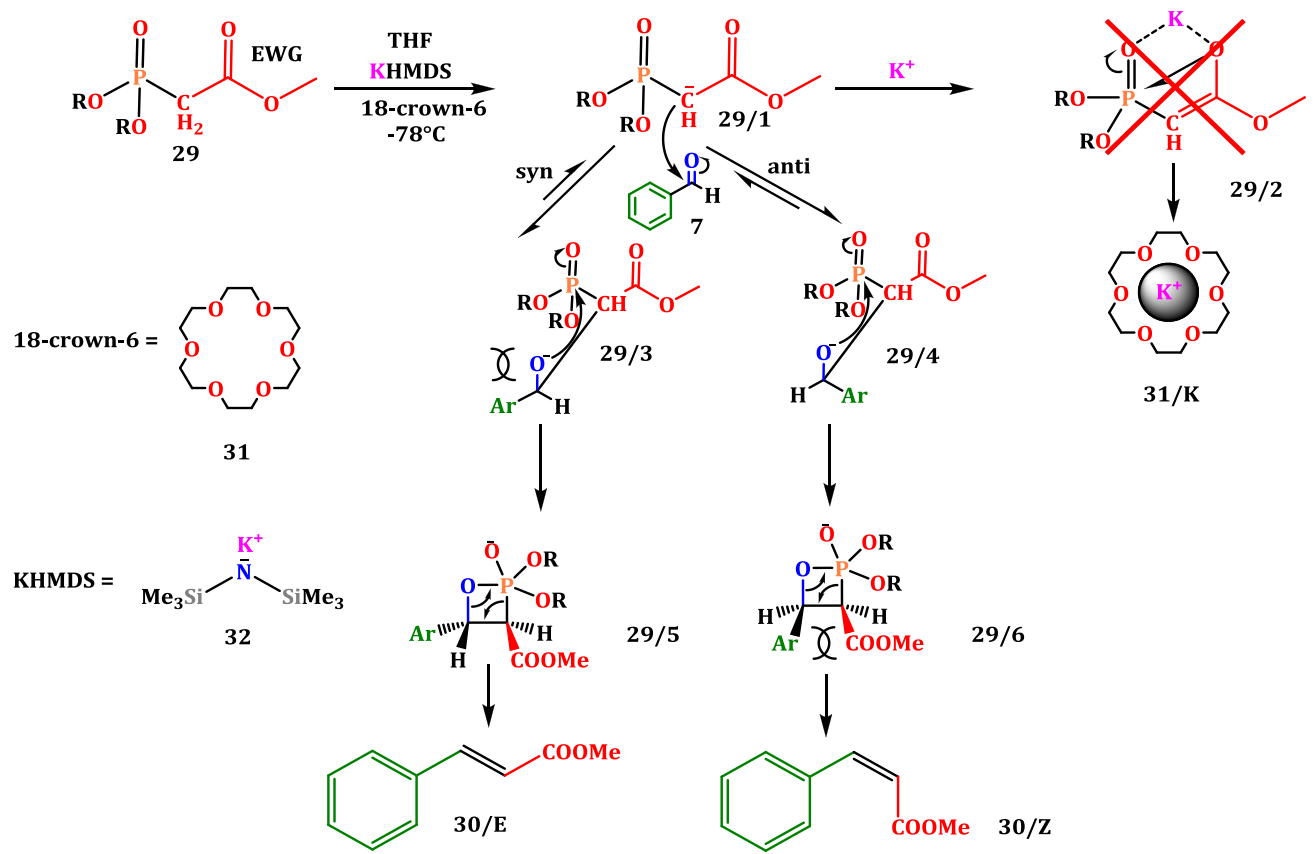

Figure 13 The working mechanism of the Horner-Wadsworth-Emmons condensation reaction

If the phosphonate has large side group, there will be a steric hindrance between the phosphonate and the ring of the aldehyde, making the syn addition sterically unfavorable and this will facilitate the anti route, which provides the $Z$ isomer. Four basic phosphonate reagents can be used for the stereoselective preparation of $Z$ cinnamic acid esters: the Still-Gennari68 33 bis-trifluoroethyl(R)phosphonoacetate, the Breuer $^{69} 34$ dimethyl-dioxaphospholane-(R)acetate, the Patois-Savignac ${ }^{70} 35$ dimethyldiazaphospholidine(R)acetate and the Ando ${ }^{71} 36$ bis-o-cresyl(R)phosphonoacetate (Figure 14).

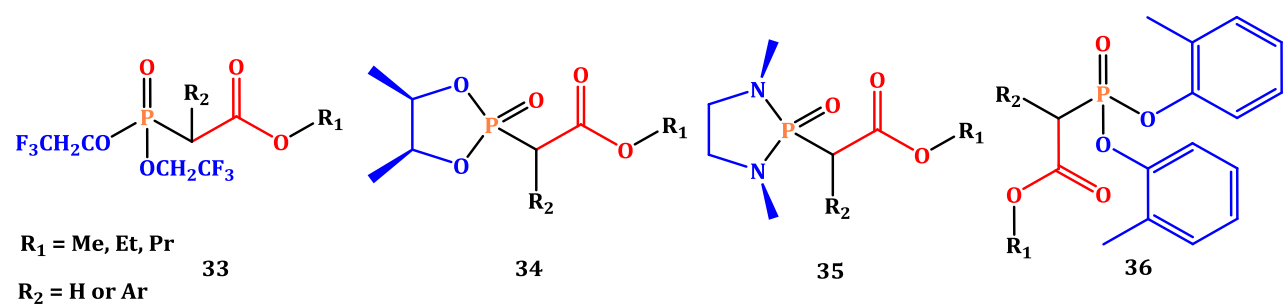

Figure 14 HWE-type phosphonates for Z-selective olefin synthesis

The HWE reaction can be applied for the synthesis of the $\alpha$-substituted cinnamic acids $\mathbf{1 8}$ /E-Z as well, with the same reagents, if the $\mathbf{R} \mathbf{2}$ group is an aromatic ring. From 
the modifications listed above, the Still-Gennari 33 and the Ando 36 variants show the best $Z$ selectivity for aromatic aldehydes.

\subsubsection{Z-selective olefin metathesis}

The olefin metathesis entails the redistribution of fragments of alkenes by the scission and regeneration of carbon-carbon double bonds. In spite of impressive advances in the development of catalytic olefin metathesis reactions ${ }^{72}$, the lack of stereoselective access to $Z$ alkenes represented a significant shortcoming in olefin metathesis for decades. Most of the metathesis reactions afford either mainly $E$ alkenes or a mixture of the two isomers. Very recently, through the development of new Mo- or $W$-alkylidene complexes and $R u$-carbene complexes, a general access to $Z$ alkenes in high to excellent stereoselectivities through olefin metathesis was finally realized. ${ }^{73}$ As one of the earliest demonstrations of the this new synthetic utility of selective ring opening cross-metathesis (ROCM) reactions, the Crowe group reported the first example of Zselective cross-metathesis of acrylonitrile $\mathbf{3 8}$ and various terminal olefins like styrene $\mathbf{3 7}$, catalyzed by Schrock catalyst $\mathbf{3 9}$ shown in Figure 15.74

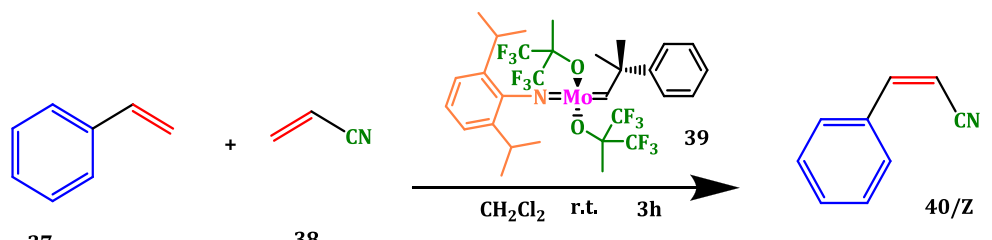

Figure 15 Z-selective cross-metathesis of acrylonitrile (82) with terminal alkenes like styrene (81)

The obtained cinnamonitrile $\mathbf{4 0 / Z}$ can be hydrolyzed under alkaline or acidic conditions to access cinnamic acids $(\mathbf{1} / \mathbf{Z})$.

\subsection{Synthetic ways to $\alpha$-substituted cinnamic acids}

The considerations concerning the synthesis of the $\alpha$-substituted cinnamic acids are very similar to those of cinnamic acid (1/E); however, the isomer distribution can be adjusted with the modification of the reaction time, temperature and with the reagent type as well.

\subsubsection{The modified Perkin and other relevant condensations}

The first method for the synthesis of $\alpha$-phenylcinnamic acid was carried out with the modified Perkin-Oglialoro condensation between benzaldehyde derivative $\mathbf{7 / \mathbf { R }}$ and 
phenylacetic acid derivative $\mathbf{1 7} / \mathbf{R}$ (or the corresponding alkali salt $\mathbf{1 7} / \mathbf{R}-\mathbf{N a}$ ), catalyzed with TEA in $\mathrm{Ac}_{2} \mathrm{O}^{75}$ (Figure 16). The aromatic aldehyde and the aromatic acetic acid derivative can contain a heterocycle as well (furyl-, thienyl-) ${ }^{76}$; thus, a wide variety of $\alpha$ substituted cinnamic acids can be prepared with these methods, obtaining both isomers with high yields.

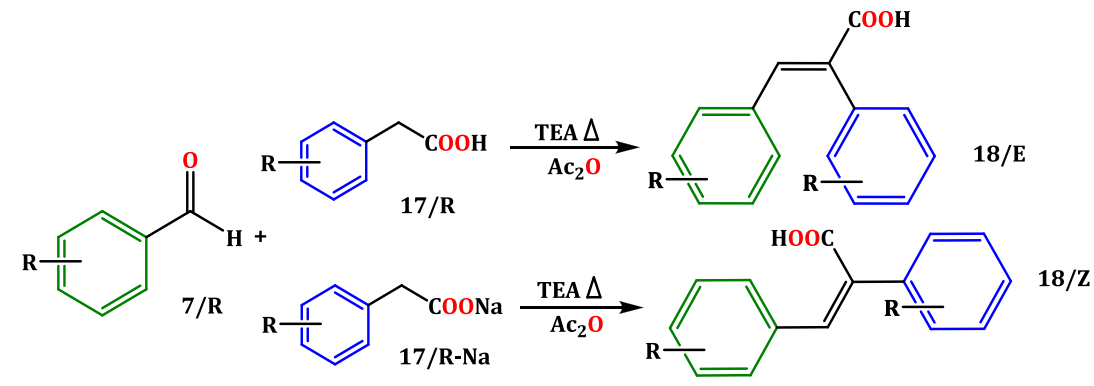

Figure 16 The modified Perkin and Oglialoro condensations

Other condensation reactions such as the HWE method (2.4.3) can be applied as well to produce $\alpha$-substituted cinnamic acids, if we are able to create the corresponding phosphonates 41 (Figure 17) for the synthesis, where the R2 group can be benzyl- 42, pyridyl-43, furyl-44, thienyl- 45 or selenophenyl- 46.<smiles>[R1]OC(=O)C([R2])P(=O)(O[R1])O[R1]</smiles>

41<smiles>[R]=[W]</smiles>

42<smiles>c1ccncc1</smiles>

43<smiles></smiles>

44<smiles>c1ccsc1</smiles>

45<smiles>c1cc[se]c1</smiles>

46

Figure 17 HWE phosphonate for the synthesis of $\alpha$-substituted cinnamic acid isomers

\subsubsection{Synthesis of $\alpha$-substituted cinnamic acids via addition reactions}

Various other methods for the preparation of $\alpha$-phenylcinnamic acid are already mentioned, however each described methods are based on condensation. Other relevant reactions can be found in literature, like the radical Kharasch ${ }^{77}$ addition of halomethanes 48 to stilbene $\mathbf{4 7 / Z}$ trough 49 (Figure 18$)^{78}$ or the hydrocarboxylation of diphenylacetylen in the presence $\mathrm{Et}_{2} \mathrm{Zn}$ and $\mathrm{CsF}^{79}$, can be found; however, the produced molecules will carry the geometry of the starting material; thus, the selectivity is predetermined in these reactions and the preparation of the starting compound is difficult is some cases. 


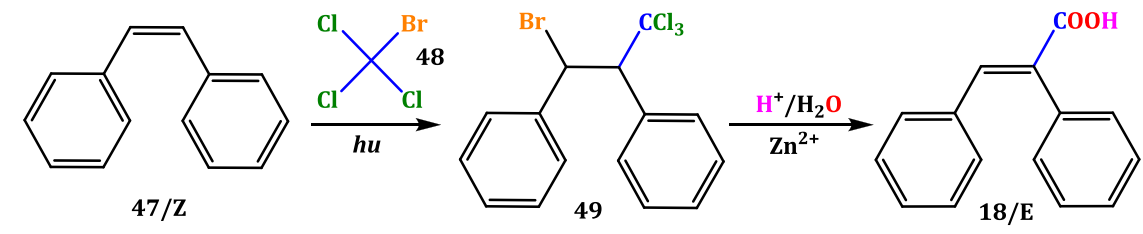

Figure 18 The radical addition of bromotrichloromethane (48) to stilbene (47/Z), than the hydrolysis of (49) under acidic conditions

\subsection{Secondary chemical bonds and the self-assembling capabilities of cinnamic acids}

\subsubsection{About secondary chemical bonds}

There are several well-defined secondary chemical bonds that can hold small and large molecules together. Each secondary chemical bond is based on the electrostatic or dipole-dipole interactions between strong or permanent dipoles of neutral molecules and ions respectively. They can be categorized by the type and the strength of the appropriate interaction as follows:

- hydrogen bonds (inter- and intramolecular) 80

○ First-order hydrogen bonds $(1.9-38.6 \mathrm{kcal} / \mathrm{mol})^{81}$

- $\mathrm{F}-\mathrm{H}$...F $(38.6 \mathrm{kcal} / \mathrm{mol})$

- $\quad 0-\mathrm{H} \ldots \mathrm{N}(6.9 \mathrm{kcal} / \mathrm{mol})$

- $0-\mathrm{H} \ldots \mathrm{O}(5.0 \mathrm{kcal} / \mathrm{mol})$

- $\quad \mathrm{N}-\mathrm{H} \ldots \mathrm{N}(3.1 \mathrm{kcal} / \mathrm{mol})$

- $\quad \mathrm{N}-\mathrm{H}$...O (1.9 kcal/mol)

○ Second-order hydrogen bonds (1-6 kcal/mol) $)^{82,83}$

- $\mathrm{O}-\mathrm{H} \ldots \mathrm{X}(\mathrm{X}=\mathrm{S}, \mathrm{Se}, \mathrm{Te}, \mathrm{Hlg})$

- $\mathrm{N}-\mathrm{H} \ldots \mathrm{X}$

- $\mathrm{C}-\mathrm{H} \ldots \mathrm{F}$

- $\mathrm{C}-\mathrm{H} . . . \mathrm{O}$

- $\mathrm{C}-\mathrm{H} \ldots \mathrm{N}$

- $\mathrm{C}-\mathrm{H} \ldots \mathrm{S}$

○ Dihydrogen bond (between hydrides and positively polarized hydrogens, $1-25 \mathrm{kcal} / \mathrm{mol})^{84,85}$

- alkali-H...H-X (X = O,N,S,C,Hlg)

- B-H... H-X 
- $\mathrm{Al}-\mathrm{H} \ldots \mathrm{H}-\mathrm{X}$

- $\mathrm{Ge}-\mathrm{H} . . . \mathrm{H}-\mathrm{X}$

- transition metal-H... H-X

- $\quad$ van der Waals forces ${ }^{86}$

○ Keesom (permanent dipole-dipole interaction)

- Debye (induced-dipole interaction)

○ London dispersion force (between nonpolar molecules)

- $\quad$ Other weak interactions ${ }^{87}$

$\circ \pi-\pi$ stacking (between aromatic rings, $0.5-3 \mathrm{kcal} / \mathrm{mol})^{88}$

○ $\quad$ - $-H$... $\pi$ stacking

○ cation $-\pi$ bonding

○ anion $-\pi$ bonding

○ halogen bonding (similar to hydrogen bond, A...X-A) ${ }^{89}$

The interactions listed above are very important in defining the physical properties of materials, like the melting and boiling point (water ${ }^{90}$ vs. hydrocarbons) or even the viscosity (sugars) and solubility, the structure forming properties (multiple hydrogen bonds in $\mathrm{DNA}^{91}$ and polymers), the reactivity (intramolecular hydrogen bonds in enols), etc.

\subsubsection{Possible interactions between cinnamic acids}

Many of the mentioned secondary bonds are possible among cinnamic acid derivatives; therefore, they are good models for observing various aggregations types in all three thermodynamic states, or even in the adsorbed phase.

A. First-order hydrogen bonds between cinnamic acids

One of the strongest hydrogen bond is the $0-\mathrm{H} . . .0$ type, which is very general between carboxylic acids. If the formation of the bond is not hindered by large substituents and the carboxylic group is in the syn periplanar conformation, a so-called cyclic or double hydrogen bond can be established. The structure of the cyclic dimer of two cinnamic acid monomers $\mathbf{1 / E}$ is displayed in Figure 19, where the hydrogen bond is illustrated as dashed green line. 

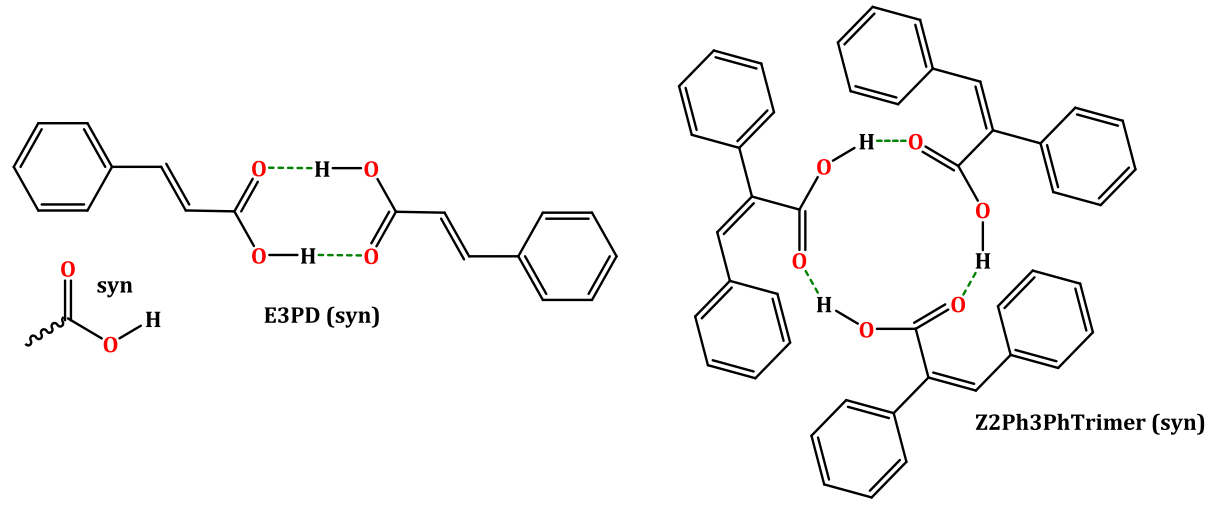

Figure 19 Cyclic double and triple $0-\mathrm{H} . . .0$ hydrogen bonds between two cinnamic acid (1/E, E3PhD) and Z$\alpha$-phenylcinnamic acid (Z2Ph3PhTrimer) molecules

The double hydrogen bond is significantly stronger than two separated $\mathrm{O}-\mathrm{H}$...O interactions, the binding energy is usually in the $14-17 \mathrm{kcal} / \mathrm{mol}$ range ${ }^{92,93}$ instead of 10 $\mathrm{kcal} / \mathrm{mol}$ that can be expected from the energy of a single $0-\mathrm{H} \ldots \mathrm{O}$ bond $(5-6 \mathrm{kcal} / \mathrm{mol})$. The short bond length indicates the strength of the interaction, it is in the 1.65-1.81 $\AA^{15}$ range for various cinnamic acid derivatives ${ }^{94}$ that is very close to the average distances, which can be measured among covalently bonded atoms. Due to the strength of these bonds, almost every cinnamic acid derivative forms dimers in the solid state uniformly 95 , and the cyclic dimers will stay together either in aprotic solvent ${ }^{82}$ or sometimes in the gas phase $\mathrm{e}^{96}$ as well. For $\alpha$-substituted cinnamic acids, the formation of hydrogen-bonded aggregates via the carboxylic groups, did not stop at the dimer, but hydrogen-bonded cyclic trimer was also formed in the solid state and even in concentrated solution. ${ }^{97}$

B. Second-order hydrogen bonds between cinnamic acids

As it has been mentioned at the secondary chemical bonds, many weaker hydrogen bonds are possible between aromatic protons and heteroatoms. We have already seen the structure of the $\mathbf{E 3 P h}(s y n)$ dimer, but the anti conformer of the carboxylic group also exists $^{98}$, and with the anti conformer, the formation of the cyclic dimer is prohibited, due to inappropriate bond lengths and angles. In this case, the aromatic $\mathrm{C}-\mathrm{H}$...O interaction became favorable in the solid state ${ }^{95}$ (Figure 20); however, the incidence of the anti conformer is rare (1-5\%), due to the higher energy content (1-2 kcal/mol over the syn conformer). ${ }^{99}$ The energy of the (aromatic)C-H...O hydrogen bond is in the $0.5-1.2$ $\mathrm{kcal} / \mathrm{mol}$ range, and the bond length varies from 2.4 to $2.6 \AA .{ }^{100}$ Two different structures can be seen in Figure 20 for the $\mathrm{C}-\mathrm{H}$...O interaction (represented by orange dashed lines) between the anti conformers of cinnamic acid (1/E, E3Ph). 

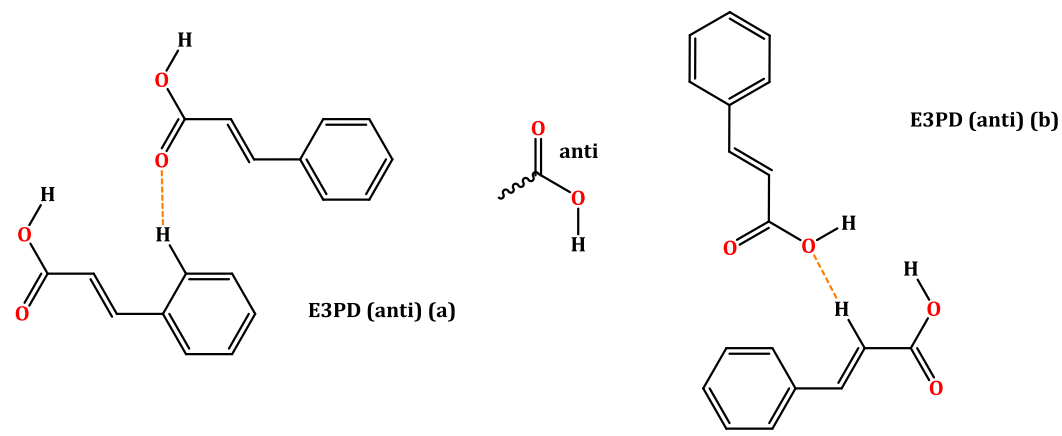

Figure 20 Various C-H...O interactions between cinnamic acid anti conformers E3PhD-anti (a) and (b)

A little bit stronger hydrogen bonds may be formed between heteroaromatic rings with cyclic $\mathrm{C}-\mathrm{H} \ldots \mathrm{O}$ and $\mathrm{C}-\mathrm{H} . . . \mathrm{N}$ interactions ${ }^{101}$, and data are found for the weaker C-H...S bond as well. Some other types of hydrogen bonds should be mentioned here, for instance, the aromatic C-H...F bond between fluoro substituted cinnamic acids. ${ }^{82}$ As it has been mentioned before, these interactions are weaker compared to the "traditional" hydrogen bonds, due to the slightly polarized aromatic protons ${ }^{10}$; however, the cyclic hydrogen bond among heteroaromatic rings or substituted phenyl rings, can be as strong as $1-6 \mathrm{kcal} / \mathrm{mol}$, which is not negligible in the solid state, or even in the liquid phase..$^{102}$ Due to the lower bonding energies, the average bond length is quite long: 2.4-3.5 Å.103,104 A possible cyclic C-H...0 agglomerate, consisting of E-3-(2-furyl)propenoic acid dimers E32FD, and a fluorophenyl substituted Z24FPh34FPhD are shown in Figure 21 (where the weak hydrogen bonds represented as pink dashed lines).
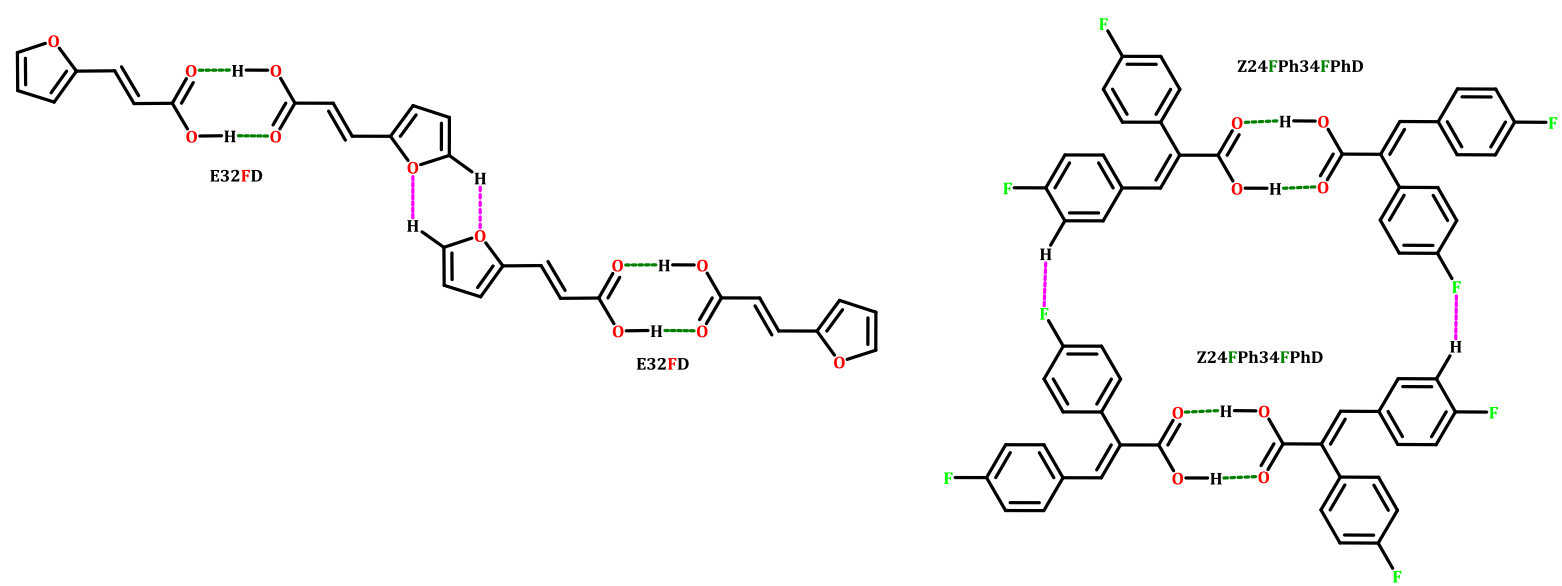

Figure 21 Example for the cyclic heteroaromatic $\mathrm{C}-\mathrm{H} . . . \mathrm{O}$ hydrogen bond and substituted aromatic $\mathrm{C}-\mathrm{H}$...F hydrogen bond, formed between dimers

C. $\pi$-stacking interactions between cinnamic acids

The weakest interactions observed for cinnamic acids are the $\pi-\pi$ stacking and the $\mathrm{C}-\mathrm{H} . . . \pi$ close contact. It is known that these kinds of interactions play role in the 
conformation of proteins and other biologically important molecules ${ }^{105}$, and they determine the crystal structure of aromatic compounds. There are several different theories about the nature of the $\pi$-stacking interaction, but the most convincing is the electrostatic model ${ }^{106}$, which found direct correlation between the structure of different $\pi$-stacked compounds and the substituents of the aromatic ring. ${ }^{107}$ The three basic models of the $\pi$-stacked structures are displayed in Figure 22.
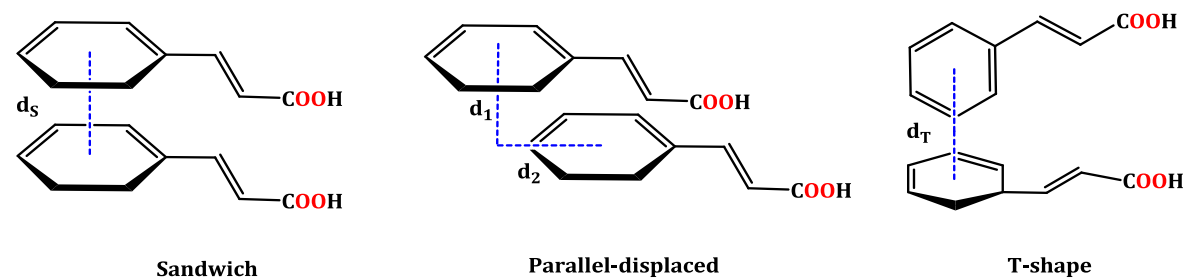

Figure 22 The three basic $\pi$-stacking interactions presented on cinnamic acid (1/E)

The average bonding energy is between $0.5-3.0 \mathrm{kcal} / \mathrm{mol}$ and the order in ascending order for benzene derivatives is the following: parallel-displaced, $2.6 \mathrm{kcal} / \mathrm{mol}$ $\left(\mathrm{d}_{1}=3.6 \AA \mathrm{d}_{2}=1.6 \AA\right)$; T-shaped or (aromatic)C-H...T, $2.5 \mathrm{kcal} / \mathrm{mol}\left(\mathrm{d}_{\mathrm{T}}=5.0 \AA\right.$ ); and the sandwich-type interaction, $1.7 \mathrm{kcal} / \mathrm{mol}(\mathrm{ds}=3.9 \AA) .{ }^{108}$ The parallel-displaced and the sandwich-type interactions are present in cinnamic acid agglomerations in the solid state, as can be deduced from crystallographic data. ${ }^{95,109}$

\subsubsection{Self-assembling of various molecules over transition metal surfaces}

As it was seen, several different types of interactions and bonds can be formed among cinnamic acids, even if they contain EWG substituent(s) on the aromatic ring, or when the aromatic ring is a heterocycle. With the use of metal surfaces, we can add another dimension to the organizing forces via the attraction between organic functional groups (mostly with groups containing $\mathrm{O}, \mathrm{N}$ or $\mathrm{S}$ atoms) and transition metals (e.g., $\mathrm{Pt}$, $P d, A u, A g)^{110}$. Many examples can be found in the scientific literature describing the chemisorption of organic compounds over metal surfaces via their heteroatoms. There are two types of chemisorption, which may involve self-assembly:

- The stronger covalent adsorption taking place via the cleavage of hydrogen from the terminal $-\mathrm{OH},-\mathrm{COOH},-\mathrm{NH}_{2}$ or $-\mathrm{SH}$ functional groups. ${ }^{111}$ The chemisorbed layer is usually called self-assembled monolayer (SAM). The formation mechanism of the covalent-type SAM is seen in Figure 23. The first step (I.) is the physisorption of the molecules (presented as grey sticks where the dark "head" can be $-\mathrm{COOH},-\mathrm{OH},-\mathrm{NH}_{2}$ or 
-SH functional groups). The second step (II.) is the formation of the covalent $\mathrm{M}-\mathrm{O}, \mathrm{N}, \mathrm{S}$ bond via cleave the hydrogen off the functional head-group (drawn as red "heads"). In a further step (III.), the chemisorbed molecules start to assemble from parallel to perpendicular fashion, organized by second-order chemical bonds among the side groups and chains. The final state (IV.) is what we call SAM, a well-ordered carpet-like structure, covering the surface of the metal and completely changing its electronic and chemical properties.

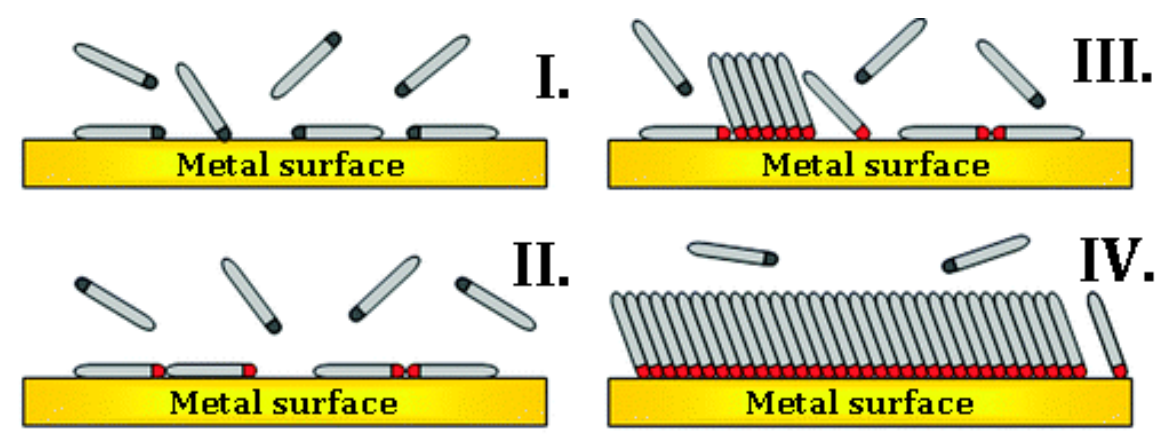

Figure 23 The common mechanism of covalent self-assembling over metal surface ${ }^{112}$

- The weaker coordinative adsorption via $\mathrm{R}-\mathrm{O}-\mathrm{R}, \mathrm{R}=\mathrm{N}-\mathrm{R}, \mathrm{R}-\mathrm{S}-\mathrm{R}$ groups without bondcleavage ${ }^{111}$, where the heteroatom can be located in an aromatic ring or surrounded by alkyl neighbors. The formation of the SAM follows the same route as shown in Figure 23, and oriented nearly perpendicular to the surface for simple heteroaromatics like pyridine $\mathbf{4 3}^{113,114}$ and thiophene $\mathbf{4 5 . 1 1 5}$ If the substance contains more than one coordinating heteroatoms, relatively far from each other, the formation of the SAM may stop at stage II., and the orientation stays parallel to the surface. ${ }^{115,116}$

The SAM layers are widely used for surface modification mainly for anticorrosion coating117, changing the wetting and adhesion properties, achieving chemo- and biocompatibility ${ }^{118}$, or for the creation of nanostructures made for electronic use, like sensors or conducting polymers (usually made by polymerization of the adsorbed molecules).119,120

If the SAM has functionalized tail group, another layer of molecules can be attached to it and the procedure can be repeated again to grow a multilayer. This technique was developed by DuPont ${ }^{121}$ to build uniform coating on glass, and is known as Layer-byLayer (LbL) method. The original procedure uses electrostatic forces to build the layers by altering the positively and negatively charged particles. ${ }^{122}$ However, many other 
interactions can hold layers together like hydrogen bonds or dispersion forces. ${ }^{123}$ The main advantage of the procedure is its simplicity. The layers form spontaneously, i.e., simple dipping (dip-coating) and washing steps are only required to form the multilayer.

As was seen above, heteroaromatic molecules can form SAMs, especially the sulfurcontaining derivatives like thiophene 45; therefore, heterocyclic cinnamic acids have great potential in forming SAMs over gold or silver surfaces, and through intermolecular hydrogen bonds mentioned earlier, the formation of LbL films are possible as well. 


\section{THE MAIN AIMS OF THE DISSERTATION}

The goals of the work leading to this dissertation are as follows:

- finding a cheap, successful synthetic way to prepare stereochemically pure $E-2$ and/or 3-(furyl/thienyl/pyridyl/selenophenyl)cinnamic acids, because some of them have very high price on the list of chemical suppliers;

- elaborating an expedient and affordable way for the preparation of hardly accessible Z-3-(furyl/thienyl/pyridyl/selenophenyl)cinnamic acids, because none of them are available commercially;

- studying the self-assembling features of the above molecules and many of their substituted varieties in solution, the solid state and the adsorbed phase on metal surfaces (gold and silver), identifying the possible secondary interactions, with the combination of various spectroscopic measurements $\left({ }^{1} \mathrm{H}\right.$ NMR, IR) and surface inspection techniques (SEM, AFM, IRM);

- complementing the experimental results with computational methods at high theoretical level (geometry and energy calculations for the aggregates, including the computation of precise energies of the secondary bonds and the full conformational analysis of the individual molecules and occasionally the dimers as well). 


\section{EXPERIMENTAL PART}

\subsection{Materials}

\subsubsection{The molecules studied}
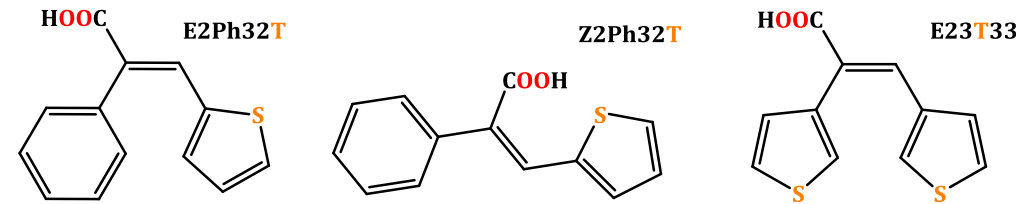

Z23T33T

E-2-phenyl-3-(2-thienyl)propenoic acid $\quad Z$-2-phenyl-3-(2-thienyl)propenoic acid $\quad$ E-2,3-di(3-thienyl)propenoic acid
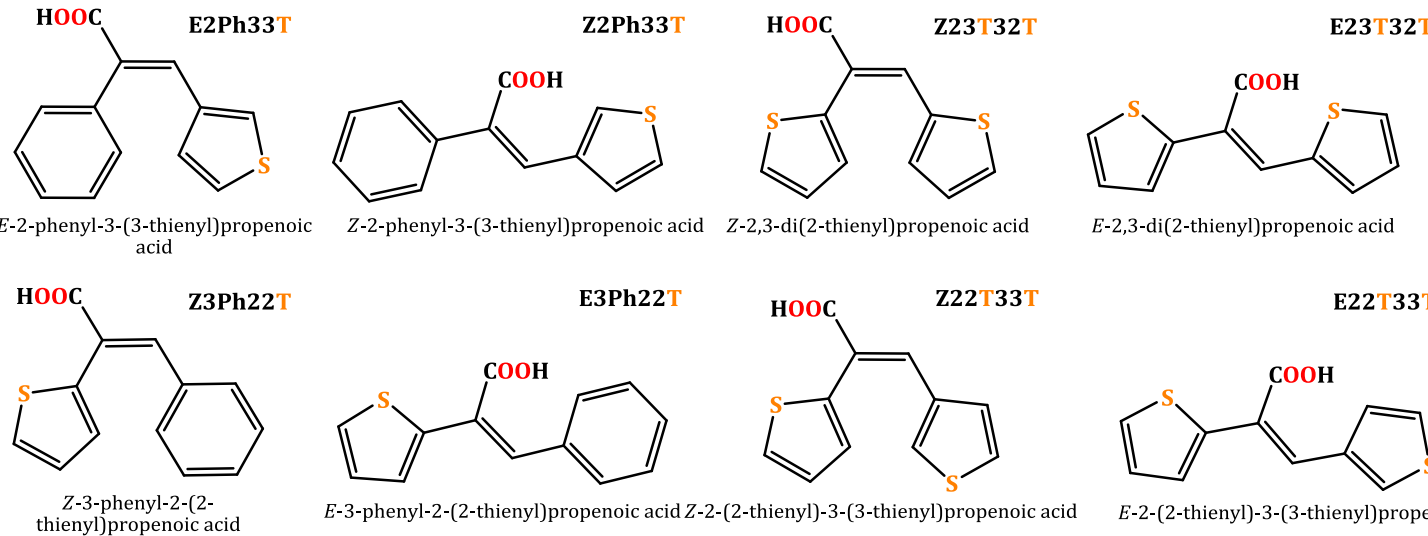

$Z$-2-phenyl-3-(3-thienyl)propenoic acid $\quad Z$-2,3-di(2-thienyl)propenoic acid

E-2,3-di(2-thienyl)propenoic acid

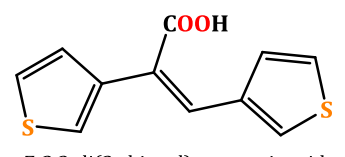

Z-2,3-di(3-thienyl)propenoic acid

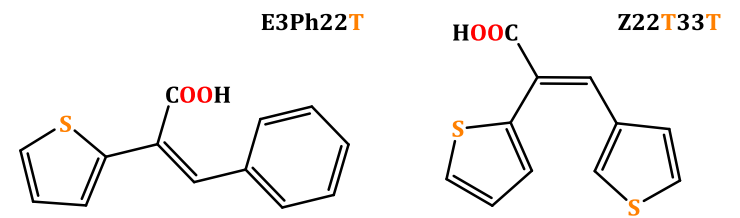

E22T33T thienyl)propenoic acid<smiles>O=C(O)/C(=C/c1ccccc1)c1ccsc1</smiles>
E-3-phenyl-2-(2-thienyl)propenoic acid Z-2-(2-thienyl)-3-(3-thienyl)propenoic acid
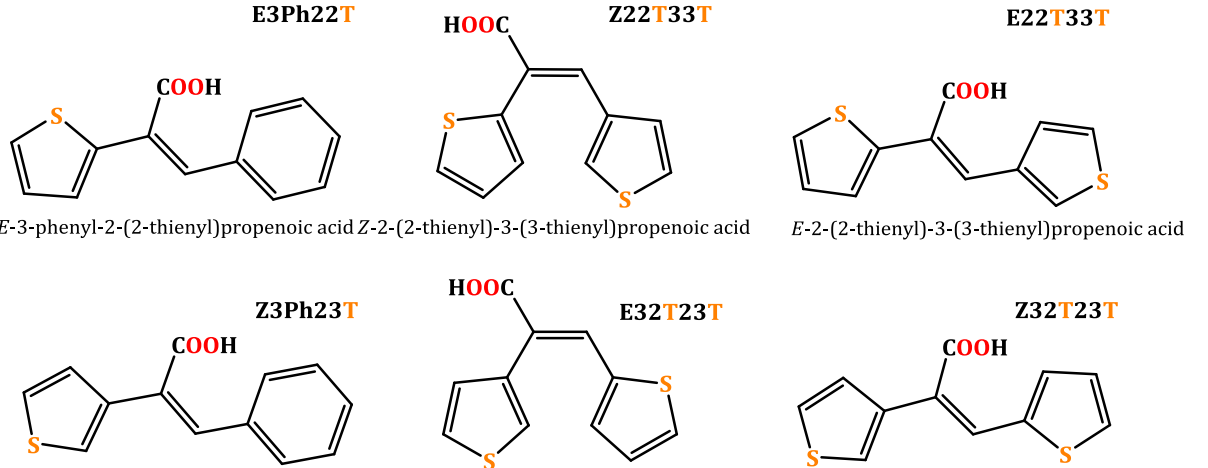<smiles>O=C(O)/C(=C/c1cccs1)c1ccsc1</smiles><smiles>O=C(O)/C(=C/c1cccs1)c1ccsc1</smiles>
$E$-3-phenyl-2-(3-
thienyl)propenoic acid Z-3-phenyl-2-(3-thienyl)propenoic acid E-3-(2-thienyl)-2-(3-thienyl)propenoic acid

Z-3-(2-thienyl)-2-(3-thienyl)propenoic acid

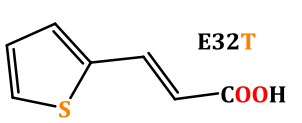

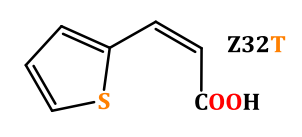

Z-3-(2-thienyl)propenoic acid

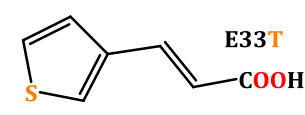

E-3-(3-thienyl)propenoic acid

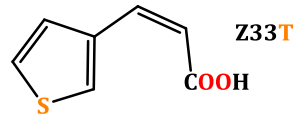

Z-3-(3-thienyl)propenoic acid<smiles>O=C(O)/C(=C/c1ccccc1)c1cccnc1</smiles>

Z-3-phenyl-2-(3-pyridyl)propenoic acid

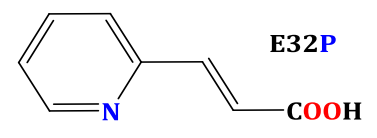
E-3-(2-pyridyl)propenoic acid<smiles>O=C(O)/C=C\c1ccccn1</smiles>
Z-3-(2-pyridyl)propenoic acid

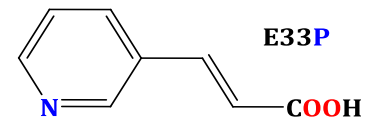

E-3-(3-pyridyl)propenoic acid<smiles>O=C(O)/C=C\c1cccnc1</smiles>

Z-3-(3-pyridyl)propenoic acid

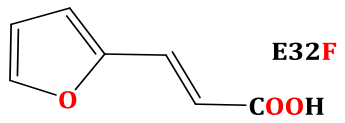

E-3-(2-furyl)propenoic acid

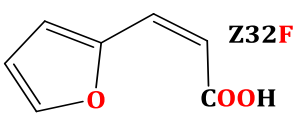

Z-3-(2-furyl)propenoic acid

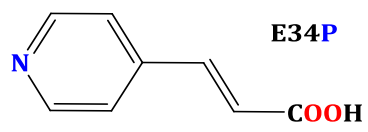

E-3-(4-pyridyl)propenoic acid
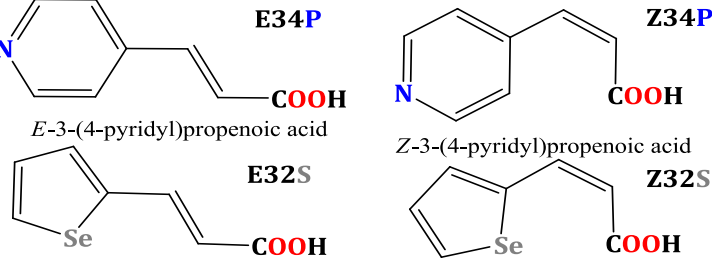

Z-3-(4-pyridyl)propenoic acid
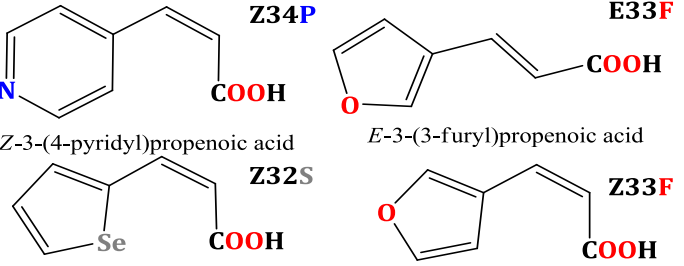

$Z$-3-(2-selenophenyl)propenoic acid $\quad Z$-3-(3-furyl)propenoic acid

Figure 24 The structure of the studied cinnamic acid derivatives, substituted with one or two heteroaromatic ring(s) 
The structure of the studied materials of this dissertation can be seen in Figure 24.

\subsubsection{Solvents for NMR spectroscopy}

○ DMSO-d6 (hexadeutero dimethyl sulfoxide) (99.96 atom\% D, 0.03\% TMS) (Sigma-Aldrich, NMR solvent)

○ $\mathrm{D}_{2} \mathrm{O}$ (deuterium oxide, heavy water) (99.9 atom\% D, 0.01\% DSS) (SigmaAldrich, NMR solvent)

○ $\mathbf{C D C l}_{3}$ (deuterochloroform) (99.8 atom\% D, 1 V/V\% TMS) (Sigma-Aldrich, NMR solvent)

○ $\mathrm{CD}_{3} \mathrm{OD}$ (tetradeuteromethanol) (99.8 atom\% D, 0.03\% TMS) (SigmaAldrich, NMR solvent)

Other reagents and supporting materials applied for the experiments are listed in the Appendix.

\subsubsection{Polycrystalline metal surfaces}

\section{- Gold and silver surfaces}

The polycrystalline metal surfaces were created by the Pulsed Laser Deposition (PLD) ${ }^{124}$ technique. This method uses incident focused UV-laser beam to vaporize (ablate) bulk metal, which is placed in a vacuum chamber, and the liberated plasma particles condense on the substrate, placed in front of the plume (Figure 25). With the control of the pulse length, the frequency and the energy of the laser beam, very thin metal layers can be created on several substrates (usually glass, quartz or various metals). The common PLD setup is displayed in Figure 25. For the measurements $30 \times 30 \mathrm{~mm}$ glass microscope slides were applied as substrates, and $99.99 \%$ gold and silver (Good Fellow) plates as targets. The applied laser was a krypton fluoride (KrF) excimer laser $(\lambda=248 \mathrm{~nm})$, focused on the metal target in a $5 \mathrm{~mm}^{2}$ spot. The pulse length was $18 \mathrm{~ns}$, the repeating frequency was $10 \mathrm{~Hz}$ and the energy of a single impulse was $106 \mathrm{~mJ} /$ pulse. 


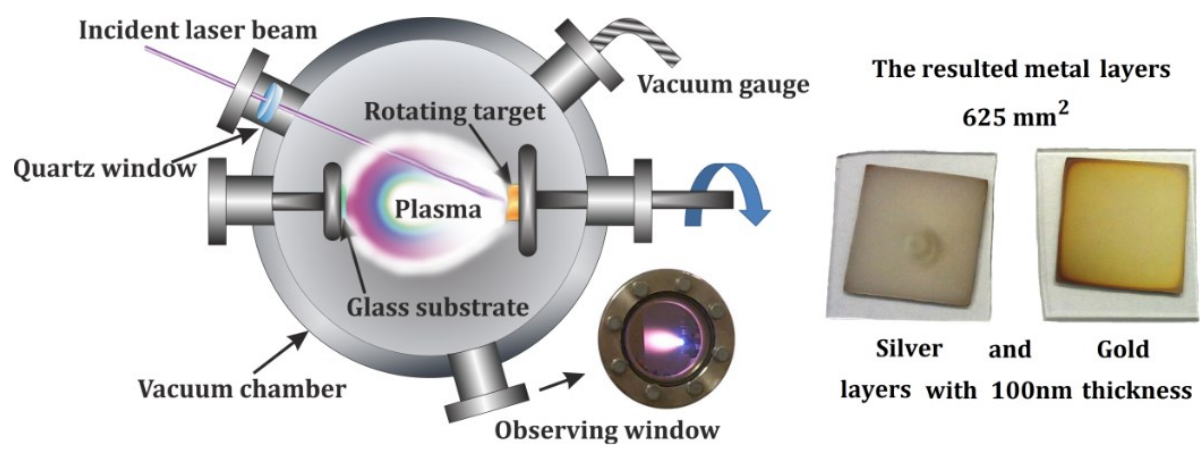

Figure 25 Schematic representation and the working mechanism of a common PLD setup and the resulting metal layers

Each metal layer was created with 15,000 pulses, and the resulting layer thickness was around $100 \mathrm{~nm}$. The area of the created metal surface was $25 \times 25 \mathrm{~mm}$ $\left(625 \mathrm{~mm}^{2}\right)$ in every case. The homogeneity of the metal layers was checked by scanning electron (SEM) and atomic force microscopies (AFM). At the atomic level, it was found to be acceptable for topological studies (1-2 nm peaks between the huge 1-3 $\mu \mathrm{m}$ droplets, coming from the perimeter of the ablation craters, where the heat is no longer enough to vaporize the metal).

\section{- Creating the self-assembled layers}

Each metal layer was treated with boiling DMF to remove the oxide cover from the surface $^{125}$, and then, they were washed in a chloroform bath, combined with ultrasonic cleaning (50 W US, $20 \mathrm{kHz}, 10 \mathrm{~s}$ ) to remove all impurities before the experiments. The slides with the deposited metal layers were dipped (dip-coating method) into the $0.1 \mathrm{M}$ solution of the proper cinnamic acid derivative dissolved in chloroform $(0.1 \mathrm{M}$ is far from the saturation point of the five membered derivatives, but the pyridyl-derivatives are barely soluble in chloroform, so the selected concentration for them is $0.001 \mathrm{M}$ ) for $48 \mathrm{~h}$ to create the self-assembled layers. After the treatment, the layers were washed with $3 \times 5$ $\mathrm{ml}$ of chloroform to prevent the formation of non-bonded crystals over the selfassembled layers.

\subsection{Instrumental methods}

\subsubsection{Analytical and structure analysis methods}

- Gas chromatography (GC)

All gas chromatographic measurements were carried out on a HP-4890 gas chromatograph equipped with a flame ionization detector (FID). A HP-5 type polysiloxane 
cross-linked (Me:Ph, 95:5) $50 \mathrm{~m} \times 0.32 \mathrm{~mm}$ capillary column with $25 \mu \mathrm{m}$ internal diameter and $0.52 \mu \mathrm{m}$ film thickness was applied. The instrument was used in the splitless mode, and the column head pressure was 2 bars. The FID, was fed with 99.998\% $\mathrm{H}_{2}$ (Messer) and 99.995\% compressed air (Messer). The carrier gas was 99.995\% $\mathrm{N}_{2}$ (Messer). Each measurement was carried out with $0.1 \mu \mathrm{l}$ sample volume, injected with a $5 \mu$ l syringe. The results from GC measurements were calculated by the integration of the chromatogram.

\section{- Ultraviolet-Visible spectroscopy (UV-Vis)}

The electron excitation measurements were performed on a Shimadzu 1650-PC UV-Vis two-way spectrophotometer. Each measurement was recorded in a $10 \mathrm{~mm}$ quartz cuvette (Hellma) between $200-400 \mathrm{~nm}$, with $1 \mathrm{~nm}$ resolution and $4 \mathrm{~nm} / \mathrm{sec}$ scan speed. The reference was HPLC grade EtOAc in every case.

\section{- Infrared spectroscopy (IR)}

The infrared (IR) measurements were carried out on a Bio-Rad FTS 60-A FT-IR spectrometer. Each spectrum was collected between $4000-400 \mathrm{~cm}^{-1}$ with $4 \mathrm{~cm}^{-1}$ resolution and 256 accumulations. For the $\alpha$ - thienyl substituted cinnamic acids and for the E32P, E33P, E34P and E2Ph33P molecules, the spectra collected in solution as well using $\mathrm{NaCl}$ cuvettes with different light path lengths (the solvent was DMSO or chloroform, and the absorption bands of the solvent are removed from the spectra DMSO: $2900-3000^{-1} \mathrm{~cm}, 1460-1380 \mathrm{~cm}^{-1}, 1100-925 \mathrm{~cm}^{-1}$, chloroform: due to the very low absorptions of it, there is no need to remove the absorption bands). The solid samples measured utilizing the attenuated total reflection (ATR) mode, using a HarrickMeridian split-PEA diamond ATR head and a liquid nitrogen cooled MCT detector with $20 \mathrm{kHz}$ scanning speed. Each spectrum was baseline-corrected, and due to the vibrations of the diamond $C-C$ bonds, the $2200-2000 \mathrm{~cm}^{-1}$ region was removed from every spectrum. On using other molecules, the "classic" pastille method was applied, where the sample is mixed and encapsulated with $\mathrm{KBr}$ using $1 \mathrm{wt} \%$ of the sample molecule and 256 scan were collected using a DTGS detector.

\section{- Nuclear magnetic resonance (NMR)}

Nuclear magnetic resonance (NMR) measurements were performed on a Bruker Avance 500, $500 \mathrm{MHz}$ spectrometer. For the ${ }^{1} \mathrm{H}$ and ${ }^{31} \mathrm{P}$ spectra, 128 scans were collected. The ${ }^{1} \mathrm{H}^{-1} \mathrm{H}$ Correlation Spectra (COSY) measured with $1024 \times 512$ resolution and 16 to 64 scans were accumulated. The nuclear Overhauser effect spectroscopic 
(NOESY) and heteronuclear single quantum coherence (HSQC) results were gained with the same parameters as was described for COSY. Each measurement was performed in deuterated solvents (described in the materials section) in Wilmad, $5 \mathrm{~mm}, 500 \mathrm{MHz}$ NMR tubes at atmospheric pressure and $298 \mathrm{~K}$ temperature. Each spectrum was baseline- and phase-corrected. The $\mathrm{t} 1, \mathrm{t} 2$ noise and the contaminants, like solvent peaks or impurities are removed from the 2D NMR spectra to simplify the images.

\section{- X-ray diffractometry (XRD)}

Powder X-ray diffraction (XRD) patterns of the solid samples were registered in the $2 \Theta=3-35^{\circ}$ region on Rigaku Miniflex II and DRON-2 instruments, using CuK $\alpha(\lambda=$ $1.5418 \AA$ A ) radiations in Bragg-Brentano geometry. Reflection positions were determined via fitting a Gaussian function. They were found to be reproducible within $0.05^{\circ}(2 \Theta)$.

\section{- Melting Point (mp)}

The melting points of the solid materials (if the melting points cannot be found in the literature) are determined on an SRS Optimelt MTA100, automatic melting point measuring system, which uses the capillary glass tube method with optical analysis. Each measured or cited melting point data are in ${ }^{\circ} \mathrm{C}$.

\subsubsection{Surface inspection techniques}

- Infrared Microspectroscopy (IRM):

The IRM technique was applied for the characterization of the adsorbed molecules on gold and silver surfaces (created by the PLD method). The measurements were carried out on a Bruker Vertex 70 IRM instrument, collecting the spectra in total reflection mode from the focused area of the proper surface (1-0.1 $\mathrm{mm}^{2}$ ). A liquid nitrogen cooled MCT detector was used to collect observable intensities. Each spectrum was created from 1024 accumulated scans with $2 \mathrm{~cm}^{-1}$ resolution in the $4000-400 \mathrm{~cm}^{-1}$ region.

\section{- Scanning Electron Microscopy (SEM)}

The metal layers created via the PLD technique were inspected with scanning electron microscopy, to determine the homogeneity of the surface at the atomic level. The instrument used for the characterization was a Hitachi S-4700 device with varying accelerating voltages. The samples were fixed and grounded with a copper tape.

- Atomic Force Microscopy (AFM) 
The topology of the adsorbed molecular layers on gold and silver surfaces was studied by atomic force microscopy using an NT-MDT Solver AFM microscope working in the "tapping" mode (the frequency of the cantilever was $278 \mathrm{kHz}$ ). The AFM needle (manufactured by Nanosensors, Inc.) was an SSS-NCH-type $15 \mu \mathrm{m}$ long silicon needle with $10^{\circ}$ half cone angle and $2 \mathrm{~nm}$ radius of curvature.

\subsubsection{Reactors and preparative instruments}

\section{- Microwave reactor system (MW)}

For the microwave-assisted reactions, a CEM Focused Microwave System (Model Discover SP) was applied. The system runs at $300 \mathrm{~W}$, and the temperature was kept under max. $90^{\circ} \mathrm{C}$ for varying times, using a $100 \mathrm{ml}$ rbf. equipped with an air-cooled condenser (open vessel method).

\section{- UV-irradiated reactor (UV)}

For the UV induced isomerization experiments, a semi-continuous UV-irradiated flow reactor was designed. The isomerization reactor was a standard $10 \mathrm{~mm}(4 \mathrm{ml})$, four-sided quartz cuvette with a Teflon plug (Hellma). The cuvette was attached to a 12 V DC membrane pump M1 (ASF Thomas D-8217) and two $100 \mathrm{ml}$ glass buffer vessels via Teflon tubing ( $3 \mathrm{~mm}$ external and $2 \mathrm{~mm}$ internal diameter). The flow of the treated solution was controlled by an electronic circuit based on an ATTINY 2313-P microcontroller unit (MCU) fed by stabilized $5 \mathrm{~V}$ power supply and the EEPROM programmed with an AVR-ISP MK II USB-programmer interface. All components of the electronic circuit are class I. electronic products (1\% metal layer resistors: R1-R3-R4, high quality ceramic capacitor: $\mathbf{C 1}$ and class I. trimmer potentiometer: R2). The MCU drives an IRFZ 24N MOSFET Q1, which switches on and off the pump at the proper time (Figure 26). The UV-source was a mercury-vapor lamp (Osram, T5 germicide light-tube, $135 \mathrm{~mm}, 4 \mathrm{~W}, \mathrm{G} 5$ ) with an emission maximum at $254 \mathrm{~nm}$. The maximum power at the emission line was $1 \mathrm{~W}$. Each isomerization reaction was carried out in HPLC grade EtOAc (99.9\%). The concentration of the treated solution was $0.05 \mathrm{M}$ in all cases to avoid the formation of unwanted side products.

The schematics of the flow reactor and the electronic circuit are shown in Figure 26 and Figure 27. 


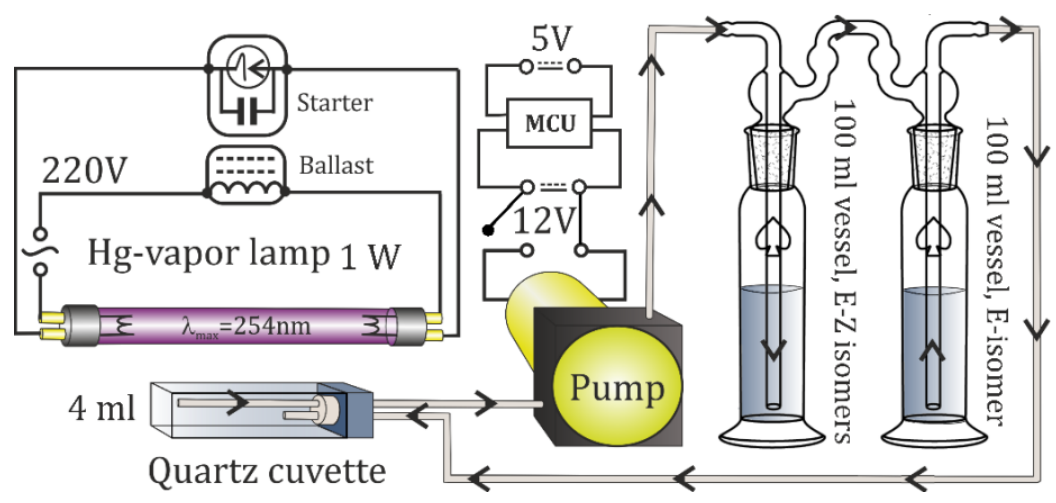

Figure 26 The schematic of the automated semi-continuous UV flow reactor

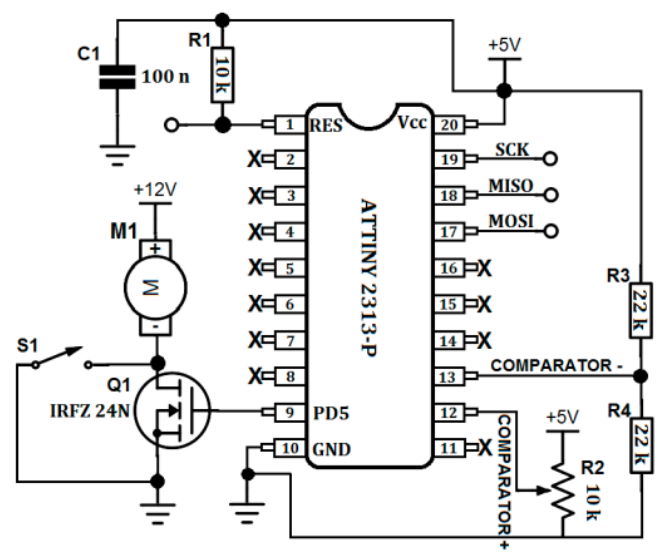

Figure 27 The circuit scheme of the flow controller unit

The $\mathrm{C}$ source code of the controller, driving the MCU, can be found in the Appendix.

\subsection{General methods for the stereoselective synthesis of $E$-cinnamic acids}

The short description of the tested methods will communicated in the following.

\subsubsection{Preparation of 2-selenophenylcarboxaldehyde with Vilsmeier-Haack formylation}

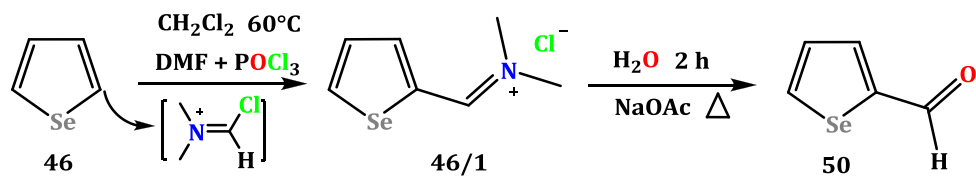

Figure 28 Formylation of selenophene (46) with the Vilsmeier-Haack method

The preparation of 2-selenophenecarboxaldehyde $\mathbf{5 0}$ was carried out with optimized Vilsmeyer-Haack formylation. 1 eq. 46 dissolved in dichloromethane, then cooled, and 1 eq. of DMF and $\mathrm{POCl}_{3}$ were added. The mixture was heated to $65^{\circ} \mathrm{C}$ in a sealed bottle for 1 hour; then, refluxed with aqueous sodium acetate for additional 2 
hours. The reaction mixture was extracted with dichloromethane dried over sicc. $\mathrm{MgSO}_{4}$, and then evaporated. The residue was vacuum-distilled at $100 \mathrm{mbar}$, and the fraction between $90-100^{\circ} \mathrm{C}$ was collected as colorless oil, which was $\mathbf{5 0 , 6 5 \%}$ of the theoretical yield (99\%, GC). The preparation of the 3-selenophenecarboxaldehyde was skipped due to the too many reaction steps needed requiring high amount of selenophene 46 , which is a highly toxic and expensive compound.

\subsubsection{Preparation of E-cinnamic acid with the Perkin condensation}

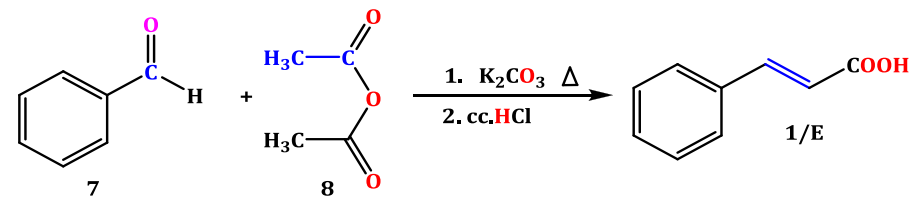

Figure 29 Preparation of E-cinnamic acid with Perkin condensation

The reaction was carried out with the condensation of acetic anhydride $\mathbf{8}$ and benzaldehyde 7 in the presence of $\mathrm{K}_{2} \mathrm{CO}_{3}$ with gentle heating for $2 \mathrm{~h}$, following the literature method. ${ }^{124}$ The mixture diluted with $\mathrm{KOH}$ solution, extracted with diethyl ether and the aqueous phase was acidified. The precipitate was filtered off and dried. The isolated yield was 81-92\%. The solid material was recrystallized from $\mathrm{MeOH}: \mathrm{H}_{2} \mathrm{O}$ (1:3) applying activated charcoal. The product was pure $\mathbf{1 / E}\left(99 \%,{ }^{1} \mathrm{H}\right.$ NMR). ${ }^{126}$

\subsubsection{Preparation of E-ethylcinnamate with the Claisen-Schmidt condensation}

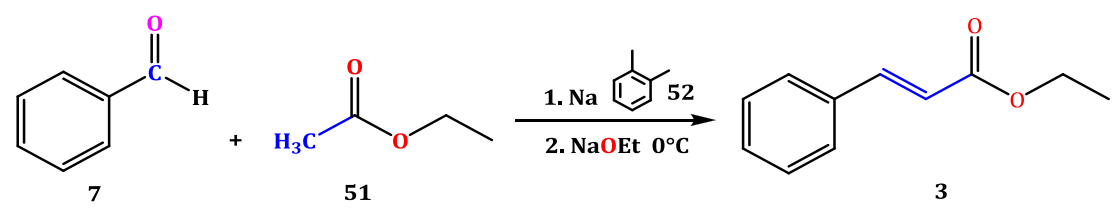

Figure 30 Preparation of E-cinnamic acid with Claisen-Schmidt condensation

The Claisen condensation was performed with a general method. ${ }^{127}$ Clear sodium, melted in o-xylene $\mathbf{5 2}$ and parsed into small particles; then, the solvent changed to EtOAc 51, containing catalytic EtOH. The mixture cooled to $0^{\circ} \mathrm{C}$ and benzaldehyde 7 was added dropwise. After all sodium reacted, EtOAc distilled off and the residue was vacuumdistilled under 100 mbar, the fraction between $180-190^{\circ} \mathrm{C}$ was collected as a colorless liquid, which was pure E-ethylcinnamate 3. Yield: $60-65 \%(98 \%, \mathrm{GC})$. The ${ }^{1} \mathrm{H}$ NMR spectrum correlates well with the literature data. ${ }^{128}$ 


\subsubsection{Preparation of diethyl-2-benzylidene malonate with the Knövenagel condensation}

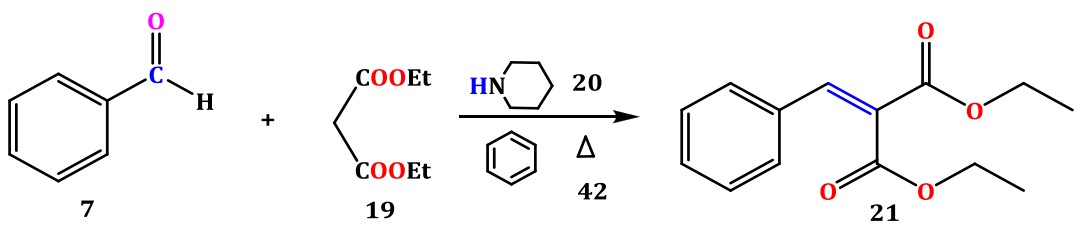

Figure 31 Preparation of diethyl-2-benzylidene malonate with the Knövenagel condensation

The preparation was carried out on a Dean-Stark water trap. ${ }^{129}$ Diethyl malonate 19, commercial benzaldehyde 7 (commercial benzaldehyde contains a few percent of benzoic acid, which is necessary for the reaction to work), catalytic amount of piperidine 20 and benzene $\mathbf{4 2}$ were refluxed for $10 \mathrm{~h}$, until no more water was formed. The volatiles were removed with distillation and the residue was vacuum-distilled at 100 mbar, and the fraction between $220-230^{\circ} \mathrm{C}$ was collected as a light yellow oil (21). ${ }^{130}$ Yield: $85-87 \%$ (98\%, GC). The ${ }^{1} \mathrm{H}$ NMR verified the structure of $\mathbf{2 1 . 1 3 1}$

\subsubsection{Microwave-assisted Knövenagel-Döbner condensation procedures}

The microwave adaptation of the Döbner reactions was a promising method, which could shorten the reaction time very effectively.

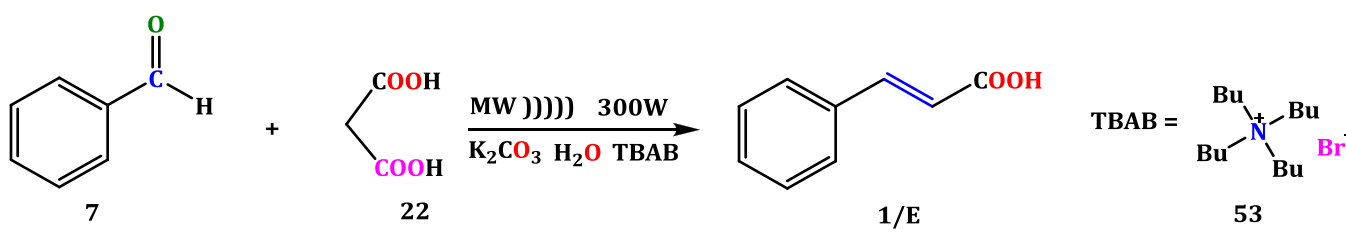

Figure 32 Microwave-assisted Knövenagel-Döbner condensation

1 eq. benzaldehyde 7,1 eq. of malonic acid $22,0.5$ eq. $\mathrm{K}_{2} \mathrm{CO}_{3}, 0.5$ eq. of tetrabutyl ammonium bromide $\mathbf{5 3}$ and distilled water (energy transfer material) are placed in a rbf., attached to an air-cooled reflux condenser. The reaction mixture was irradiated with microwave at $300 \mathrm{~W}$ for $15 \mathrm{~min}$, using automated pulse sequence and nitrogen stream to keep the temperature at max. $90^{\circ} \mathrm{C}$. The mixture was left to cool down; then, diluted with $10 \% \mathrm{KOH}$. It was extracted with diethyl ether, and the combined aqueous phases were treated with $\mathrm{cc}$. $\mathrm{HCl}$, until it was strongly acidic to litmus. The precipitated crystals $(\mathbf{1} / \mathbf{E})$ were filtered, washed with water and recrystallized from $\mathrm{MeOH}: \mathrm{H}_{2} \mathrm{O}$ (1:3). The yield varied from $60-87 \%$ with $99 \%$ purity (1H NMR); thus, the method provided with lower yield than the classic methods, and required expensive phase transfer catalyst. 


\subsubsection{Preparation of E-cinnamic acid with the Knövenagel-Döbner condensation}<smiles>O=Cc1ccccc1</smiles><smiles>O=C(O)CC(=O)O</smiles>

22<smiles>Oc1ccccc1OCc1cccnc1</smiles><smiles>O=C(O)/C=C/c1ccccc1</smiles>

Figure 33 Preparation of E-cinnamic acid with Knövenagel-Döbner condensation

Malonic acid 22 was placed and dissolved in pyridine 43 at $50^{\circ} \mathrm{C}$. After all malonic acid was dissolved, catalytic amount of piperidine $\mathbf{2 0}$ was added, and the solution was stirred for 15 min. Traces of hydroquinone $\mathbf{5 4}$ was also added to the solution. Purified benzaldehyde 7 was added dropwise; then, the mixture was stirred for an additional 20 min, and then the temperature was raised to reflux $\left(110^{\circ} \mathrm{C}\right)$ for $1-5$ hour to complete decarboxylation. The cooled mixture was acidified and the precipitated E-cinnamic acid 1/E was filtered and washed. The crude product was purified by recrystallization from $\mathrm{MeOH}: \mathrm{H}_{2} \mathrm{O}$ (1:3) and decolorized with activated charcoal. ${ }^{24}$ Yield: white crystals, 95-100\% (99\%, ${ }^{1} \mathrm{H}$ NMR). The ${ }^{1} \mathrm{H}$ NMR spectrum is the same as for the other E-cinnamic acid 1/E samples.

4.3.7 Preparation of E-3-(2 or 3-furyl-, 2 or 3-thienyl-, 2, 3 or 4-pyridyl- and 2selenophenyl)propenoic acids with the Knövenagel-Döbner condensation

The preparation of the E-heteroaryl propenoic acids are the same as applied in section 4.3.6. The pyridyl derivatives were treated a bit differently, due to the basic characteristics of the pyridine ring. Pyridine $\mathbf{4 3}$ was evaporated on a rotary evaporator and the residue was diluted with diethyl ether; then, filtered and washed with ice-cold water. The prepared heteroaryl derivatives are shown in Table 1 . The ${ }^{1} \mathrm{H}$ NMR spectra of the products show full consistency with the structures of each derivative; thus, the syntheses of the desired materials were successful in all cases and each derivative was the pure $E$ isomer. 


Reaction
time

Table 1 Synthetic parameters and results for the E-3-heteroaryl propenoic acid preparation with Knövenagel-Döbner method

\subsubsection{Solubilities of cinnamic acid derivatives in DMSO}

The solubilities of the E-cinnamic acid derivatives were determined by gravimetry at $25^{\circ} \mathrm{C}$ in DMSO (spectroscopic grade) for NMR spectroscopy measurements. The results are listed in Table 2.

\begin{tabular}{ccc}
\hline Compound & Solubility (g/l) & Solubility (M) \\
\hline E32F & $1671 \pm 14$ & $12.1 \pm 0.1$ \\
E33F & $1022 \pm 12$ & $7.4 \pm 0.1$ \\
E32T & $1526 \pm 15$ & $9.9 \pm 0.1$ \\
E33T & $1095 \pm 11$ & $7.1 \pm 0.1$ \\
E32P & $177 \pm 3$ & $1.19 \pm 0.02$ \\
E33P & $89 \pm 1$ & $0.6 \pm 0.01$ \\
E34P & $51 \pm 1$ & $0.34 \pm 0.01$ \\
E32S & $123 \pm 6$ & $0.61 \pm 0.03$ \\
E2Ph33P & $550 \pm 11$ & $2.44 \pm 0.05$ \\
E23T33T & $739 \pm 4$ & $3.12 \pm 0.02$ \\
\hline
\end{tabular}

Table 2 Solubilities in DMSO at $25^{\circ} \mathrm{C}$ 


\subsubsection{Preparation of octyl-E-3-(2-thienyl)propenoate and octyl-E-3-(3-}

\section{thienyl)propenoate}

To determine the orientation of the self-assembled layers, the octyl esters of the thienyl monosubstituted derivatives were chosen as model compounds, due to the unreactive, long alkyl-chain, preventing the formation of hydrogen-bonded dimers.

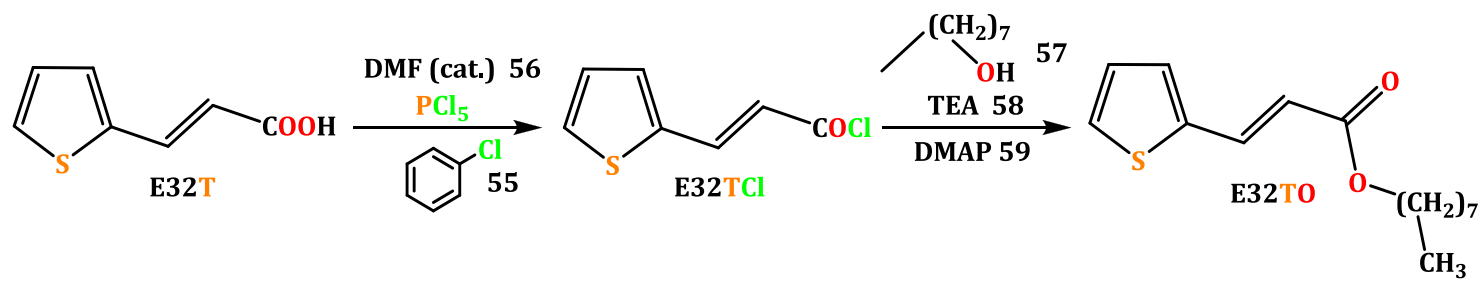

Figure 34 The esterification of E32T and E33T with n-octanol (57)

1 eq. of E32T or E33T was dissolved in $\mathbf{5 5}$ and the solution was cooled to $0^{\circ} \mathrm{C} .1$ eq. $\mathrm{PCl}_{5}$ was added in one portion. The system was equipped with a water trap and intensely stirred until the evolution of $\mathrm{HCl}$ stopped; then, the temperature was raised to $100^{\circ} \mathrm{C}$ and was kept there for $2 \mathrm{~h}$. The resulting dark solution was evaporated in vacuo, and the black residue, which was either E-3-(2-thienyl)propenoyl chloride E32TCl or E-3(3-thienyl)propenoyl chloride E33TCl, was used without further purification. 1 eq. $n$ octanol 57 and 4 eq. TEA was dissolved in dichloromethane and catalytic amount of DMAP 59 was added, then the mixture cooled down to $0^{\circ} \mathrm{C} .1$ eq. of E32TCl or the E33TCl was dissolved in dichloromethane; then, it was added to the stirred solution dropwise, and the mixture was stirred for an additional $1 \mathrm{~h}$, at $\mathrm{rt}$. The resulting mixture was washed with brine and extracted with dichloromethane and dried over sicc. $\mathrm{MgSO}_{4}$. The volatiles were evaporated on a rotary evaporator, and the residue was purified by flash column chromatography on Normasil 60 silica gel: EtOAc-Hexane 1:1 (E32T0: $\mathrm{R}_{\mathrm{f}}=$ 0.88; E33T0: $\mathrm{R}_{\mathrm{f}}=0.81$ ). Yield: $90 \%$ of the theoretical for both derivatives, (purity: $99 \%$ for both derivatives, GC). The structures were verified with ${ }^{1} \mathrm{H}$ NMR spectroscopy. E32T0: ${ }^{1} \mathrm{H}$ NMR $\left(500 \mathrm{MHz}, \mathrm{CDCl}_{3}\right) \delta=0.86-0.89(\mathrm{t}, \mathrm{J}=7.1 \mathrm{~Hz}, 3 \mathrm{H}), 1.27-1.38(\mathrm{~m}, 8 \mathrm{H})$, 1.67-1.69 (quint, $\mathrm{J}=7.3 \mathrm{~Hz}, 2 \mathrm{H}$ ), 4.16-4.19 (t, J = 6.7 Hz, 2H), 6.24-6.27 (d, J = $15.8 \mathrm{~Hz}$, 1H), 7.27-7.28 (d, J = 4.8 Hz, 1H), 7.30-7.32 (dt, JA $\left.=4.5 \mathrm{~Hz}, \mathrm{~J}_{\mathrm{B}}=2.4 \mathrm{~Hz}, 1 \mathrm{H}\right), 7.47$ (d, J $=2.3 \mathrm{~Hz}, 1 \mathrm{H}), 7.64-7.67(\mathrm{~d}, \mathrm{~J}=15.8 \mathrm{~Hz}, 1 \mathrm{H})$. E33T0: ${ }^{\mathbf{1}} \mathbf{H} \mathbf{N M R}\left(500 \mathrm{MHz}, \mathrm{CDCl}_{3}\right) \delta=$ 0.87-0.89 (t, J = 7.0 Hz, 3H), 1.28-1.39 (m, 8H), 1.66-1.70 (quint, $J=6.7 \mathrm{~Hz}, 2 \mathrm{H}$ ), 
4.17-4.19 (t, J = 6.7 Hz, 2H), 6.24-6.28 (d, J=15.6 HZ, 1H), 7.28-7.29 (d, J = 4.9 Hz, 1H), 7.31-7.32 (d, J = 4.7 Hz, 1H), 7.48 (s, 1H), 7.64-7.69 (d, J =15.8 Hz, 1H).

\subsection{General methods for the synthesis of $E$-Z-cinnamic acid isomer mixtures}

4.4.1 Preparation of E-Z cinnamic acid isomer mixtures via UV induced photoisomerization and the kinetics of the process

The molar absorptivity constant $\left(\varepsilon\left(\mathrm{M}^{-1} \mathrm{~cm}^{-1}\right)\right)$ determined for each E-cinnamic acid and for some of the disubstituted derivatives as well, at the wavelength belongs to the absorbance maximum, at $25^{\circ} \mathrm{C}(298 \mathrm{~K})$ in EtOAc (99.9\% Sigma-Aldrich, HPLC grade) in a $10 \mathrm{~mm}$ quartz cuvette (Hellma). The proper solutions diluted until their absorptions reach approximately the 0.8-1.3 absorbance value, where the Beer-Lambert equation is still valid and linear (Table 3). The isomerization experiment was performed with the same equipment in EtOAc, using the $0.05 \mathrm{M}$ solution of the studied isomer. The process was followed with ${ }^{1} \mathrm{H}$ NMR spectroscopy (UV-Vis spectroscopy could not be applied due to the overlapping absorption bands of the isomers). The solutions were irradiated using the UV-reactor setup (4.2.3) for different time frames $(15 \mathrm{~min}, 30 \mathrm{~min}, 1 \mathrm{~h}, 2 \mathrm{~h}, 4 \mathrm{~h}, 8 \mathrm{~h}$, $12 \mathrm{~h}, 24 \mathrm{~h}, 48 \mathrm{~h}$ ) and the isomer distribution was calculated with the relative integration of the peaks of the olefinic protons. The results (which are very close to the equilibrium isomer distribution) are shown in the last column of Table 3.

\begin{tabular}{cccccc}
\hline Compound & $\mathbf{C ( M )}$ & $\lambda_{\max }(\mathbf{n m})$ & $\boldsymbol{\varepsilon}\left(\mathbf{M}^{-1} \mathbf{c m}^{-1}\right)$ & $Z: E$ ratio $(\mathbf{2 4 h})$ & Kequilibrium \\
\hline E32F & $3.62 \mathrm{E}-05$ & 298 & 22652 & $29: 71$ & 0.40 \\
E33F & $7.24 \mathrm{E}-05$ & 271 & 13149 & $35: 65$ & 0.53 \\
E32T & $6.49 \mathrm{E}-05$ & 305 & 16884 & $30: 70$ & 0.42 \\
E33T & $6.49 \mathrm{E}-05$ & 276 & 19783 & $66: 34$ & 1.94 \\
E32P & $6.70 \mathrm{E}-05$ & 287 & 13926 & $87: 13$ & 6.69 \\
E33P & $6.44 \mathrm{E}-05$ & 279 & 16935 & $13: 87$ & 0.15 \\
E34P & $5.90 \mathrm{E}-05$ & 257 & 23220 & $2: 98$ & 0.02 \\
E32S & $1.24 \mathrm{E}-04$ & 318 & 7890 & $42: 58$ & 0.72 \\
1/E & $6.75 \mathrm{E}-05$ & 272 & 19556 & $58: 42$ & 1.38 \\
Z32F & $7.24 \mathrm{E}-05$ & 299 & 14516 & N/A & N/A \\
Z32T & $8.11 \mathrm{E}-05$ & 306 & 16221 & N/A & N/A \\
E2Ph33P & $4.43 \mathrm{E}-05$ & 260 and 285 & 10632 & $8: 92$ & 0.08 \\
E23T33T & $4.21 \mathrm{E}-05$ & 287 & 14180 & $60: 40$ & 1.51 \\
\hline
\end{tabular}




\subsection{General methods for the stereoselective synthesis of $Z$-cinnamic acids}

\subsubsection{Preparation of 3-phenylpropiolic acid and methyl 3-phenylpropiolate}

3-phenylpropiolic acid 26 and methyl 3-phenylpropiolate $\mathbf{6 0}$ were used as model compounds to optimize the Z-selective hydrogenation with Lindlar's catalyst. The selected synthetic role can be seen on Figure 35.

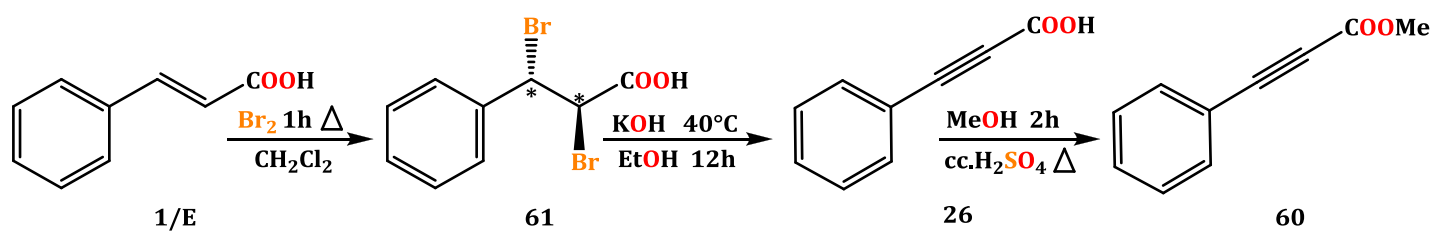

Figure 35 The preparation role of 3-phenylpropiolic acid (26) and its methyl ester (60) from E-cinnamic $\operatorname{acid}(\mathbf{1} / \mathbf{E})$

Preparation of (2R, 3S)-dibromo-3-phenylpropanoic acid 61: 1 eq. of E-cinnamic acid was dissolved in dichloromethane and 1.05 eq. bromine in dichloromethane was added and the mixture was refluxed and stirred for $1 \mathrm{~h}$. The result was cooled to $0^{\circ} \mathrm{C}$ and the precipitated crystals were filtered off and washed with ice cold dichloromethane. ${ }^{136}$ The product is a white crystalline material 61 . Yield: $90 \%$ of the theoretical $\left(99 \%,{ }^{1} \mathrm{H}\right.$ NMR). The structure of $\mathbf{6 1}$ was consistent with the spectrum*.

Preparation of 3-phenylpropiolic acid 26: 1 eq. of crude 61 was added to a solution of 4 eq. $\mathrm{KOH}$ in $96 \%$ aqueous ethanol. The solution should be kept under $40^{\circ} \mathrm{C}$ during the addition. Then, the mixture was stirred overnight $(8 \mathrm{~h})$ at $40^{\circ} \mathrm{C}$. The resulting brown solution was filtered and the filtrate was treated with $\mathrm{cc} . \mathrm{HCl}$ until it became acidic to litmus; then, the precipitated crystals were filtered off again. The ethanol was distilled off the filtrate, and the resulted solution was mixed with the separated salts and the solution was treated with $20 \% \mathrm{H}_{2} \mathrm{SO}_{4}$. The precipitated crystals were filtered off and washed with cold water. The crude product was recrystallized from $\mathrm{MeOH}: \mathrm{H}_{2} \mathrm{O}$ (1:3) and was decolorized with activated charcoal. The product is a yellow crystalline material with pleasant smell $\mathbf{2 6}^{137}$. Yield: $75 \%$ of the theoretical (95\%, ${ }^{1} \mathrm{H}$ NMR). The structure was consistent with the spectrum. ${ }^{138}$

Preparation of methyl 3-phenylpropiolate 60: 1 eq. 26 was dissolved in 10 eq. $\mathrm{MeOH}$ and catalytic amount of $\mathrm{cc} \cdot \mathrm{H}_{2} \mathrm{SO}_{4}$ was added while the solution was intensely swirled. 
The solution was refluxed for 5 hours. The methanol was evaporated; then, the residue was washed with $5 \% \mathrm{Na}_{2} \mathrm{CO}_{3}$ solution, and was extracted with diethyl ether. The combined organic phases were dried over sicc. $\mathrm{MgSO}_{4}$; then, the ether was evaporated. The residue was vacuum-distilled at $100 \mathrm{mbar}$, and the fraction between $140-160{ }^{\circ} \mathrm{C}$ was collected as yellow oil 60, which had pleasant smell. ${ }^{139}$ Yield: $60 \%$ of the theoretical $(98 \%, \mathrm{GC})$.

Preparation of the Lindlar's catalysts: The fundamental Lindlar's catalyst $(5 \% P d$ on $\mathrm{CaCO}_{3}$, conditioned with $\mathrm{Pb}^{2+}$ ions) is commercially available; however, the preparation is uncomplicated; therefore, the catalyst was prepared using two different catalyst supports $\left(\mathrm{CaCO}_{3}\right.$ and $\left.\mathrm{BaSO}_{4}\right)$.

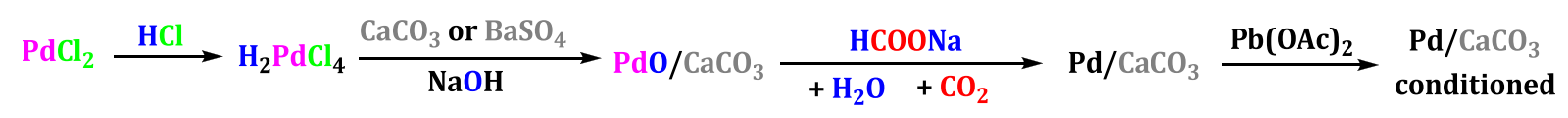

Figure 36 The preparation of conditioned Lindlar's catalyst from palladium(II) chloride

$\mathrm{PdCl}_{2}$ was dissolved in $\mathrm{cc} . \mathrm{HCl}$. The resulting $\mathrm{H}_{2} \mathrm{PdCl}_{4}$ solution was diluted with water and the $\mathrm{pH}$ was brought to $4.0-4.5$ by $3 \mathrm{M} \mathrm{NaOH}$. Precipitated calcium carbonate (or $\mathrm{BaSO}_{4}$ ) was added to the solution. The well-stirred suspensions were heated to 75$85^{\circ} \mathrm{C}$ and were held at this temperature until all the palladium was precipitated. HCOONa solution (about $0.7 \mathrm{M}$ ) was added, and the reduction was completed by stirring the mixtures at $75-85^{\circ} \mathrm{C}$ for $40 \mathrm{~min}$. The catalysts, which were black now, were separated and were washed multiple times with water. The wet catalysts were suspended in water again and 0.25 eq. $20 \% \mathrm{~Pb}(\mathrm{OAc})_{2}$ solution was added. The slurries were stirred and heated at $75-85^{\circ} \mathrm{C}$ for $45 \mathrm{~min}$. The catalysts were separated and washed with water, and dried in an oven at $60-70^{\circ} \mathrm{C}$. The dried catalysts, were dark grey powders $\left(5 \% \mathrm{Pd}\right.$ on $\mathrm{CaCO}_{3}$ and $\left.\mathrm{BaSO}_{4}\right) .{ }^{140}$

\subsubsection{Z-selective hydrogenation of 3-phenylpropiolic acid with Lindlar's catalyst}

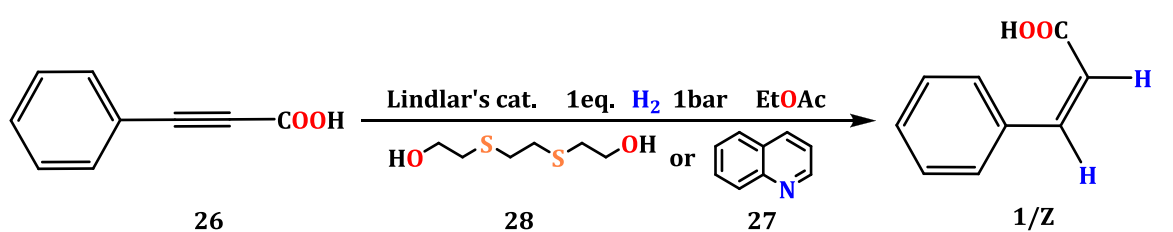

Figure 37 Z-selective hydrogenation of (26) with Lindlar's catalyst under different conditions 
1 eq. of 3-phenylpropiolic acid $\mathbf{2 6}$ was dissolved in EtOAc; then, was placed in a hydrogenation apparatus (Figure 38). Lindlar's catalyst $\left(5 \%, \mathrm{Pd} / \mathrm{CaCO}_{3}\right.$ or $\left.\mathrm{Pd} / \mathrm{BaSO}_{4}\right)$ and 0.1 eq. quinoline 27 or 3,6-dithia-1,8-octanediol 28 were added to the mixture. The apparatus was evacuated; then, was refilled with $\mathrm{H}_{2}$ (1 bar); then, stirring was started. If the first equivalent of $\mathrm{H}_{2}$ absorbed the reaction was stopped to avoid perhydrogenation. The catalyst was filtered off, and the residue was concentrated in vacuo; then, was diluted with diethyl ether, and washed with $10 \% \mathrm{HCl}$ solution. The organic phase was separated; then, dried over sicc. $\mathrm{MgSO}_{4}$, and the ether was removed on a rotary evaporator. ${ }^{141}$ The residue was a brown oily mixture, containing several derivatives. The results are listed in Table 4.

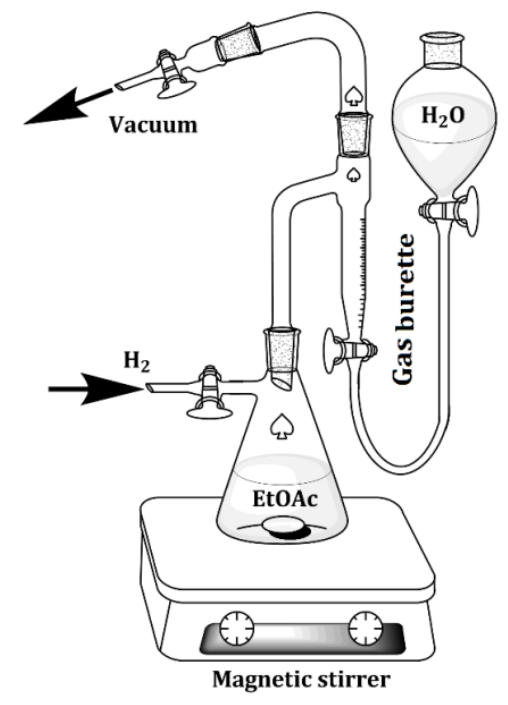

Figure 38 The hydrogenation apparatus

\begin{tabular}{cccc}
\hline Catalyst & Poison & Yield & Z:E ratio \\
\hline $\begin{array}{c}\mathrm{Pd} / \mathrm{CaCO}_{3} \\
\left(\mathrm{~Pb}^{2+}\right)\end{array}$ & $\mathbf{2 7}$ & $85-95 \%$ & $90: 10$ \\
$\begin{array}{c}\mathrm{Pd} / \mathrm{CaCO}_{3} \\
\left(\mathrm{~Pb}^{2+}\right)\end{array}$ & $\mathbf{2 8}$ & $80-92 \%$ & $95: 5$ \\
$\begin{array}{c}\mathrm{Pd} / \mathrm{BaSO}_{4} \\
\left(\mathrm{~Pb}^{2+}\right)\end{array}$ & $\mathbf{2 7}$ & $85 \%$ & \\
$\mathrm{Pd} / \mathrm{BaSO}_{4}$ & & & $92: 8$ \\
$\left(\mathrm{~Pb}^{2+}\right)$ & $\mathbf{2 8}$ & $87 \%$ & $94: 6$ \\
\hline
\end{tabular}

Table 4 Results for the different hydrogenation variants 


\subsubsection{Utilizing the HWE synthesis for Z-selective preparation}

\subsubsection{Preparation of the different HWE phosphonates}

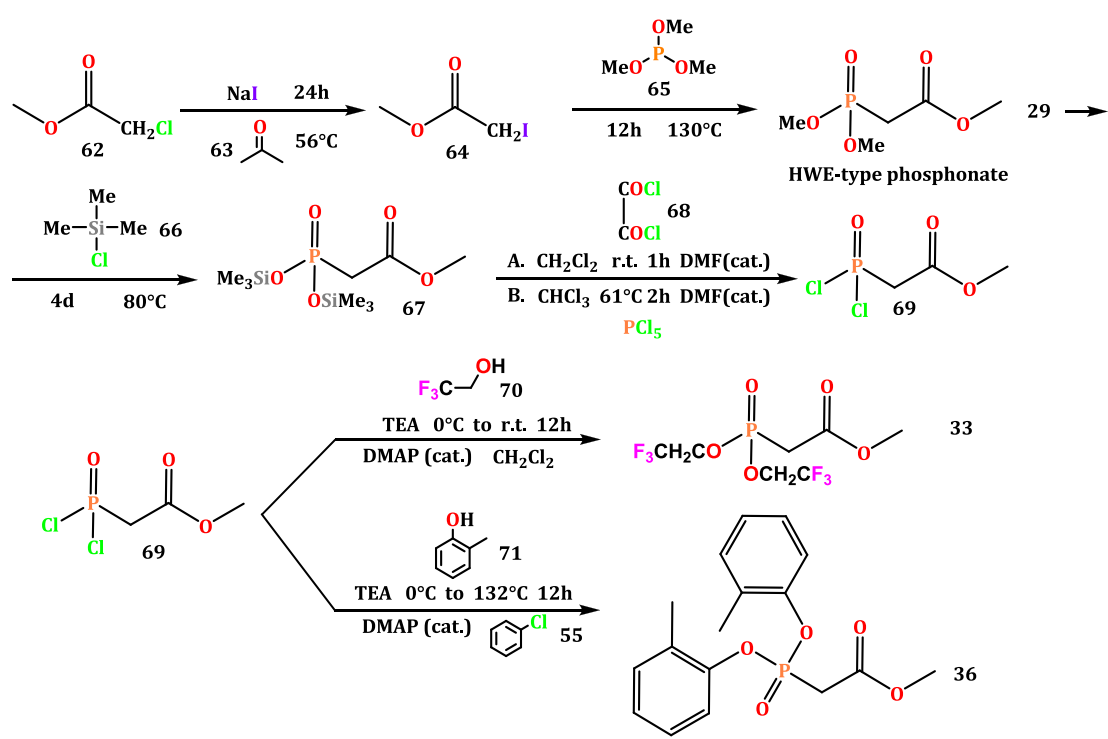

Figure 39 Reaction role to the $Z$-selective reagents $(33,36)$

Preparation of methyl iodoacetate: 1 eq. of 62 was dissolved in acetone 63 and 1 eq. sicc. NaI was added. The mixture was vigorously stirred and refluxed for $24 \mathrm{~h}$. After the appropriate time elapsed, the precipitated salts were filtered off, and the filtration was evaporated. The dark brown residue was washed with $5 \% \mathrm{Na}_{2} \mathrm{~S}_{2} \mathrm{O}_{3}$ solution, and then extracted with diethyl ether. The combined organic phases were dried over sicc. $\mathrm{MgSO}_{4}$; then, the volatiles were removed. The residue vacuum distilled at 100 mbar and the fraction between $60-65^{\circ} \mathrm{C}$ was collected as a colorless, highly irritative liquid, which is 64. ${ }^{142}$ Yield: $80 \%$ of the theoretical $(96 \%, G C)$.

Preparation of trimethyl phosphonoacetate 29 with Michaelis-Arbuzov reaction: 1 eq. 64 and 2 eq. trimethyl phosphite 65 were refluxed at $110-130^{\circ} \mathrm{C}$ for $12 \mathrm{~h}$. The excess of 65 was removed; then, the residue was vacuum-distilled at $100 \mathrm{mbar}$, and the fraction between $120-128^{\circ} \mathrm{C}$ was collected as a colorless oily compound, which is $29 .{ }^{143}$ Yield: $91 \%$ of the theoretical $(93 \%, \mathrm{GC})$.

Preparation of methyl bis(trimethylsilyl)phosphonoacetate 67: 1 eq. of 29 and 5 eq. trimethylsilyl chloride 66 were placed in a screw-cap Pyrex bottle, equipped with a pressure meter. The temperature was raised slowly to $80^{\circ} \mathrm{C}$, while the pressure was monitored and kept under 3 bars to avoid explosion. When the temperature and the 
pressure were stabilized, the mixture was kept at $80^{\circ} \mathrm{C}$ for 4 days. The volatiles were removed under reduced pressure, and the residue was vacuum-distilled at 100 mbar. The fraction between $142-144^{\circ} \mathrm{C}$ was collected as colorless oil, which was pure $\mathbf{6 7 . 1 4 4}$ Yield: $95 \%$ of the theoretical (93\%, GC).

Preparation of methyl dichloro phosphonoacetate 69: Method A: 1 eq. of 67 was dissolved in $\mathrm{CH}_{2} \mathrm{Cl}_{2}$ and one drop of DMF was added. The system was flushed with argon; then, was cooled to $0^{\circ} \mathrm{C}$. 2.5 eq. of oxalyl chloride 68 was dissolved in $\mathrm{CH}_{2} \mathrm{Cl}_{2}$; then, was added dropwise to the stirred solution. The ice bath was removed, and the solution was stirred for an additional hour. The volatiles were removed under reduced pressure, the residue, which was a yellow oil 69 used in the next step without further purification. ${ }^{144}$ Yield: $96 \%$ of the theoretical (91\%, ${ }^{31}$ P NMR ${ }^{*}$ ). Method B.: 1 eq. 67 was dissolved in chloroform and one drop of DMF was added. 1 eq. of $\mathrm{PCl}_{5}$ was suspended in chloroform and was added dropwise to the cooled solution under vigorous stirring. The temperature was elevated to $60^{\circ} \mathrm{C}$, and was kept for 2 hours. The mixture was cooled and the volatiles were removed under reduced pressure. The residue was a reddish oil 69, which was used without further purification in the following step. ${ }^{145}$ Yield: $97 \%$ of the theoretical $\left(90 \%,{ }^{31} \mathrm{P} \mathrm{NMR}^{*}\right)$.

Synthesis of the Still-Gennari phosphonate 33: A mixture of 6 eq. TEA and 2.5 eq. trifluorethanol 70 was dissolved in $\mathrm{CH}_{2} \mathrm{Cl}_{2}$ and was cooled to $0^{\circ} \mathrm{C}$, and then a small crystal of DMAP was added. The flask was flushed with argon, and a mixture of 1eq. 69 in dichloromethane was added dropwise to the cooled solution under vigorous stirring. The ice bath was removed, and the solution was stirred for additional $12 \mathrm{~h}$. The resulted mixture was washed with brine, and was extracted with $\mathrm{CH}_{2} \mathrm{Cl}_{2}$. The organic layers were combined and dried over sicc. $\mathrm{MgSO}_{4}$, and the volatiles were evaporated in vacuo. The residue, which was a yellow oily material 33, was purified via flash column chromatography on Normasil 60 silica gel, eluted with $n$-hexane-EtOAc, $2: 1 . \mathrm{R}_{\mathrm{f}}=0.61 .144$ Yield: $87 \%$ of the theoretical $\left(95 \%,{ }^{31} \mathrm{P} \mathrm{NMR}^{*}\right)$.

Synthesis of Ando-type phosphonate 36: 2.5 eq. of o-cresol 71 and 6 eq. of TEA were dissolved in $\mathbf{5 5}$ and a catalytic amount of DMAP was added as well. The flask was flushed with $\operatorname{argon}$, and was cooled to $0^{\circ} \mathrm{C}$. 1 eq. of 69 dissolved in 55, and then added dropwise to the well-stirred solution. After the addition the temperature raised to reflux for additional $12 \mathrm{~h}$. The further treatment was the same as was used in the previous 
method. The residue, which was a dark brown oily material 36 was purified via flash column chromatography on Normasil 60 silica gel, eluted with n-hexane-EtOAc, 2:1. $\mathrm{R}_{\mathrm{f}}=0.70$. Yield: $40 \%$ of the theoretical $\left(93 \%,{ }^{31} \mathrm{P} \mathrm{NMR}^{*}\right)$.

4.5.5 Optimization of the Z-selective HWE reaction with Still-Gennari and Ando-type phosphonates

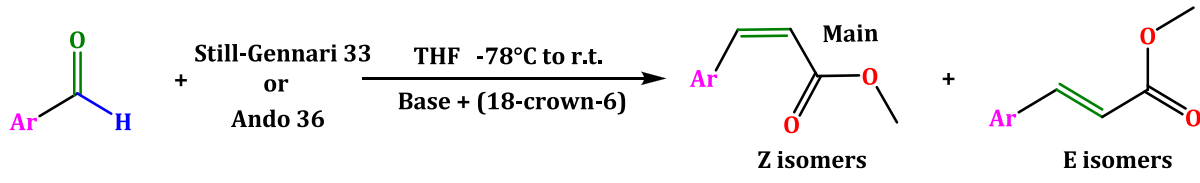

Figure 40 Optimization of the HWE reaction to synthesize Z-cinnamic acids

The general conditions for the optimization: the solvent was water-free THF in each case, combined with 1 eq. of the proper base (NaH, t-BuOK 72, KHMDS 32) and sometimes with an additive (18-crown-6 31), 1 eq. as well. This mixture was injected under vigorous stirring into the cryogenic apparatus (Figure 41), which was flushed with argon, and was cooled from 0 to $-78^{\circ} \mathrm{C}$. After 15 min stirring, 1 eq. of the proper phosphonate was injected. After another 15 min stirring, 1 eq. of the aromatic aldehyde (which was 7 during the optimization) was injected. The mixture was stirred from 5 min to $1 \mathrm{~h}$ at $-78^{\circ} \mathrm{C}$ to $0^{\circ} \mathrm{C}$ or to r.t. for $12 \mathrm{~h}$; then, it was poured into $10 \% \mathrm{NH}_{4} \mathrm{Cl}$ solution to quench the reaction. The residue was washed with brine, and was extracted with EtOAc. The combined organic layers were dried over sicc. $\mathrm{MgSO}_{4}$, and the volatiles were removed on a rotary evaporator. The residue was analyzed with GC and ${ }^{1} \mathrm{H}$ NMR to determine the yield and the isomer distribution. The results are listed in Table 5. 


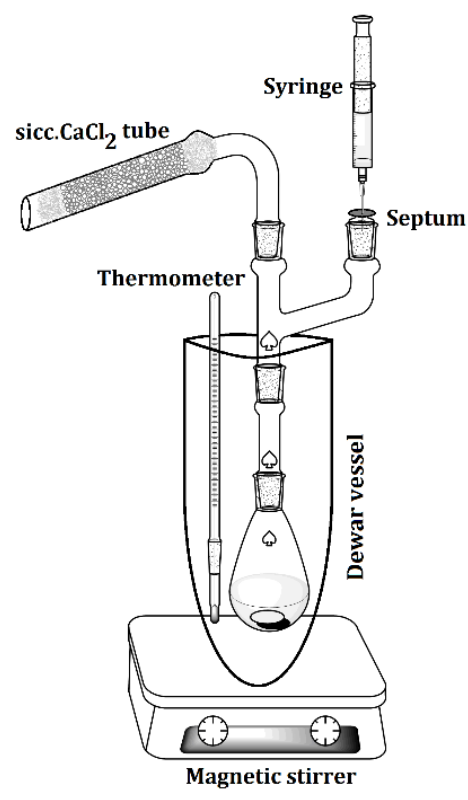

Figure 41 The cryogenic apparatus applied for the $Z$-selective HWE synthesis

\begin{tabular}{|c|c|c|c|c|c|c|}
\hline Entry & Phosphonate & Base & Additive & Conditions & $Z: E$ ratio & Yield \\
\hline 1 & Ando 36 & KHMDS & 18-crown-6 & $-78^{\circ} \mathrm{C} 1 \mathrm{~h}->12 \mathrm{~h}$ r.t. & $96: 4$ & $20 \%$ \\
\hline 2 & Ando 36 & KHMDS & - & $-78^{\circ} \mathrm{C}, 1 \mathrm{~h}$ & $76: 24$ & $75 \%$ \\
\hline 3 & Ando 36 & $t-\mathrm{BuOK}$ & 18-crown-6 & $-78^{\circ} \mathrm{C}, 1 \mathrm{~h}$ & $67: 33$ & $88 \%$ \\
\hline 4 & Ando 36 & $t$-BuOK & - & $-78^{\circ} \mathrm{C}, 1 \mathrm{~h}$ & $90: 10$ & $80 \%$ \\
\hline 5 & Ando 36 & $\mathrm{NaH}$ & 18-crown-6 & $-78^{\circ} \mathrm{C} 5 \mathrm{~min}->0^{\circ} \mathrm{C} 30 \mathrm{~min}$ & $73: 27$ & $9 \%$ \\
\hline 6 & Ando 36 & $\mathrm{NaH}$ & & $-78^{\circ} \mathrm{C} 5 \mathrm{~min}->0^{\circ} \mathrm{C} 30 \mathrm{~min}$ & $66: 34$ & $97 \%$ \\
\hline 7 & S.-G. 33 & KHMDS & 18-crown-6 & $-78^{\circ} \mathrm{C}, 1 \mathrm{~h}->12 \mathrm{~h}$ r.t. & $77: 23$ & $90 \%$ \\
\hline 8 & S.-G. 33 & KHMDS & - & $-78^{\circ} \mathrm{C}, 1 \mathrm{~h}$ & $84: 16$ & $85 \%$ \\
\hline 9 & S.-G. 33 & $t$-BuOK & 18-crown-6 & $-78^{\circ} \mathrm{C}, 1 \mathrm{~h}$ & $76: 24$ & $87 \%$ \\
\hline 10 & S.-G. 33 & $t$-BuOK & - & $-78^{\circ} \mathrm{C}, 1 \mathrm{~h}$ & $68: 32$ & $74 \%$ \\
\hline 11 & S.-G. 33 & $\mathrm{NaH}$ & 18-crown-6 & $-78^{\circ} \mathrm{C} 5 \mathrm{~min}->0^{\circ} \mathrm{C} 30 \mathrm{~min}$ & $34: 66$ & $85 \%$ \\
\hline 12 & S.-G. 33 & $\mathrm{NaH}$ & - & $-78^{\circ} \mathrm{C} 5 \mathrm{~min}->0^{\circ} \mathrm{C} 30 \mathrm{~min}$ & $73: 27$ & $88 \%$ \\
\hline 13 & HWE 29 & KHMDS & 18-crown-6 & $-78^{\circ} \mathrm{C}, 1 \mathrm{~h}$ & $34: 66$ & $91 \%$ \\
\hline 14 & 67 & KHMDS & 18-crown-6 & $-78^{\circ} \mathrm{C}, 1 \mathrm{~h}$ & $35: 65$ & $7 \%$ \\
\hline
\end{tabular}

Table 5 Results of the optimization of the $Z$-selective HWE synthesis 
The Ando reagent 36, shows the best results, when $t$-BuOK 72 applied as a base without any additives (Entry: 4 on Table 5); therefore, this variant was chosen for the synthesis of the Z-heteroaryl cinnamic acid methyl esters.

The successful reaction mixtures, worked up with flash column chromatography on Normasil 60 silica gel, were eluted with $\mathrm{MeOH}-\mathrm{CHCl}_{3}, 5: 95$. The purified methyl esters were hydrolyzed in THF/4 eq. KOH solution at r.t. for $12 \mathrm{~h}$. The resulting mixture was neutralized with cc. $\mathrm{HCl}$. The precipitated crystals were filtered, washed with water and then dried. The pyridyl derivatives form hydrochloride salts so they should be titrated with piperidine $\mathbf{2 0}$ to get the precipitated crystals. The applied reaction conditions and the chromatography parameters for the Z-methyl heteroaryl cinnamates are shown in Table 6.

\begin{tabular}{|c|c|c|c|c|}
\hline$Z: E$ ratio & $\begin{array}{l}\text { Yield } \\
\text { (GC): }\end{array}$ & $\begin{array}{l}\text { Structure of the Me-ester } \\
\text { products }\end{array}$ & $\begin{array}{c}\mathbf{R}_{\mathrm{f}} \text { of the } \\
\text { Me-esters }\end{array}$ & $\begin{array}{l}\text { Structure of the final } \\
\text { products }\end{array}$ \\
\hline $87: 13$ & $87 \%$ & Me $\left.\right|_{\text {COOMe }}$ & 0.78 & $\underbrace{Y_{0} \mathrm{Z32F}}_{0}\rceil_{\mathrm{COOH}}$ \\
\hline $97: 3$ & $94 \%$ & & 0.83 & OOH \\
\hline 89:11 & $70 \%$ & COOMe & 0.75 & $\mathrm{COOH}$ \\
\hline $87: 13$ & $75 \%$ & & 0.76 & $33 \mathrm{~T}$ \\
\hline $84: 16$ & $97 \%$ & & 0.29 & Z32P \\
\hline 89:11 & $90 \%$ & & 0.32 & $33 \mathrm{P}$ \\
\hline $93: 7$ & $86 \%$ & $\mathrm{PMe}$ & 0.31 & Z34P \\
\hline $90: 10$ & $60 \%$ & & 0.82 & 73. \\
\hline
\end{tabular}

Table 6 The results of the Z-selective synthesis of heteroaryl cinnamyl esters with Ando reagent (36)

The structures of the Z-methyl heteroaryl cinnamates were determined by ${ }^{1} \mathrm{H}$ NMR spectroscopy, and it was found that each derivative was successfully synthesized, both in the methyl ester and the acidic forms. 
The ${ }^{1} \mathrm{H}$ NMR spectra of the Z-methyl heteroaryl cinnamates and the acids - they are not available in the literature - were the following:

The ${ }^{1} \mathrm{H}$ NMR spectra of the Z-methyl heteroaryl cinnamates:

Z33F-Me: ${ }^{1} \mathrm{H}$ NMR $\left(500 \mathrm{MHz}, \mathrm{CDCl}_{3}\right) \delta=3.76(\mathrm{~s}, 3 \mathrm{H}), 5.78-5.81(\mathrm{~d}, \mathrm{~J}=12.5 \mathrm{~Hz}, 1 \mathrm{H})$, 6.69-6.71 (d, J = 12.5 Hz, 1H), $6.92(\mathrm{~s}, 1 \mathrm{H}), 7.39$ (s, 1H), $8.11(\mathrm{~s}, 1 \mathrm{H})$.

Z34P-Me: ${ }^{1} \mathrm{H}$ NMR (500 MHz, $\left.\mathrm{CDCl}_{3}\right) \delta=3.69(\mathrm{~s}, 3 \mathrm{H}), 6.11-6.13(\mathrm{~d}, \mathrm{~J}=12.5 \mathrm{~Hz}, 1 \mathrm{H})$, 6.86-6.89 (d, J = 12.5 Hz, 1H), 7.36 (br, 2H), 8.59 (br, 2H).

Z32S-Me: ${ }^{1} \mathrm{H}$ NMR $\left(500 \mathrm{MHz}, \mathrm{CDCl}_{3}\right) \delta=3.78(\mathrm{~s}, 3 \mathrm{H}), 5.74-5.76(\mathrm{~d}, \mathrm{~J}=12.2 \mathrm{~Hz}, 1 \mathrm{H})$, 6.96-6.99 (d, J = 12.4 Hz, 1H), 7.26-7.28 (d, J = 12.5 Hz, 1H), 7.42 (br, 1H), 7.54 (br, 1H), $8.31(\mathrm{br}, 1 \mathrm{H})$.

The ${ }^{1} \mathrm{H}$ NMR spectral data of the Z-heteroaryl cinnamic acids:

Z33F: ${ }^{1}$ H NMR (500 MHz, DMSO-d6) $\delta=5.74-5.77$ (d, J = 12.5 Hz. 1H), 6.77-6.79 (d, 12.5 $\mathrm{Hz}, 1 \mathrm{H}), 7.02$ (br, 1H), $7.67(\mathrm{br}, 1 \mathrm{H}), 8.22(\mathrm{~s}, 1 \mathrm{H})$.

Z34P: ${ }^{1}$ H NMR (500 MHz, MeOD-d4) $\delta=6.15-6.17(\mathrm{~d}, \mathrm{~J}=12.2 \mathrm{~Hz}, 1 \mathrm{H}), 6.58-6.61(\mathrm{~d}, \mathrm{~J}=$ $12.3 \mathrm{~Hz}, 1 \mathrm{H}), 7.42(\mathrm{~s}, 2 \mathrm{H}), 8.55(\mathrm{~s}, 2 \mathrm{H})$.

Z32S: ${ }^{1} \mathrm{H}$ NMR (500 MHz, DMSO-d6) $\delta=5.68-5.70(\mathrm{~d}, \mathrm{~J}=12.2 \mathrm{~Hz}, 1 \mathrm{H}), 7.28-7.30(\mathrm{~d}, \mathrm{~J}=$ $11.8 \mathrm{~Hz}, 1 \mathrm{H}$ ), 7.37-7.38 (d, J = 3.9 Hz, 1H), 7.59-7.60 (d, J = 3.3 Hz, 1H), 8.24-8.25 (d, J= $5.4 \mathrm{~Hz}, 1 \mathrm{H})$.

\subsection{Synthesis of the $\alpha$-substituted cinnamic acid derivatives}

Due to the synthetic work of the former members of our research group, several $\alpha$ substituted cinnamic acids were prepared via the modified Perkin condensation. Thus, many thienyl-substituted variants were available at the beginning of my work. They have already been shown in Figure 24 (each possible variations and isomers with one or two thienyl rings). The furyl derivatives were widely studied materials, therefore, this part of the compound family was skipped, and we tried to synthesize the pyridyl derivatives. As it has been mentioned before, the synthesis of substituted selenophenyl compounds were not done (only the E-Z-3-(2-selenophenyl)propenoic acids were synthesized), due to safety considerations. The modified Perkin condensation between the proper heteroaryl carboxaldehyde and the heteroaryl acetic acid in acetic anhydride $\mathbf{8}$ in the presence of 
TEA, as it described in the literature part, was applied for the synthesis of the pyridyl derivatives, the modified Döbner condensation and the HWE olefination method were also tried, and this latter was found to be the best synthetic route to $\alpha$-substituted pyridylcinnamic acids. The general procedures applied for the synthesis are listed in the followings.

4.6.1 The synthesis of E-Z-3-phenyl-2-(3-pyridyl)propenoic acid via the modified Perkin condensation<smiles>O=Cc1ccccc1</smiles><smiles>CCCCCCCCCCC(=O)O</smiles>

73<smiles>O=C(O)/C(=C/c1ccccc1)c1cccnc1</smiles>

Z23P3Ph

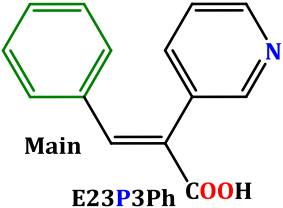

E23P3Ph $\mathrm{COOH}$

Figure 42 The synthesis of Z3Ph23P with the modified Perkin condensation

1.1 eq. of 3-pyridylacetic acid 73 and 1 eq. of 7 were dissolved in the mixture of TEA and $\mathrm{Ac}_{2} \mathrm{O}, 2: 1$. The mixture was brought to $100^{\circ} \mathrm{C}$ on a water bath and was kept at this temperature for $1 \mathrm{~h}$. The dark reaction mixture was evaporated, and the residue was treated with cc. $\mathrm{HCl}$; then, the unreacted aldehyde was removed with extraction (diethyl ether). The acidic mixture was titrated with piperidine 20 at $0^{\circ} \mathrm{C}$ until the product started to precipitate. The precipitate was a mixture of pyridyl compounds to be further processed via column chromatography on Normasil 60 eluted with DMSO. Yield: 5\% of the theoretical, isomer distribution: 72:28; E:Z $\left({ }^{1} \mathrm{H} \mathrm{NMR}^{*}\right)$.

Unfortunately, this method provided with low yield, and the separation of the resulting materials were difficult (because the title material only soluble in DMSO which is a too powerful eluent); nevertheless, both isomers could be synthesized via the reaction. The preparation of these compounds was tried with the Döbner method, but the reaction did not take place (yield: $<1 \%$ ). 
4.6.2 The synthesis of E-2-phenyl-3-(3-pyridyl)propenoic acid via the HWE method

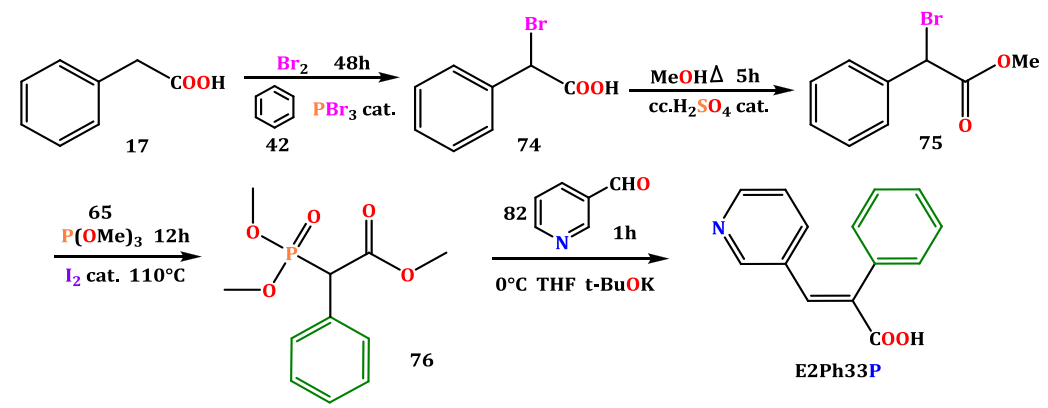

Figure 43 Preparation of trimethyl phosphono-2-phenylacetate and the condensation of it with 3 pyridinecarboxaldehyde

Preparation of 2-bromophenylacetic acid 74: 1 eq. of phenylacetic acid 17 was dissolved in benzene 42 and 1.1 eq. of bromine was added. Catalytic amount of $\mathrm{PBr}_{3}$ was added as well, and the mixture was gently refluxed for $48 \mathrm{~h}$. The benzene was removed via distillation; then, the residue was dissolved in petroleum ether and was stored at $-20^{\circ} \mathrm{C}$ for $12 \mathrm{~h}$. The precipitated crystals 74 were filtered off and dried. ${ }^{146}$ Yield: $65 \%$ white crystalline product $\left(97 \%{ }^{1} \mathrm{H} \mathrm{NMR}^{*}\right)$.

Preparation of methyl 2-bromo-2-phenylacetate 75: 1 eq. of 74 dissolved in 15 eq. of anhydrous methanol and catalytic amount of $\mathrm{cc}$. $\mathrm{H}_{2} \mathrm{SO}_{4}$ was added. The mixture was refluxed for $5 \mathrm{~h}$, and the excess methanol was removed under reduced pressure. The residue was washed with saturated $\mathrm{Na}_{2} \mathrm{CO}_{3}$ solution, and was extracted with diethyl ether. The ether was removed, and the residue was distilled at $100 \mathrm{mbar}$ and the fraction between $160-165^{\circ} \mathrm{C}$ was collected as colorless oil 75. Yield: $68 \%$ of the theoretical $(98 \%, \mathrm{GC})$.

Preparation of trimethyl 2-phenyl phosphonoacetate 76 (Michaelis-Arbuzov): 1 eq. of 75 was dissolved in 4 eq. of trimethyl phosphite 65, and a small crystal of iodine was added. The mixture was refluxed for $12 \mathrm{~h}$; then, the volatiles were removed under reduced pressure. The residue was a dark brown oily compound $\mathbf{7 6}, 67 \%$ of the theoretical $(95 \%, \mathrm{GC})$.

Preparation of E-2-phenyl-3-(3-pyridyl)propenoic acid: 1 eq. of $t$-BuOK was dissolved in THF, and was cooled to $0^{\circ} \mathrm{C}$ for 15 min. 1 eq. of 76 was added (as a THF solution), and the residue was stirred for an additional $15 \mathrm{~min}$. 1 eq. of 3pyridinecarboxaldehyde 82 was injected, and the solution stirred for $1 \mathrm{~h}$ at $0^{\circ} \mathrm{C}$. The 
reaction was quenched with $\mathrm{NH}_{4} \mathrm{Cl}$ solution; then, extracted with EtOAc. The solvent was removed, and the resulting methyl ester ( $65 \%$ of the theoretical) was stirred with 4 eq. $\mathrm{KOH}$ in THF for $12 \mathrm{~h}$ at r.t. The THF was evaporated, and then the residue treated with cc. $\mathrm{HCl}$ until it's became strongly acidic. The mixture cooled to r.t. and titrated with piperidine 20 until the formation of the precipitate stopped. The precipitated crystals were filtered off, washed with water and dried. Yield: 100\% quant. in two steps (99\% ${ }^{1} \mathrm{H}$ NMR, $100 \%$ E). E2Ph33P-Na: ${ }^{1} \mathrm{H}$ NMR (500 MHz, $\left.\mathrm{D}_{2} \mathrm{O}\right) \delta=6.68-6.70\left(\mathrm{dd}, \mathrm{J}_{\mathrm{A}}=3.8 \mathrm{~Hz}\right.$, $\left.\mathrm{J}_{\mathrm{B}}=7.6 \mathrm{~Hz}, 1 \mathrm{H}\right), 6.77-6.78(\mathrm{~m}, 2 \mathrm{H}), 6.86-6.87(\mathrm{~d}, \mathrm{~J}=7.9 \mathrm{~Hz}, 1 \mathrm{H}), 7.03-7.04(\mathrm{~m}, 3 \mathrm{H}), 7.08(\mathrm{~s}$, $1 \mathrm{H}), 7.82(\mathrm{~s}, 1 \mathrm{H}), 7.86-7.87(\mathrm{~d}, \mathrm{~J}=3.5 \mathrm{~Hz}, 1 \mathrm{H})$.

\subsection{Computational chemistry part: software and methods}

\subsubsection{Official software packages}

- Each molecular model structure was created with Arguslab 4.02147, which is a bit outdated, shareware, but it is a still reliable quantum chemical tool for building molecular structures fast and easy.

- $\quad$ The preoptimization of the drawn molecules was performed with the Hyperchem 8.0.6 Pro. ${ }^{148}$ package at low level of theory (PM3 ${ }^{149}$, HF$^{150} /$ STO-3G $\left.{ }^{151}\right)$. The software package is very user friendly; however, its performance is poor (the academic version is available only for $1 \mathrm{CPU}$ core), and there are some problems with the reproducibility of the results generated.

- To use high-level methods and to calculate structures and energies precisely for larger systems as well, the Gaussian 09' rev. D.01 ${ }^{152}$ was used. The version is not locked to 1 CPU core; therefore, it performs much better with the relevant hardware and provides with reproducible data.

- To extract useful data from the Gaussian output files, the Avogadro v1.1.1153 program was applied, which is a free cross-platform molecular editor and visualizer.

\subsubsection{Creating software for conformational analysis (Quantum Hyppo and Izzy Reader)}

Hyperchem 8.0.6 has an automatic conformational analysis module; however, the performance of the program is low, as it was mentioned before, and the energy limit defining stable conformers should be set at the beginning of the calculation, which leads to many unstable conformers. Gaussian 09' does not have an automatic tool to perform 
conformational analysis; however, its input, output and batch file structures are welldefined, thus, the generation of files and getting out data in very high numbers are possible with some simple scripts, therefore it was decided to write a conformational analysis tool, which can be used with Gaussian 09' to setup and perform complex conformational search with a few mouse clicks. The main advantage of this method is its versatility. One does not have to define the terms before the calculations; they always can be modified in the knowledge of the initial results.

The choice was AutoHotkey v1.1 153 (AHK, 1.1.16.05, 2014), which is a scripting and automation software for Windows operating systems using a simple language-based on AutoIt. The programs written are called Quantum Hyppo v.1.0 (demo version), and Izzy Reader v1.0 (demo version as well), they are available as downloads from http://www.staff.u-szeged.hu/ csankok/7542/QH_win32.zip free of charge. The current demo versions work properly under: Vista, Win7 and Win8(.1). The programs use the following algorithms:

1. Finding the line(s) in the Gaussian input file, containing the atomic numbers, which define the dihedral angles. These lines can be found after the $4^{\text {th }}$ empty line (the following example shows the representative file structure of Gaussian 03-09 .gjf files):

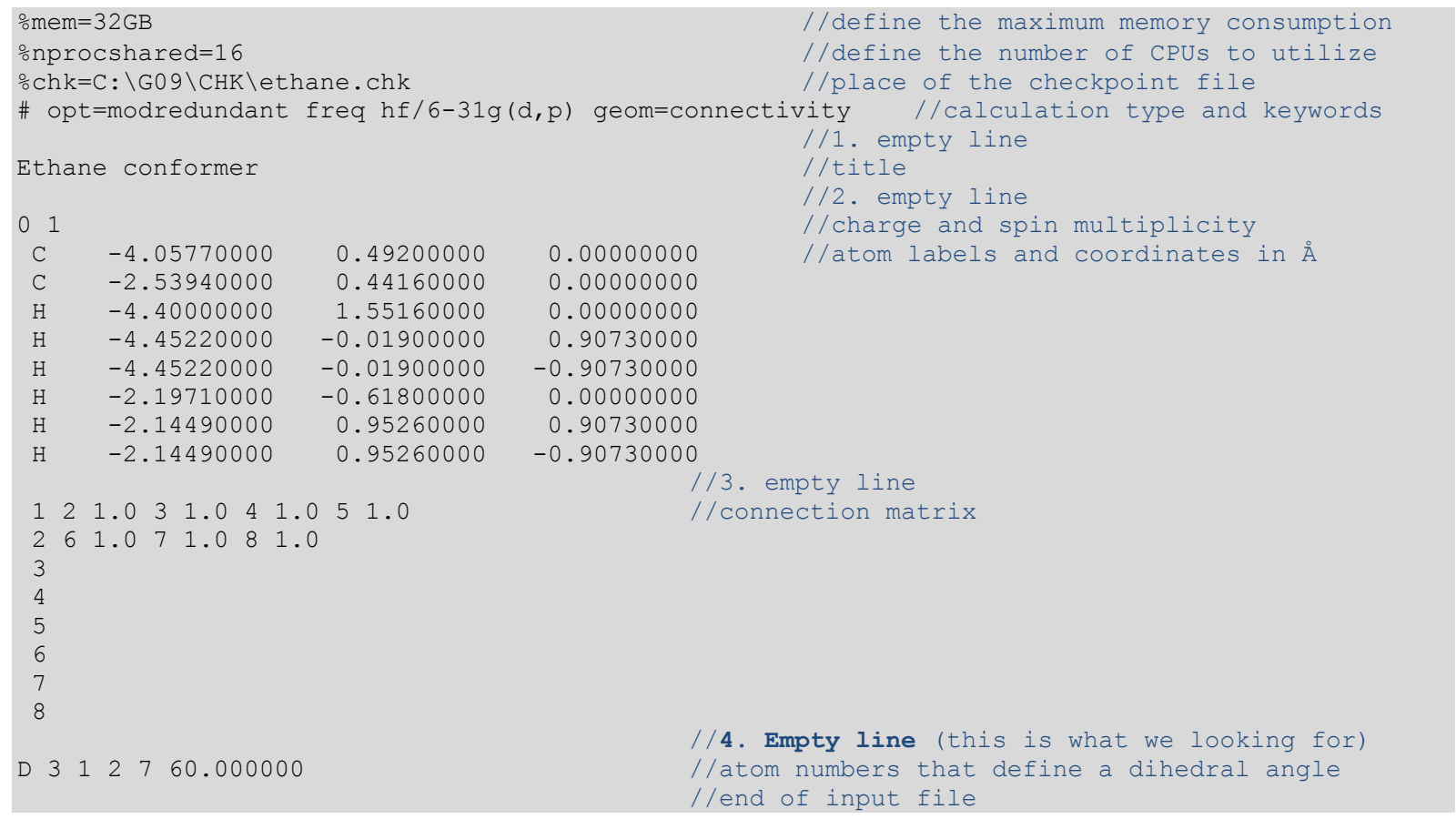

2. The lines, containing the dihedral data set are counted; then, the dihedral angles, which are floating point values, are changed randomly between the defined angle range 
(default: $\min =-180.0$ to $\max =180.0$ ). The new file saved uses the following name format: 00001yourfilename.gjf and the number will be increased by 1 in each cycle. The number of the iteration can be defined as well (vari=). After creating the files, the batch file will be created as well (the file routes for inputs and outputs can be defined freely). The graphical user interface of the program is shown in Figure 44.

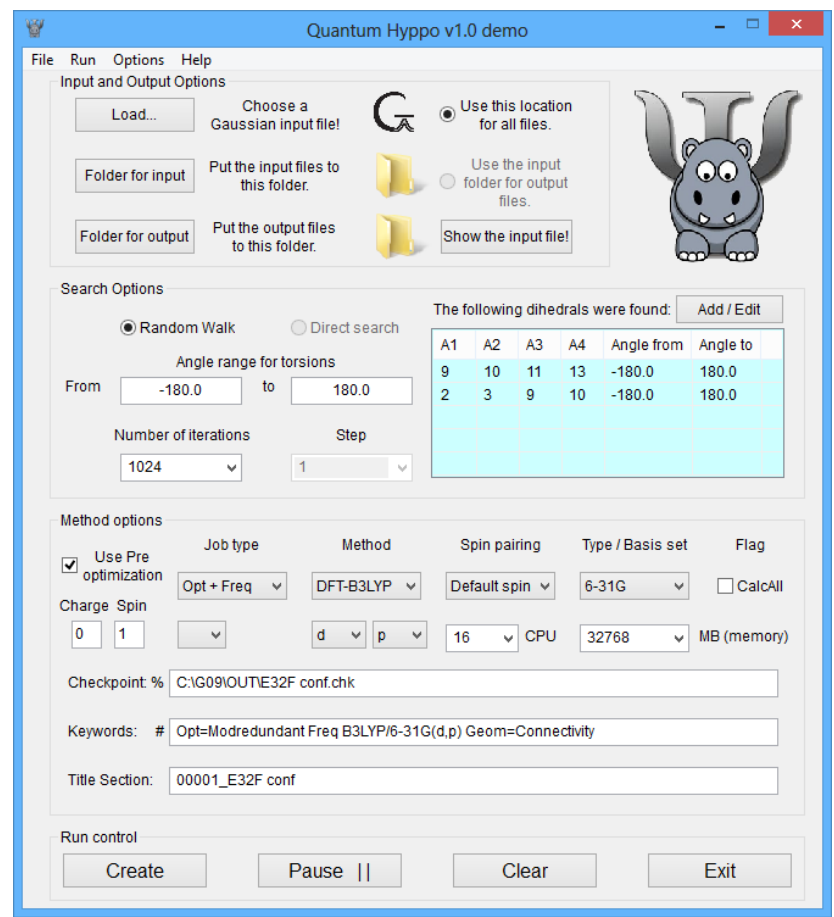

Figure 44 The graphical user interface (GUI) of Quantum Hyppo v.1.0 demo (under Win8)

3. The main features of the program are as follows: it works with any pregenerated Gaussian job file (.gjf); it reads out many data from the file, thus, one can change them easily, including the manipulation with the dihedral angles, the keywords, the specifications and file routes; the created batch file can be executed automatically if one has valid Gaussian 03' or 09' installed on your computer. The simplified source code of Quantum Hyppo v1.0 demo can be found in the Appendix.

4. After getting the output files from the Gaussian package, one needs to process these files to get out the useful data like energies, lowest vibrational frequencies, dihedral angles and optimized geometries if they needed. The output files generated by the package are long and complex (4000-12000 lines), thus, no example is presented here, only the relevant parts of the file are extracted like the zero-point energy, the lowest vibrational frequency, the dihedral section and the optimized geometry (the following example shows the representative file structure of Gaussian 03-09' .out and .log files): 


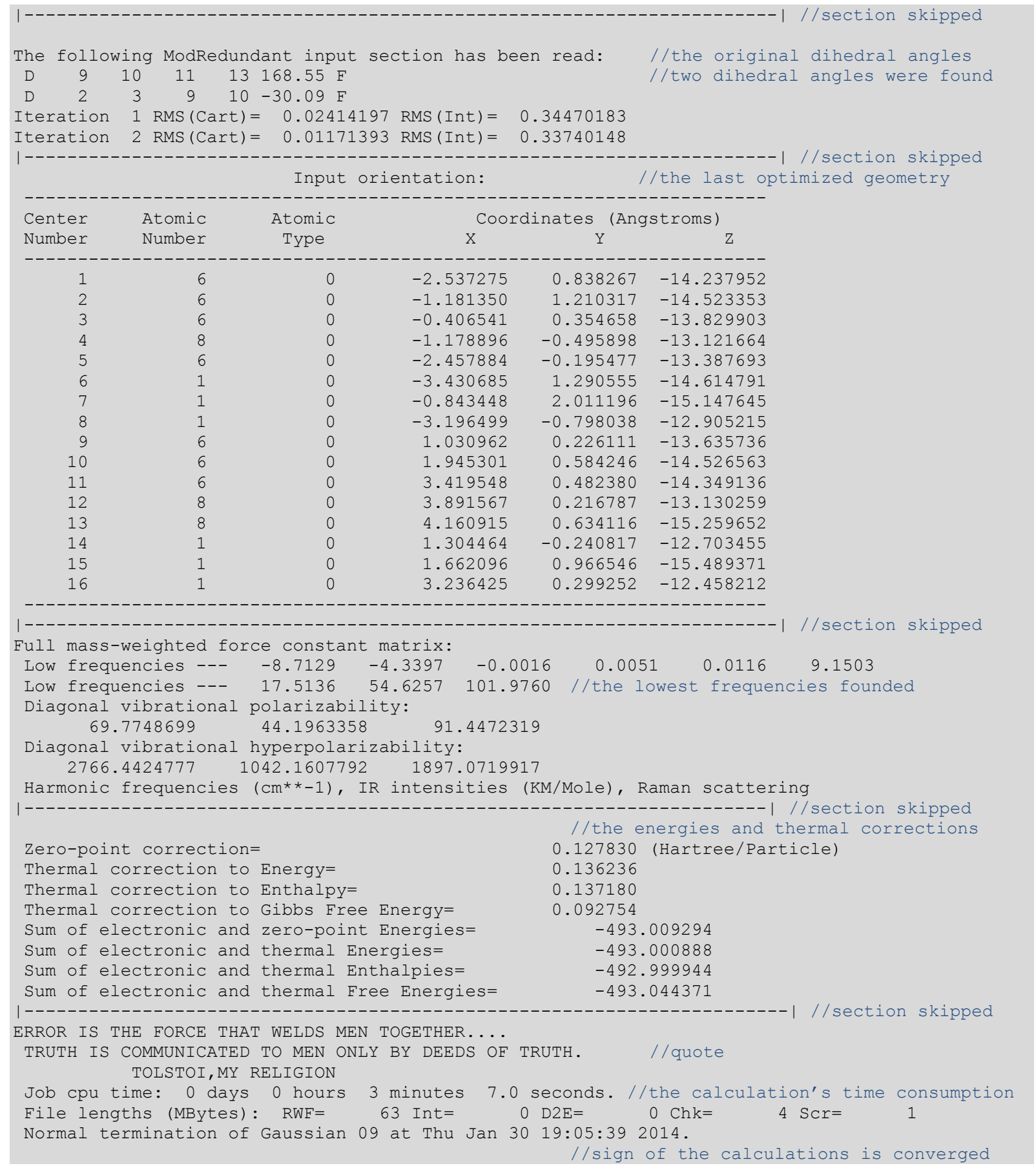


5. The GUI of the data extracting software is shown in Figure 45.

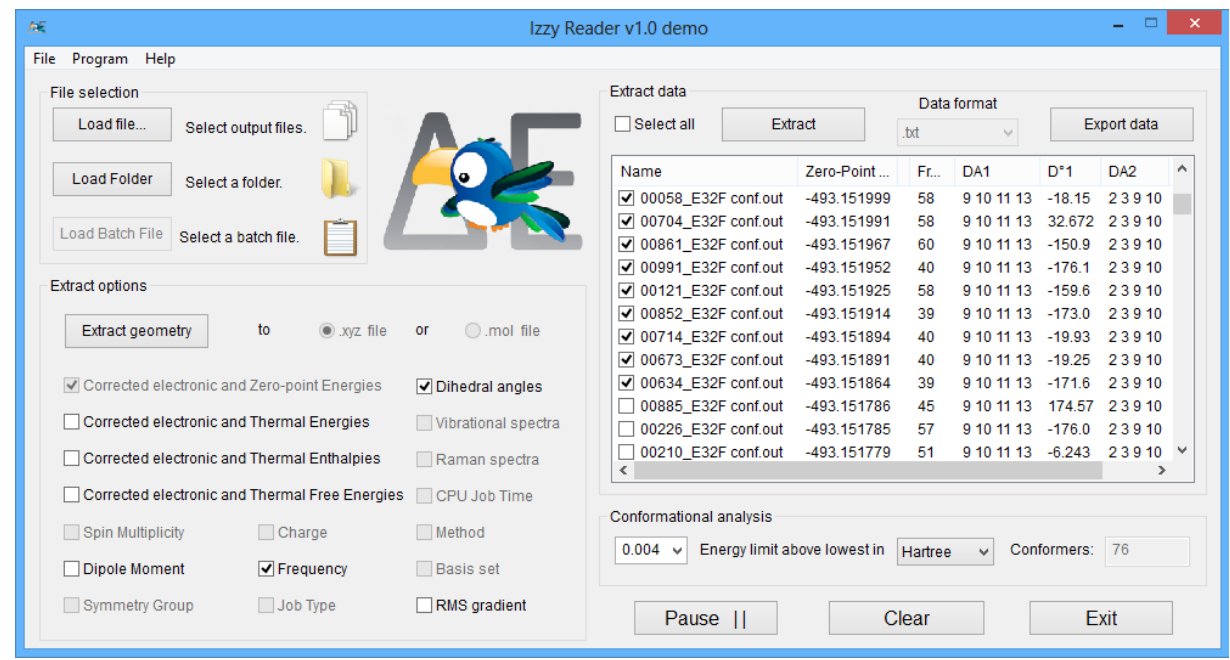

Figure 45 The graphical user interface of Izzy Reader v.1.0 demo (under Win8)

The main features of the program are as follows: the different energies, the dipole moment, the lowest frequency, the dihedral sets and the RMS gradient can be extracted; the list made in a list view can be cut short freely, and can be filtered by the energy to find the conformers; these can be checked by one click and can exported to tabseparated ASCII file; the geometries from the selected files can be extracted as well in .xyz (that giving the geometry by Cartesian coordinates and atom symbols in a simple text file).

The simplified source code of Izzy Reader v.1.0 can be found in the Appendix.

\subsubsection{The applied quantum chemical methods}

As it has been mentioned before, the molecular model of the studied molecules are drawn in Arguslab 4.02 and are stored in MDL .mol files; then, the structures were preoptimized at the PM3 level (or at HF/STO-3G if it was necessary) using Hyperchem 8.0.6. The optimized individual monomers (M) were translated to Gaussian 09' input format, and the two possible dihedral angle sets (determined by the serial number of the $4-4$ atoms sets) were determined.

\section{- Conformational analysis of the monomers (M)}

The input files were used to generate 1024 variations for the molecules, which have two variable dihedrals (cinnamic acids) and 2048 variations for the $\alpha$-substituted cinnamic acids, due to the three possible rotations, from $-180^{\circ}$ to $180^{\circ}$, applying the 
"random walk" method with Quantum Hyppo v.1.0. The generated geometries were preoptimized at the PM6 ${ }^{154}$ level with Gaussian 09' to find faulty geometries. These were removed from the batch file, then, the rest were optimized at the HF/631G(d,p) ${ }^{155}$ level, and the results were processed to determine the lowest point of the potential energy surface. It belongs to the most stable conformer, which was used as a starting point in further calculations.

- The geometries and the energies of the monomers (M)

From each conformational search, the lowest-energy monomer was selected, and it was further optimized at several different levels like B3LYP156/6-31G(d,p), B3LYP/631++G(d,p) ${ }^{157}$, B3LYP/CBSB7 ${ }^{158}$, (MP2 $\left.{ }^{159} / 6-31 G(d, p)\right), W B 97 X D^{160} / 6-31++G(d, p)$ and WB97XD/CBSB7 to make references for the hydrogen-bond and $\pi$-stacking energy calculations (CBSB7 uses the 6-311G(2d,d,p) basis set with three polarization functions, and it adapts the functions only when needed, e.g. the $\mathbf{2 d}$ function for $\mathrm{S}$ and $\mathrm{Se}$ atoms).

\section{- Geometry and the H-bond energy of the dimers (D)}

From the refined monomers, dimers (D) were built having the carboxylic groups close to each other. The dimers were optimized using the above-listed methods (including the HF/6-31G(d,p) method and the B3LYP/CBSB7 method). To determine the correct $\mathrm{H}$ bond energy, the calculations were performed using the Counterpoise method, (CP) ${ }^{161}$, which corrects the energy influence coming from the so-called Basis Set Superposition Error (BSSE). ${ }^{162}$

- Geometry and the H-bond energy of the tetramers (T)

The tetramers are the dimers of the dimers, kept together via weaker second order hydrogen-bonds by the heteroaromatic rings, via the polarized aromatic protons and the heteroatoms: $\mathrm{C}-\mathrm{H} \ldots \mathrm{X}(\mathrm{X}=\mathrm{O}, \mathrm{N}, \mathrm{S}, \mathrm{Se})$. The calculations were performed the same levels as for the dimers, and the necessary corrections for the energy calculations have also been made. Due to the higher complexity of the $\alpha$-susbtituted cinnamic acids the calculations for their tetramers are skipped.

- Geometries and bond energies for the various $\pi$-stacked dimers

The stacked dimers were constructed from the optimized monomers making the "sandwich" form, since this the most favored geometry. The calculations were performed by the WB97XD/6-31++G(d,p) and WB97XD/CBSB7 methods. The WB97XD is a DFT method, which is recommended for modelling $\pi$-stacking interactions ${ }^{160}$. 
- The calculation types performed are listed in 5.6, where the red cross means the calculations did not converged; therefore, only single-point energy calculation was performed for the molecule with fixed geometric parameters. For the thienyl-derivatives, our choice was $300 \mathrm{pm}$ bond length for the secondary H-bond, and $350 \mathrm{pm}$ for the selenophenyl derivatives. These bond lengths are based on lower level calculations and the Bondi criteria. ${ }^{163}$ 


\section{RESULTS AND DISCUSSION}

\subsection{Summary of the synthetic part}

\subsubsection{The results of the E-selective methods}

Several different condensation reactions were tried to find the best method having the highest yield and stereoselectivity for the synthesis of heteroaromatic cinnamic acid derivatives. The results of the whole synthetic part are summarized in Table 7. As one can observe, the yield and the selectivity of the listed methods leading to E-cinnamic acid show very little difference; nevertheless, these techniques differ from each other in the nature of the products, the difficulty of the reaction and the number of the reaction steps. The Knövenagel-Döbner condensation was chosen for the synthesis of $E$ heterocyclic cinnamic acids, because this reaction provides the best yield and reproducibility in a one-pot synthesis, and the purity of the resulting cinnamic acids was fair enough without recrystallization (>95\%), and after a single purification step, it increased to $99-99.5 \%$. The disadvantages lie in the solvent and the catalyst, because pyridine $\mathbf{4 3}$ and piperidine $\mathbf{2 0}$ are noxious materials. The Knövenagel-Döbner method has very good scalability as well. The yields did not drop below 95\% on increasing the starting amount of benzaldehyde from $50 \mu \mathrm{l}$ to $50 \mathrm{ml}$. Therefore, this method was applied for the synthesis of all the targeted materials, and, as it was indicated in the experimental section (4.3.7), the yield and the selectivity were very good in all cases. Consequently, it can be stated that the Knövenagel-Döbner method is the best choice for the synthesis of E-cinnamic acids and E-3-heteroaryl propenoic acid derivatives. It is especially true for the pyridylcinnamic acids, because they are hardly accessible via other condensation methods. 


\begin{tabular}{|c|c|c|c|c|c|c|c|}
\hline $\begin{array}{l}\text { Condensation } \\
\text { Method }\end{array}$ & $\begin{array}{l}\text { Reaction } \\
\text { time }\end{array}$ & Product & Yield & $\begin{array}{c}Z: E \\
\text { ratio }\end{array}$ & $\begin{array}{l}\text { Additional } \\
\text { steps to title } \\
\text { product }\end{array}$ & Advantages & Disadvantages \\
\hline Perkin & $2 \mathrm{~h}$ & & $81-92 \%$ & $0: 100$ & 2 & $\begin{array}{l}\text { Simple setup, non-toxic } \\
\text { reagents, acceptable yield. }\end{array}$ & Side reactions with some heterocyclic aldehydes. \\
\hline Claisen-Schmidt & $4 \mathrm{~h}$ & & $60-65 \%$ & $0: 100$ & 2 & $\begin{array}{l}\text { Cheap reagents, leads to } \\
\text { esters in one step. }\end{array}$ & $\begin{array}{l}\text { Handling molten sodium, high solvent volume } \\
\text { needed, low yield. }\end{array}$ \\
\hline Knövenagel & $14 \mathrm{~h}$ & & $85-87 \%$ & $0: 100$ & 3 & $\begin{array}{l}\text { The first step leads to } \\
\text { malonic acid derivatives. }\end{array}$ & $\begin{array}{l}\text { Complicated setup, long reaction time, } 3 \\
\text { additional steps needed. }\end{array}$ \\
\hline Knövenagel-Döbner & $3 \mathrm{~h}$ & & $95-99 \%$ & $0: 100$ & 1 & $\begin{array}{l}\text { Simple setup, excellent } \\
\text { yield in one step, high } \\
\text { purity, cheap reagents. }\end{array}$ & Noxious solvent and catalyst. \\
\hline Perkin-Döbner (MW) & $30 \mathrm{~min}$ & & $60-87 \%$ & $0: 100$ & 2 & $\begin{array}{l}\text { Very short reaction time, } \\
\text { simple conditions. }\end{array}$ & $\begin{array}{l}\text { Expensive reagents and safe microwave reactor } \\
\text { needed. }\end{array}$ \\
\hline UV-isomerization & $16 \mathrm{~h}$ & & $100 \%$ & $62: 38$ & 0 & $\begin{array}{l}\text { Simple conditions, } \\
\text { acceptable yield for the } Z \text { - } \\
\text { isomer. }\end{array}$ & The separation of the isomer mixture is difficult. \\
\hline $\begin{array}{l}\text { Lindlar } Z \text {-selective } \\
\text { hydrogenation }\end{array}$ & $2 \mathrm{~h}$ & & $85-95 \%$ & $95: 5$ & 4 & High yield and selectivity. & $\begin{array}{l}\text { Sensitive for conditions, needs an alkyne } \\
\text { derivative as a substrate. }\end{array}$ \\
\hline $\begin{array}{l}Z \text {-selective HWE: } \\
\text { Still-Gennari }\end{array}$ & $3 \mathrm{~h}$ & & $85-95 \%$ & $84: 16$ & 9 & $\begin{array}{l}\text { High yield and } Z \text { - } \\
\quad \text { selectivity. }\end{array}$ & $\begin{array}{l}\text { Cryogenic conditions needed, the reagent is } \\
\text { expensive. }\end{array}$ \\
\hline $\begin{array}{l}\text { Z-selective HWE: } \\
\text { Ando }\end{array}$ & $3 \mathrm{~h}$ & & $80-97 \%$ & $90: 10$ & 9 & $\begin{array}{l}\text { High yield and } Z \text { - } \\
\text { selectivity. }\end{array}$ & $\begin{array}{l}\text { Cryogenic conditions needed, the reagent is hardly } \\
\text { accessible. }\end{array}$ \\
\hline $\begin{array}{l}\text { Modified Perkin } \\
\text { condensation }\end{array}$ & $1 \mathrm{~h}$ & & $5 \%$ & $78: 22$ & 5 & $\begin{array}{l}\text { Simple reaction } \\
\text { conditions. }\end{array}$ & Low yield, the separation is complicated. \\
\hline $\begin{array}{l}\text { HWE: with aromatic } \\
\text { phosphonates }\end{array}$ & $2 \mathrm{~h}$ & & $78 \%$ & $0: 100$ & 7 & High yield and selectivity. & The reagent is hardly accessible. \\
\hline
\end{tabular}

Table 7 Summary of the tested reactions for the synthesis of $E$ and Z-cinnamic acids 


\subsubsection{Photoisomerization of E-cinnamic acids}

The UV-induced isomerization technique is a promising procedure to synthesize Z-cinnamic acids. It can be carried out with simple equipment (4.2.3) and provides high amount of $Z$ isomer within acceptable time scale (12 h for $\mathbf{1 / E})$. It leads to equilibrium, and can be described as a pseudo first order reaction (Figure 46). The equilibrium constant is $\mathrm{K}=1.63 \pm 0.01$ and the rate coefficients are: $\mathrm{kf}_{\mathrm{f}}=2.37 \times 10^{-5} \pm 9.5 \times 10^{-7} \mathrm{~s}^{-1}, \mathrm{~kb}=$ $1.46 \times 10^{-5} \mathrm{~s}^{-1} \pm 1.46 \times 10^{-7} \mathrm{~s}^{-1}$ for $\mathbf{1} / \mathbf{E}$.

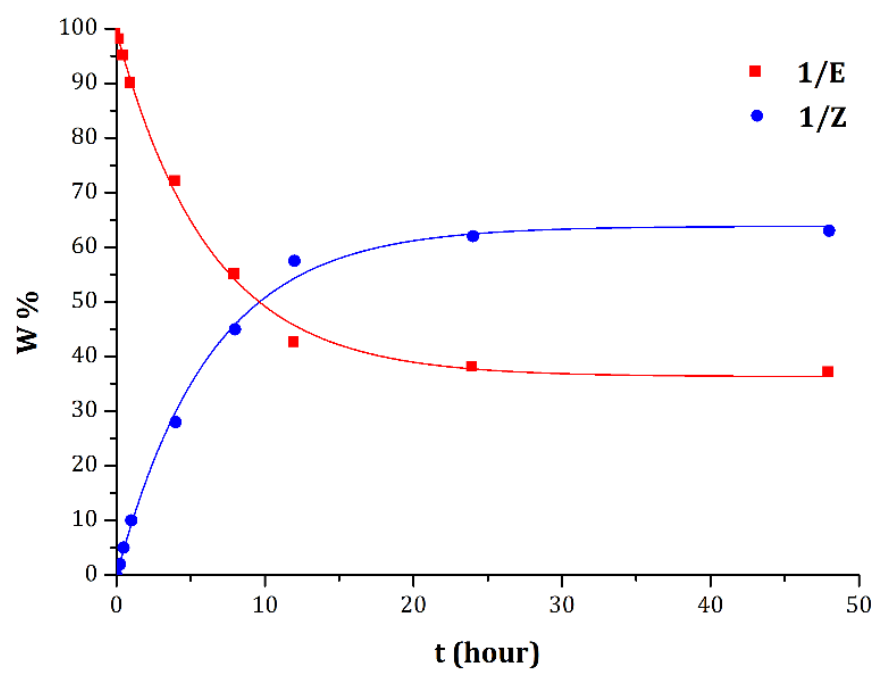

Figure 46 Determining the equlibrium and the rate constants for the isomerization of $\mathbf{1 / E}$ from the kinetic curve

As it was seen in the experimental part (4.4.1), the distribution of the isomers in the equilibrium, varies from 29 to $87 \%$ (determined by ${ }^{1} \mathrm{H}$ NMR after $24 \mathrm{~h}$ irradiation) for the heteroaryl propenoic acids; only the E33P, E34P and E2Ph33P derivatives show low isomerization activity because of the low solubility of the compounds in EtOAc. These materials are only soluble in dipolar aprotic solvents like DMSO, which has an absorption band around $254 \mathrm{~nm}$; therefore, the procedure cannot be carried out in DMSO.

The semi discontinuous UV-reactor is applied for the accumulation of E-Z32F, EZ32T and E-Z32P isomer mixtures with the method described in (4.2.3). Several different separation methods were performed on the isomer mixtures to isolate the pure $Z$ isomers from the more easily accessible $E$ isomer.

One can think about many different techniques to separate the stereoisomers like gradual acidification using the different $\mathrm{pKa}$ values of the isomers, or the sublimation 
method utilizing the bp. difference among the isomers. The former method did not work with the heteroarlycinnamic acid isomer mixtures, while the more promising latter one would have needed special equipment. Simple flash column chromatography failed to separate the isomers as well, even the $50 \mathrm{~m}$ long capillary GC column could barely separate the E-Z-methyl ester derivatives - there was some overlap among the peaks -, nevertheless, the two isomers could be clearly identified, and the determined isomer ratio was the same as was found by ${ }^{1} \mathrm{H}$ NMR spectroscopy (with $\pm 1 \%$ deviation).

To sum up, the isomerization method, combined with isomer separation via sublimation/distillation, can be a relevant method to yield Z-cinnamic acid derivatives.

\subsubsection{Summary of the Z-selective methods}

The various $Z$-selective hydrogenation methods showed excellent yields (85-95\%) and Z-selectivities (90-96\%); however, the reaction used to synthesize the starting materials, like 3-phenylpropiolic acid 26, works only for the phenyl derivatives of cinnamic acid. The furyl-, thienyl-, and selenienyl derivatives yield perbrominated molecules after bromination, even if the reaction was carried out at low temperature. The pyridyl-derivatives are insoluble in most of the solvents applied for halogenation, thus, bromination does not take place. The Heck-Mizoroki coupling may be an alternative to synthesize the starting alkynes; unfortunately, the reagents are very expensive for this reaction.

The best method to produce Z-3-heteroaryl propenoic acids was the Z-selective HWE reaction, which is different from the other methods leading to $Z$ isomers. Due to the steric hindrance (originating from the large side groups), and the stabilized carbanion, the reaction produces Z-cinnamic acids with high yield (>90\%) and stereoselectivity (>90\%), as it is shown in 4.5.5. The route to the reagents is long (1-2 week), but if one searches for appropriate methods, it is possible to access the reagents at acceptable cost. The method requires special conditions, but if the reaction is well controlled, the $Z$-selectivity can be as high as $97 \%$, and the method works well with each heterocyclic carboxaldehyde; therefore, the HWE reaction, applying the Ando reagent is found to be a general method for the preparation of Z-3-heteroaryl cinnamic acids. 


\subsubsection{Summary of the synthetic methods for $\alpha$-substituted cinnamic acid derivatives}

As it was mentioned in the experimental part, the thienyl-substituted variants were available through the modified Perkin condensation with acceptable yield (34-67\%). The stereoismers can be separated via column chromatography and selective precipitation methods.

The modified Perkin reaction was also tested for the preparation of pyridylsubstituted derivatives, and Z-2-(3-pyridyl)-3-phenylpropenoic acid could be synthesized successfully, although with unacceptably low (5\%) yield. Therefore, other methods were tried and the HWE reaction seemed to be a choice in this case as well. The yield was 78\% for E-Z-2-phenyl-3-(3-pyridyl)propenoic acid, and the isomer distribution was ?. The general approach to the HWE reagent (both pyridyl- and phenyl phosphonoacetates) are similar to the already mentioned Ando and Still-Gennari reagents, and the route to the compound was also long; nevertheless, the final condensation reaction performed well and the processing of the reaction mixture was uncomplicated, thus, this method is more suitable for the preparation of the pyridyl derivatives than the modified Perkin condensation. To sum up, the HWE method can be applied for the synthesis of every possible E-Z-2-(x-pyridyl)-3-(x-pyridyl)propenoic acid.

\subsection{Determining the different hydrogen bonds with infrared spectroscopy}

IR spectroscopy was applied to identify the strong cyclic double $\mathrm{C}=\mathrm{O} \ldots \mathrm{H}-\mathrm{O}$ hydrogen bonds between the carboxylic groups. The very typical, wide $\mathrm{O}-\mathrm{H}$ stretching vibration shows up in the $2800-3500 \mathrm{~cm}^{-1}$ region when the $\mathrm{O}-\mathrm{H}$...O hydrogen bonds are present, and forms a sharp peak around $3600 \mathrm{~cm}^{-1}$ when the $0-\mathrm{H}$ group is not involved in hydrogen bonding. We know from our previous studies that each cinnamic acid derivative forms hydrogen-bonded cyclic dimers, just like any other carboxylic acid, in the solid state and also in the liquid phase when aprotic solvent is used. The weaker hydrogen bonds can be identified from the displacement of the (aromatic)C-H...X and/or (olfenic)C-H... X vibrations; however, these changes may also belong to $\pi$-stacking interactions.

The solid state infrared spectra of the studied materials are shown from Figure 47 to Figure 50. 
The spectra of the furyl, thienyl and selenophenyl derivatives (Figure 47) look very similar: the pristine acids (both $E$ and $Z$ isomers) form hydrogen-bonded dimers $(\mathrm{O}-\mathrm{H} \ldots \mathrm{O}=\mathrm{C})$ indicated by the wide $\mathrm{O}-\mathrm{H}$ stretching vibration appearing around 2500-3000 $\mathrm{cm}^{-1}$, and the same vibration disappears if the acidic protons are no longer present (in the sodium salt of the materials). All studied materials have common vibrations regardless of the form (acid or sodium salt) like the strong $\mathrm{C}=0$ stretching at
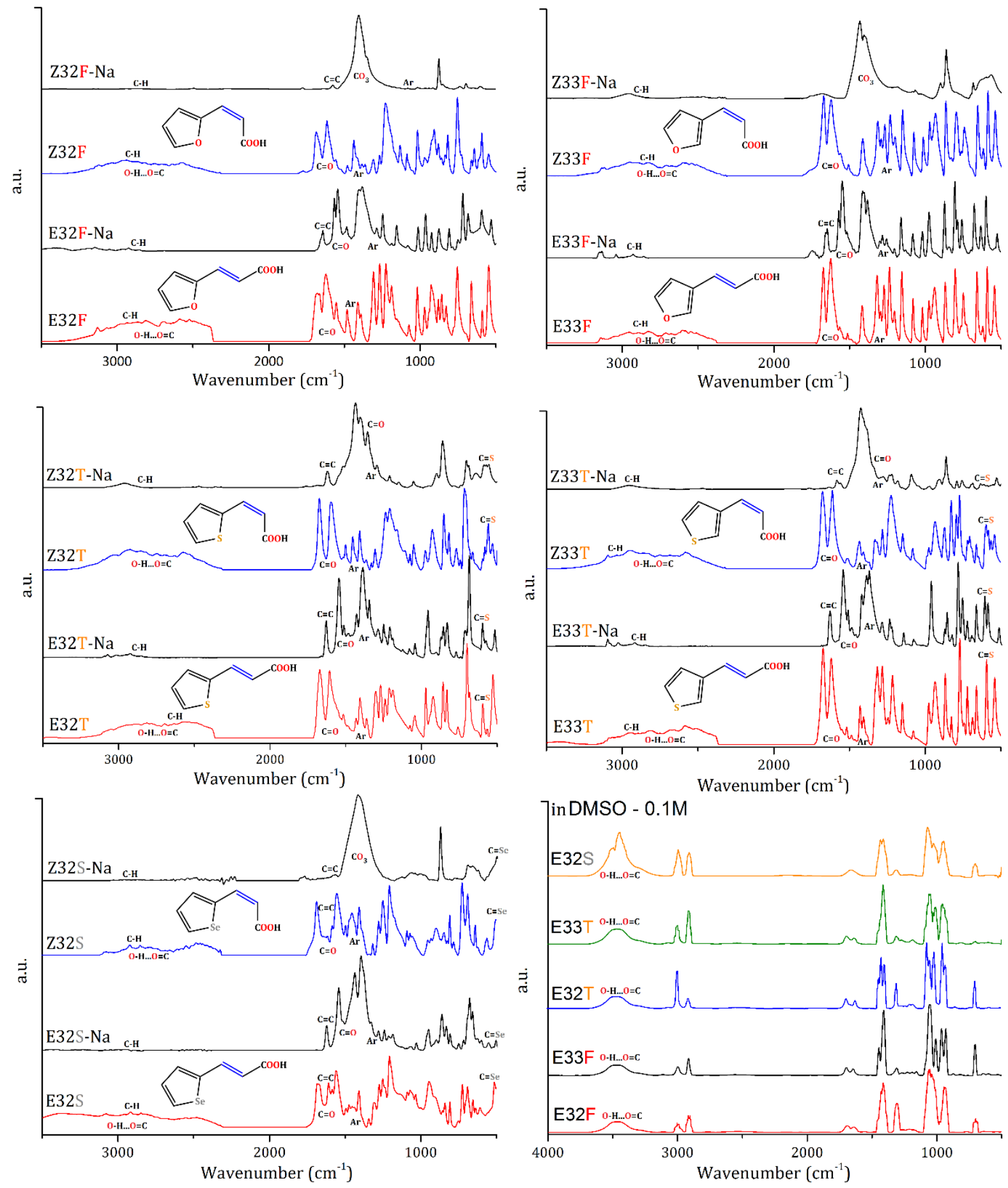

Figure 47 The solid and liquid state IR spectra of the furyl-, thienyl-and selenophenyl-derivatives 
$1600 \mathrm{~cm}^{-1}$, the olefinic $\mathrm{C}=\mathrm{C}$ at $1700 \mathrm{~cm}^{-1}$, the aromatic skeleton vibrations under 1500 $\mathrm{cm}^{-1}$ or the $\mathrm{C}-\mathrm{H}$ stretching around $3000 \mathrm{~cm}^{-1}$ as it indicated in the spectra. Some identical vibrations can be assigned as well, like the different bending of the aromatic rings under $800 \mathrm{~cm}^{-1}$, where the heteroatom-carbon atom deformations provide with assignable peaks [C-S, C-Se, Pyr(pyridine ring bending)].The liquid-state spectra of the $E$ isomers, in DMSO are registered as well to check the presence of the double hydrogenbonds in solution. As it is seen, the wide absorption band, indicative of hydrogen bonding interaction, appears around $3500 \mathrm{~cm}^{-1}$. Sharp $\mathrm{O}-\mathrm{H}$ vibrations were not found, which means the fundamental unit is the dimer in aprotic solvents, thus, hydrogen bonding interactions can be studied in aprotic dipolar media like DMSO. However, the absorption of the solvent is very intense in a wide frequency range, overlapping with the aromatic region making the identification of vibration band displacement at least very difficult if not impossible. A compromise, working in many cases, is the use of chloroform, which has a spectrum significantly poorer in vibrations in the mid-IR range, and can dissolve many but not all of our compounds in appreciable amounts. Unfortunately, some of the molecules studied are nearly insoluble in this solvent (pyridyl- and $\alpha$-substituted pyridyl derivatives). In these cases, DMSO was chosen as the solvent, and NMR spectroscopy was applied for studying hydrogen bonding interactions instead of IR spectroscopy.

The band indicative of the hydrogen bonds between the carboxylic groups disappeared from the spectra of the pristine pyridylpropenoic acids (Figure 48) (both $E$ and $Z$ isomers), and a new vibration showed up at $2500 \mathrm{~cm}^{-1}$, which can be assigned to quaternary $\mathrm{N}^{+}-\mathrm{H}$ stretching. This means the pyridyl-derivatives exist as zwitterions, which not so surprising, because the pyridyl-ring has basic character and a proton is easily transferred from the carboxylic group of another pyridylpropenoic acid. Only the E32P variant shows some dimerization. In the hydrochloric salt, the carboxylate group is forced to keep its proton, thus, dimerization occurs again, as it is seen in Figure 48. 


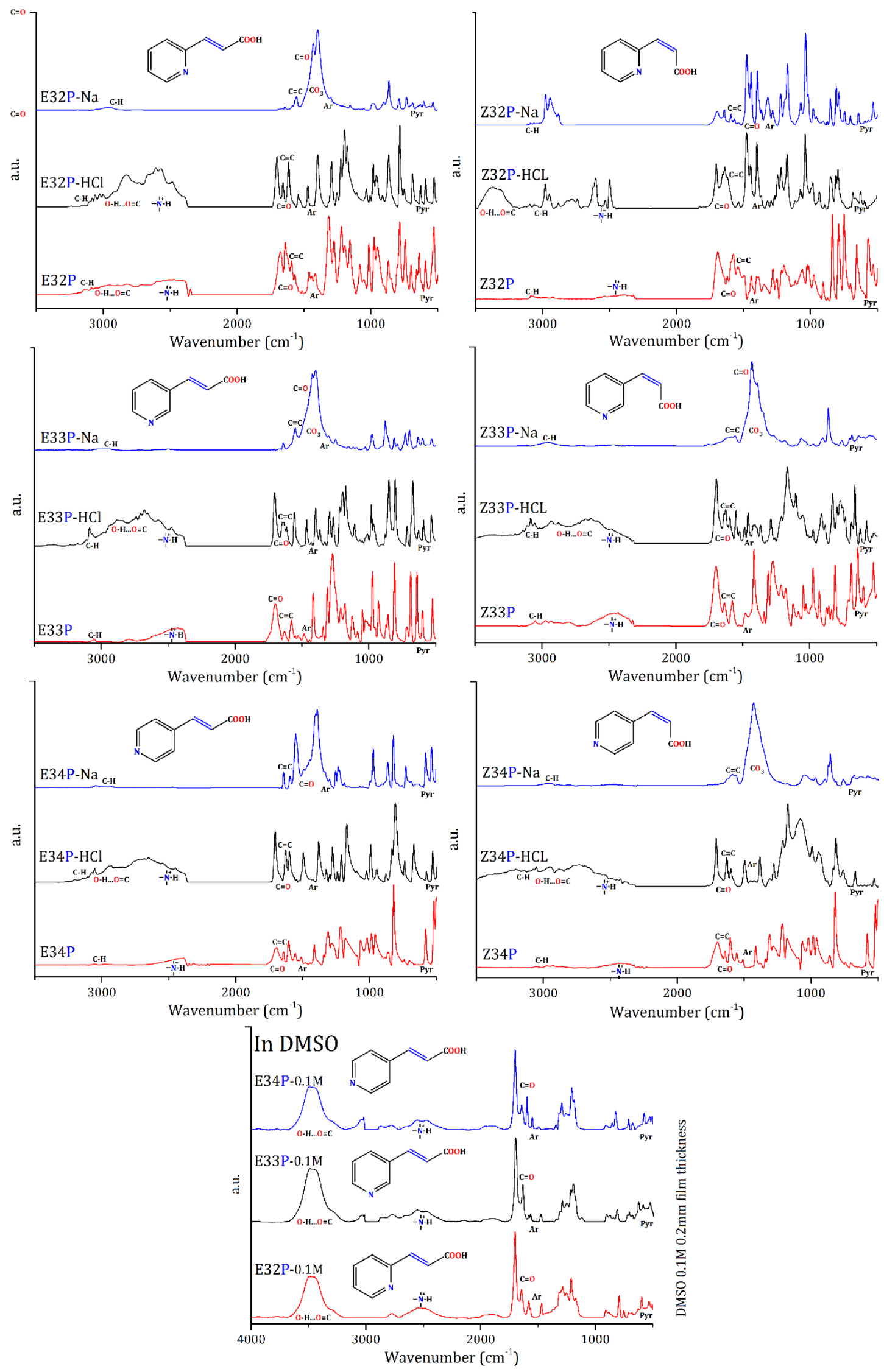

Figure 48 The solid- and the liquid-state IR spectra of the pyridylcinnamic acids 
The $\alpha$-substituted thienylcinnamic acid derivatives show very similar results to those seen for the unsubstituted cinnamic acid analogs containing five-membered heterocycles. The typical wide $\mathrm{O}-\mathrm{H} \ldots \mathrm{O}=\mathrm{C}$ vibration, the sign of hydrogen-bonded dimers, appears in all cases, and the shape of the absorption shows consistency with the geometry of the proper isomer (Figure 49). The changes in the shape of the band are rooted in the presence or lack of steric hindrance between the molecules. If the aromatic rings are on the same side of the molecule, they do not interfere with the other parts of the molecule during the formation of the dimer; however, if they are on different sides $(Z$ isomers), the intermolecular interactions become predominant, leading to a more regulated crystal structure, yielding narrow $\mathrm{O}-\mathrm{H} . . \mathrm{O}=\mathrm{C}$ vibration. The spectra of the compounds were registered in solution as well. The solvent was chloroform and the concentrations varied in the $10^{-2}-10^{-4}$ range. As one can see in Figure 49, the aromatic vibrations and the $\mathrm{C}=\mathrm{S}-\mathrm{C}$ vibrations of the thienyl group are shifted with $5-10 \mathrm{~cm}^{-1}$ to the lower energies with dilution, which means that aromatic and/or olefinic C-H...S interactions prevail in concentrated solutions and in the solid state. 

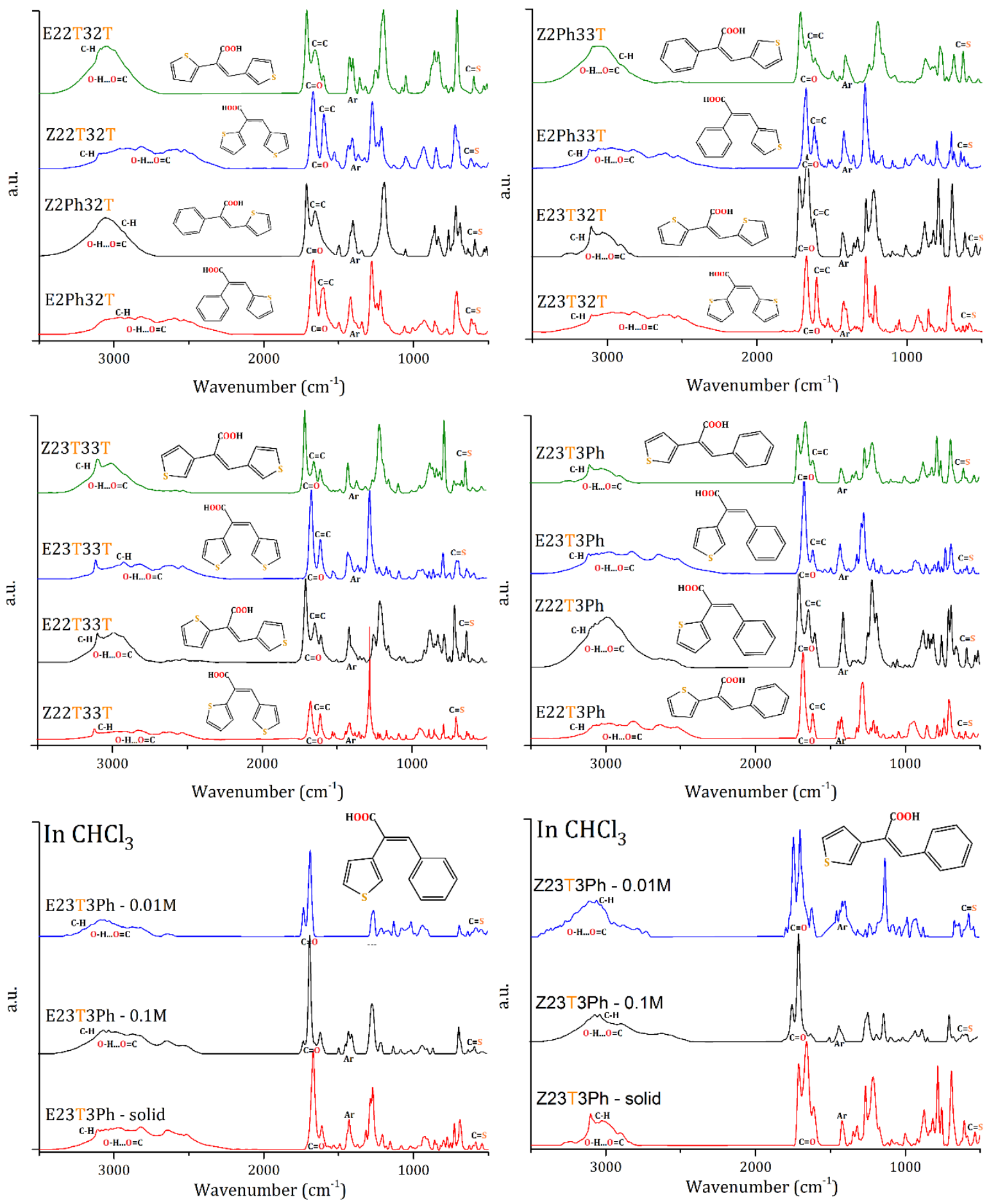

Figure 49 The solid- and the liquid-state IR spectra of the $\alpha$-substituted thienylcinnamic acids

The family of the $\alpha$-substituted pyridylcinnamic acid molecules shows full consistency with the pyridylcinnamic acids. The IR spectra of the studied derivatives are shown in Figure 50. The practically exclusive structure in the solid state is the zwitterion, just as it was seen for the (unsubstituted) pyridylcinnamic acids. However, for the E2Ph33P isomer dissolved in DMSO, dimerization is the exclusive process (the vibration 
of the quaternary nitrogen vanished from the spectra); therefore, aggregation via the weaker $\mathrm{C}-\mathrm{H}$...N interactions becomes possible.

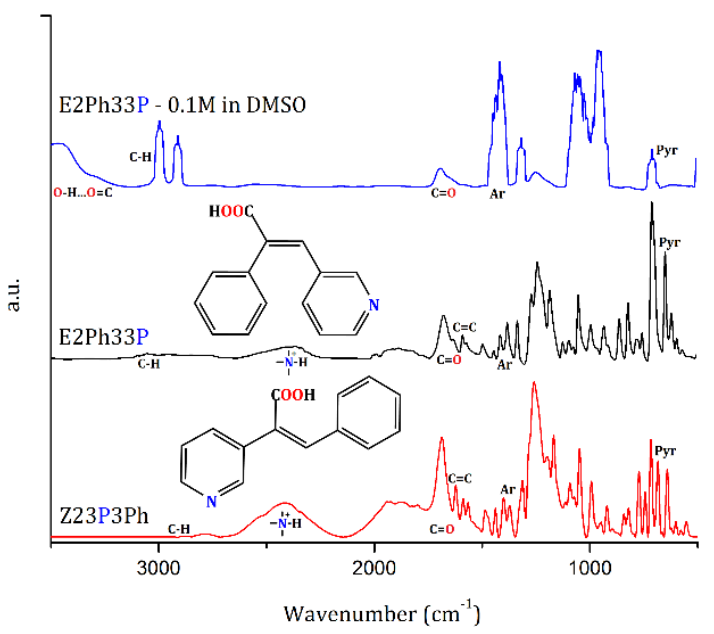

Figure 50 The solid- and liquid-state IR spectra of the $\alpha$-substituted pyridylcinnamic acids

To sum up, it has been found that the fundamental unit is the double hydrogenbonded cyclic dimer in the solid state for the five-membered derivatives and the zwitterion for the pyridyl derivatives; however, they can form dimers in DMSO; therefore, the further investigations the interactions between the dimers are feasible. Based on the experimental findings, the hydrogen-bonded dimers are used as fundamental units in the quantum chemical modelling as well.

\section{$5.3{ }^{1}{ }^{1}-1 H^{1}$ correlation (COSY) and nuclear Overhauser effect (NOESY) NMR spectra of heteroaryl cinnamic acids}

As was seen in the IR spectra of the studied materials, the fundamental unit is the hydrogen-bonded dimers kept together via strong $\mathrm{O}-\mathrm{H} . . . \mathrm{O}=\mathrm{C}$ cyclic hydrogen bonds in most cases. The pyridyl derivatives only act differently in the solid state; nevertheless, they also form the cyclic dimers in dipolar aprotic solvent like DMSO. 


\begin{tabular}{|c|c|c|c|c|c|c|}
\hline Compound & H1 & H2 & H3 & H4 & H5 & $-\mathrm{COO}-\mathrm{H}$ \\
\hline & $\begin{array}{c}8.19, \mathrm{~d} \\
\mathrm{~J}=1.2 \mathrm{~Hz}\end{array}$ & $\begin{array}{c}7.00, \mathrm{dd} \mathrm{J}_{\mathrm{A}}=1.5 \mathrm{~Hz}, \mathrm{~J}_{\mathrm{B}} \\
=2.8 \mathrm{~Hz}\end{array}$ & $\begin{array}{c}\text { 7.29-7.30, d } \\
J=2.7 \mathrm{~Hz}\end{array}$ & $\begin{array}{c}7.79-7.82, \mathrm{~d} \\
\mathrm{~J}=15.5 \mathrm{~Hz}\end{array}$ & $\begin{array}{c}6.57-6.61, d \\
J=15.5 \mathrm{~Hz}\end{array}$ & 12.77 \\
\hline соон & $\begin{array}{c}\text { 7.76, d } \\
J=1.1 \mathrm{~Hz}\end{array}$ & $\begin{array}{c}6.60, \mathrm{dd} \\
\mathrm{J}_{\mathrm{A}}=1.3 \mathrm{~Hz}, \mathrm{~J}_{\mathrm{B}}=2.5 \mathrm{~Hz}\end{array}$ & $\begin{array}{c}7.50-7.51, \mathrm{~d} \\
\mathrm{~J}=2.7 \mathrm{~Hz}\end{array}$ & $\begin{array}{c}6.79-6.81, \mathrm{~d} \\
\mathrm{~J}=12.8 \mathrm{~Hz}\end{array}$ & $\begin{array}{c}5.73-5.75, \mathrm{~d} \\
\mathrm{~J}=12.8 \mathrm{~Hz}\end{array}$ & 12.41 \\
\hline & $8.02, \mathrm{~s}(\mathrm{br})$ & 7.67, s (br) & 6.87, s (br) & $\begin{array}{c}7.47-7.50, \mathrm{~d} \\
\mathrm{~J}=15.8 \mathrm{~Hz}\end{array}$ & $\begin{array}{c}6.20-6.23 \\
J=15.8 \mathrm{~Hz}\end{array}$ & 12.35 \\
\hline$\left.\right|_{\text {соон }} ^{5}$ & 7.67, s (br) & $8.22, \mathrm{~s}(\mathrm{br})$ & 7.02, s (br) & $\begin{array}{c}6.77-6.79, \mathrm{~d} \\
\mathrm{~J}=12.8 \mathrm{~Hz}\end{array}$ & $\begin{array}{c}5.74-5.77 \\
J=12.8 \mathrm{~Hz}\end{array}$ & 12.31 \\
\hline & $\begin{array}{c}6.86-6.87, \mathrm{~d} \\
\mathrm{~J}=4.2 \mathrm{~Hz}\end{array}$ & $\begin{array}{c}\text { 6.30-6.31, dd } \\
\mathrm{J}_{A}=2.5 \mathrm{~Hz}, \mathrm{~J}_{\mathrm{B}}=3.9 \mathrm{~Hz}\end{array}$ & $\begin{array}{c}\text { 6.67, d } \\
J=2.7 \mathrm{~Hz}\end{array}$ & $\begin{array}{c}6.89-6.92, \mathrm{~d} \\
\mathrm{~J}=15.8 \mathrm{~Hz}\end{array}$ & $\begin{array}{c}5.33-5.36, \mathrm{~d} \\
\mathrm{~J}=15.8 \mathrm{~Hz}\end{array}$ & 11.55 \\
\hline & $\begin{array}{c}7.73, \mathrm{~d} \\
J=3.2 \mathrm{~Hz}\end{array}$ & $\begin{array}{c}7.09, \mathrm{dd} \\
\mathrm{J}_{\mathrm{A}}=3.1 \mathrm{~Hz}, \mathrm{~J}_{\mathrm{B}}=3.4 \mathrm{~Hz}\end{array}$ & $\begin{array}{c}7.53, \mathrm{~d} \\
\mathrm{~J}=3.6 \mathrm{~Hz}\end{array}$ & $\begin{array}{c}7.19-7.22, \mathrm{~d} \\
\mathrm{~J}=12.2 \mathrm{~Hz}\end{array}$ & $\begin{array}{c}5.69-5.72, \mathrm{~d} \\
\mathrm{~J}=12.2 \mathrm{~Hz}\end{array}$ & 12.37 \\
\hline & $\begin{array}{c}7.52-7.53, \mathrm{dd} \\
\mathrm{J}_{A}=4.8 \mathrm{~Hz}, \mathrm{~J}_{B}=2.6 \mathrm{~Hz}\end{array}$ & $\begin{array}{c}\text { 7.86, d } \\
J=2.3 \mathrm{~Hz}\end{array}$ & $\begin{array}{c}7.47-7.48, \mathrm{~d} \\
\mathrm{~J}=4.8 \mathrm{~Hz}\end{array}$ & $\begin{array}{c}7.58-7.62, \mathrm{~d} \\
J=16.1 \mathrm{~Hz}\end{array}$ & $\begin{array}{c}6.34-6.37, \mathrm{~d} \\
J=16.1 \mathrm{~Hz}\end{array}$ & 12.27 \\
\hline & $7.55, \mathrm{~s}(\mathrm{br})$ & $8.10, \mathrm{~s}(\mathrm{br})$ & 7.51, s (br) & $\begin{array}{c}6.88-6.91, \mathrm{~d} \\
\mathrm{~J}=12.5 \mathrm{~Hz}\end{array}$ & $\begin{array}{c}5.77-5.80, \mathrm{~d} \\
\mathrm{~J}=12.5 \mathrm{~Hz}\end{array}$ & 12.35 \\
\hline & $\begin{array}{c}8.28, \mathrm{~d} \\
\mathrm{~J}=4.5 \mathrm{~Hz}\end{array}$ & 7.31, s (br) & $7.63, \mathrm{~s}(\mathrm{br})$ & $\begin{array}{c}7.72-7.75, \mathrm{~d} \\
\mathrm{~J}=15.2 \mathrm{~Hz}\end{array}$ & $\begin{array}{c}6.07-6.10, d \\
J=15.2 \mathrm{~Hz}\end{array}$ & 12.39 \\
\hline$\left.\mathbb{1}_{-\mathrm{Se}}^{\mid \mathrm{z32S}}\right|_{\text {Соон }}$ & $\begin{array}{c}8.25, \mathrm{~d} \\
\mathrm{~J}=5.1 \mathrm{~Hz}\end{array}$ & $\begin{aligned} & 7.59-7.60, \mathrm{dd} \\
\mathrm{J}_{\mathrm{A}}= & 5.4 \mathrm{~Hz}, \mathrm{~J}_{\mathrm{B}}=3.3 \mathrm{~Hz}\end{aligned}$ & $\begin{array}{c}\text { 7.37-7.38, d } \\
J=3.5 \mathrm{~Hz}\end{array}$ & $\begin{array}{c}7.28-7.31, \mathrm{~d} \\
\mathrm{~J}=11.9 \mathrm{~Hz}\end{array}$ & $\begin{array}{c}5.68-5.70, \mathrm{~d} \\
\mathrm{~J}=11.9 \mathrm{~Hz}\end{array}$ & 12.20 \\
\hline
\end{tabular}

Table $8{ }^{1} \mathrm{H}$ NMR assignements for the five-membered heteroaryl cinnamic acid derivatives in DMSO- $\mathrm{d}_{6}$ 


\begin{tabular}{|c|c|c|c|c|c|c|c|}
\hline Compound & H1 & H2 & H3 & H4 & H5 & H6 & $-\mathrm{COO}-\mathrm{H}$ \\
\hline $\mathbf{E}$ & $\begin{array}{c}8.59-8.60, \mathrm{~d} \\
\mathrm{~J}=4.2 \mathrm{~Hz}\end{array}$ & $\begin{array}{c}7.40-7.43, \mathrm{ddd} \\
\mathrm{J}_{\mathrm{A}}=4.6 \mathrm{~Hz}, \mathrm{~J}_{\mathrm{B}}=6.4 \mathrm{~Hz},\left(\mathrm{~J}_{\mathrm{C}}=0.9\right. \\
\mathrm{Hz})\end{array}$ & $\begin{array}{c}7.87-7.89, \mathrm{dt} \\
\mathrm{J}_{A}=7.7 \mathrm{~Hz}, \mathrm{~J}_{B}= \\
6.2 \mathrm{~Hz}\end{array}$ & $\begin{array}{c}\text { 7.68-7.69, d } \\
J=7.6 \mathrm{~Hz}\end{array}$ & $\begin{array}{l}7.56-7.59, \mathrm{~d} \\
\mathrm{~J}=15.9 \mathrm{~Hz}\end{array}$ & $\begin{array}{c}6.83-6.86, d \\
J=15.9 \mathrm{~Hz}\end{array}$ & 12.43 \\
\hline & $\begin{array}{c}8.71-8.73, \mathrm{~d} \\
\mathrm{~J}=4.2 \mathrm{~Hz}\end{array}$ & $\begin{aligned} & 7.59-7.61, \mathrm{dd} \\
\mathrm{J}_{\mathrm{A}}= & 4.7 \mathrm{~Hz}, \mathrm{~J}_{\mathrm{B}}=5.7 \mathrm{~Hz}\end{aligned}$ & $\begin{array}{c}8.12-8.13, \mathrm{dt} \\
\mathrm{J}_{A}=7.5 \mathrm{~Hz}, \mathrm{~J}_{B}= \\
5.8 \mathrm{~Hz}\end{array}$ & $\begin{array}{c}\text { 7.76-7.78, d } \\
J=7.6 \mathrm{~Hz}\end{array}$ & $\begin{array}{l}\text { 7.03-7.06, d } \\
J=13.1 \mathrm{~Hz}\end{array}$ & $\begin{array}{c}6.14-6.17, d \\
J=13.1 \mathrm{~Hz}\end{array}$ & 12.22 \\
\hline & $8.82, \mathrm{~s}(\mathrm{br})$ & $\begin{array}{c}8.55-8.56, d \\
J=4.2 \mathrm{~Hz}\end{array}$ & $\begin{array}{c}7.40-7.42, \mathrm{dd} \\
\mathrm{J}_{A}=7.6 \mathrm{~Hz}, \mathrm{~J}_{B}= \\
4.5 \mathrm{~Hz}\end{array}$ & $\begin{array}{c}8.11-8.13, \mathrm{~d} \\
\mathrm{~J}=7.8 \mathrm{~Hz}\end{array}$ & $\begin{array}{c}7.59-7.62, \mathrm{~d} \\
\mathrm{~J}=16.1 \mathrm{~Hz}\end{array}$ & $\begin{array}{c}6.64-6.67, \mathrm{~d} \\
\mathrm{~J}=16.1 \mathrm{~Hz}\end{array}$ & 12.54 \\
\hline & 8.67, s (br) & $\begin{array}{c}8.49-8.48, \mathrm{~d} \\
\mathrm{~J}=3.5 \mathrm{~Hz}\end{array}$ & $\begin{array}{c}\text { 7.37-7.38, d (br), } \\
J=6.8 \mathrm{~Hz}\end{array}$ & $\begin{array}{c}8.00-8.02, \mathrm{~d} \\
\mathrm{~J}=7.4 \mathrm{~Hz}\end{array}$ & $\begin{array}{l}6.95-6.98, \mathrm{~d} \\
\mathrm{~J}=12.5 \mathrm{~Hz}\end{array}$ & $\begin{array}{c}6.06-6.09, \mathrm{~d} \\
\mathrm{~J}=12.5 \mathrm{~Hz}\end{array}$ & 12.53 \\
\hline E34P & $\begin{array}{c}7.49-7.52, \mathrm{~d} \\
\mathrm{~J}=3.9 \mathrm{~Hz}\end{array}$ & $\begin{array}{c}7.60-7.61, \mathrm{~d} \\
\mathrm{~J}=3.8 \mathrm{~Hz}\end{array}$ & $\begin{array}{c}7.60-7.61, \mathrm{~d} \\
\mathrm{~J}=3.8 \mathrm{~Hz}\end{array}$ & $\begin{array}{c}7.49-7.52, \mathrm{~d} \\
\mathrm{~J}=3.9 \mathrm{~Hz}\end{array}$ & $\begin{array}{l}7.49-7.52, \mathrm{~d} \\
\mathrm{~J}=16.1 \mathrm{~Hz}\end{array}$ & $\begin{array}{c}6.70-6.74, \mathrm{~d} \\
\mathrm{~J}=16.1 \mathrm{~Hz}\end{array}$ & 12.36 \\
\hline Z34P & $\begin{array}{c}8.41-8.42, \mathrm{~d} \\
\mathrm{~J}=4.1 \mathrm{~Hz}\end{array}$ & $\begin{array}{c}7.20-7.21, \mathrm{~d} \\
\mathrm{~J}=4.2 \mathrm{~Hz}\end{array}$ & $\begin{array}{c}7.20-7.21, \mathrm{~d} \\
\mathrm{~J}=4.2 \mathrm{~Hz}\end{array}$ & $\begin{array}{c}8.41-8.42, \mathrm{~d} \\
\mathrm{~J}=4.1 \mathrm{~Hz}\end{array}$ & $\begin{array}{c}6.86-6.89, \mathrm{~d} \\
\mathrm{~J}=12.2 \mathrm{~Hz}\end{array}$ & $\begin{array}{c}6.15-6.17, \mathrm{~d} \\
\mathrm{~J}=12.2 \mathrm{~Hz}\end{array}$ & 12.48 \\
\hline
\end{tabular}

Table $9{ }^{1} \mathrm{H}$ NMR assignements of the pyridylcinnamic acids in DMSO-d 6 
The complete proton assignments of the studied molecules are shown in Table 8, Table 9 and Table 10. As it can be seen, the acidic protons of the carboxyl groups are present in each spectrum, even for the pyridylcinnamic acids, where this peak is detectable for E32P, Z32P, E34P and Z34P and is sharp for E33P, Z33P, E2Ph33P and Z23P3Ph. This is another evidence for the presence of the cyclic dimers in the solution. Moreover, the peaks of the aromatic protons are unusually broadened (deconvolution was needed sometimes to resolve the broad peaks) compared to the phenyl derivatives, and ddd (doublets of double doublets) couplings, which would be a sign of complex interactions, were very rarely found (E32P). However, the signal broadening and the dislocation of the peaks did not provide enough evidence for the presence of weak hydrogen bonds; therefore, ${ }^{1} \mathrm{H}-1 \mathrm{H}$ correlation spectroscopy (COSY) was chosen to clearly identify interactions like these. The COSY method, reveal the couplings between the neighboring protons as strong, off-diagonal peaks. Coupling with the second and third neighbor can be detected as well; however, these peaks are very small. If weak hydrogen bonds are present among the molecules, couplings with the second or the third neighbor (in the heteroaromatic rings) become stronger. To avoid confusion between couplings originating from covalently-bonded and hydrogen-bonded systems, coupling between the first olefinic proton and the closest aromatic proton ( $\mathrm{H} 3-\mathrm{H} 4$ for the five-membered derivatives and $\mathrm{H} 4-\mathrm{H} 5$ for the six-membered variants) was chosen as internal reference. The signal level of these coupling was the threshold of the measurements. Every coupling having lower intensities than the reference peak was removed from the spectra (including the reference peak as well) to simplify the understanding of the interactions.

Figure 51 shows the results for the furylcinnamic acid derivatives. Through the combinations of the couplings, only one possible hydrogen-bonded structure can be identified for 3-(2-furyl)cinnamic acids, where the coupling among H1-H3 belongs to the (aromatic)C-H...O-(aromatic)C weak hydrogen bond. For the 3-(3-furyl) derivatives, one more interaction can be assigned via the $\mathrm{H} 1-\mathrm{H} 2$ and the $\mathrm{H} 1-\mathrm{H} 3$ couplings.

The ${ }^{1} \mathrm{H}-1 \mathrm{H}$ COSY spectra of the thienyl variants are shown in Figure 52. The couplings assigned are as follows: $\mathrm{H} 1-\mathrm{H} 3$ for 3-(2-thienyl), $\mathrm{H} 1-\mathrm{H} 2$ and $\mathrm{H} 1-\mathrm{H} 3$ for the 3(3-thienyl) derivatives. Although the (aromatic)C-H...S-(aromatic)C interactions are significantly weaker than the (aromatic)C-H...O-(aromatic)C hydrogen bonds, it is still clearly detectable. 
The weakest interaction was found for the 3-(2-selenophenyl) compounds (Figure 53), where the signal level of the H1-H3 coupling is hardly reaches the selected threshold, which means the (aromatic)C-H...Se-(aromatic)C hydrogen bond is the weakest in the heteroarylcinnamic acid families studied.
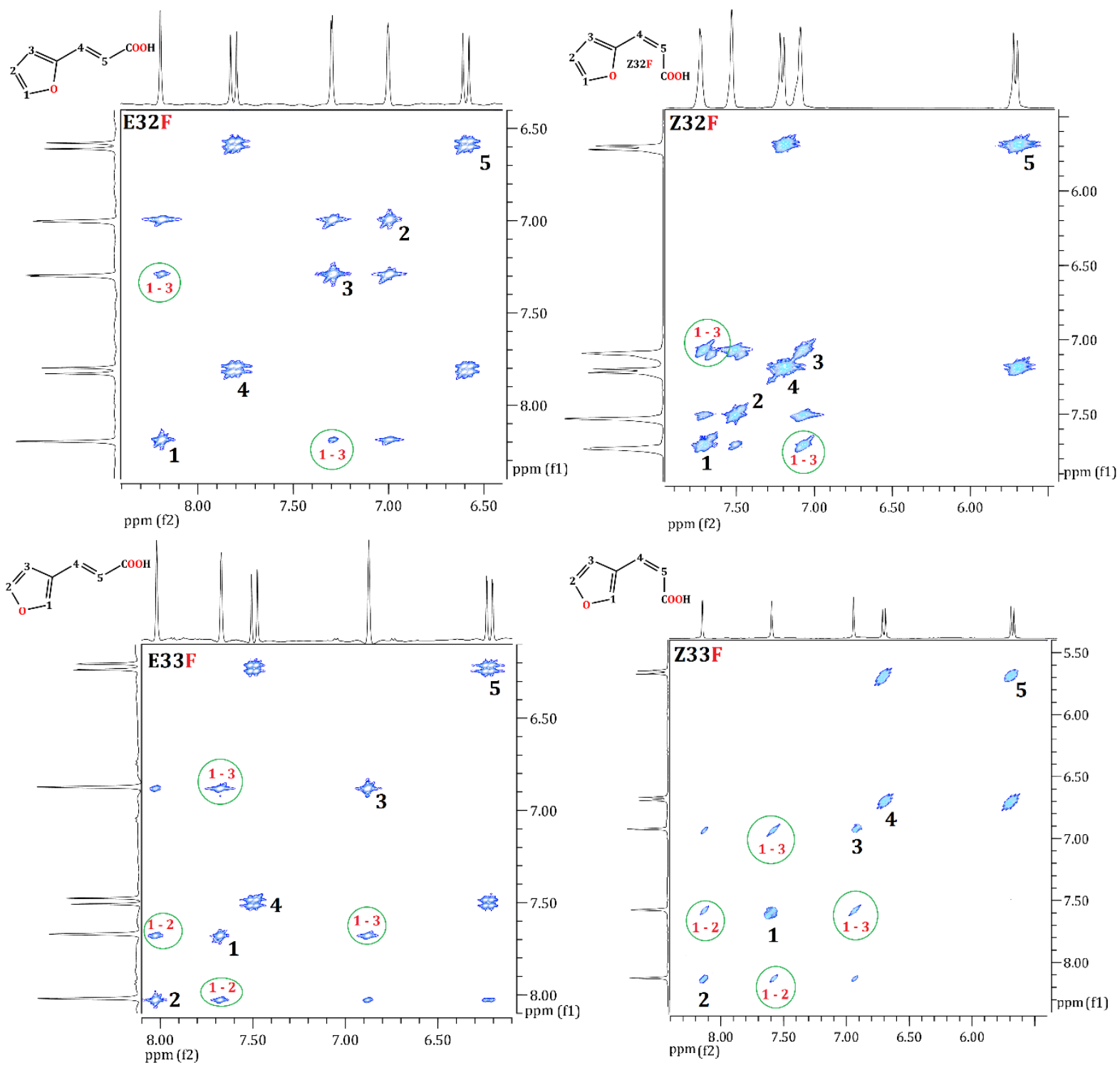

Figure 51 The ${ }^{1} \mathrm{H}-{ }^{1} \mathrm{H}$ COSY NMR spectra of the furylcinnamic acid derivatives 


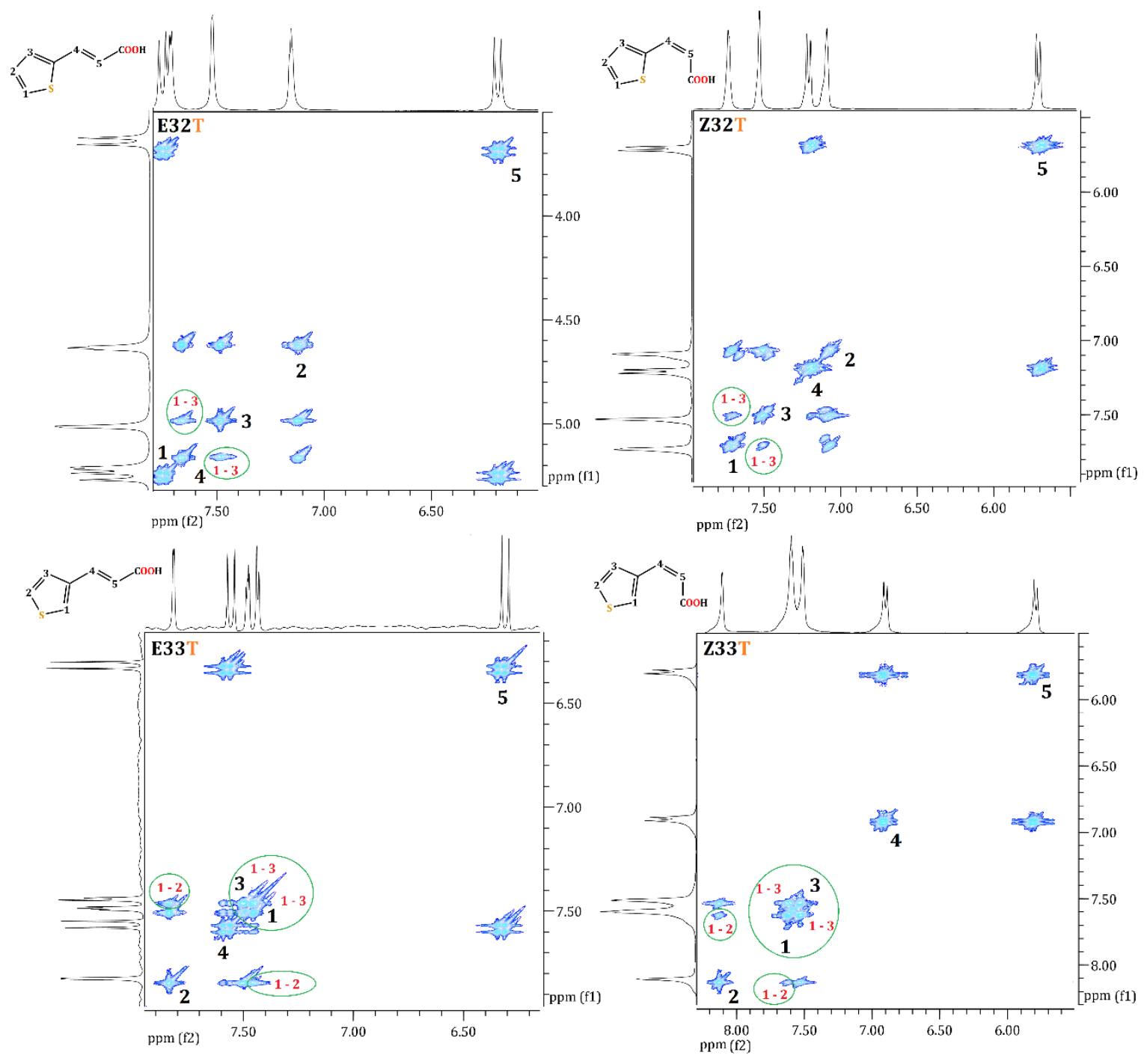

Figure 52 The ${ }^{1} \mathrm{H}-{ }^{1} \mathrm{H}$ COSY NMR spectra of the thienylcinnamic acid derivatives

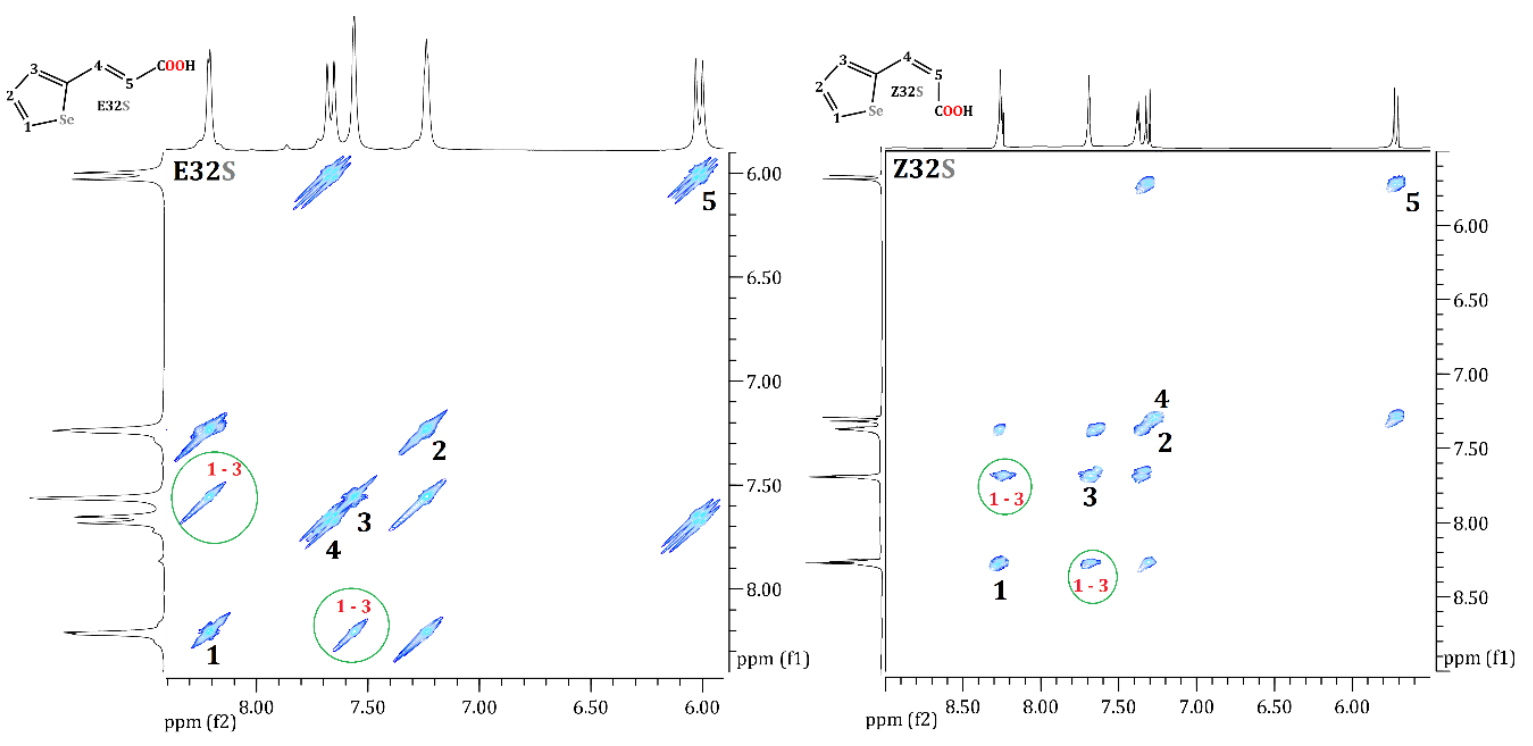

Figure 53 The ${ }^{1} \mathrm{H}-{ }^{1} \mathrm{H}$ COSY NMR spectra of the selenophenylcinnamic acid derivatives 

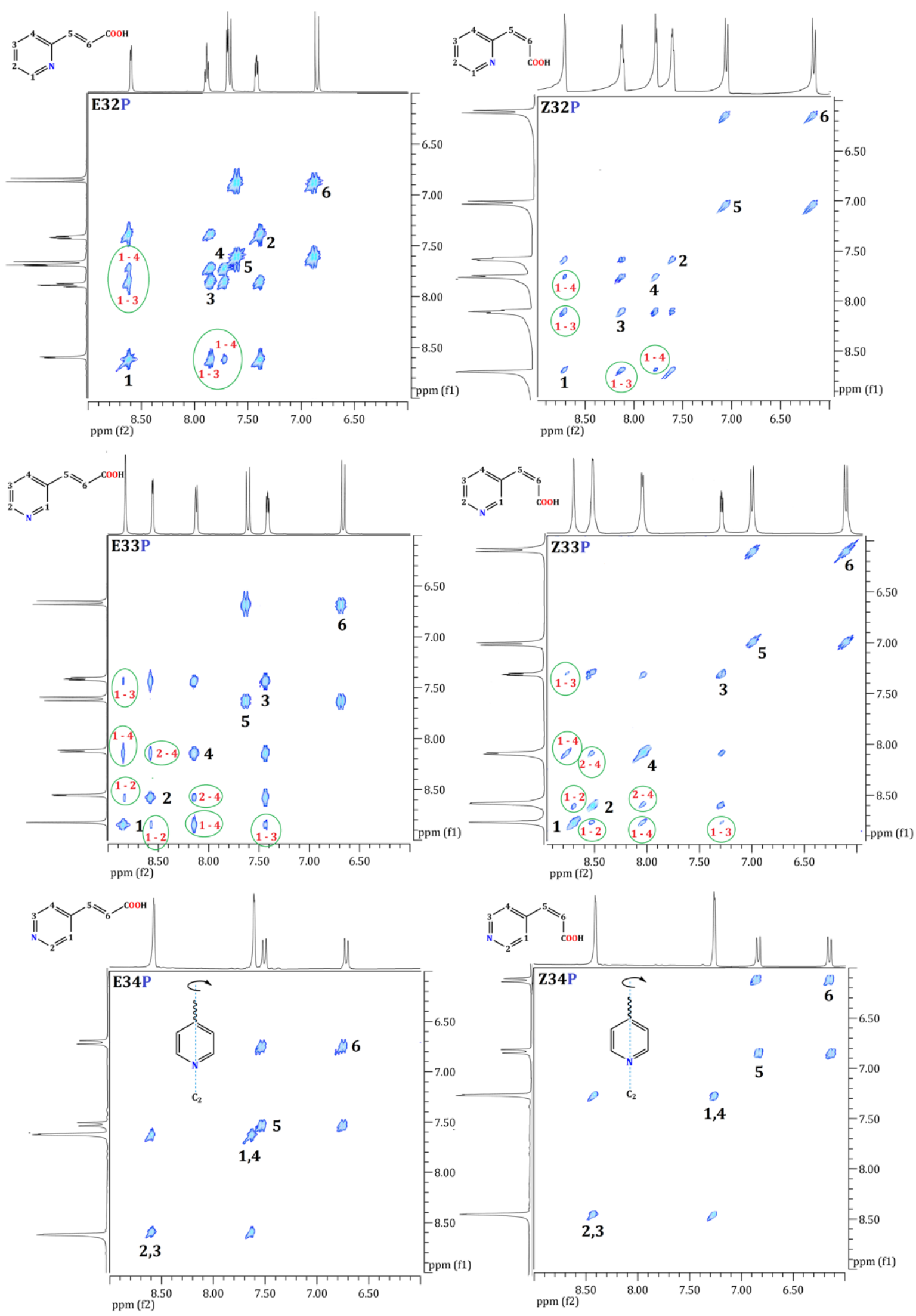

Figure 54 The ${ }^{1} \mathrm{H}-{ }^{1} \mathrm{H}$ COSY NMR spectra of the pyridylcinnamic acid derivatives 
The pyridyl derivatives show much more (aromatic)C-H...N-(aromatic)C interactions (Figure 54) due to the bigger ring size. H1-H3 and $\mathrm{H} 1-\mathrm{H} 4$ couplings are found with intense signals for the 3-(2-pyridyl) variants and $\mathrm{H} 1-\mathrm{H} 2, \mathrm{H} 1-\mathrm{H} 3, \mathrm{H} 1-\mathrm{H} 4$ and H2-H4 couplings with the same parameters for the 3-(3-pyridyl) derivatives. Unfortunately, the pyridine ring of the 3-(4-pyridyl) isomers have $\mathrm{C}_{2}$ symmetry (Figure 54), which means the $\mathrm{H} 1, \mathrm{H} 4$ and $\mathrm{H} 2, \mathrm{H} 3$ protons are magnetically equivalent. Thus, they show only two signals, and these protons are in strong spin-spin couplings, which completely cover any other interactions. However all signals are quite broad, which is a sign of hydrogen bonds, and compared to other pyridyl derivatives, these molecules are the less hindered variants; therefore, the possibility to form cyclic tetramers connected by (aromatic)C-H...N-(aromatic)C weak hydrogen bonds are very feasible. 


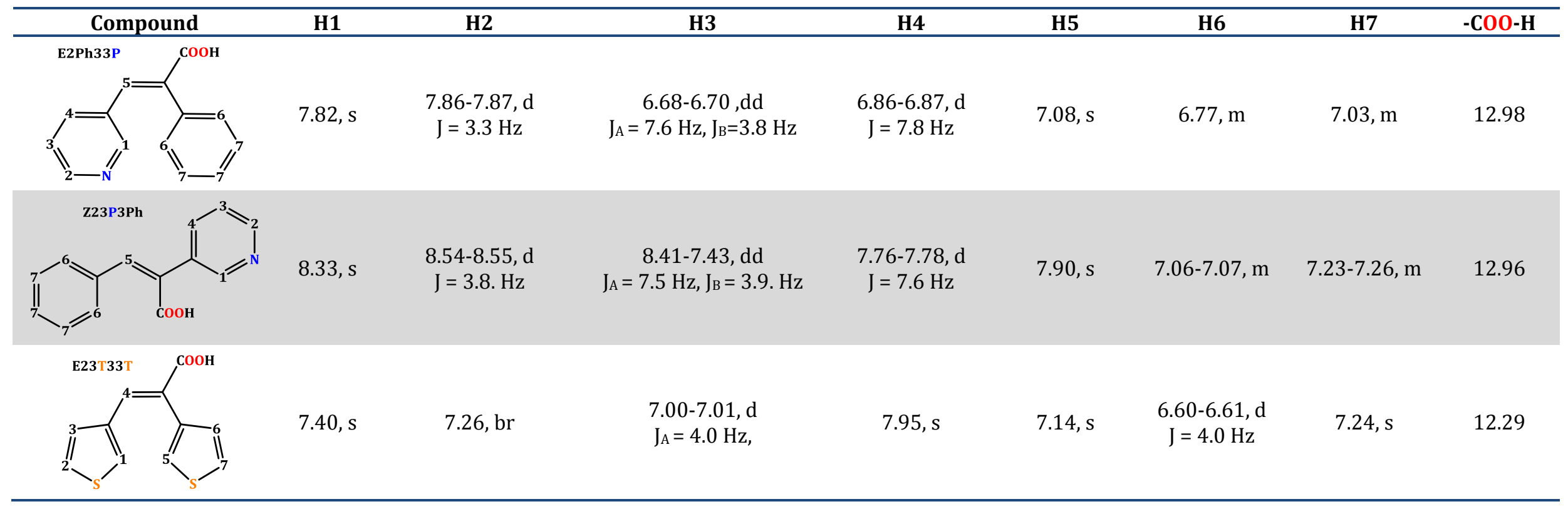

Table $10{ }^{1} \mathrm{H}$ NMR assignements of the studied $\alpha$-substituted cinnamic acids in DMSO-d6 


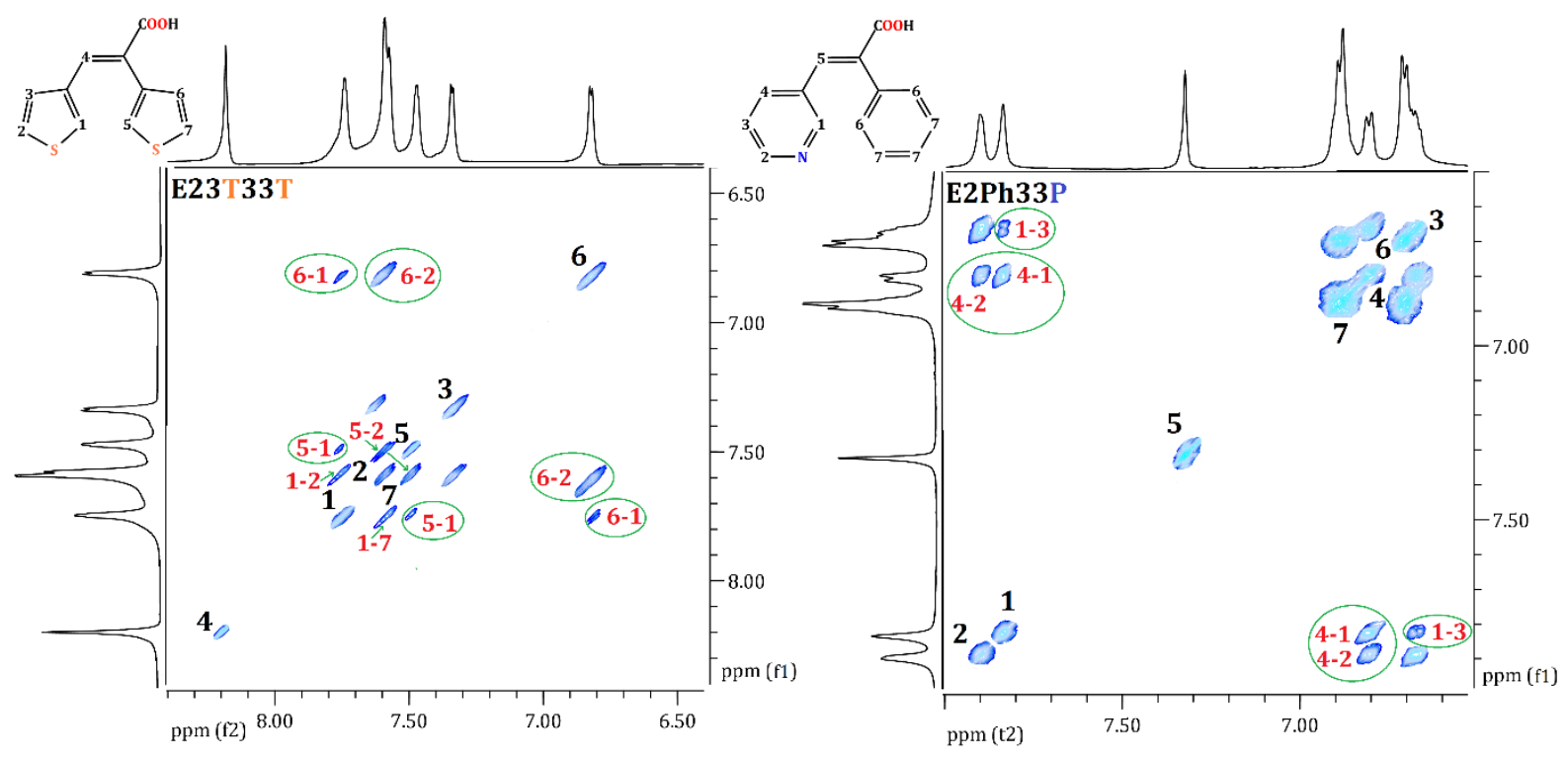

Figure 55 The ${ }^{1} \mathrm{H}-{ }^{1} \mathrm{H}$ COSY NMR spectra of two $\alpha$-substituted cinnamic acid

The previously discussed interactions were found for the $\alpha$-substituted derivatives as well; however, it was not possible to identify each feasible interaction because of the overlapping peaks. For the E23T33T derivative, the couplings among $\mathrm{H} 1-\mathrm{H} 2, \mathrm{H} 1-\mathrm{H} 5, \mathrm{H} 1-\mathrm{H} 6, \mathrm{H} 1-\mathrm{H} 7$ and $\mathrm{H} 2-\mathrm{H} 6$ protons indicated hydrogen bonding interactions. The other example is the E2Ph33P derivative, where the $\mathrm{H} 1-\mathrm{H} 3, \mathrm{H} 1-\mathrm{H} 4$ and $\mathrm{H} 2-\mathrm{H} 4$ couplings, indicating hydrogen bonding interactions, could be identified clearly, and there are ambiguous hints for other interactions as well, e.g. the protons of the phenyl ring may be involved in the hydrogen-bonded system, but due to the overlapping signals we cannot be sure about this interaction.

Utilizing the ${ }^{1} \mathrm{H}-{ }^{1} \mathrm{H}$ nuclear Overhauser effect spectroscopy (NOESY) it was possible to explore the conformational space and properties of the molecules dissolved in various solvent types (DMSO - dipolar, aprotic, $\mathrm{CD}_{3} \mathrm{OD}$ - polar, protic, $\mathrm{CDCl}_{3}$ - close to being completely apolar) using long-range couplings. For cinnamic acids, the coupling between the olefinic and aromatic proton(s) was used to deduce the conformational behavior of the aromatic rings. The results for the first studied molecule, Z23P3Ph that is, are shown in Figure 56. The spectra were recorded in relatively diluted (0.05 M) solution (unlike the COSY experiments) to minimize the possibility of intermolecular interactions. As it is seen, the only clear coupling is between H5-H6. This means that the pyridyl ring can rotate freely and/or it is far from the completely flat structure; while the 
rotation of the phenyl group is hindered or the structure in equilibrium is close to being flat.

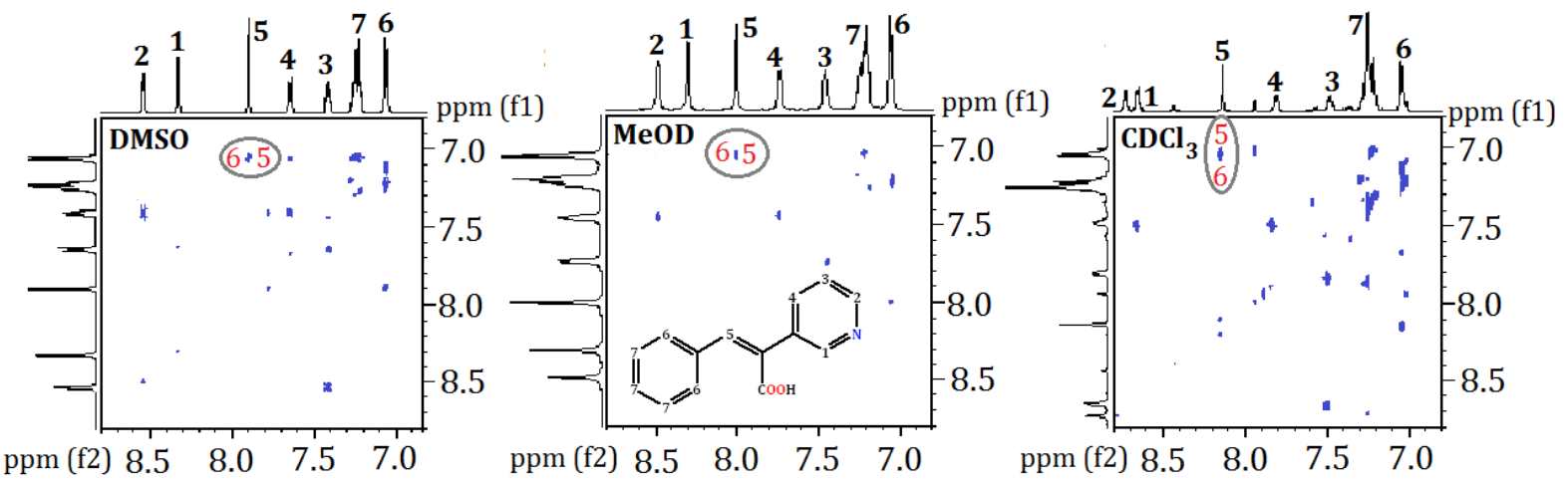

Figure $56{ }^{1}{ }^{\mathrm{H}-1} \mathrm{H}$ NOESY spectra of Z23P3Ph in widely different solvents at $0.05 \mathrm{M}$ concentration

Another example is the ${ }^{1} \mathrm{H}-1 \mathrm{H}$ NOESY spectra of E32P and E34P (Figure 57). Surprisingly, no cross peaks can be detected in the spectra, which means that the aromatic ring is free to rotate between the several possible minima.
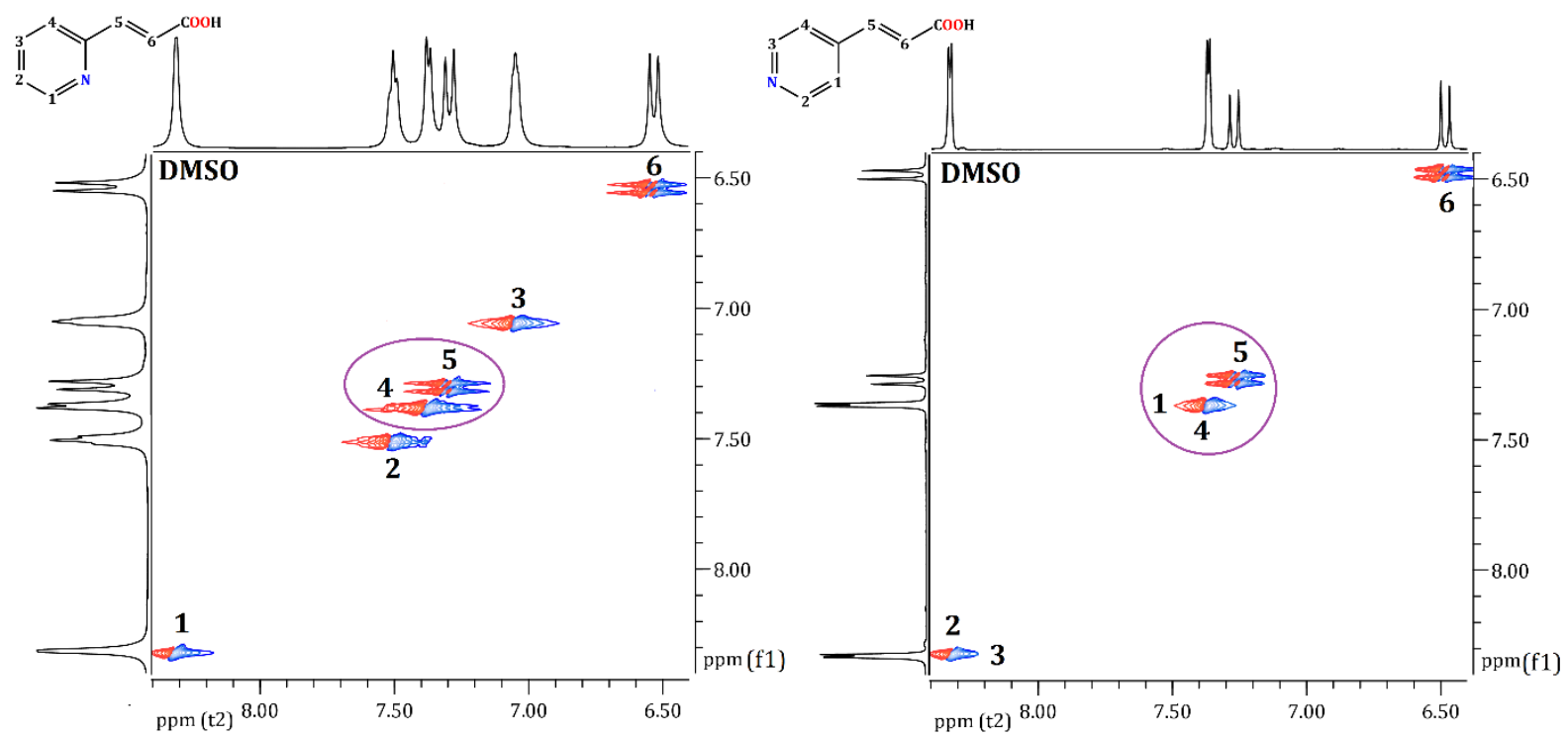

Figure 57 The ${ }^{1} \mathrm{H}^{-1} \mathrm{H}$ NOESY spectra of E32P and E34P in DMSO at $0.05 \mathrm{M}$ concentration

To sum up, it can be stated that many intermolecular hydrogen bonding interactions are possible among each heteroarylcinnamic and $\alpha$-substituted heteroarylcinnamic acids. IR and/or NMR spectroscopies proved to suitable tools for obtaining qualitative, and the intensities of the crosspeaks in the ${ }^{1} \mathrm{H}-{ }^{1} \mathrm{H}$ COSY spectra, semiquantitative information concerning these close contacts. It was found that the 
strength of the (aromatic)C-H...X-(aromatic)C is decreases in the $\mathrm{C}-\mathrm{H} \ldots \mathrm{N}>\mathrm{C}-\mathrm{H} \ldots \mathrm{O}>\mathrm{C}-$ H...S > C-H...Se order. However, for quantitative (energy and geometric) data, quantum chemical calculations are needed (see later: 5.6.2). From the results of the NOESY spectra, it has been established that the rotation is nearly free for each derivative studied; however, for the complete description of the conformational properties, quantum chemical calculations are needed once again (see later: 5.6.1).

\subsection{Identifying the $\pi$-stacking interactions with powder X-ray diffractometry}

The $\pi$-stacking interactions may be present in the liquid and the solid state as well; however, they become only predominant in the crystalline state for small molecules like cinnamic acid derivatives. The appearance of the studied materials are quite uniform, the five-membered variants form monoclinic crystals and the pyridyl derivatives precipitate from the reaction mixture as rhombohedral crystals due to the zwitterionic structure, mentioned earlier (5.2).

As it was seen, cinnamic acids have a layered structure ${ }^{95}$ due to the combination of different hydrogen bonds as well as $\pi$-stacking interactions. To identify the $\pi$-stacking interactions powder $x$-ray diffractometry (XRD, 4.2.1) was applied. In the diffractograms, we looking for the signs of the layered structure (interlayer distances in the 350-500 pm range) belonging to $\pi-\pi$ bonding of the "sandwich" type among the heteroaromatic rings. (Figure 58 and Figure 59) display the results for the five-membered variants. It is seen that the furyl derivatives have intense reflections in the 15-20 $2 \theta^{\circ}$ region, thus, their structures are very similar, and assuming that these are first-order reflections, the calculated interlayer distances are within the range given above (Table 11).
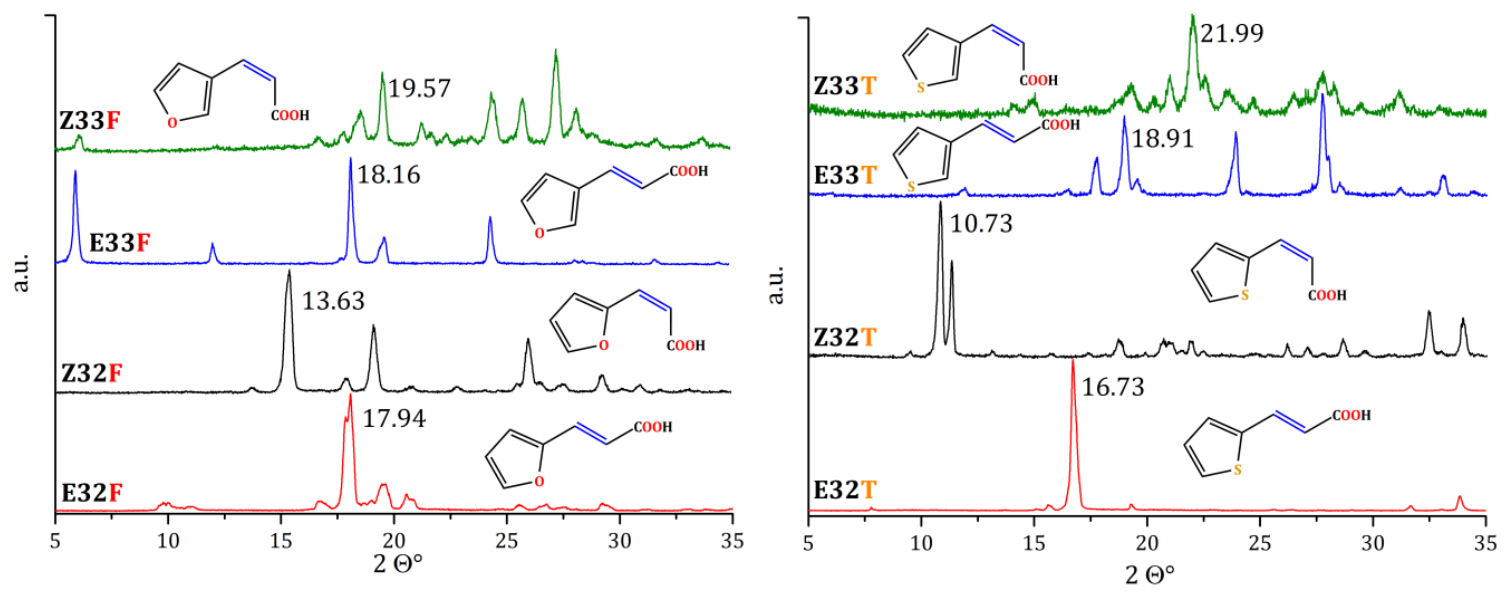

Figure 58 The powder X-ray diffractograms of the furyl-, and thienylcinnamic acids 

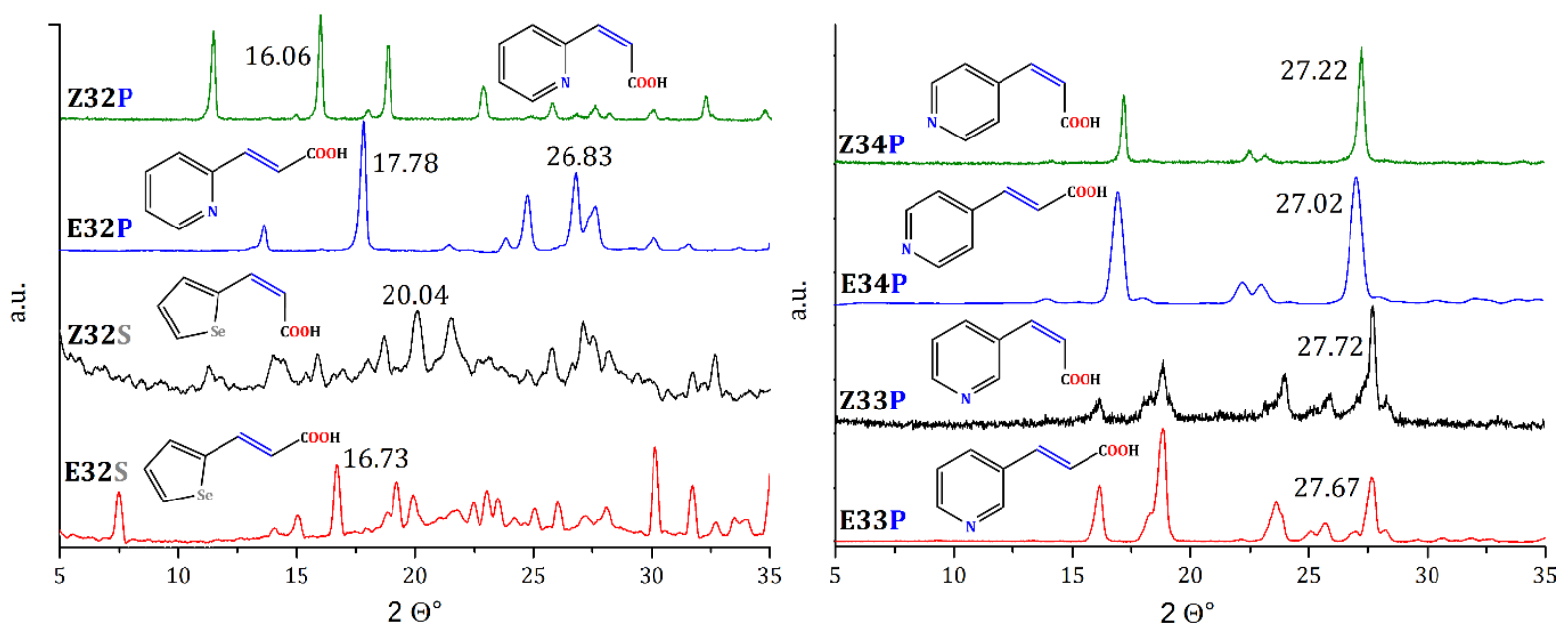

Figure 59 The powder X-ray diffractograms of the selenophenyl-, and pyridylcinnamic acids

The major interaction for the pyridyl derivatives in the solid state is the ionic bond among the zwitterions; therefore, these molecules do not have layered structure.
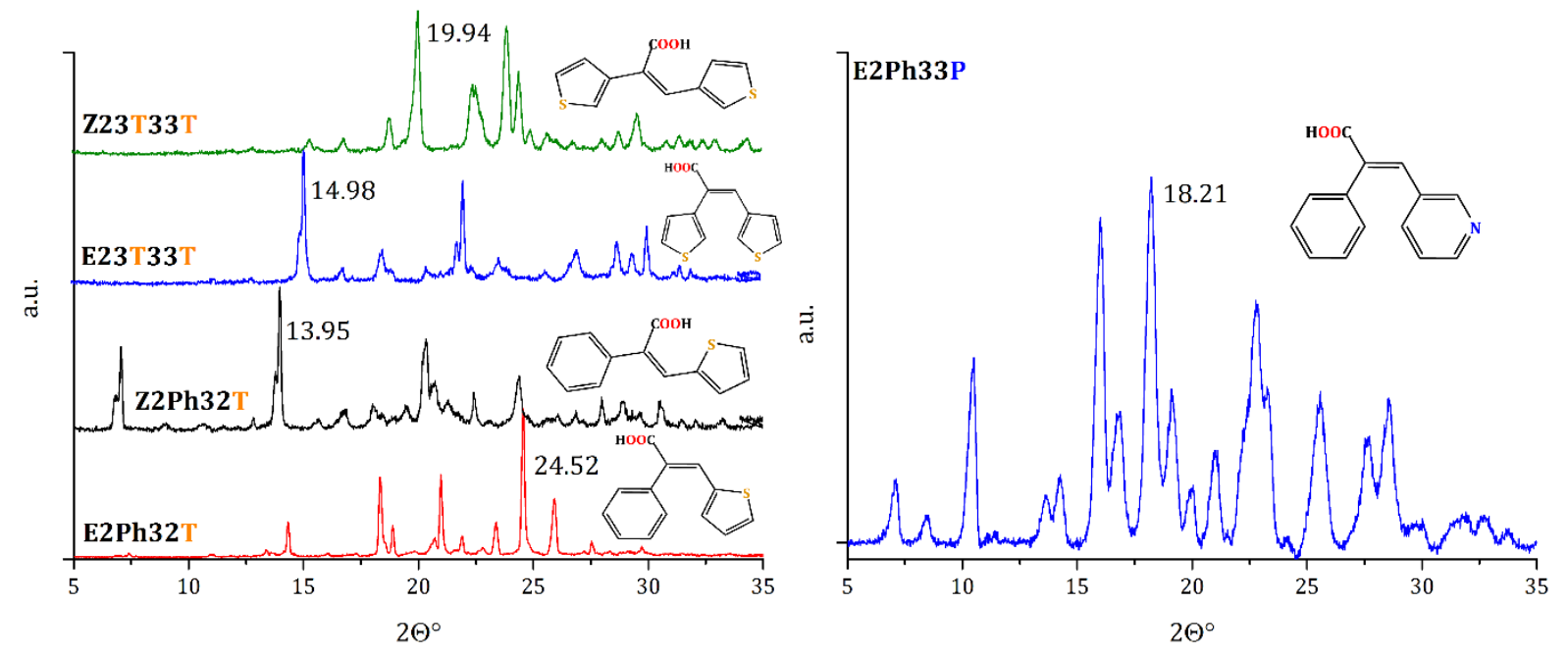

Figure 60 Powder X-ray diffractograms of some $\alpha$-substituted heteroaryl cinnamic acid derivatives

The $\alpha$-substituted derivatives have highly complicated X-ray diffractograms (Figure 60), and single crystal data are not available either; therefore, we decided not use the diffractograms for estimating the $\pi-\pi$ distances in the assumed but not proven $\pi-\pi$ close contacts.

For calculating the interlayer distances, the Bragg equation (Equation 1) was applied, and selected peak was treated as a first-order reflection $(n=1)$ (unfortunately, the determination if it is a first-order reflection indeed, is difficult from powder X-ray diffractograms; therefore these results are only used as guide for modelling): 


$$
n \lambda=2 d \sin \theta \quad \text { Equation } 1
$$

where $n$ is an integer, $\lambda$ is the wavelength of incident wave $(1.5418 \AA$ for the CuK $\alpha$ radiation), $d$ is the spacing between the planes in the lattice, and $\theta$ is the angle between the incident ray and the scattering planes. The calculated interlayer distances are listed in Table 11.

\begin{tabular}{cccc}
\hline Compound & Selected reflection $\left(\mathbf{2 \theta}^{\circ}\right)$ & $\mathbf{d}(\AA)$ & $\mathbf{d}(\mathbf{p m})$ \\
\hline E32F & 17.94 & 4.94 & 494 \\
Z32F & 13.63 & 6.49 & 649 \\
E33F & 18.16 & 4.88 & 488 \\
Z33F & 19.57 & 4.53 & 453 \\
E32T & 16.73 & 5.29 & 529 \\
Z32T & 10.76 & 8.21 & 821 \\
E33T & 18.91 & 4.69 & 469 \\
Z33T & 21.99 & 4.04 & 404 \\
E32S & 16.73 & 5.29 & 529 \\
Z32S & 20.04 & 4.43 & 443 \\
\hline
\end{tabular}

Table 11 Calculated interlayer distances for the five-membered variants

\subsection{Self-assembling of the studied molecules over polycrystalline gold and silver surfaces}

The self-assembling capabilities were studied over $100 \mathrm{~nm}$ thick polycrystalline gold and silver surfaces created by the PLD technique (4.1.3). Before depositing the organic matter, the metal layers were checked by scanning electron microscopy (SEM, 4.2.2) to gain some information about the morphology of the surface. The results are shown in Figure 61. 

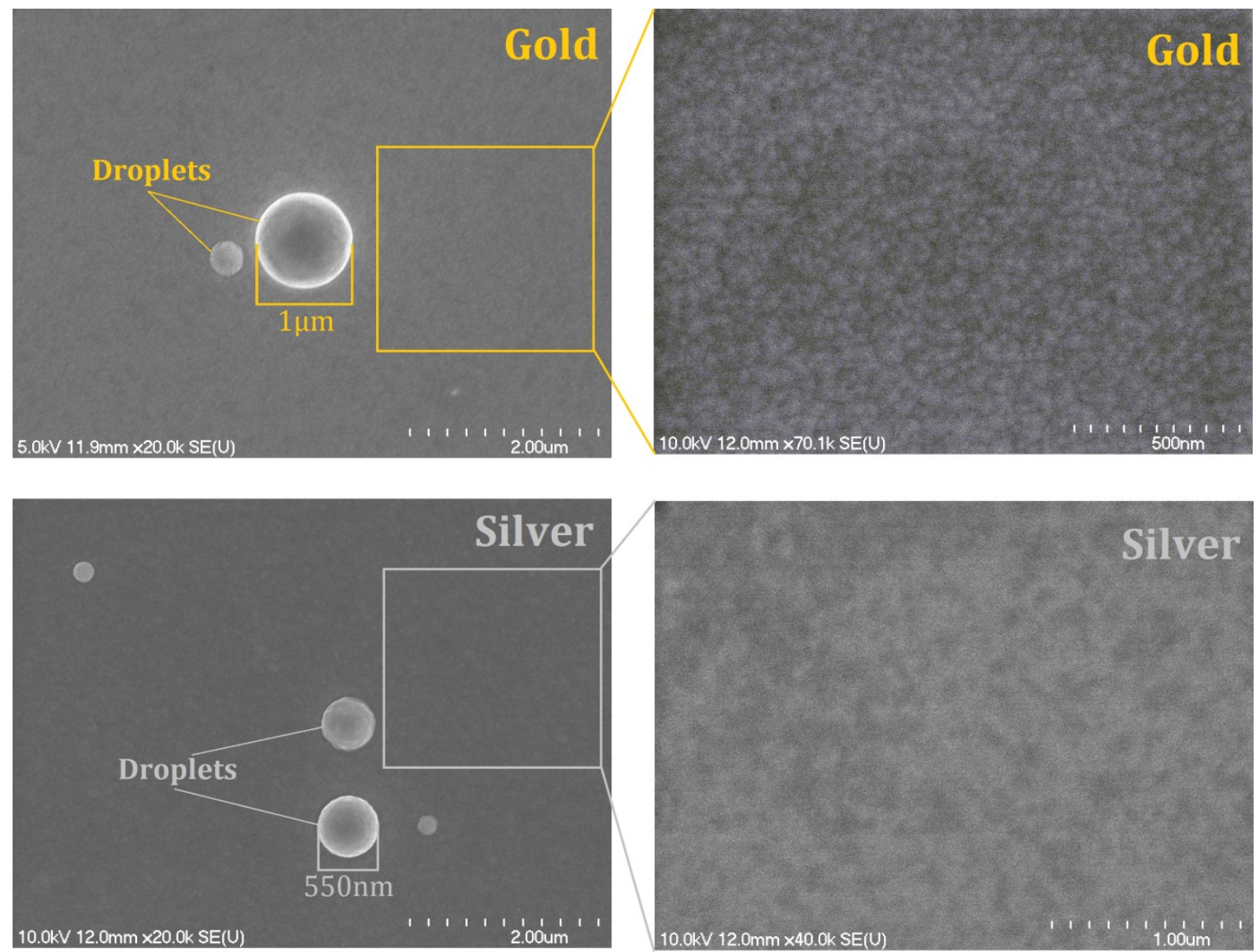

Figure 61 SEM images of the pristine gold and silver layers made by the PLD technique

As we can see, the layers are enfolded with differently sized droplets of 50-1000 $\mathrm{nm}$ (the average size of the droplets is $500 \mathrm{~nm}$, determined by size distribution analysis); however, the spaces between these objects are smooth; therefore, the topology of the assembled structures of the deposited molecules are possible to study by atomic force microscopy (AFM, 4.2.2) with relatively high precision ( $\pm 2 \mathrm{~nm}$ deviation).

The metal layers were treaded with the $0.1 \mathrm{M}$ solution in chloroform of the studied isomers, in the way mentioned earlier (4.1.3), and the presence of the deposited molecules were checked by infrared microspectroscopy (IRM, 4.2.2). Due to the low concentration of the molecules on the metal surface, the main and very intense vibrations could only be identified beside the huge vibrations and rotations of the atmospheric components like water and $\mathrm{CO}_{2}$ (marked on the spectra). Since all other bands were barely higher than the noise level, the spectra were only used for checking the success of the deposition Thus, IRM spectra corresponding to one molecule is shown (Figure 62). 

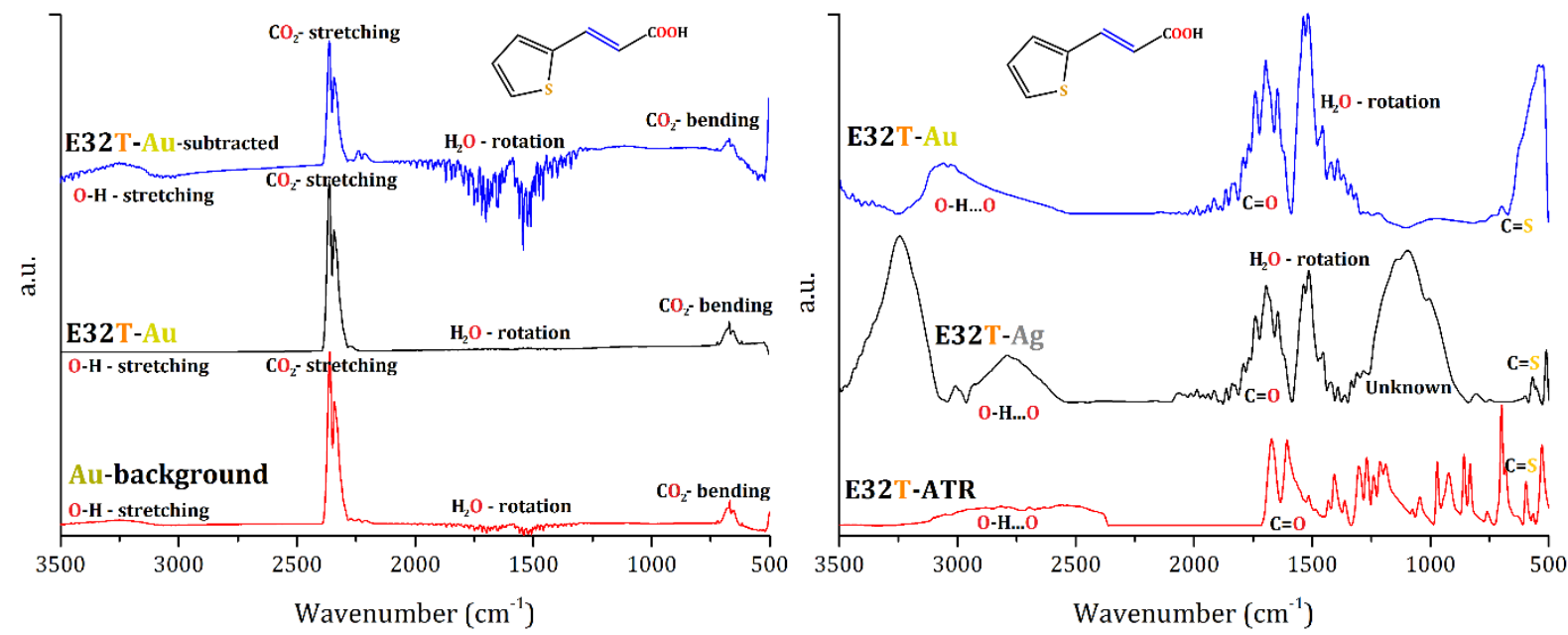

Figure 62 Deposition of the E32T molecules on gold and silver surfaces followed by IRM

A few vibrations definitely corresponding to the organic material can be assigned like the $\mathrm{C}=\mathrm{S}$ vibrations at $600 \mathrm{~cm}^{-1}$ (cannot identified unambiguously in all cases due to the $\mathrm{C}=\mathrm{O}$ bending), the $\mathrm{C}=0$ stretching at $1600 \mathrm{~cm}^{-1}$ and the wide $\mathrm{O}-\mathrm{H} \ldots \mathrm{O}$ stretching around $3000 \mathrm{~cm}^{-1}$, which means that the dimers are still kept together via $\mathrm{O}-\mathrm{H} \ldots \mathrm{O}=\mathrm{C}$ hydrogen bond, i.e., the structure of the absorbed layer may close resemble that of the crystalline state.

After being ascertained about the success of the deposition, the adsorbed layers were studied by AFM. The AFM images of the two different metal surfaces were recorded first. Then, the metal surfaces were treated with the octylesters of the two $E$ thienyl isomers, E32T0 and E33T0. (Due to the steric hindrance between the alkyl chain and the thiophene ring, the orientation of the Z-thienylcinnamic acid octylesters cannot be studied this way; nevertheless, because of the structural similarities, the fashion of orientation should be the same as of the $E$ isomers. The aim of this investigation was to determine the orientation of the molecules to the surface. The sulfur in the thienyl group has significantly more affinity to adsorb on the gold and silver surfaces than either the ester group or the alkyl chain. Thus, the resulting layer thickness is very small (1-2 nm) if the molecules adsorb parallel to the surface, and becomes relatively large if they do it in a perpendicular fashion. Figure 63 shows the results of the orientation experiments on the example of E32T0 molecules. 

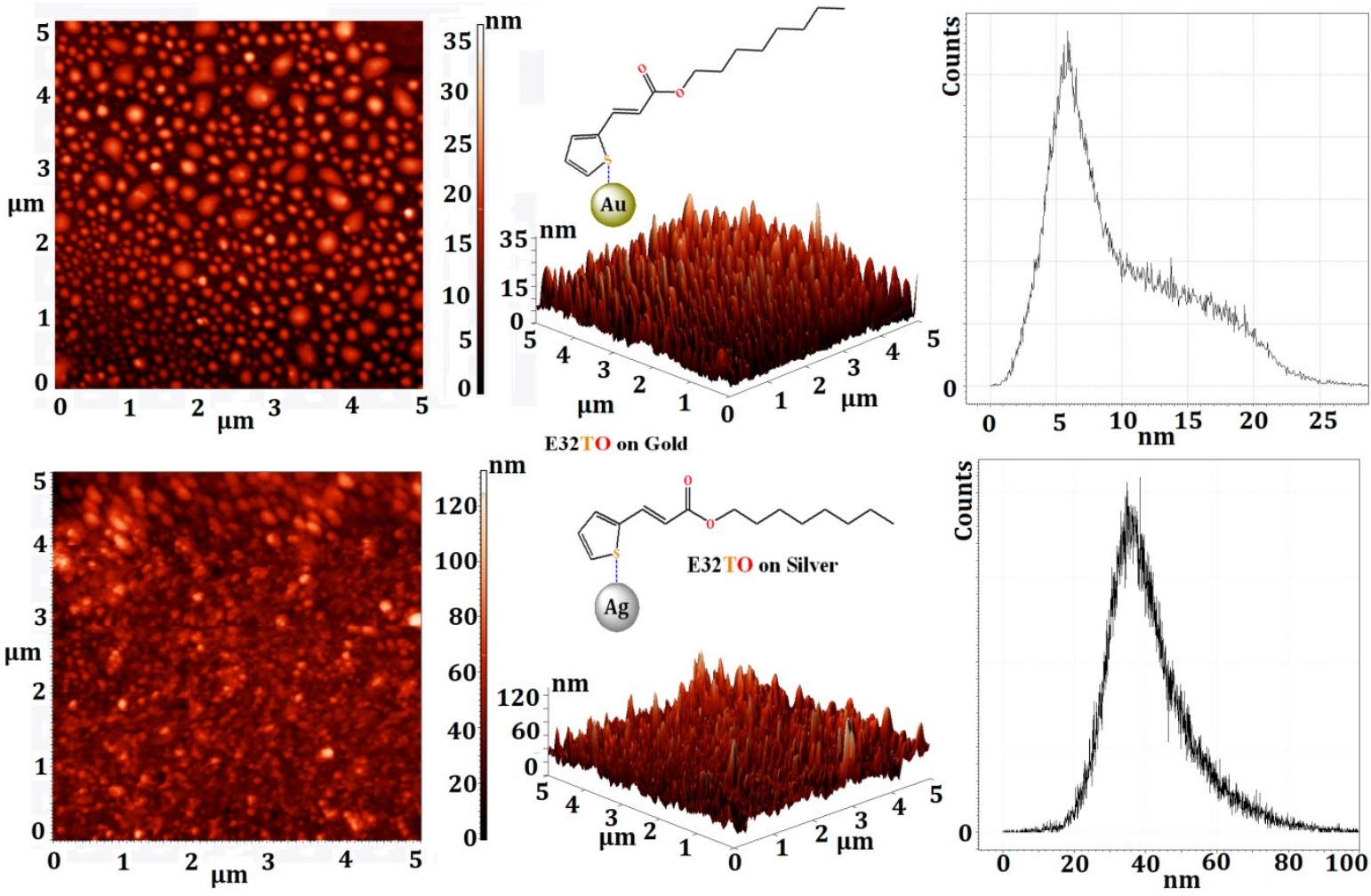

Figure 63 The AFM result of the orientation experiment on both gold and silver surfaces

It is seen that the coverage is homogenous over both surfaces; however, the thickness of the adsorbed layers differs from each other. Over the gold surface, it is close to a single monomolecular carpet; thus, the orientation should be nearly perpendicular. The opposite was found for the silver surface, where the adsorbed layer is quite thick, which is a sign of a multilayer formation, which requires nearly parallel orientation of the molecules to the silver surface. Similar results were obtained for the E33T0 isomer over both surfaces.

Three types of general examples were identified for the different formation types of the studied molecules over polycrystalline gold and silver surfaces. They are displayed in Figure 64.

Type 1: The adsorption of the E32F molecule over the gold surface leads to homogenous coverage and close to uniform layer thickness. This is the most frequent situation, where the average height of the peaks is $10-38 \mathrm{~nm}$ and the average space between them is 30-38 nm (E32F-Ag, E33T-Ag, E33F-Ag). The topology of E34P on silver is common as well, with heavy organization and lower homogeneity: average high of peaks is 25-45 nm with 100nm inter-peak distance (E33P-Au, E32P-Ag, E32P-Au, 
E33F-Au). There are examples (E33T-Au, E32T-Au), when the number of adsorbed layers is very low (maximum height of peaks is $4 \mathrm{~nm}$ ), but the coverage is nearly complete (peak to peak distance is $<10 \mathrm{~nm}$ ).

Type 2: Two examples are shown for higher-order organization: Z22T32T on gold and Z23P3Ph on silver surface, where the average high of peaks is $25-85 \mathrm{~nm}$ and the interpeak distance is $100 \mathrm{~nm}$.

Type 3: The last examples are not follow the self-assembling phenomena, because the formations are derived by surface defects like metal droplets. We can see two different cases; where the molecules are deposited on a "huge" $(2 \times 2 \times 1 \mu \mathrm{m})$ metal droplet (Z23T3Ph-Au) and the curvature is facilitate the organization. In the other case, where the Z22T32T molecules are organized around a "small" (100 × $100 \times 50 \mathrm{~nm})$ droplet in a concentric circular fashion $(d=9 \mu \mathrm{m})$, governed by the surface defect. 

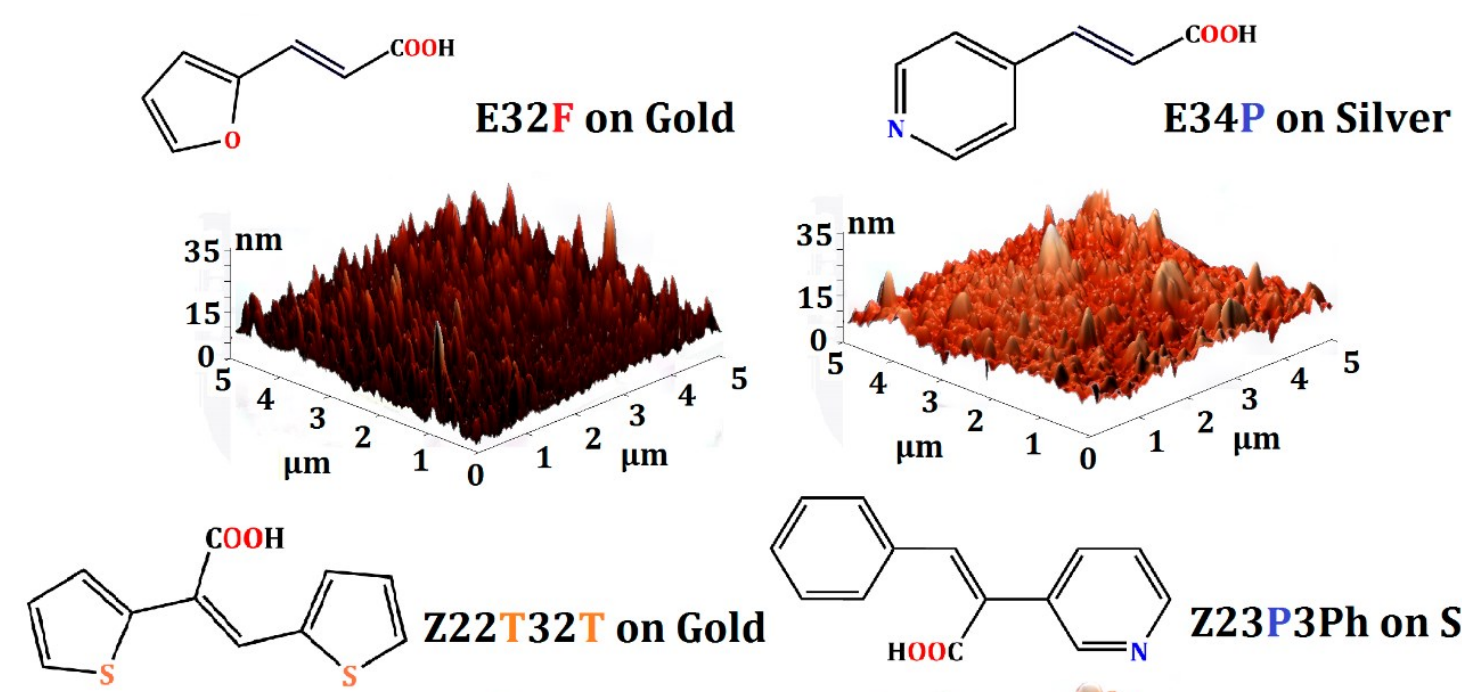

\section{Z22T32T on Gold}
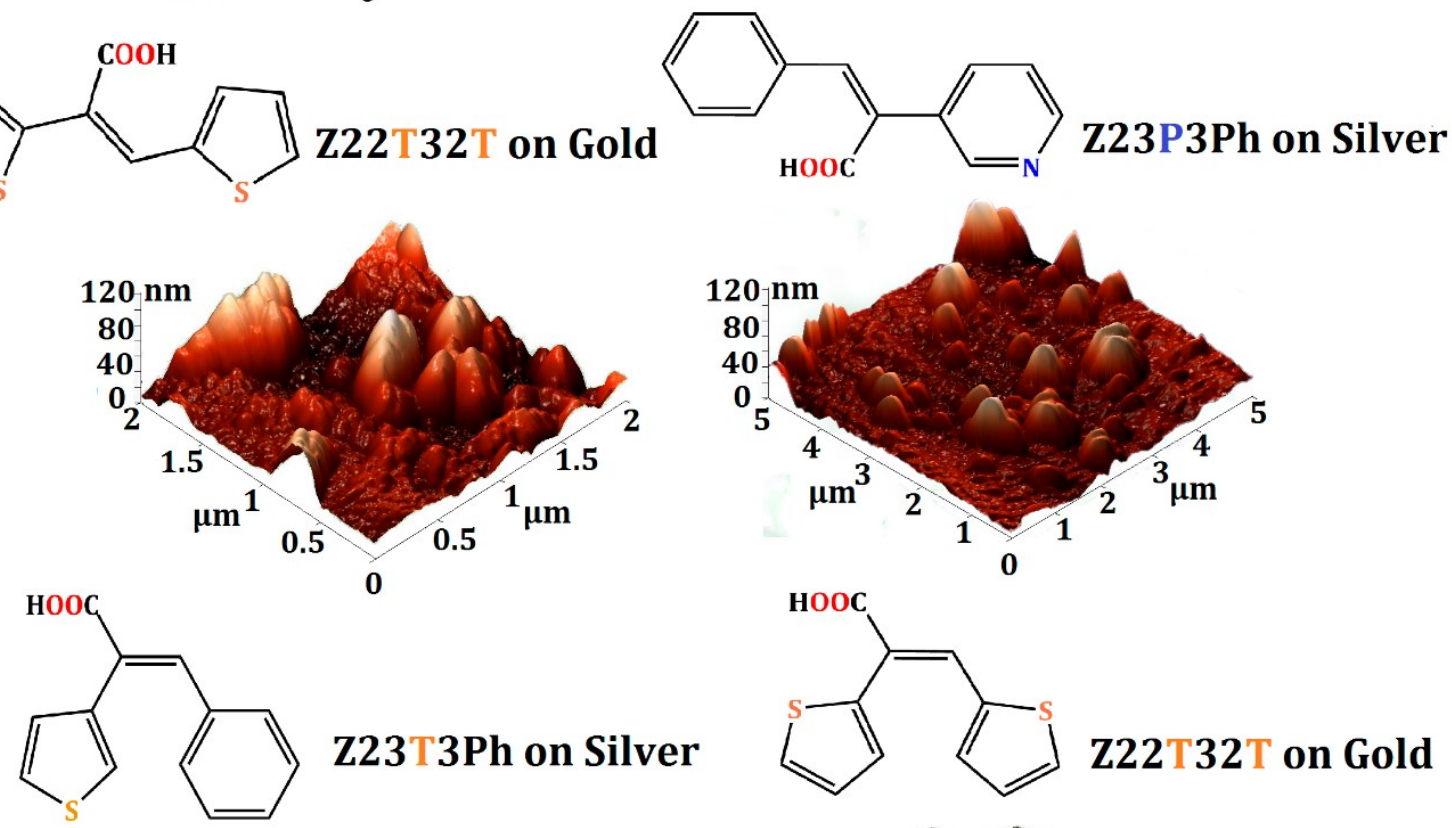

\section{Z23T3Ph on Silver}
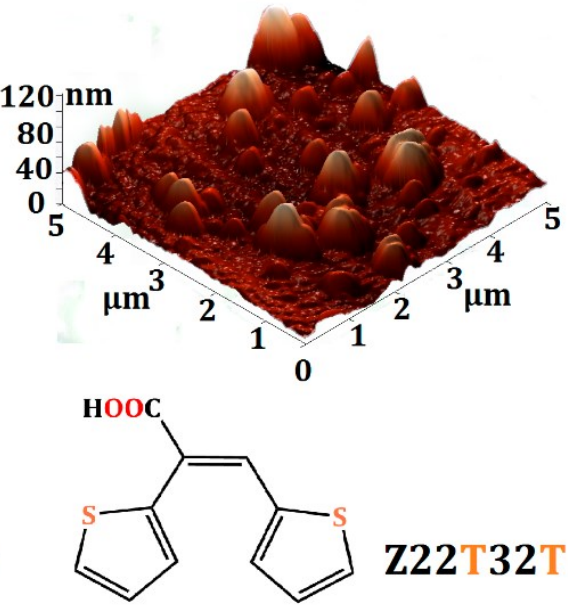

Z22T32T on Gold
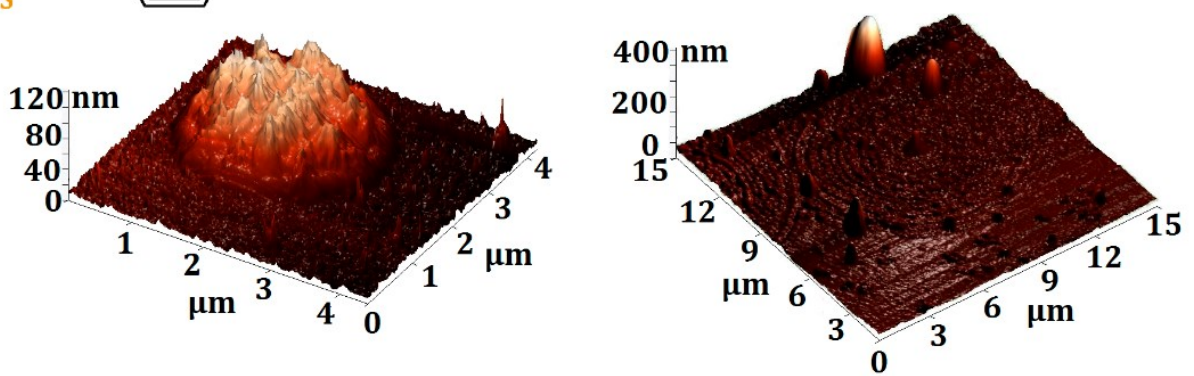

Figure 64 Selected 3D AFM images of the studied materials on both gold and silver surfaces: type 1 :

E32F-Au, E34P-Ag; type 2: Z22T32T-Au, Z23P3Ph-Ag; type 3: Z23T3Ph-Ag, Z22T32T-Au

Based on literature data and our own measurements, we propose that the mechanism of the self-assembling is the following: The first step is the covalent adsorption on the metal surface of the dimers (for the five-membered derivatives) or the monomers (in the case for the pyridyl compounds) via the heteroatom of the aromatic ring. Then, when the surface is saturated with the adsorbed species, the molecular assemblies start to grow, and the components are kept together with weaker interactions, like weak (aromatic)C-H...S(N) hydrogen bonds and $\pi$-stacking interactions. 
Due to surface defects, the studied derivatives form multimolecular carpets with different thicknesses, and the assembled molecules stand nearly perpendicular to the surface. The size of the aggregates found on the metal surfaces were varied; however, the estimated number of the molecules in the layer was always more than a single dimer; consequently, it is safe to state that the weak (aromatic)C-H...S(N) hydrogen bonds and $\pi$-stacking interactions play dominant role in the formation of self-assembled structures over these metal surfaces. The schematic representation of the resulting structure is given in Figure 65.

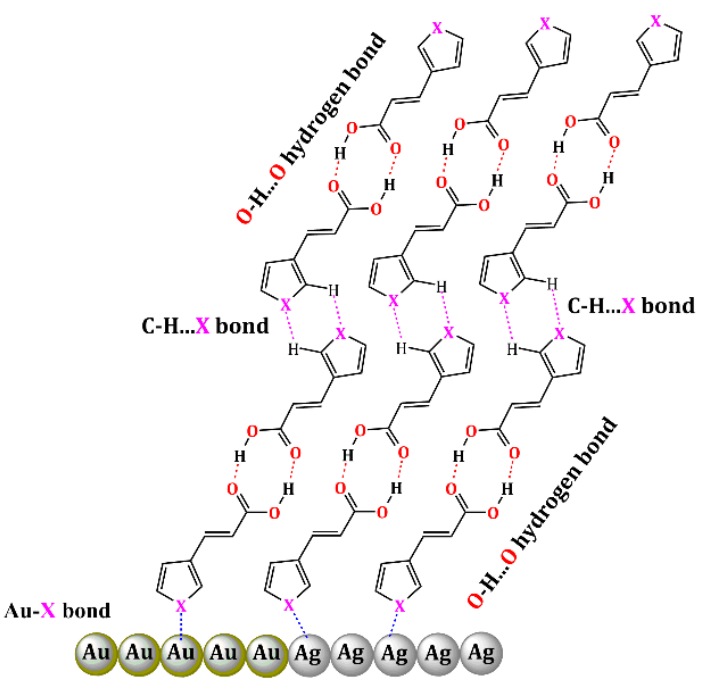

Figure 65 The schematic reperesentation of the self-assembled multilayer over Ag and Au surfaces

\subsection{Computational results}

\subsubsection{Conformational analysis}

For the conformational study the "random walk" algorithm was chosen, because it covers the potential energy surface well with significantly less calculated points. An example for the results of a conformational analysis is represented with E32P (performed at HF/6-31G(d,p) level with Gaussian 09' and processed with Izzy Reader v.1.0) is shown in Figure 66. The structure of the potential surface is quite typical for cinnamic acid derivatives. The structure with the lowest energy, designated as " $\mathrm{A}$ ", is located in a potential energy pit in the middle of the potential energy surface. Here, both pyridyl and carboxyl dihedrals are $0^{\circ}$, which means completely flat molecular structure. The other minima on the surface are marked as "B", "C" and "D". They represent the four other possible conformers. This was the situation for all the molecules studied. The heights of the rotation barriers dividing the minima are in the $3-9 \mathrm{kcal} / \mathrm{mol}$ range for 
the E32P isomer. Another interesting observation is the anomalously high potential barrier at $-90^{\circ}$. This is a sign of intramolecular hydrogen bonds; however, the molecule can rotate through lower barriers to reach other conformations. Due to the relatively low rotation barriers, one can predict close to free rotation for all rotatable part of the molecules, completely coinciding with the results of the NOESY experiments.
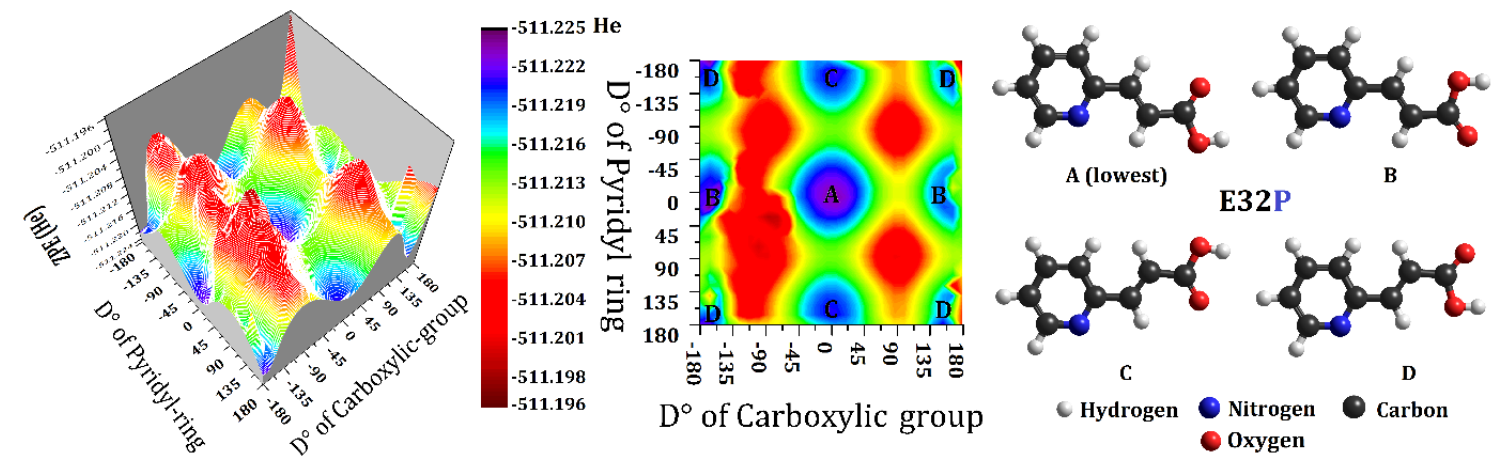

Figure 66 The calculated potetntial energy surface of E32P isomer and the resulted four conformers

The potential energy surfaces of the $\alpha$-substituted heteroaryl cinnamic acids are not shown here, because they have three dihedral angles, thus, the potential energy surfaces cannot be represented in 3D diagrams.

The most stable conformers resulting from the conformational analysis of all studied molecules are depicted in Figure 67. As has been mentioned already, they are all flat except the zwitterionic forms, where the carboxylate group turns out of the plane with $48-117^{\circ}$. The $\mathbf{Z 3 2 P - Z W}$ derivative has completely twisted structure due to the close contact of the differently charged parts of the molecule. 


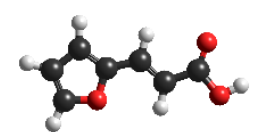

E32F

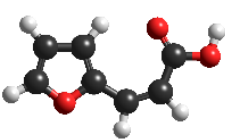

Z32F

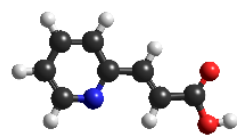

E32P

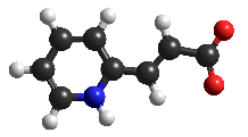

E32P-ZW

c Hydrogen

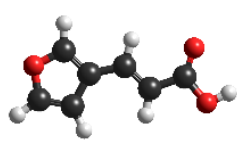

E33F

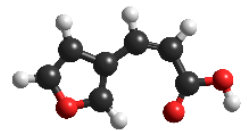

Z33F
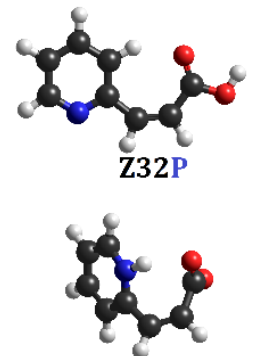

Z32P-ZW

- Carbon

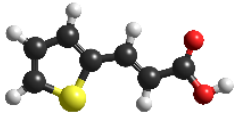

E32T

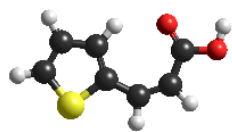

Z32T

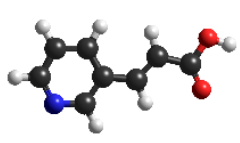

E33P

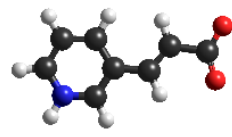

E33P-zW

- Nitrogen

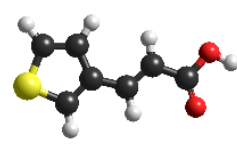

E33T

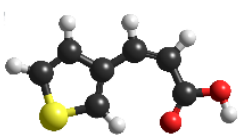

Z33T

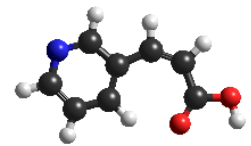

Z33P

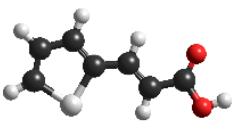

E32S

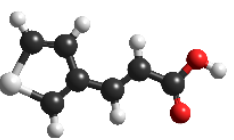

E33S

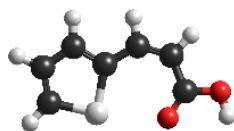

Z32S

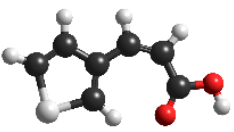

Z33S

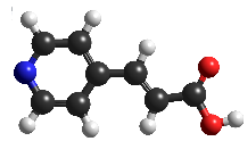

E34P

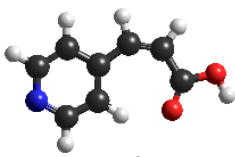

Z34P

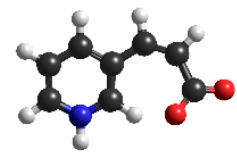

Z33P-ZW

- Oxygen

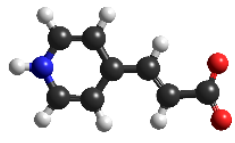

E34P-ZW

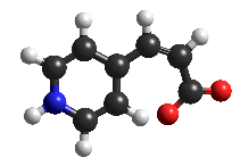

Z34P-ZW

C Sulphur C Selenium

Figure 67 The most stable conformers of the studied molecules calculatd at HF/6-31G(d,p) level

The resulting structures from the conformational analysis are used as the starting geometries for the higher level calculations (B3LYP/CBSB7, B3LYP/6-31++G(d,p), WB97XD/CBSB7, WB97XD/6-31++G(d,p)), and the thermally corrected (to 298K) zero-point energies (ZPE) and the energy difference between the stereoisomers are listed in Table 12 for several different DFT methods and basis sets. It is seen that the $E$ isomer is the thermodynamically more stable state in each case, as it was indicated by the experimental results in the synthetic part 4.3.2.

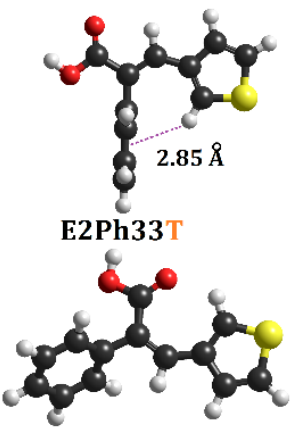

Z2Ph33T

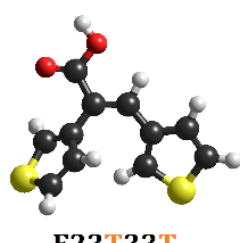

E23T33T

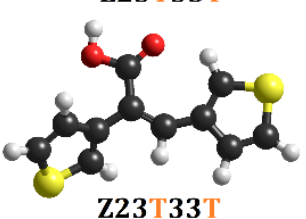

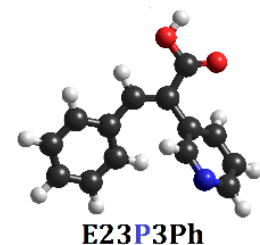

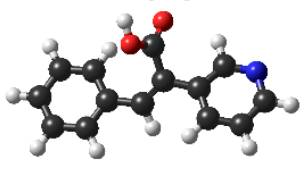

Z23P3Ph
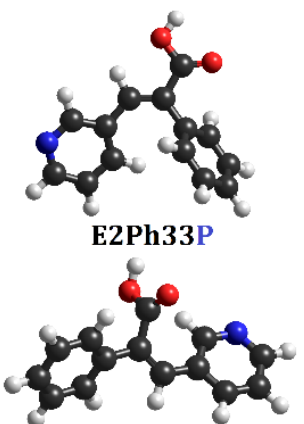

Z2Ph33P
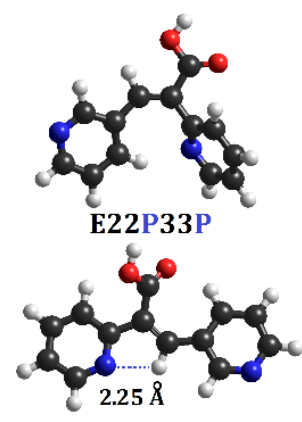

Z22P33P

Figure 68 The most stable conformers of the selected $\alpha$-substituted derivatives, calculated at the PM6 level 


\begin{tabular}{|c|c|c|c|c|c|c|c|c|}
\hline $\begin{array}{c}\text { Compou } \\
\text { nd }\end{array}$ & $\begin{array}{c}\text { B3LYP/CBSB7 } \\
\text { ZPE }_{\text {corr }} \text { (He) }\end{array}$ & $\begin{array}{c}E-Z \\
\text { difference } \\
\text { (kcal/mol) }\end{array}$ & $\begin{array}{c}\text { B3LYP/6- } \\
\text { 31++G(d,p) ZPE } \\
\text { (He) }\end{array}$ & $\begin{array}{c}E-Z \\
\text { difference } \\
(\text { kcal/mol) }\end{array}$ & $\begin{array}{c}\text { WB97XD/CBSB } \\
7 \mathrm{ZPE}_{\text {corr }}(\mathrm{He})\end{array}$ & $\begin{array}{c}E-Z \text { difference } \\
\text { (kcal/mol) }\end{array}$ & $\begin{array}{l}\text { WB97XD/6- } \\
31++G(d, p) \\
\text { ZPE }_{\text {corr }}(\mathrm{He}) \\
\end{array}$ & $\begin{array}{c}E-Z \\
\text { difference } \\
\text { (kcal/mol) }\end{array}$ \\
\hline E32F & -496.144524 & \multirow{2}{*}{-2.72} & -496.042186 & \multirow{2}{*}{-2.76} & -495.971373 & \multirow{2}{*}{-2.55} & -495.8724561 & \multirow{2}{*}{-2.55} \\
\hline Z32F & -496.140191 & & -496.037791 & & -495.967297 & & -495.8683909 & \\
\hline E33F & -496.138857 & \multirow{2}{*}{-2.44} & -496.036746 & \multirow{2}{*}{-2.66} & -495.967292 & \multirow{2}{*}{-2.27} & -495.8684852 & \multirow{2}{*}{-2.40} \\
\hline Z33F & -496.134967 & & -496.032507 & & -495.963674 & & -495.8646622 & \\
\hline E32T & -819.129919 & \multirow{2}{*}{-3.44} & -819.017331 & \multirow{2}{*}{-3.90} & -818.961618 & \multirow{2}{*}{-3.47} & -818.8521323 & \multirow{2}{*}{-3.87} \\
\hline Z32T & -819.124437 & & -819.011110 & & -818.956088 & & -818.8459634 & \\
\hline E33T & -819.128781 & \multirow{2}{*}{-3.05} & -819.016004 & \multirow{2}{*}{-3.37} & -818.961627 & \multirow{2}{*}{-2.96} & -818.8519007 & \multirow{2}{*}{-3.22} \\
\hline Z33T & -819.123927 & & -819.010630 & & -818.956905 & & -818.8467706 & \\
\hline E32S & -2822.451564 & \multirow{2}{*}{-1.34} & -2820.237288 & \multirow{2}{*}{-1.69} & -2822.327049 & \multirow{2}{*}{-1.50} & -2820.10881 & \multirow{2}{*}{-1.78} \\
\hline Z32S & -2822.449432 & & -2820.234588 & & -2822.324650 & & -2820.105973 & \\
\hline E33S & -2822.449507 & \multirow{2}{*}{-3.40} & -2820.234428 & \multirow{2}{*}{-2.87} & -2822.326252 & \multirow{2}{*}{-3.30} & -2820.10706 & \multirow{2}{*}{-2.71} \\
\hline Z33S & -2822.444087 & & -2820.229859 & & -2822.320979 & & -2820.102741 & \\
\hline E32P & -514.402659 & \multirow{2}{*}{-4.69} & -514.301571 & \multirow{2}{*}{-4.78} & -514.219814 & \multirow{2}{*}{-4.73} & -514.1223717 & \multirow{2}{*}{-4.77} \\
\hline Z32P & -514.395185 & & -514.293951 & & -514.212263 & & -514.1147685 & \\
\hline E33P & -514.399025 & \multirow{2}{*}{-3.48} & -514.298383 & \multirow{2}{*}{-3.66} & -514.216424 & \multirow{2}{*}{-3.59} & -514.1191916 & \multirow{2}{*}{-3.70} \\
\hline Z33P & -514.393472 & & -514.292549 & & -514.210690 & & -514.1132911 & \\
\hline E34P & -514.398239 & \multirow{2}{*}{-4.46} & -514.297655 & \multirow{2}{*}{-4.65} & -514.215743 & \multirow{2}{*}{-4.59} & -514.11862 & -476 \\
\hline Z34P & -514.391136 & & -514.290245 & & -514.208416 & & -514.1110311 & \\
\hline
\end{tabular}

Table 12 Energy results for the optimized monomers of heteroaryl cinnamic acids using several different basis sets and functional combinations 


\begin{tabular}{ccc}
\hline $\begin{array}{r}\text { Thermally corrected (to 298K) zero-point energies (ZPEcorr) from geometry optimization } \\
\text { checked with frequency calculations for the monomers of } \boldsymbol{\alpha} \text {-substituted heteroaryl cinnamic } \\
\text { acids, using the lowest structure from conformational analysis as the input. }\end{array}$ \\
\hline Compound & B3LYP/CBSB7 ZPEcorr (He) & E-Z difference (kcal/mol) \\
\hline E2Ph33T & -1050.230284 & -2.70 \\
Z2Ph33T & -1050.225975 & \\
E23T33T & -1370.993100 & \\
Z23T33T & -1370.996034 & -3.94 \\
E23P3Ph & -745.500469 & \\
Z23P3Ph & -745.494178 & -0.36 \\
E22P33P & -761.539032 & \\
Z22P33P & -761.538447 & -3.84 \\
E2Ph33P & -745.499894 & \\
Z2Ph33P & -745.493772 & \\
\hline
\end{tabular}

Table 13 Energy results for the optimized monomers of $\alpha$-substituted cinnamic acids at B3LYP/CBSB7 level

The geometry and energy data derived from the conformational analysis of the $\alpha$ substituted derivatives are shown in Figure 68 and Table 13. The results differ from the unsubstituted heteroaryl cinnamic acids, because none of them have planar structures due to the steric hindrance among the bulky groups on the olefinic skeleton. In some cases intramolecular interactions could be identified, e.g. a $\mathrm{C}-\mathrm{H}$...N bond $(2.25 \AA)$ in Z22P33P or a C-H...T interaction (2.85 Å) in E2Ph33T. Another important observation is the energy difference between the stereoisomers, where the energies are close to zero or even have positive value, which means among the $\alpha$-substituted derivatives, occasionally, the $Z$ isomer is the thermodynamically more stable form in some cases. This finding correlates well with the experimental observations, e.g. with the isomer distribution in the modified Perkin condensation.

\subsubsection{Hydrogen-bonded dimers}

As we have seen already, the fundamental unit of the self-assembled structures is the cyclic double hydrogen-bonded dimers kept together with strong $\mathrm{O}-\mathrm{H}$...O hydrogen bonds between the carboxylic groups. These dimers were constructed from the optimized monomers for further calculations. Some examples for the hydrogen-bonded dimers are shown in Figure 69. The other derivatives looks completely similar: the dimeric forms of each heteroaryl cinnamic acid derivative, both $E$ and $Z$ isomers have completely planar structure as it is indicated in Table 14. The table shows the energy and geometry data for the hydrogen-bonded dimers calculated using two different basis 
sets with the B3LYP functional (B3LYP/CBSB7 and B3LYP/6-31++G(d,p)). The bond lengths of the cyclic hydrogen bonds are quite regular for each derivative: $1.67 \pm 0.02 \AA$ with the CBSB7 basis set and $1.64 \pm 0.02 \AA$ with the $6-31++G(d, p)$. The bonding energies look similar as well, and they are independent from the type of the heterocycle. However, there are significant differences between the $E$ and $Z$ isomers; the bonding energy is 1 $\mathrm{kcal} / \mathrm{mol}$ smaller than that in the $E$ dimers. The average bonding energy is $14.6 \pm 0.7$

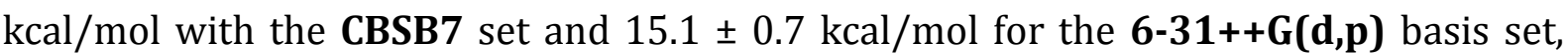
which correlate well with the experimental data for the dissociation energy of carboxylic acids.

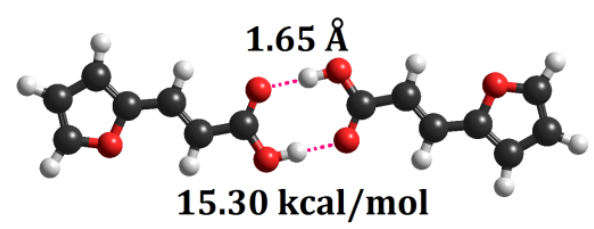

E32FD

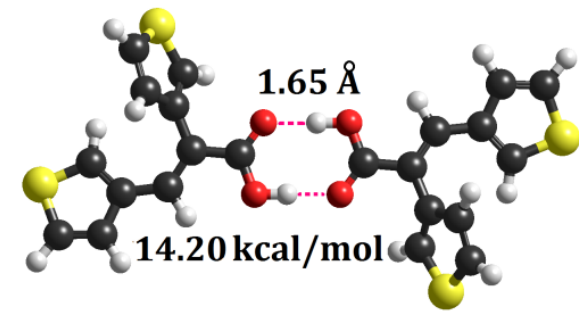

E23T33TD

Figure 69 Structures, hydrogen bond length and energy data for two hydrogen-bonded dimers (E32FD and E23T33TD) calculated at B3LYP/CBSB7 level

The ZPE of the dimers are BSSE corrected, and the bonding energies of the hydrogen bonds are calculated using the following formula (it produces positive bonding energy value if it is favorable and negative if it is not):

$$
E_{H-\text { bond }}=\left(2 * Z P E_{\text {monomer }}\right)-Z P E_{\text {dimer }\left(B S S E_{\text {corrected }}\right)} \quad \text { Equation } 2
$$

The $\alpha$-substituted derivatives form more interesting structures, and their geometries are different from those of the corresponding monomers. In Figure 70 one can see the effect of steric hindrance among the aromatic rings, which makes the shape of the 0 $\mathrm{H} . . . \mathrm{O}=\mathrm{C}$ vibrations different in the infrared spectrum. 


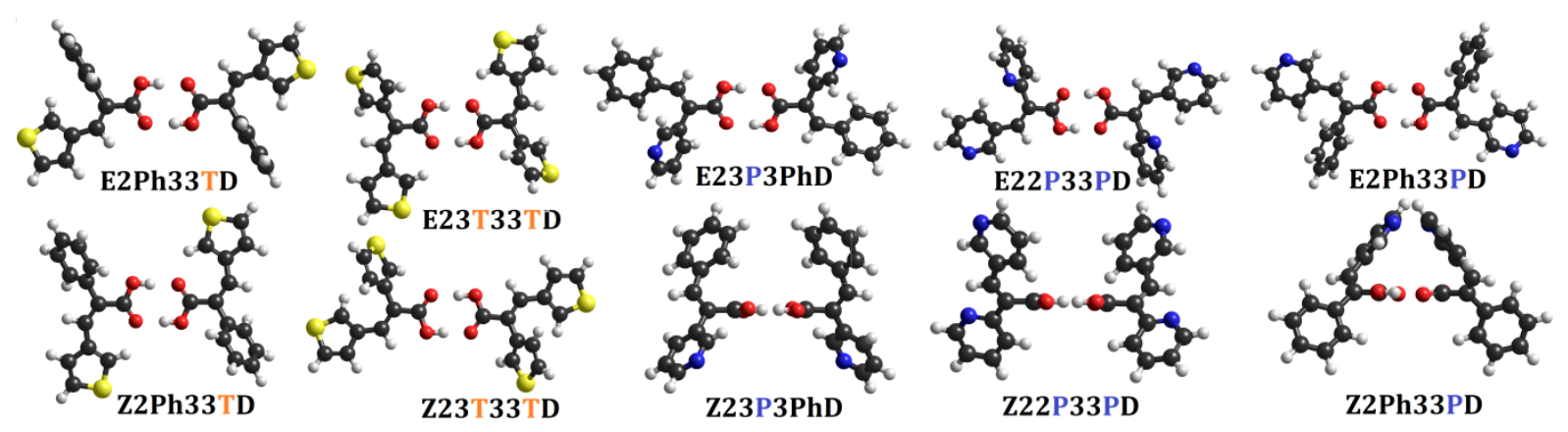

Figure 70 The optimized structures of some $\alpha$-substituted heteroaryl cinnamic acid derivative calculated at B3LYP/CBSB7 level 


\begin{tabular}{|c|c|c|c|c|c|c|c|c|c|c|}
\hline \multicolumn{11}{|c|}{$\begin{array}{l}\text { Thermally (to } 298 \mathrm{~K}) \text { and BSSE corrected zero-point energies }(\mathrm{ZPE} \text { corr) from geometry optimization checked with frequency calculations for the } \\
\text { hydrogen-bonded dimers }(0-\mathrm{H} \ldots \mathrm{O}=\mathrm{C}) \text { using the optimized monomers as the input. }\end{array}$} \\
\hline Compound & $\begin{array}{l}\text { B3LYP/CBSB7 } \\
\text { ZPEcorr (He) }\end{array}$ & $\begin{array}{l}\text { H-bond } \\
\text { Ecorr }\end{array}$ & $\begin{array}{l}\text { BSSEcorr } \\
\text { (kcal/mol) }\end{array}$ & $\begin{array}{l}\text { H-bond } \\
\text { length }(\AA)\end{array}$ & $\mathbf{D}^{\circ}$ & $\begin{array}{c}\text { B3LYP/6- } \\
\text { 31++G(d,p) ZPE } \\
\text { (He) }\end{array}$ & $\begin{array}{l}\text { H-bond } \\
\text { Ecorr }\end{array}$ & $\begin{array}{c}\text { BSSE }_{\text {corr }} \\
\text { (kcal/mol) }\end{array}$ & $\begin{array}{c}\text { H-bond } \\
\text { length }(\AA)\end{array}$ & $\mathbf{D}^{\circ}$ \\
\hline E32FD & -992.313422 & 15.30 & 3.43 & 1.65 & 0.1 & -992.1096493 & 15.86 & 0.83 & 1.64 & 0.10 \\
\hline Z32FD & -992.302794 & 14.06 & 3.17 & 1.68 & 0.7 & -992.0989242 & 14.65 & 0.97 & 1.65 & 0.80 \\
\hline E33FD & -992.302200 & 15.37 & 3.40 & 1.65 & 0.0 & -992.0988963 & 15.94 & 0.82 & 1.63 & 0.10 \\
\hline Z33FD & -992.292002 & 13.85 & 3.15 & 1.68 & 0.0 & -992.0879833 & 14.41 & 1.00 & 1.65 & 0.00 \\
\hline E32TD & -1638.284314 & 15.36 & 3.39 & 1.65 & 0.9 & -1638.060023 & 15.91 & 0.84 & 1.63 & 0.00 \\
\hline Z32TD & -1638.271129 & 13.96 & 3.14 & 1.68 & 0.0 & -1638.045377 & 14.53 & 0.97 & 1.65 & 0.00 \\
\hline E33TD & -1638.282083 & 15.39 & 3.39 & 1.65 & 0.0 & -1638.057438 & 15.96 & 0.80 & 1.63 & 0.10 \\
\hline Z33TD & -1638.269825 & 13.79 & 3.13 & 1.68 & 0.3 & -1638.044095 & 14.33 & 0.96 & 1.66 & 0.40 \\
\hline E32SD & -5644.927597 & 15.35 & 3.38 & 1.65 & 0.0 & -5640.499972 & 15.94 & 1.36 & 1.62 & 0.00 \\
\hline Z32SD & -5644.921462 & 14.18 & 3.17 & 1.68 & 0.0 & -5640.492421 & 14.59 & 2.62 & 1.64 & 0.00 \\
\hline E33SD & -5644.923500 & 15.37 & 3.38 & 1.65 & 0.4 & -5640.494238 & 15.93 & 0.87 & 1.63 & 0.00 \\
\hline Z33SD & -5644.910203 & 13.82 & 3.12 & 1.68 & 0.0 & -5640.482558 & 14.33 & 1.97 & 1.65 & 0.00 \\
\hline E32PD & -1028.829406 & 15.12 & 3.40 & 1.66 & 0.6 & -1028.628092 & 15.66 & 0.87 & 1.65 & 0.00 \\
\hline Z32PD & -1028.812458 & 13.86 & 3.09 & 1.68 & 0.8 & -1028.61082 & 14.38 & 0.97 & 1.66 & 0.60 \\
\hline E33PD & -1028.822748 & 15.50 & 3.30 & 1.65 & 0.0 & -1028.622334 & 16.05 & 0.84 & 1.65 & 0.00 \\
\hline Z33PD & -1028.809013 & 13.85 & 3.07 & 1.68 & 0.0 & -1028.608003 & 14.37 & 0.96 & 1.66 & 0.00 \\
\hline E34PD & -1028.821017 & 15.40 & 3.26 & 1.66 & 0.8 & -1028.620681 & 15.92 & 0.84 & 1.64 & 0.00 \\
\hline Z34PD & -1028.804456 & 13.92 & 3.02 & 1.68 & 0.0 & -1028.603464 & 14.42 & 0.94 & 1.66 & 0.30 \\
\hline
\end{tabular}

Table 14 Energy results for the optimized double hydrogen-bonded dimers of heteroary lcinnamic acids at two different basis sets with B3LYP DFT function combination 
Thermally (to 298K) and BSSE corrected zero-point energies (ZPEcorr) from geometry optimization checked with frequency calculations for the hydrogen-bonded dimers $(0-\mathrm{H} \ldots \mathrm{O}=\mathrm{C})$ using the optimized monomers as the input.

\begin{tabular}{lccccc}
\hline Compound & $\begin{array}{c}\text { B3LYP/CBSB7 } \\
\text { ZPE }\end{array}$ & $\begin{array}{c}\text { H-borr (He) } \\
\text { Ecorr }^{2}\end{array}$ & BSSEcorr $^{\text {(kcal/mol) }}$ & H-bond length (Å) & D $^{\circ}$ \\
\hline E2Ph33T & -2100.484734 & 15.16 & 3.31 & 1.65 & 0.01 \\
Z2Ph33T & -2100.473507 & 13.52 & 2.95 & 1.68 & 0.20 \\
Z23T33T & -2742.007903 & 13.61 & 2.94 & 1.68 & 3.96 \\
E23T33T & -2742.016754 & 15.48 & 3.27 & 1.65 & 1.35 \\
\hline E23P3Ph & -1491.025582 & 15.46 & 3.23 & 1.65 & 0.44 \\
Z23P3Ph & -1491.010583 & 13.94 & 3.42 & 1.67 & 5.64 \\
E22P33P & -1523.102579 & 15.38 & 3.25 & 1.65 & 2.30 \\
Z22P33P & -1523.094680 & 11.15 & 5.84 & 1.68 & 3.50 \\
E2Ph33P & -1491.024651 & 15.59 & 3.23 & 1.65 & 0.26 \\
Z2Ph33P & -1491.010190 & 14.20 & 3.44 & 1.67 & 5.30 \\
\hline
\end{tabular}

Table 15 Energy and hydrogen bond length data for the optimized double hydrogen-bonded dimers of $\alpha$ heteroaryl substituted cinnamic acids at B3LYP/CBSB7 level

Somewhat higher ambiguity was found in the bonding energies of the $\alpha$ substituted derivatives (11.15-15.59 kcal/mol); however, the average bond length is the same as was obtained for the heteroaryl cinnamic acid derivatives (1.65-1.68 $)$ ). Consequently, it may be stated that the properties of the double hydrogen bond are relatively independent from the structure of the molecules studied molecules, and the formation of this bond is favorable in each case, which correlates well with the results of the infrared experiments, even in the case of the pyridyl derivatives.

\subsubsection{Hydrogen-bonded tetramers and other structures}

The tetramers were constructed from the optimized dimers, and the same basis sets were used to optimize the structures. Unfortunately, the $\mathbf{6 - 3 1 + + G ( d , p )}$ basis set failed to handle the tetramers. However, the CBSB7 basis set provided with realistic data concerning the geometry and bonding energy data for each isomer. Some derivatives failed to converge with the CBSB7 set as well (indicate with red cross); however, the refined structures did converge resulting in other geometries due to the other possible interactions like the (aromatic) $\mathrm{C}-\mathrm{H} \ldots \mathrm{O}=\mathrm{C}$ hydrogen bond and various $\pi$ stacking interactions. In those cases where the convergence leads to other geometries than the hydrogen-bonded tetramer, the bond length was fixed to $300 \mathrm{pm}$ for the thienyl and $325 \mathrm{pm}$ for the selenophenyl derivatives to get precise bonding energies (BSSE 
correction was applied and the bonding energy was calculated similarly to Equation 2). An example for the hydrogen-bonded tetramer is shown in Figure 71.

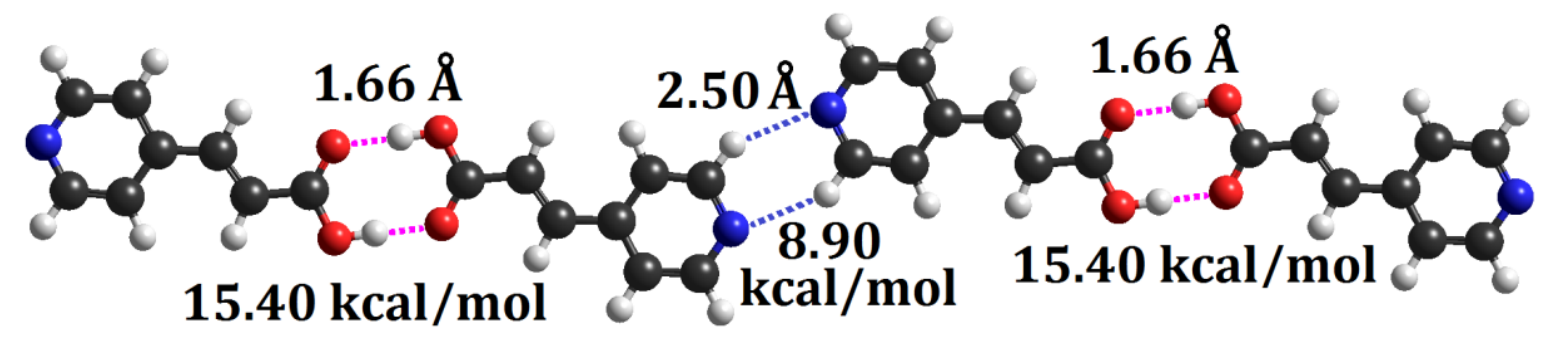

Figure 71 The hydrogen-bonded tetramer (E34PT) of E34P optimized at the B3LYP/CBSB7 level

The bonding energies and geometry parameters for the other derivatives are listed in Table 16. The energies for the (aromatic)C-H...X hydrogen bonds varied from 2.63 to $9.10 \mathrm{kcal} / \mathrm{mol}$, and in the order of (aromatic) $\mathrm{C}-\mathrm{H}$... $\mathrm{N}>$ (aromatic) $\mathrm{C}-\mathrm{H} \ldots \mathrm{O}>$ (aromatic)C-H...S > (aromatic)C-H...Se, which is similar to the results of ${ }^{1} \mathrm{H}-{ }^{1} \mathrm{H}$ COSY measurements.

Some interesting arrangements, obtained after adjusting the problems with convergence encountered with the sulphur- and selenium-containing compounds, are depicted in Figure 72.

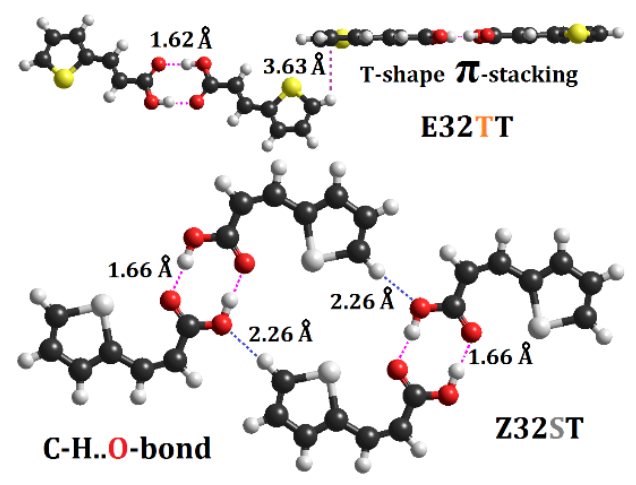

Figure $72 \mathrm{C}-\mathrm{H}$...O-bonded and $\pi$-stacked geometries from hydrogen-bonded tetramer starting structures

The arrangement for E32TT is favorable energetically, since the $\pi$-stacking energy was calculated to be $3.64 \mathrm{kcal} / \mathrm{mol}$ (BSSE corrected), which is close to that CH...S bonding energy. The arrangement obtained for Z32ST is energetically more favorable (5.02 kcal/mol, BSSE corrected) than the simple $H$-bonded version.

Due to the very high computational cost of the $\alpha$-substituted tetramers, geometry optimizations were not performed for the corresponding tetramers. 
Thermally (to 298K) and BSSE corrected zero-ooint energies (ZPE ${ }_{\text {corr }}$ ) from geometry optimization checking with frequency calculations for the hydrogen-bonded tetramers [(aromatic) $\mathrm{C}-\mathrm{H}$...X $\mathrm{X}-\mathrm{C}$ (aromatic)] using the optimized dimers as inputs.

\begin{tabular}{|c|c|c|c|c|c|c|c|c|c|c|}
\hline $\begin{array}{l}\text { Compo } \\
\text { und }\end{array}$ & $\begin{array}{c}\text { B3LYP/CBSB7 } \\
\text { ZPE }_{\text {corr }} \text { (He) }\end{array}$ & $\begin{array}{l}\text { H-bond Ecorr } \\
\text { (kcal/mol) }\end{array}$ & $\begin{array}{c}\text { BSSE }_{\text {corr }} \\
\text { (kcal/mol) }\end{array}$ & $\begin{array}{c}\text { H-bond } \\
\text { length }(\AA)\end{array}$ & $\mathbf{D}^{\circ}$ & $\begin{array}{c}\text { B3LYP/6-31++G(d,p) } \\
\text { ZPE }_{\text {corr }}(\mathrm{He})\end{array}$ & $\begin{array}{l}\text { H-bond Ecorr } \\
\text { (kcal/mol) }\end{array}$ & $\begin{array}{c}\text { BSSE }_{\text {corr }} \\
\text { (kcal/mol) }\end{array}$ & $\begin{array}{c}\text { H-bond } \\
\text { length }(\AA)\end{array}$ & $\mathbf{D}^{\circ}$ \\
\hline E32FT & -1984.639383 & 7.87 & 7.78 & 2.53 & 1.00 & -1984.222065 & 1.74 & 0.44 & 2.53 & 1.00 \\
\hline Z32FT & -1984.616973 & 7.14 & 7.34 & 2.57 & 0.07 & -1984.200984 & 1.97 & 0.36 & 2.57 & 0.09 \\
\hline E33FT & -1984.616798 & 7.78 & 7.92 & 2.56 & 2.30 & -1984.200594 & 1.76 & 0.35 & 2.56 & 4.53 \\
\hline Z33FT & -1984.595946 & 7.49 & 7.47 & 2.56 & 0.03 & -1984.179941 & 2.49 & 0.35 & 2.56 & 0.02 \\
\hline E32TT & -3276.575778 & 4.49 & 7.22 & 3.00 & 0.00 & -3276.119813 & -0.15 & 0.34 & 3.00 & 0.00 \\
\hline Z32TT & -3276.548557 & 3.95 & 6.55 & 3.00 & 0.00 & -3276.088814 & -1.22 & 0.31 & 3.00 & 0.00 \\
\hline E33TT & -3276.572734 & 5.38 & 6.55 & 3.00 & 0.00 & -3276.114264 & -0.38 & 0.29 & 3.00 & 0.00 \\
\hline Z33TT & -3276.547281 & 4.79 & 6.46 & 3.00 & 0.00 & -3276.087813 & -0.24 & 0.30 & 3.00 & 0.00 \\
\hline E32ST & -11289.85939 & 2.63 & 7.18 & 3.25 & 0.00 & -11280.99572 & -2.65 & 2.80 & 3.25 & 0.00 \\
\hline Z32ST & -11289.85055 & 4.79 & 7.28 & 3.25 & 0.00 & -11280.99213 & 4.57 & 4.37 & 3.25 & 0.00 \\
\hline E33ST & -11289.85471 & 4.84 & 7.20 & 3.25 & 0.00 & -11280.98673 & -1.10 & 3.41 & 3.25 & 0.00 \\
\hline Z33ST & -11289.82577 & 3.37 & 6.57 & 3.25 & 0.00 & -11280.96711 & 1.25 & 2.09 & 3.25 & 0.00 \\
\hline E32PT & -2057.662339 & 8.14 & 8.14 & 2.53 & 0.00 & -2057.252594 & 3.13 & 0.41 & 2.53 & 0.00 \\
\hline Z32PT & -2057.636666 & 7.37 & 7.57 & 2.54 & 0.00 & -2057.226827 & 3.26 & 0.32 & 2.54 & 0.00 \\
\hline E33PT & -2057.660002 & 9.10 & 8.14 & 2.50 & 0.00 & -2057.249931 & 2.51 & 0.38 & 2.51 & 0.01 \\
\hline Z33PT & -2057.620182 & 7.95 & 7.95 & 2.51 & 0.00 & -2057.210314 & 3.57 & 0.35 & 2.51 & 0.00 \\
\hline E34PT & -2057.656222 & 8.90 & 8.07 & 2.50 & 0.03 & -2057.246441 & 2.86 & 0.34 & 2.50 & 0.02 \\
\hline Z34PT & -2057.622386 & 8.46 & 7.60 & 2.49 & 0.00 & -2057.212465 & 3.47 & 0.31 & 2.49 & 0.00 \\
\hline
\end{tabular}

Table 16 Energy and geometry data for the optimized hydrogen-bonded tetramers using two different basis sets with the B3LYP functional 


\subsubsection{M-stacking interactions}

The "sandwich" type $\pi$-stacking was the final intermolecular interaction studied. The optimized monomers (WB97XD/CBSB7 and WB97XD/6-31++G(d,p)) were used to construct the starting geometries, and the selected distances among the centers of the aromatic rings was $3.9 \AA$, based on literature data. One example for the structure is presented with E34P- $\pi$ in Figure 73.

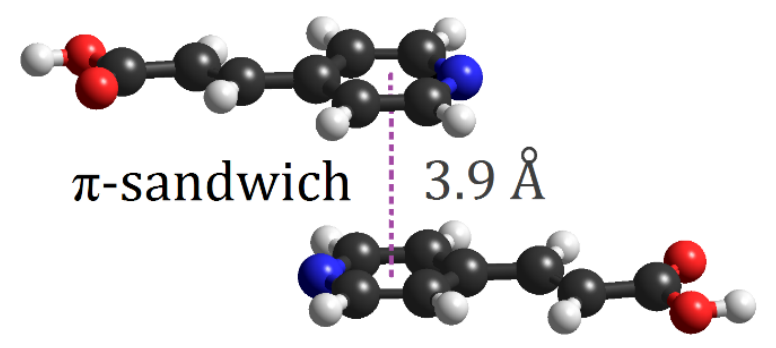

Figure 73 „Sandwich”-type $\pi$-stacking interaction presented with E34P molecules

The resulting bonding energies were calculated similarly to Equation 2, (BSSE corrected as well), they correlate well with the literature data (calculated for benzene); the difference was about $1.5 \mathrm{kcal} / \mathrm{mol}$. The resulting energies with two different basis sets are listed in Table 17.

Similar calculations could not be performed for the $\alpha$-substituted variants, because of geometric reasons. The molecules are too congested; consequently, proper starting geometries could not be constructed. 
Thermally (to 298K) and BSSE corrected zero-point energies (ZPE checked with frequency calculations for "sandwich" type $\pi$-stacked dimer using the optimized monomers as inputs.

\begin{tabular}{|c|c|c|c|c|c|c|}
\hline Compound & $\begin{array}{c}\text { WB97XD/C } \\
\text { BSB7 } \\
\text { ZPE }_{\text {corr }} \text { (He) }\end{array}$ & $\begin{array}{c}\pi \text {-stacking } \\
\text { Ecorr }_{\text {col }} \\
\text { (kcal/mol) }\end{array}$ & $\begin{array}{c}\text { BSSE }_{\text {corr }} \\
\text { (kcal/mol) }\end{array}$ & $\begin{array}{l}\text { WB97XD/6- } \\
31++G(d, p) \\
Z E_{\text {corr }}(\mathrm{He})\end{array}$ & 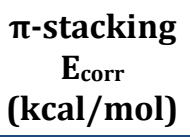 & $\begin{array}{c}\text { BSSEcorr }_{\text {(kcal/mol) }} \\
\text { (kcalmol }\end{array}$ \\
\hline E32F- $\pi$ & -991.94894 & 3.88 & 0.81 & -991.7505443 & 3.53 & 0.62 \\
\hline Z32F- $\pi$ & -991.9406 & 3.77 & 0.90 & -991.7422873 & 3.45 & 0.67 \\
\hline E33F- $\pi$ & -991.9392 & 2.90 & 0.65 & -991.740967 & 2.51 & 0.59 \\
\hline Z33F- $\pi$ & -991.93291 & 3.49 & 0.76 & -991.7345347 & 3.27 & 0.73 \\
\hline E32T- $\pi$ & -1637.9305 & 4.58 & 1.23 & -1637.711069 & 4.27 & 0.82 \\
\hline Z32T- $\pi$ & -1637.9183 & 3.86 & 1.12 & -1637.697621 & 3.57 & 0.86 \\
\hline E33T- $\pi$ & -1637.9302 & 4.33 & 1.10 & -1637.710048 & 3.92 & 0.83 \\
\hline Z33T- $\pi$ & -1637.9211 & 4.59 & 1.40 & -1637.70047 & 4.35 & 1.02 \\
\hline E32S- $\pi$ & -5644.6608 & 4.19 & 0.77 & -5640.223655 & 3.79 & 8.84 \\
\hline Z32S- $\pi$ & -5644.6557 & 4.02 & 0.83 & -5640.217944 & 3.76 & 8.21 \\
\hline E33S- $\pi$ & -5644.6595 & 4.40 & 0.80 & -5640.220386 & 3.93 & 9.65 \\
\hline Z33S- $\pi$ & -5644.6497 & 4.87 & 0.91 & -5640.212855 & 4.63 & 8.52 \\
\hline E32P- $\pi$ & -1028.4473 & 4.80 & 0.73 & -1028.251805 & 4.43 & 0.66 \\
\hline 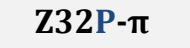 & -1028.4315 & 4.35 & 0.79 & -1028.235965 & 4.03 & 0.62 \\
\hline E33P- $\pi$ & -1028.4399 & 4.45 & 0.70 & -1028.244973 & 4.14 & 0.62 \\
\hline Z33P- $\pi$ & -1028.427 & 3.54 & 0.74 & -1028.231579 & 3.14 & 0.63 \\
\hline E34P- $\pi$ & -1028.4364 & 3.11 & 0.60 & -1028.241734 & 2.82 & 0.56 \\
\hline 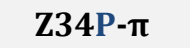 & -1028.4238 & 4.39 & 0.83 & -1028.228775 & 4.21 & 0.74 \\
\hline
\end{tabular}

Table 17 Energy and geometry data for the optimized $\pi$-stacked dimers using two different basis sets with the WB97XD functional 


\section{SUMMARY}

The family of cinnamic acids (E-3-phenylpropenoic acids) and they derivatives are discovered 140 years ago; however, they are still intensively studied materials due to their wide-ranging application possibilities (UV-protection, food preservation, producing chemical intermediates and pharmacological products, etc.). In spite of the mentioned applications, one can only find a few literature examples for the preparation, characterization and practical uses of the heterocyclic derivatives and the $Z$ isomers of cinnamic acids (for both 3-arylpropenoic and 2,3-arylpropenoic acids); therefore studying these compounds is still relevant.

During the experimental work leading to this dissertation, a variety of $E$ and $Z$ cinnamic acids were synthesized, including furyl-, thienyl-, selenophenyl-, and pyridylcinnamic acids and some $\alpha$-substituted variations containing thienyl or pyridyl groups, applying numerous types of condensation reactions like the Perkin-, KövenagelDöbner- (leading to the thermodynamically more favorable $E$ isomer) and several, modified Horner-Wadsworth-Emmons reactions (HWE) (which can be both E- or Zselective depending on the reagent and the circumstances). The synthesized materials were extensively characterized by various methods including several spectroscopic techniques, like infrared spectroscopy (IR), nuclear magnetic spectroscopy (NMR) with numerous 1D and 2D techniques and other analytical tools, e.g. X-ray diffractometry (XRD), atomic force microscopy (AFM) and infrared microspectroscopy (IRM). The experimental findings were checked by quantum chemical calculations performed at various theoretical levels (PM6, HF/6-31G(d,p), B3LYP/CBSB7, WB97XD/CBSB7).

For the synthesis of stereochemically pure E-3-heteroarylcinnamic acids, the Knövenagel-Döbner condensation with slight modifications (mostly in the reaction time, temperatures and the processing of the reaction mixture) was found to be a general method providing impressive yields and selectivity $(100 \%$ E-selectivity and $>95 \%$ yields were observed). It was found that the $E$ - $\alpha$-substituted variants can be prepared via both modified Perkin and traditional HWE synthesis; however, the HWE technique performed much better (selectivity could be adjusted and the yields were $>90 \%$ ) than the Perkin reaction. The hardly accessible Z-3-heteroarylcinnamic acids were synthesized as well applying the modified HWE-reaction, where the reagent was the Ando-phosphonate. Due to the stabilized intermediate (under cryogenic conditions and inert atmosphere) 90:10 
$(Z: E)$ selectivity was achieved in most cases, and the yields were also good (>90\%). The UV-induced photoisomerization was found to be an affordable and simple method for the preparation of the Z-isomers, on the other hand the separation of the isomer mixtures, requires special equipment.

The structure forming properties of the synthesized derivatives were studied with the combination of various instrumental methods in the solid, the liquid (in solution) and in the adsorbed phase as well. Infrared spectroscopy revealed that both $E$ and Z-cinnamic acids (3- and 2,3-arylpropenoic acids) derivatives containing a phenyl- or a five-membered ring, form cyclic double hydrogen bonds via the carboxylic groups in the solid state and in solution as well, if the solvent is aprotic (chloroform or DMSO). Only the pyridyl variants act differently, where the fundamental structure in the crystalline phase was the zwitterion. Nevertheless, it was confirmed that in DMSO, the formation of the hydrogen-bonded dimers were also possible. Comparing the infrared results, (registered in different phases) the presence of possible weaker interactions, like $\mathrm{C}-\mathrm{H} \ldots \mathrm{X}(\mathrm{O}, \mathrm{S}, \mathrm{N}, \mathrm{Se})$ hydrogen bonds among the aromatic protons and the heteroatom, or the olefinic proton and the carboxylic oxygen, are very feasible, because significant shifts in the aromatic vibrations could be identified in the spectra.

The results of the ${ }^{1} \mathrm{H}-1 \mathrm{H}$ correlation spectroscopy (COSY) in saturated solution in DMSO, prove the presence of the previous interactions, especially the one between the aromatic rings, where a variety of intermolecular hydrogen bonds appeared as offdiagonal cross-peaks, with weak coupling between the non-neighboring protons. Another sign of hydrogen bonds was found as well: the signal broadening of the aromatic protons (on the ${ }^{1} \mathrm{H}$ spectra), which was significantly larger compared to olefinic protons. These findings proved that the olefinic protons were not involved in the extended hydrogen-bonded systems in solution. ${ }^{1} \mathrm{H}-1 \mathrm{H}$ nuclear Overhauser effect spectroscopy (NOESY) was found to be useful in gaining some information about the conformational behavior of the materials studied. The results show that the aromatic ring of the 3heteroaryl derivatives, rotate freely in dilute (0.05 M in DMSO) solution, on the other hand, the result for the 2,3-variants was quite different. The ring on the second carbon rotates relatively freely, but the conformational space of the other one on the third carbon was slightly hindered. 
The self-assembling capabilities were further investigated over polycrystalline metal surfaces (gold and silver, created with the PLD method) applying the dip-coating method in $0.1 \mathrm{M}$ solution in chloroform. The created molecular layers were studied with the combination of IRM and AFM techniques. The results of the IRM measurements confirmed that the adsorption of the molecules on the metal surfaces was successful. Further imaging with AFM revealed some interesting, highly organized formations, where the layer thickness was far larger than monomolecular. The presence of the already mentioned hydrogen bonds was found to be predominant. Due to the very high peaks on the surface $\pi$-stacking was also assumed.

The results of the conformational analysis revealed the complete potential energy surfaces of the heteroaryl cinnamic acid derivatives and the stable conformers of the $\alpha$ substituted variants. The properties of the conformational space showed consistency with the NOESY experiments. The most stable conformers (determined by the conformational analysis) were further optimized at higher levels, and completely planar structure was found for the heteroaryl cinnamic acid and twisted geometries for the other derivatives. Geometry and energy data for the hydrogen bonded dimers proved that the fundamental unit was the dimer with $15 \mathrm{kcal} / \mathrm{mol}$ average bonding energy. This finding correlates well with the IR measurements. The possible energy order of the weaker hydrogen bonds and $\pi$-stacking interactions were determined successfully as well: $\mathrm{C}-\mathrm{H} \ldots \mathrm{N}>\mathrm{C}-\mathrm{H} \ldots \mathrm{O}>\mathrm{C}-\mathrm{H} \ldots \mathrm{S} \sim \pi-\pi>\mathrm{C}-\mathrm{H}$...Se, which is very similar to the experimental findings.

The above-listed results clearly attest that heteroaryl cinnamic acids are versatile materials. They can form various, extended hydrogen-bonded structures in any studied phases. Among many already mentioned applications, the derivatives studied here can have applications in the field of electronics and can act as anticorrosion agents due to their behavior over metal surfaces. Furthermore, they may have pharmacological effects making them interesting target for the medical industry as well. 


\section{RELATED PUBLICATIONS}

[1] Csankó, K., Darányi, M., Kozma, G., Kukovecz, Á., Kónya, Z., Sipos, P. Pálinkó, I.:

Self-assembling of $Z$ - $\alpha$-pyridylcinnamic acid dimers over polycrystalline $\mathrm{Ag}$ and $\mathrm{Au}$ surfaces followed by FT-IR and atomic force microscopies,

J. Mol. Struct. 993, 67-72 (2011).

IF: 1.551

[2] Csankó, K., Illés, L., Felföldi, K., Kiss, J.T., Sipos, P., Pálinkó, I.:

C-H...S hydrogen bonds as the organising force in 2,3-thienyl- and phenyl- or 2,3dithienyl-substituted propenoic acid aggregates studied by the combination of FT-IR spectroscopy and computations,

J. Mol. Struct. 993, 259-263 (2011).

IF: 1.551

[3] Csankó, K., Forgo P, Boros, K., Hohmann, J., Sipos, P., Pálinkó I.,:

Conformational properties of a pyridylsubstituted cinnamic acid studied by NMR measurements and computations,

J. Mol. Struct, 1044, 286-289 (2013).

IF: 1.599

[4] Csankó, K., Kozma, G., Valkai, L., Kukovecz, Á., Kónya, Z., Sipos, P., Pálinkó, I.:

Self-assembling of 2,3-phenyl/thienyl-substituted acrylic acids over polycrystalline gold, J. Mol. Struct, 1044, 32-38 (2013).

IF: 1.599

[5] Csankó, K., Ruusuvuori, K.I., Tolnai, B., Sipos, P., Berkesi, O., Pálinkó, I.:

Structural features of pyridylcinnamic acid dimers and their extended hydrogen-bonded aggregations

J. Mol. Struct., in press, doi:10.1016/j.molstruc.2014.11.041, (2014)

IF: 1.599 


\section{OTHER PUBLICATIONS}

[1] Csankó, K., Sipos, P., Pálinkó, I.: Monometallic supported gold catalysts in organic transformations: Ring making and ring breaking,

Catalysts 2, 101-120 (2012).

IF: - 


\section{REFERENCES}

[1]. Köhler, F. E.; Wilhelm, B.; Gürke, M., Medizinal-Pflanzen in naturgetreuen Abbildungen mit kurz erläuterndem Gera-Untermhaus: Wien, 1887. Vol. 1, p 7777.

[2]. Toussaint-Samat, M., A history of food. Wiley-Blackwell: Malden, 2009. p 433-490.

[3]. Paranagama, P. A.; Wimalasena, S.; Jayatilake, G. S.; Jayawardena, A. L.; Senanayake, U. M.; Mubarak, A. M., J. Natn. Sci. Foundation Sri Lanka 2001. 29, 147-153.

[4]. Letizia, C. S.; Cocchiara, J.; Lapczinsky, A., Food Chem. Toxicol. 2005. 43, 925-943.

[5]. Hill, L.; Gomes, C.; Taylor, M., Food. Sci. Tech. 2013. 51, 86-93.

[6]. Pound, A. W.; Pound, J. R., J. Phys. Chem. 1933. 38, 1045-1049.

[7]. Perkin, W., J. Chem. Soc. 1868. 21, 181-186.

[8]. Urbach, F., Biological responses to ultraviolet $A$ radiation. Valdenmar: Oxford, 1991.

[9]. Beavis, R. C.; Chait, B. T.; Fales, H. M., Rapid Commun. Mass Spectrom. 1989. 3, 432-435.

[10]. Kiss, J. T.; Felföldi, K.; Körtvélyesi, T.; Pálinkó, I., Vibr. Spect. 2000. 22, 63-73.

[11]. Török, B.; Pálinkó, I.; Tasi, G.; Nyerges, L.; Bogár, F., J. Chromat. A 1994. 668, 353358.

[12]. Pálinkó, I.; Török, B.; Rózsa-Tarjányi, M.; Kiss, J. T.; Tasi, G., J. Mol. Struct. 1995. 348, 57-60.

[13]. Kukovecz, Á.; Kiss, J. T.; Pálinkó, I., J. Mol. Struct. 1997. 408-409, 325-327.

[14]. Kiss, J. T.; Felföldi, K.; Hannus, I.; Pálinkó, I., J. Mol. Struct. 2001. 565-566, 463468.

[15]. Ladell, J.; McDonald, T. R. R.; Schmidt, G. M. J., Acta Cryst. 1956. 9, 195-195.

[16]. Luo, G.; Yang, R.; Lai, X.; Yang, W.; Xie, S.; Zhou, H., China j. Chinese mater. med. 1996. 21, 744-763.

[17]. Maranz, S.; Wiesman, Z.; Garti, N., Journal of agricultural and food chemistry 2003. $51,6268-73$.

[18]. Douglas, C.; Hoffmann, H.; Schulz, W.; Hahlbrock, K., EMBO J. 1987. 6, 1189-1195.

[19]. Peter, K. L.; Corlett, R.; H.T.W., T., Singapore Biodiversity: An Encyclopedia Of The Natural Environment And Sustainable Development. Didier Millet: Singapore, 2011.

[20]. Li, X. W.; Li, J.; Werff, H., Flora of China. Harvard university press: Cambridge, 2013. pp 38-39.

[21]. Dumas, J. B.; Préligot, E., Ann. Chim. Physique 1834. 57, 305-334.

[22]. Chiozza, L., Compt. Rend. 1854. 1, 222-222.

[23]. Promkatkaew, M.; Suramitr, S.; Karpkird, T. M.; Namuangruk, S.; Ehara, M.; Hannongbua, S., J. Chem. Phys. 2009. 131, 224-306. 
[24]. Blake, J.; Walker, G. N.; Fish, M. S., Org. Synth. Coll. 1951. 31, 35-35.

[25]. Ford, R. A.; Domeyer, B.; Easterday, O., Regul. Toxicol. Pharmacol. 2000. 31, 166181.

[26]. Karas, M.; Bachmann, D.; Hillenkamp, F., Anal. Chem. 1985. 57, 2935-2939.

[27]. Hillenkamp, F.; Karas, M.; Bachmann, D., Int. J. Mass. 1987. 78, 53-68.

[28]. Hillenkamp, F.; Karas, M., Anal. Chem. 1988. 60, 2299-2301.

[29]. Beavis, R. C.; Chait, B. T., Rapid Commun. Mass Spectrom. 1989. 3, 436-439.

[30]. Beavis, R. C.; Chait, B. T.; Chaudhary, T., Org. Mass Spectrom. 1992. 27, 156-158.

[31]. Hermann, K. M., Plant Cell 1995. 7, 907-919.

[32]. Rosen, T., In Comprehensive Organic Synthesis, Elsevier: 1991. pp 395-408.

[33]. Dippy, J. F. J.; Evans, R. M., J. Org. Chem. 1950. 15, 451-456.

[34]. Johnson, J. R., The Perkin Reaction and Related Reactions. In Organic Reactions, John Wiley \& Sons, Inc.: 2004.

[35]. Raj, K.; Johnson, J. R., Organic Reaction Mechanism. In Organic Reactions, John Wiley \& Sons, Inc.: 1998. pp 199-201.

[36]. Buckles, R. E.; Hausman, E. A., J. Am. Chem. Soc. 1948. 70, 415-415.

[37]. Claisen, L., Ber. 1890. 23, 977-977.

[38]. Schmidt, J., Ber. 1881. 14, 1459-1461.

[39]. Knoevenagel, E., Ber. 1898. 31, 2596-2619.

[40]. Doebner, 0., Chem. Ber. 1902. 35, 1136-1136.

[41]. Bruckner, R., Organic mechanisms. Springer: 2002. pp 423-423.

[42]. Wiley, R. H.; Smith, N. R., J. Am. Chem. Soc. 1950. 72, 5198-5199.

[43]. Kuhn, R.; Badstuber, W.; Grundmann, C., Chem. Ber. 1936. 69, 98-98.

[44]. Berslow, D. S.; Hauser, C. R., J. Am. Chem. Soc. 1940. 62, 2385-2388.

[45]. List, B., Angew. Chem. Int. Ed. Eng. 2010. 49, 1730-1734.

[46]. Heck, R. F.; Nolley, J. P., J. Org. Chem. 1972.37, 2320-2322.

[47]. Mizoroki, T.; Mori, K.; Ozaki, A., Bull. Chem. Soc. Jap 1971. 44, 581-581.

[48]. Tierney, J. P.; Lidström, P., Microwave Assisted Organic Synthesis. Blackwell: Oxford, 2006. pp 1-21.

[49]. Mobinikhaledi, A.; Foroughifar, N.; Fathinejad, H., Syn. React. Inorg. Met. 2008. 38, 428-430.

[50]. Gupta, M.; Wakhloo, B. P., Arkivoc. 2007. 1, 94-98.

[51]. Rohatgi-Mukherjee, K. K., Fundamentals of photochemistry. 1997. pp 1-218.

[52]. Rao, Y. S.; Filler, R., Chem. Comm. 1976. 471-472.

[53]. Hocking, M. B., Can. J. Chem. 1969. 47, 4567-4576.

[54]. Khan, M.; Brunklaus, G.; Enkelmann, V., J. Am. Chem. Soc. 2008. 130, 1741-1748. 
[55]. Lindlar, H., Helv. Chim. Acta 1952. 35, 446-450.

[56]. García-Mota, M.; Gómez-Díaz, J.; Novell-Leruth, G.; Vargas-Fuentes, C.; Bellarosa, L.; Bridier, B.; Pérez-Ramírez, J.; López, N., Theor Chem Acc 2011. 128, 663-673.

[57]. Urushibara, Y.; Hirota, M., Nippon Kagaku Zasshi 1964. 85, 679-681.

[58]. Brown, C. A.; Ahuja, V. K., Chem. Comm. 1973. 553-554.

[59]. Wadsworth, W. S., Org. React. 1977. 25, 73-73.

[60]. Horner, L.; Hoffmann, H.; Wippel, H. G., Chem. Ber. 1958. 91, 61-63.

[61]. Wadsworth, W. S.; Emmons, W. D., J. Am. Chem. Soc. 1961. 83, 1733-1738.

[62]. Wittig, G.; Schöllkopf, U., Chem. Ber. 1954. 87, 1318-1318.

[63]. Wittig, G.; Haag, W., Chem. Ber. 1955. 88, 1654-1666.

[64]. Michaelis, A.; Kaehne, R., Ber. 1898. 31, 1048-1055.

[65]. Arbuzov, A. E., J. Russ. Phys. Chem. Soc. 1906. 38, 687-687.

[66]. Bhattacharya, A. K.; Thyagarajan, G., Chem. Rev. 1981. 81, 415-430.

[67]. Larsen, R. O.; Aksnes, G., Phosph. Sulf. 1983. 15, 218-219.

[68]. Still, W. C.; Gennari, C., Tetrahedron Lett. 1983. 24, 4405-4408.

[69]. Breuer, E.; Bannet, D. M., Tetrahedron Lett. 1977. 18, 1141-1144.

[70]. Patois, C.; Savignac, P., Tetrahedron Lett. 1991. 32, 1317-1320.

[71]. Ando, K., J. Org. Chem. 1999. 64, 8406-8408.

[72]. Hoveyda, A. H.; Zhugralin, A. R., Nature 2007. 450, 243-251.

[73]. Siau, W. Y.; Zhang, Y.; Zhao, Y., Top. Curr. Chem. 2012. 327, 33-58.

[74]. Crowe, W. E.; Goldberg, D. R., J. Am. Chem. Soc. 1995. 117, 5162-5163.

[75]. Buckles, R. E.; Bremer, K., Org. Synth. Coll. 1953. 33, 70-70.

[76]. Karaminski-Zamola, G.; Fiser-Jakic, L.; Bajic, M., Heterocycles 1985. 23, 313-316.

[77]. Kharasch, M. S.; Jensen, E. V.; Urry, W. H., Science 1945. 102, 128-128.

[78]. Cadogan, J. I. G.; Duell, E. G., J. Chem. Soc. 1962. (Resumed), 4154-4163.

[79]. Li, S.; Yuan, W.; Ma, S., Ang. Chem. Int. Ed. Eng. 2011. 50, 2578-2582.

[80]. Arunan, E.; Desiraju Gautam, R.; Klein, R. A.; Sadlej, J.; Scheiner, S.; Alkorta, I.; Clary David, C.; Crabtree, R. H.; Dannenberg, J. J.; Hobza, P.; Kjaergaard, H. G.; Legon, A. C.; Mennucci, B.; Nesbitt, D. J., Pure Appl. Chem. 2011. 83, 1637-1637.

[81]. Emsley, J., Chem. Soc. Rev. 1980. 9, 91-124.

[82]. Tolnai, B.; Kiss, J. T.; Felföldi, K.; Pálinkó, I., J. Mol. Struct. 2009. 924-926, 27-31.

[83]. Tamasi, G.; Defazio, S.; Chiasserini, L.; Sega, A.; Cini, R., Inorg. Chim. Acta 2009. 362, 1011-1021.

[84]. Filippov, O. A.; Belkova, N. V.; Epstein, L. M.; Shubina, E. S., J. Organomet. Chem. 2013. $747,30-42$.

[85]. Custelcean, R.; Jackson, J. E., Chem. Rev. 2001. 101, 1963-1980. 
[86]. Hopkins, J. C.; Dryden, D. M.; Ching, W. Y.; French, R. H.; Parsegian, V. A.; Podgornik, R., J. Coll. Interf. Sci. 2014. 417, 278-284.

[87]. Hunter, C. A.; Sanders, J. K. M., J. Am. Chem. Soc. 1990. 112, 5525-5534.

[88]. Sinnokrot, M. O.; Valeev, E. F.; Sherrill, C. D., J. Am. Chem. Soc. 2002. 124, 1088710893.

[89]. Metrangolo, P.; Resnati, G., Chem. Eur. J. 2001. 7, 2511-2519.

[90]. Isaacs, E. D.; Shukla, A.; Platzman, P. M.; Hamann, D. R.; Barbiellini, B.; Tulk, C. A., Phys. Rev. Lett. 1999. 82, 600-603.

[91]. Yakovchuk, P.; Protozanova, E.; Frank-Kamenetskii, M. D., Nucleic Acid Res. 2006. 34, 564-574.

[92]. Chermahini, A. N.; Mahdivan, M.; Teimouri, A., Bull. Korean Chem. Soc. 2010. 31, 941-948.

[93]. Sauren, H.; Winkler, A.; Hess, P., Chem. Phys. Lett. 1995. 239, 313-319.

[94]. Navarrete, A.; Somanathan, R.; Aguirre, G., Acta Cryst. 2013. 69, 1519.

[95]. Pálinkó, I., Acta Cryst. 1999. 55, 216-220.

[96]. Gou, Q.; Feng, G.; Evangelisti, L.; Caminati, W., Chem. Phys. Lett. 2014. 591, 301305.

[97]. Kukovecz, Á.; Pálinkó, I., J. Mol. Struct. 1999. 482-483, 463-467.

[98]. Gorbitz, C. H.; Etter, M. C., J. Am. Chem. Soc. 1992. 114, 627-631.

[99]. Nagy, P. I., Comp. Theor. Chem. 2013. 1022, 59-69.

[100]. Hyla-Kryspin, I.; Haufe, G.; Grimme, S., Chem. Phys. 2008. 346, 224-236.

[101]. Balogh, Z.; Pálinkó, I., J. Mol. Struct. THEOCHEM 2003. 623, 11-15.

[102]. Nobeli, I.; Price, S. L.; Lommerse, J. P. M.; Taylor, R., J. Comp. Chem. 1997. 18, 20602074.

[103]. Peña Ruiz, T.; Fernández-Gómez, M.; López González, J. J.; Koziol, A. E.; Granadino Roldán, J. M., J. Mol. Struct. 2004. 707, 33-46.

[104]. Chakrabarti, P.; Chakrabarti, S., J. Mol. Biol. 1998. 284, 867-873.

[105]. McGaughey, G. B.; Gagné, M.; Rappé, A. K., J. Biol. Chem. 1998. 273, 15458-15463.

[106]. Cockroft, S. L.; Hunter, C. A.; Lawson, K. R.; Perkins, J.; Urch, C. J., J. Am. Chem. Soc. 2005. 127, 8594-8595.

[107]. Ringer, A. L.; Sinnokrot, M. O.; Lively, R. P.; Sherrill, C. D., Chem. Eur. J. 2006. 12, 3821-3828.

[108]. Sinnokrot, M. O.; Sherrill, C. D., J. Phys. Chem. A 2004. 108, 10200-10207.

[109]. Fernandes, M. A.; Levendis, D. C.; Koning, C. B., Cryst. Eng. 2001. 4, 215-231.

[110]. Love, J. C.; Estroff, L. A.; Kriebel, J. K.; Nuzzo, R. G.; Whitesides, G. M., Chem. Rev. 2005. 105, 1103-1170.

[111]. Grönbeck, H.; Curioni, A.; Andreoni, W., J. Am. Chem. Soc. 2000. 122, 3839-3842. 
[112]. Vericat, C.; Vela, M. E.; Benitez, G.; Carro, P.; Salvarezza, R. C., Chem. Soc. Rev. 2010. 39, 1805-1834.

[113]. Gómez, M. M.; Vara, J. M.; Hernández , J. C.; Salvarezza, R. C.; Arvia, A. J., J. Electro. Chem. 1999. 474, 74-81.

[114]. Muniz-Miranda, M., Chem. Phys. Lett. 2006. 417, 330-333.

[115]. Matsuura, T.; Shimoyama, Y., Eur. Phys. J. E 2002. 7, 233-240.

[116]. Poppenberg, J.; Richter, S.; Darlatt, E.; Traulsen, C. H. H.; Min, H.; Unger, W. E. S.; Schalley, C. A., Surf. Sci. 2012. 606, 367-377.

[117]. Baše, T.; Bastl, Z.; Havránek, V.; Lang, K.; Bould, J.; Londesborough, M. G. S.; Macháček, J.; Plešek, J., Surf. Coat. Tech. 2010. 204, 2639-2646.

[118]. Huang, I. Y.; Lee, M. C., Sensor. Actuat. B-Chem. 2008. 132, 340-348.

[119]. Witte, G.; Wöll, C., J. Mater. Res. 2004. 19, 1889-1916.

[120]. Gooding, J. J.; Mearns, F.; Yang, W.; Liu, J., Electroanalysis 2003. 15, 81-96.

[121]. Iler, R. K., J. Coll. Interf. Sci. 1966. 21, 569-594.

[122]. Decher, G.; Hong, J. D., Makromol. Chem. M. Symp. 1991. 46, 321-327.

[123]. Kotov, N. A., Nanostruct. Mater. 1999. 12, 789-796.

[124]. Lin, Z. P.; Guo, B. B., Guangpu Shiyanshi 2012. 29, 1786-1788.

[125]. Pastoriza-Santos, I.; Liz-Marzán, L. M., Pure appl. chem. 2000. 72, 83-90.

[126]. AIST 1H NMR (E-cinnamic acid).2014.

[127]. Marvel, C. S.; King, W. B., Org. Synth. Coll. 1929. 1, 252.

[128]. Chandrasekhar, S.; Reddy, G. P. K.; Nagesh, C.; Reddy, C. R., Tetrahedron Lett. 2007. 48, 1269-1271.

[129]. Dean, E. W.; Stark, D. D., J. Ind. Eng. Chem. 1920. 12, 486-490.

[130]. Allen, C. F. H.; Spangler, W. F., Org. Synth. Coll. 1955. 3, 377-377.

[131]. Zhanglin, Z.; Lilan, S.; Yaozeng, H., Synt. Comm. 1991. 21, 1027-1037.

[132]. Rahman, M. A. F. M.; Jahng, Y., Eur. J. Org. Chem. 2007. 379-383.

[133]. Sigma-Aldrich 1H NMR (E-3-(2-thienl)acrylic acid).2014.

[134]. Sigma-Aldrich 1H NMR (E-3-(3-pyridyl)acrylic acid).2014.

[135]. Bio-Rad 1H NMR (NQ_05356).2005.

[136]. Abott, T. W.; Althousen, D., Org. Synth. Coll. 1932. 2, 270-270.

[137]. Abott, T. W., Org. Synth. Coll. 1932. 2, 515-515.

[138]. Sigma-Aldrich 1H NMR (3-phenylpropiolic acid).2014.

[139]. Kurita, T.; Aoki, F.; Mizumoto, T.; Maejima, T.; Esaki, H.; Maegawa, T.; Monguchi, Y.; Sajiki, H., Chem. Eur. J. 2008. 14, 3371-3379.

[140]. Lindlar, H.; Dubuis, R., Org. Synth. Coll. 1973. 5, 880-880.

[141]. Trost, B. M.; Hirano, K., Org. Lett. 2012. 14, 2446-2449. 
[142]. Scapens, D.; Adams, H.; Johnson, T. R.; Mann, B. E.; Sawle, P.; Aqil, R.; Perrior, T.; Motterlini, R., Dalton Trans. 2007. 43, 4962-4973.

[143]. Yao, Q.; Levchik, S., Tetrahedron Lett. 2006. 47, 277-281.

[144]. Messik, F.; Oberthür, M., Synthesis 2013. 45, 167-170.

[145]. Richardson, R. M. New synthesis and reactions of phosphonates. University of Iowa, 2012.

[146]. Carpino L.A.; McAdams, L. V., Org. Synth. Coll. 1970. 50, 31-31.

[147]. Thompson, M. Arguslab, 4.01; Planaria Software LLC: 2005.

[148]. Hyperchem, T. Hyperchem Professional 8.0.6, 8.0.6; Hypercube Inc. 1115 NW 4th Street, Gainesville, Florida 32601, USA: 2007.

[149]. J. J. P. Stewart, J. Comp. Chem. 1989. 10, 209-20.

[150]. Roothaan, C. C. J., Rev. Mod. Phys. 1951. 23, 69-69.

[151]. Collins, J. B.; Schleyer, P. R.; Binkley, J. S.; Pople, J. A., J. Chem. Phys. 1976. 64, 514251.

[152]. Gaussian, I. Gaussain 09, Revision D.01, Gaussian, Inc., Wallingford CT: 2013.

[153]. IRC, g. Avogadro, 1.1.1; 2013.

[154]. Stewart, J. J., J. Mol. Model. 2007. 13, 1173-213.

[155]. Ditchfield, R.; Hehre, W. J.; Pople, J. A., J. Chem. Phys. 1971. 54, 724-724.

[156]. Becke, A. D., J. Chem. Phys. 1993. 98, 5648-5652.

[157]. Clark, T.; Chandrasekhar, J.; Spitznagel, G. W.; Schleyer, P. R., J. Comp. Chem. 1983, 294-301.

[158]. J. A. Montgomery, J. A.; Frisch, J. M. J.; Ochterski, J. W.; Petersson, G. A., J. Chem. Phys. 1999. 110, 2822-2827.

[159]. Head-Gordon M.; Pople, J. A.; Frisch, M. J., Chem. Phys. Lett. 1988. 153, 503-506.

[160]. Chai, J. D.; Head-Gordon, M., PCCP 2008. 10, 6615-6620.

[161]. Simon, S.; Duran, M.; Dannenberg, J. J., J. Chem. Phys. 1996. 105, 11024-11032.

[162]. Boys, S. F.; Bernardi, F., Mol. Phys. 1970. 19, 553.

[163]. Bondi, A., J. Phys. Chem. 1964. 68, 441. 


\section{MAGYAR NYELVŰ ÖSSZEFOGLALÓ (HUNGARIAN SUMMARY)}

A fahéjsavat (E-3-fenilpropénsav) és származékait több mint 140 évvel ezelőtt fedezték fel, ennek ellenére a mai napig intenzíven kutatott vegyületek, köszönhetően számos felhasználási lehetőségüknek (mint az UV védelem, élelmiszerek tartósítása és ízesítése, valamint vegyipari és gyógyszeripari köztitermékek előállítása, stb.). Az említett alkalmazási lehetőségek ellenére, a heterociklusos származékaik és a megfelelő $Z$ izomerek (beleértve a 3-arilpropénsavakat és a 2,3-arilpropénsavakat) előállítására és azok alkalmazási lehetőségeire, csak alig néhány irodalmi példát találunk, így ezen vegyületek tanulmányozása még mindig időszerűnek mondható.

A jelen disszertációhoz vezető kísérleti munka során, számos $E$ és $Z$ fahéjsavat szintetizáltam, többek közt furil-, tienil-, szelenofenil- és piridil fahéjsavakat, valamint néhány $\alpha$-szubsztituált változatot, (melyek tienil-, vagy piridil gyürüt tartalmaztak) több kondenzációs reakciót felhasználva, mint a Perkin-, Kövenagel-Döbner- (melyekkel a termodinamikailag stabilabb $E$ izomer nyerhető) és különböző, Horner-WadsworthEmmons reakciókat (HWE) (ami $E$ - vagy $Z$-szelektív is lehet a reaktánstól és körülményektől függően). Az előállított vegyületeket precíz szerkezetvizsgálatnak vetettem alá, számos spektroszkópiai módszert alkalmazva, mint az infravörös spektroszkópia (IR), a mágneses magrezonancia spektroszkópia (NMR) több 1D és 2D technika felhasználásával és más analitikai eszközöket is, például Röntgen diffractometriát (XRD), atomi erő mikroszkópiát (AFM) és infravörös mikrospektroszkópiát (IRM). A kísérleti eredményeket kvantum kémiai módszerekkel is modelleztem, több különböző elméleti szinten (PM6, HF/6-31G(d,p), B3LYP/CBSB7, WB97XD/CBSB7).

A sztereokémiailag tiszta E-3-heteroaromás propénsavak előállítására, a Knövenagel-Döbner kondenzáció módisított változata (ahol elsősorban a reakció hőmérséklete, ideje és a termékek feldolgozása változik) bizonyult a legalkalmasabbnak, kiemelkedően magas termeléssel és szelektivitással (100\% E-szelektivitás és $>95 \%$ gyakorlati kitermelés). Az E- $\alpha$-szubsztituált fahéjsavak előállítására, mind a módisított Perkin, mind a HWE szintézis alkalmasnak bizonyult, azonban a HWE eljárást sokkal eredményesebbnek találtam (a reakció szelektivitása változtatható és a termelés is viszonylag magas $>90 \%$ ) mint a Perkin reakciót. A nehezen hozzáférhető Z-3heteroaromás fahéjsavak szintén előállíthatóak a HWE reakcióval, az Ando-foszfonátot 
alkalmazva. Az erősen stabilizált köztiterméknek köszönhetően (mélyhőmérsékleten, argon atmoszféra alatt) 90:10 (Z:E) szelektivitás is elérhető a termelés pedig minden esetben elfogadható mértékű (>90\%). Az UV-indukált fotoizomerizáció, megfizethető eljárásnak bizonyult a Z-izomerek előállítására, azonban az izomer keverék elválasztása speciális felszerelést igényel.

Az előállított vegyületek szerekezetképző sajátságainak vizsgálatára számos műszeres technika kombinációját alkalmaztam, a szilárd kristályos, az oldat fázis és a felületi adszorbeátumok vizsgálatára. Infravörös spektroszkópia segítségével felderítettem, hogy mind az E mind Z-fahéjsav (3- és 2,3-arilpropénsavak) származékok, melyek fenil, vagy öttagú heteroaromás gyűrűt tartalmaznak, a karboxil csoportok közt kialakuló, ciklusos kettős hidrogénhiddal összetarott dimereket alkotnak, szilárd fázisban és oldatban , amennyiben az oldószer aprotikus (kloroform vagy DMSO). Ettől, cask a piridil fahéjsavak mutatnak eltérést, ahol szilárd fázisban sz ikerionos szerkezet dominál. Ennek ellenére bebizonyosodott, hogy DMSO-ban lehetséges a hidrogenhíddal összetartott dimerek képződése. Az infravörös spektroszkópiával nyert eredményeket összehasonlítva (melyeket különböző fázisban rögzítettem) a gyengébb (aromás)C-H...X(aromás)(X = O, S, N, Se), ill. az olefins protonok és a karboxil csoport oxigénje közt kialakuló másodlagos hidrogénhidak jelenléte is valószínűsíthető, melyre az aromás rezgések szisztematikus eltolódásából lehet következtetni.

A telített DMSO oldatban rögzített ${ }^{1} \mathrm{H}-1{ }^{1} \mathrm{H}$ korrelációs spektrumok (COSY) azt bizonyították, hogy az előbb említett másodrendű hidrogénhidak valóban léteznek, különös tekintettel az aromás gyűrűk közt kialakuló kölcsönhatásra, ahol számos intermolekuláris kölcsönhatást fedeztem fel, nem szomszédos protonok közti csatolások révén, melyek átlón kívüli csatolások formájában jelennek meg a spektrumon. Egy, a hidrogénhidak jelenlétének további jelét is megfigyeltem: az aromás protonok jelszélesedésének formájában, ami sokkal jelentősebb mértékű volt, mint az olefins protonok jelszélesedése. Ez a jelenség azt bizonyítja,a hogy az olefins protonokkal kialakuló hidrogénhidak szerepe az oldat fázisban nem meghatározó. Az ${ }^{1} \mathrm{H}-{ }^{1} \mathrm{H}$ nukleáris Overhauser effektus spektroszkópia(NOESY) alkalmasnak bizonyult a tanulmányozott vegyületek konformációs állapotainak felderítésére. Az eredmények azt mutatták, hogy a 3-heteroaromás származékok gyűrűi, híg oldatban (0.05 M in DMSO) szabadon forognak, azonban a 2,3-szubsztituált változatoknál eltérő volt a tapasztalat. A 2. Szénatomon 
található gyưrű viszonyla szabadon foroghat, míg a másik gyűrű konformációs tere valamelyest gátolt.

Az önszerveződő képességet polikristályos fémfelületeken is vizsgáltam (PLD technikával készült arany és ezüst felületeken) a dip-coating eljárást alkalmazva, 0,1 Mos kloroformos oldatokat alkalmazva. Az elkészült molekuláris rétegeket az IRM és az AFM technikák kombinációjával tanulmányoztam. Az IRM mérések eredményei igazolták, hogy a molekulák felületen történő megkötése sikeres volt. A adszorbeált rétegekről készült AFM felvételek, számos érdekes, magasabb rendű formációt fedtek fel, ahol a rétegvastagság minden esetben nagyobb volt, mint monomolekulás borítottság esetén. Tehát az említett hidrogénhidas kölcsönhatások jelenléte meghatározónak bizonyult. A felületen megtalálható, igen nagy méretű anyagcsúcsok a $\pi$-stacking kölcsönhatás jelenlétét is valószínűsítik.

A konformáció analízis sikeresen felderítette a heteroaromás fahéjsav származékok potenciálfelületét, és az $\alpha$-szubsztituált változatok stabil konformereit. A konformációs terek tulajdonságai teljes egyezést mutattak a NOESY mérések eredményével. Ezt követően a legstabilabb konformereket (melyek a konformáció analízis legkisebb energiájú szerkezetei) magasabb elméleti szinten optimalizáltam, és a heteroaromás fahéjsavakra minden esetben teljesen sík szerkezetet kaptam, az $\alpha$ szubsztituált származékokra viszont csavart geometriákat. A kettős hidrogénhíddal összetartott dimerekre számolt geometriai adatok és kötési energiák bizonyították, hogy a domináns szerkezeti egység a dimer, átlagosan $15 \mathrm{kcal} / \mathrm{mol}$ kötési energiával. Ez az eredmény igen jól korrelál az IR mérések eredményeivel. A molekulák között kialakuló másodrendű kötőerők lehetséges erősségi sorrendjét is sikeresen meghatároztam: $\mathrm{C}-\mathrm{H} . . . \mathrm{N}>\mathrm{C}-\mathrm{H} . . . \mathrm{O}>\mathrm{C}-\mathrm{H} . . . \mathrm{S} \sim \pi-\pi>\mathrm{C}-\mathrm{H}$...Se, mely igen nagy hasonlóságot mutat a kísérleti eredményekkel.

A felsorolt eredmények egyértelműen azt mutatják, hogy a heteroaromás fahéjsavak igen sokoldalú vegyületek. Kiterjedt hidrogénhidas rendszereket képeznek minden tanulmányozott fázisban. A már említett felhasználási lehetőségek mellett, a vizsgált származékoknak számos felhasználási lehetősége adódhat az elektronika és a korrózióvédelem területén, köszönhetően a fémfelületeken mutatott viselkedésüknek. Mindemellett számos élettani hatásuk is lehetséges, mely érdekes célponttá teszi őket a gyógyszeripar számára. 


\section{ACKNOWLEDGEMENT}

Firstly, let me gratefully acknowledge the immense support and help of my supervisor Dr. István Pálinkó, my consultant Dr. Pál Sipos and Dr. Gábor Peintler for the useful suggestions. My grateful thanks go to them for both the theoretical and practical encouragement and teaching I have received from them during the years I have spent in their research group. Let me also gratefully acknowledge the efforts of my colleagues: Éva Bajnóczi, Dr. Mónika Ádok, Eszter Czeglédi, Gábor Varga, Attila Gácsi, Zsolt Ferenc, Dr. Attila Pallagi and Gábor Kozma for their help and suggestions about various problems appearing during my work. Many thanks, to all members of the Material and Solution Structure Research Group. I thank to all who helped me in any aspects in- and outside the University of Szeged, especially for Kai Ruusuvuori from the University of Helsinki for his help with the computational part of this work. Many thanks to my family and friends for the tremendous support they gave me in the last years. Finally, I would like to acknowledge the most important person in my life - my companion, who always supports me, and I especially want to gratefully thank for her patience during the last part of my PhD work. 


\section{APPENDIX}

Description and preparation of the applied materials:

Reagents:

- Selenophene 97\% (Sigma-Aldrich, UWFP) 46

- $\boldsymbol{N}, \boldsymbol{N}^{\prime}$-dimethylformamide (DMF) $>99.8 \%$ (Merck, stored over $3 \AA$ molecular sieves) 56

- Phosphorus oxychloride ( $\mathrm{POCl}_{3}$ ) 99\% (Reagentplus ${ }^{\circledR}$, Sigma-Aldrich, UWFP)

- Sodium acetate (NaOAc) 99\% (Sigma-Aldrich, UWFP) 51

- Acetic anhydride ( $\left.\mathbf{A c}_{2} \mathbf{0}\right)$ 95\% (RPL, distilled before use) 8

- Potassium carbonate $\left(\mathrm{K}_{2} \mathrm{CO}_{3}\right)$ 99\% (Reanal, UWFP)

- Hydrogen chloride (HCl) 37\% (VWR, Ph.Eur.)

- Sodium hydroxide (NaOH) (VWR, a.r. grade, used as $10 \%$ solution in water)

- Potassium hydroxide (KOH) 90\% (Molar, reagent grade, UWFP)

- Sodium in mineral oils $97 \%$ (Merck, rinsed with water-free n-hexane and handled under argon atmosphere, reagent grade)

- Ethyl acetate (EtOAc) 99.5\% (Fluka, stored over sicc. $\mathrm{K}_{2} \mathrm{CO}_{3}$ )

- Oxalyc acid ((COOH) $\left.)_{2} \times \mathbf{2} \mathbf{H}_{2} \mathbf{0}\right)$ 99\% (VWR, used in anhydrous form, dried with azeotropic distillation with benzene)

- Diethyl malonate 98\% (GC) (prepared from anhydrous oxalic acid via Fischer esterification with EtOH)19

- Piperidine 99\% (Reanal, stored over KOH flakes) 20

- Tetrabutyl ammonium bromide (TBAB): 98\% (BDH, UWFP) 53

- Pyridine 99\% (Sigma-Aldrich, ACS reagent ${ }^{\circledR}$, stored over $\mathrm{NaOH}$ pellets) 43

- 1,4-hydroquinone 99\% (Merck, UWFP) 54

- Malonic acid 99\% (VWR, UWFP) 22

- Each aromatic aldehyde was vacuum-distilled before use.

- Benzaldehyde 99\% (Reagentplus ${ }^{\circledR}$, Sigma-Aldrich) 7

- 2-furancarboxaldehyde (furfural) 99\% (ACS reagent ${ }^{\circledR}$, Sigma-Aldrich) 85

- 3-furanecarboxaldehyde 97\% (Sigma-Aldrich) 86

- 2-pyridinecarboxaldehyde 99\% (Sigma-Aldrich) 87

- 3-pyridinecarboxaldehyde 98\% (Sigma-Aldrich) 88 
- 4-pyridinecarboxaldehyde 97\% (Sigma-Aldrich) 89

- 2-thiophenecarboxaldehyde 98\% (Sigma-Aldrich) 90

- 3-thiophenecarboxaldehyde 98\% (Sigma-Aldrich) 91

- 1-Octanol 99\% (Sigma-Aldrich, reagent grade, UWFP) 57

- 4-dimethylaminopyridine (DMAP) 99\% (Sigma-Aldrich, UWFP) 59

- Triethylamine (TEA) 99\% (Sigma-Aldrich, stored over $\mathrm{NaOH}$ pellets)

- Bromine (Br2) 99\% (Sigma-Aldrich, used as $10 \mathrm{M}$ solution in dichloromethane)

- Sulfuric acid $\left(\mathrm{H}_{2} \mathrm{SO}_{4}\right)$ 98\% (VWR, UWFP)

- Palladium chloride ( $\left.\mathbf{P d C l}_{2}\right)$ 99\% (Reanal, at., UWFP)

- Lead acetate (Pb(OAc)2) 99\% (Reanal, used as 7\% aqueous solution)

- Formic acid (HCOOH) 99\% (Fluka, freshly distilled before use)

- Calcium chloride ( $\left.\mathbf{C a C l}_{2}\right)$ 96\% (Reanal, anhydrous, granulated, UWFP)

- Sodium carbonate $\left(\mathrm{NaCO}_{3}\right)$ 99\% (Fluka, used as $20 \%$ aqueous solution)

- Barium hydroxide $\left(\mathrm{Ba}(\mathbf{O H})_{2} \times \mathbf{8} \mathbf{H}_{2} \mathbf{O}\right)$ 98\% (Reanal, used as $0.8 \mathrm{M}$ aqueous solution)

- Calcium carbonate $\left(\mathrm{CaCO}_{3}\right)$ purity was not checked, (prepared via the precipitation of $\mathrm{CaCl}_{2}$ with $\mathrm{Na}_{2} \mathrm{CO}_{3}$ ).

- Barium sulfate (BaSO4) purity was not checked, (prepared via the precipitation of $\mathrm{Ba}(\mathrm{OH})_{2}$ with $\left.\mathrm{H}_{2} \mathrm{SO}_{4}\right)$.

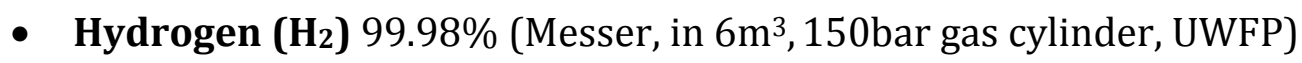

- Quinoline (2,3-benzopyridine) 98\% (Reachim, used after vacuum distillation) 27

- 3,6-dithia-1,8-octanediol 98\% (Sigma-Aldrich, UWFP) 28

- Chloroacetic acid 97\% (Reachim, UWFP)

- Methyl chloroacetate 99\% (GC) (prepared via Fischer esterification of chloroacetic acid with $\mathrm{MeOH}) 62$

- Sodium Iodide (NaI) 99\% (Reanal, anhydrous, dried at $120^{\circ} \mathrm{C}$ )

- $\quad$ Trimethyl phosphite (P(OMe)3) 97\% (Sigma-Aldrich, UWFP) 65

- Iodine 99.5\% (Merck, reagent grade, UWFP)

- Sodium thiosulfate $\left(\mathrm{Na}_{2} \mathbf{S}_{2} \mathbf{O}_{3} \times \mathbf{5} \mathbf{H}_{2} \mathbf{O}\right)$ 98\% (VWR, UWFP)

- $\quad$ Trimethylsilyl chloride (TMSCl) 99\% (Sigma-Aldrich, UWFP) 66 
- Oxalyl chloride ((COCl)2) 95\% (GC) (prepared via the halogenation of anhydrous oxalic acid with $\left.\mathrm{PCl}_{5}\right) 68$

- Phosphorus pentachloride (PCl 5$)$ 95\% (Fluka, UWFP)

- 2,2,2-Trifluoroethanol 99\% (Sigma-Aldrich, Reagentplus ${ }^{\circledR}$, UWFP) 70

- O-cresol 99\% (Sigma-Aldrich, Reagentplus ${ }^{\circledR}$, UWFP) 71

- Potassium in mineral oils 95\% (Merck, rinsed with water-free hexane and handled under argon atmosphere, reagent grade)

- $\quad \boldsymbol{t}$-Butanol 99\% (Reanal, stored over sicc. $\mathrm{MgSO}_{4}$ )

- Potassium t-butoxide $(\boldsymbol{t}$-BuOK) purity was not checked, (prepared via the reaction of potassium with t-butanol) 72

- Potassium bis-trimethylsilylamide (KHMDS) 95\% (Sigma-Aldrich, stored under argon atmosphere) 32

- 18-crown-6 (complexone) 99\% (Sigma-Aldrich, UWFP) 31

- Sodium hydride (NaH) 95\% (Sigma-Aldrich, dry, stored under argon atmosphere at $-20^{\circ} \mathrm{C}$ )

- Phenylacetic acid 99\% (Sigma-Aldrich, UWFP) 17

- Potassium cyanide 96\% (Reanal, UWFP)

- Red phosphorous 97\% (Sigma-Aldrich, UWFP)

- Phosphorus tribromide* $98 \%$ (GC) (prepared via the halogenation of red phosphorous with bromine)

Supporting materials:

- Sodium hydrogencarbonate $\left(\mathrm{NaHCO}_{3}\right)$ 99.7\% (Sigma-Aldrich, Reagentplus ${ }^{\circledR}$, used as $20 \%$ aqueous solution)

- Sodium chloride (NaCl) 99.9\% (Reanal, a.p., used as saturated aqueous solution)

- Ammonium chloride (NH4Cl) 99\% (Reanal, used as 10\% aqueous solution)

- Sodium sulfate ( $\left.\mathrm{Na}_{2} \mathrm{SO}_{4}\right)$ 99\% (Fluka, anhydrous, UWFP)

- Magnesium sulfate (MgSO 4 ) 98\% (Reanal, anhydrous, UWFP)

- Benzophenone 99\% (Fluka, UWFP)

- 3 Å molecular sieves (Sigma-Aldrich, $1.6 \mathrm{~mm}$ beads, regenerated at $300^{\circ} \mathrm{C}$ )

- 4 Å molecular sieves (Fluka, rods, regenerated at $300^{\circ} \mathrm{C}$ )

- Silica gel: Normasil $60(43-63 \mu \mathrm{m})(V W R$, for column chromatography) 
- Silicagel on TLC Al foils 60 Å (Sigma-Aldrich, with fluorescent indicator)

Solvents:

- Methanol (MeOH) 99.9\% (Sigma-Aldrich, Reagentplus ${ }^{\circledR}$, UWFP)

- Ethanol (EtOH) 99.8\% (VWR, anhydrous, stored over $3 \AA$ molecular sieves)

- Tetrahydrofuran (THF) 99.9\% (VWR, anhydrous, stored over Na/benzophenone, distilled from $\mathrm{NaH}$ before use)

- Ethyl acetate (EtOAc) 99.9\% (Sigma-Aldrich, Chromasolv ${ }^{\circledR}$, HPLC grade) 51

- Acetone 99\% (VWR, UWFP) 63

- Chloroform ( $\mathbf{C H C l}_{3}$ ) 99\% (Sigma-Aldrich, contains 1\% ethanol as stabilizer)

- Dichloromethane $\left(\mathbf{C H}_{2} \mathbf{C l}_{2}\right) \mathbf{9 9 . 5 \%}$ (Sigma-Aldrich, contains 0.5\% amylene as stabilizer, stored over sicc. $\mathrm{CaCl}_{2}$ )

- Chlorobenzene 99\% (Fluka, stored over sicc. $\left.\mathrm{CaCl}_{2}\right) \mathbf{5 5}$

- n-hexane 96\% (Sigma-Aldrich, anhydrous, UWFP)

- Benzene 99\% (Merck, stored over sodium wire)

- o-Xylene 99\% (Merck, puriss, stored over sodium wire) 52

- Diethyl ether 99\% (VWR, stored over sodium wire)

- DMSO (dimethyl sulfoxide) 99.8\% (Merck, spectroscopic grade)

The $\mathrm{C}$ source code of the driving unit of the UV-flow reactor:

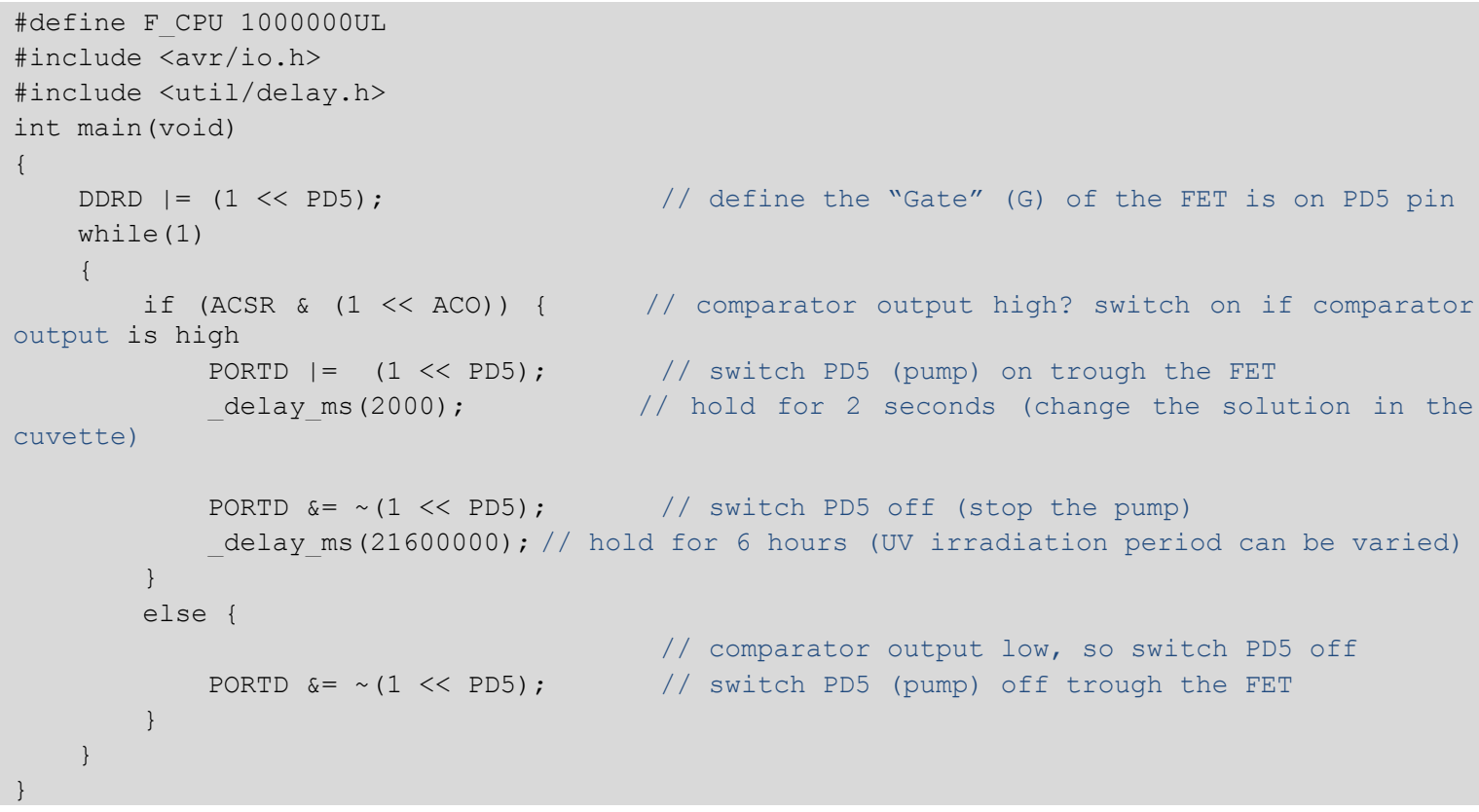




\section{The simplified standalone (AutoHotKey) source code of Quantum Hyppo (demo), without the GUI section:}

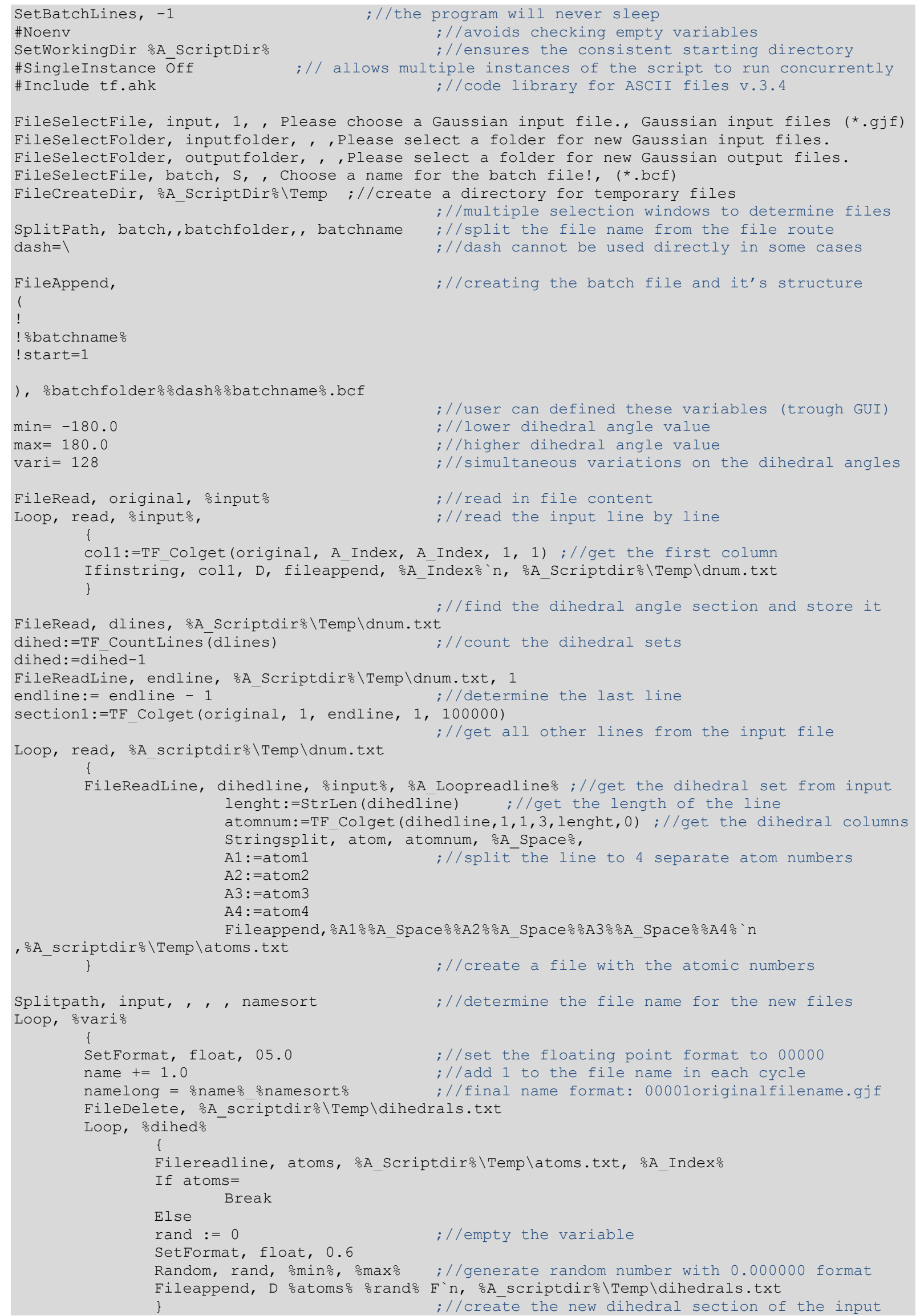


Fileread, dihedrals, $\% A$ scriptdir\% $\$ Temp \dihedrals.txt

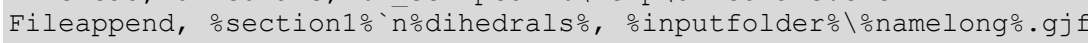

extin=.gjf

;//merge the file parts and create the input new file

extout $=$.out

infile:=inputfolder dash namelong extin

outfile:=outputfolder dash namelong extout

separator=, $\quad$ ///add the route of the input and output files to the batch file

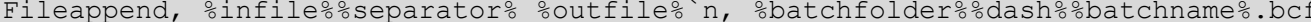
\}

FileDelete, A scriptdiro $\backslash$ Temp \dihedrals.txt

;//delete temporary files

FileDelete, A Scriptdir\%\Templatoms.txt

FileDelete, $\% A$ Scriptdir\% $\backslash$ Temp \dnum.txt

Msgbox, 4160, Finished!, All desired files were created. ;//finish message

Return

://close the program

\section{The simplified standalone (AutoHotKey) source code of Quantum Hyppo (demo), without the GUI section:}

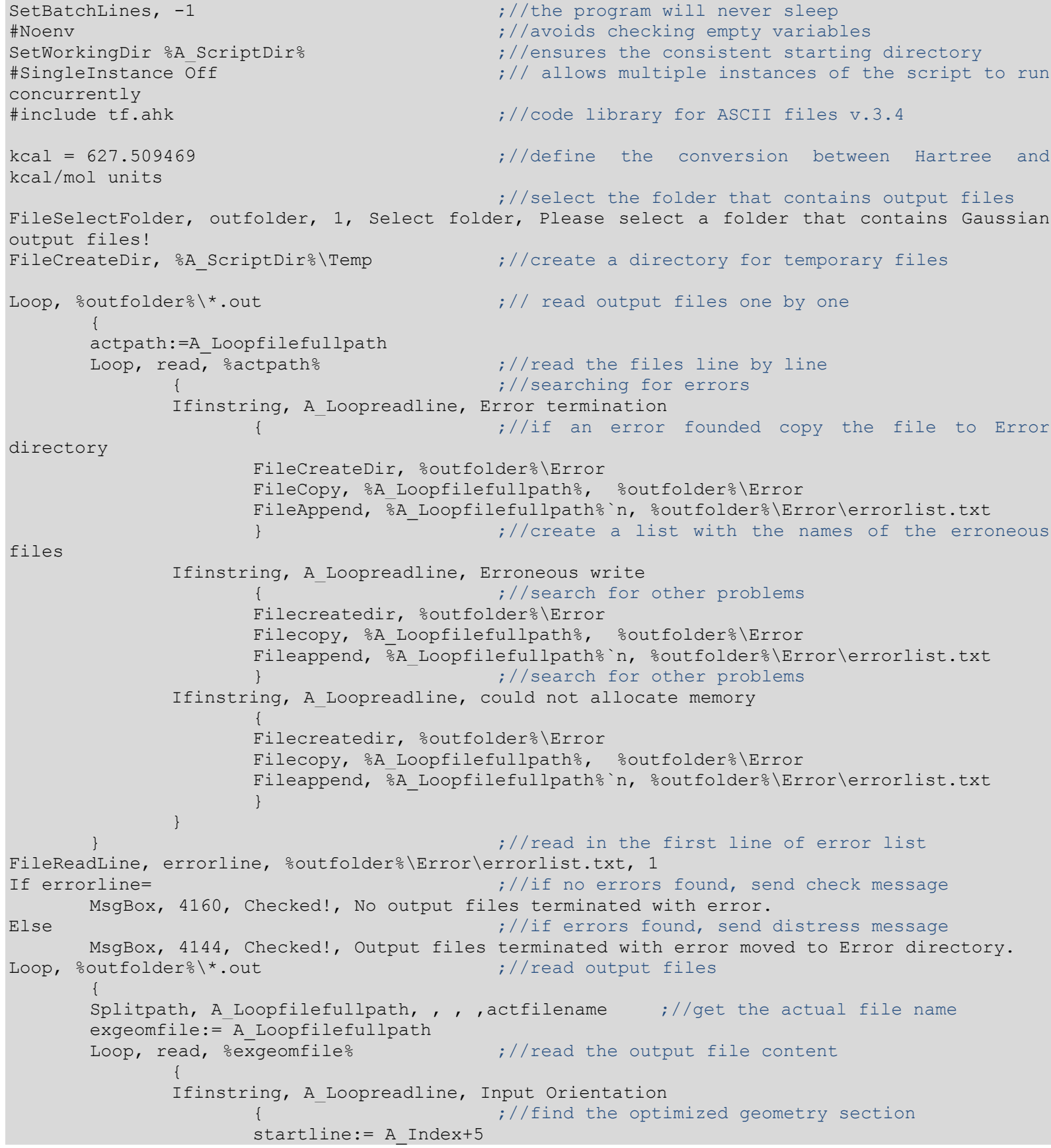




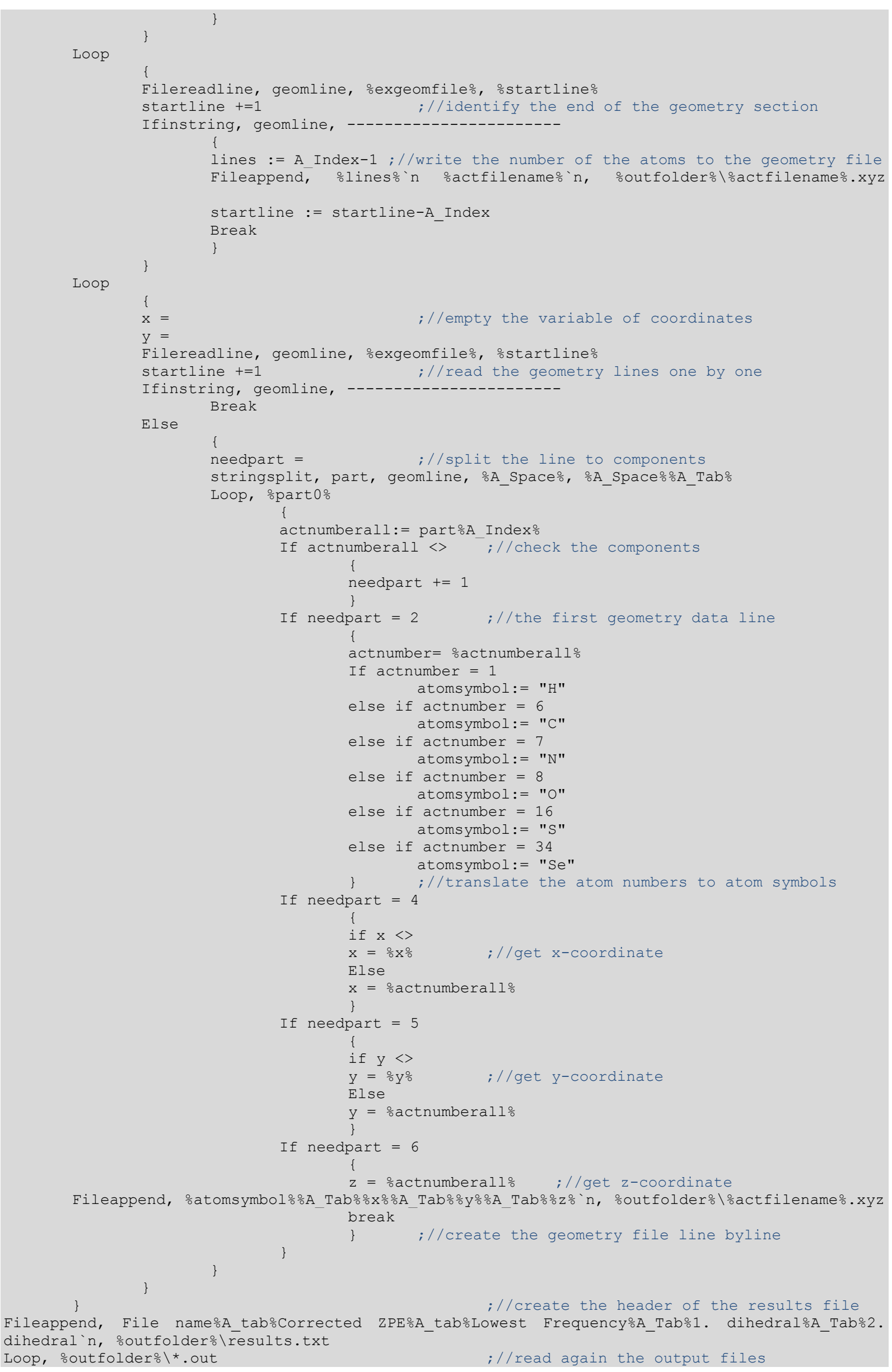




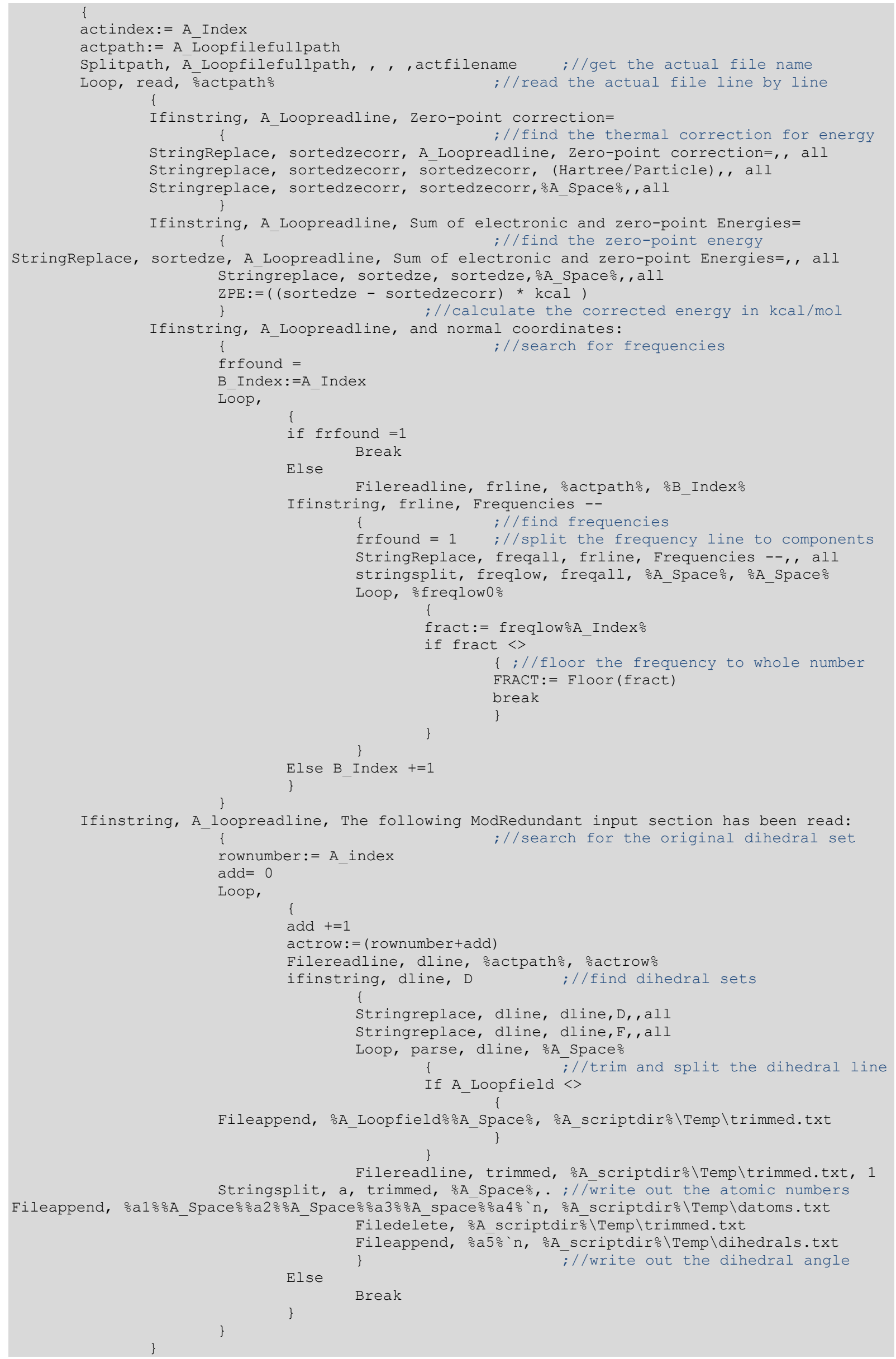


FileReadLine, d1, $\%$ A scriptdir $\$ Templdatoms.txt, 1 ;//read in dihedral components

FileReadLine, d2, A A scriptdir\%\Temp\datoms.txt, 2

FileReadLine, a1, 으 scriptdiro \Temp\dihedrals.txt, 1

FileReadLine, a2, \%A scriptdirotTemp\dihedrals.txt, 2

\section{Fileappend,}

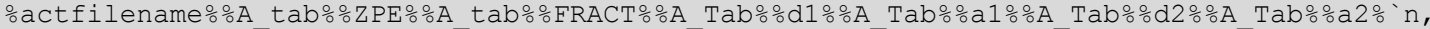

outfoldero\results.txt

FileDelete, A scriptdiro\Templdatoms.txt ;//create the results file with several data FileDelete, A scriptdir\% $\backslash$ Temp\dihedrals.txt \}

MsgBox, 4160, Finished!, All desired data were extracted. ;//finish message Return 